\title{
Late Quaternary vegetation, climate and fire dynamics in the Podocarpus National Park region, southeastern Ecuadorian Andes
}

\author{
Dissertation \\ zur Erlangung des mathematisch-naturwissenschaftlichen Doktorgrades \\ "Doctor rerum naturalium" \\ der Georg-August-Universität Göttingen
}

vorgelegt von

Diplomgeologe

Holger Niemann

aus

Bremen

Göttingen 2008

Referent: Prof. Dr. Hermann Behling

Korreferent: Prof. Dr. Michael Kessler

Weitere Referentinnen/ Referenten: Prof. Dr. Erwin Bergmeier, Prof. Dr. Gerhard Gerold Prof. Dr. Beate Michalzik, Dr. Markus Hauck

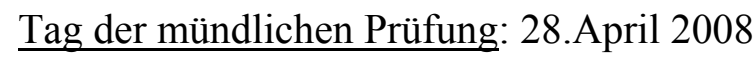




\section{Table of contents}

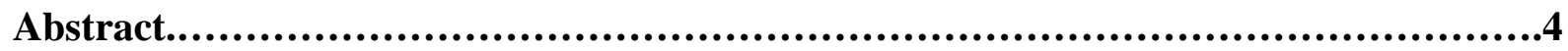

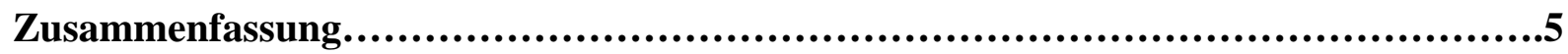

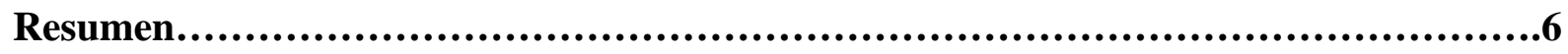

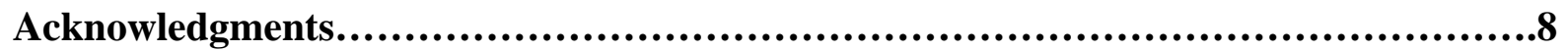

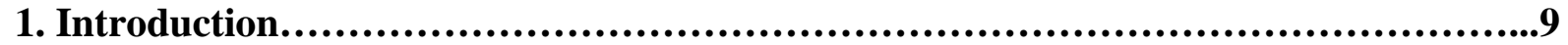

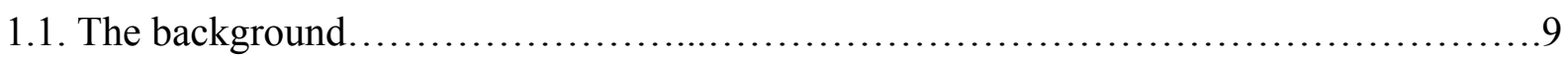

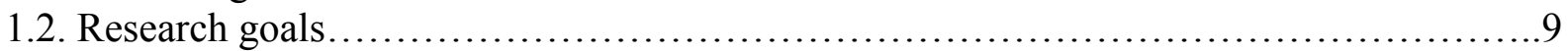

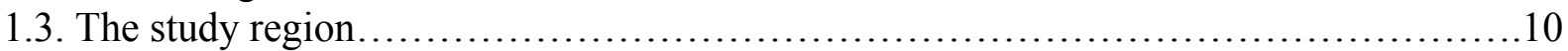

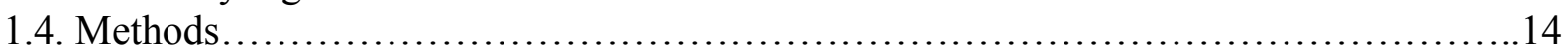

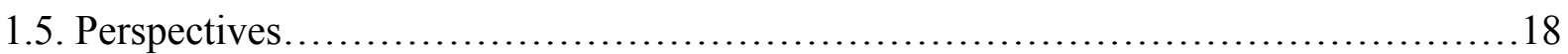

2. Recent vegetation/modern pollen rain relationship studies on an altitudinal transect of mountain forest and paramo vegetation in the southeastern Ecuadorian Andes.........19

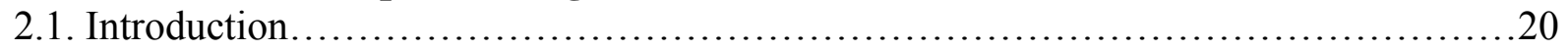

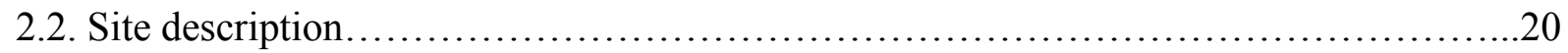

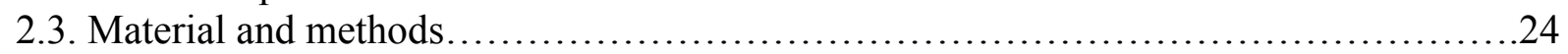

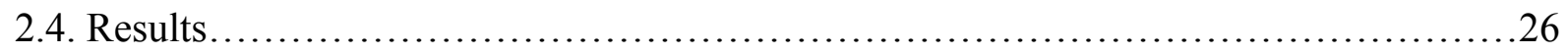

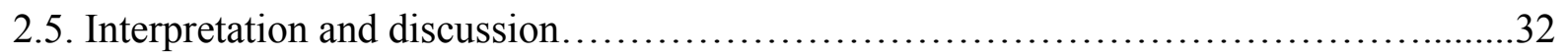

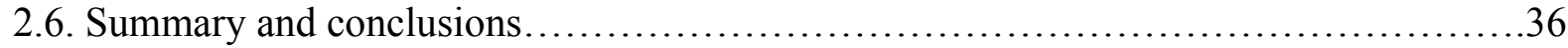

3. Late Holocene environmental change and human impact inferred from three soil monoliths and the Laguna Zurita multi-proxi record in the southeastern Ecuadorian

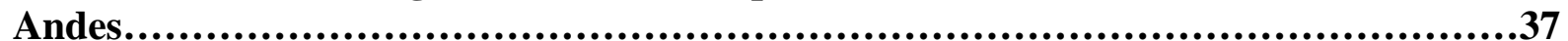

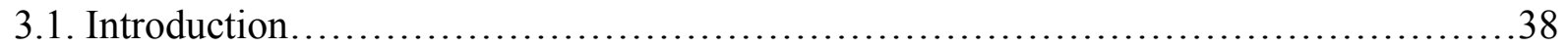

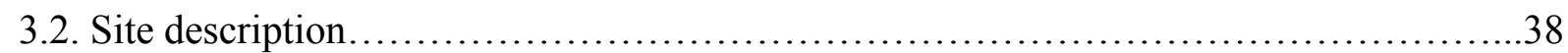

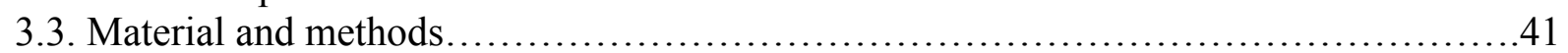

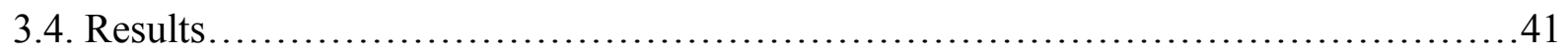

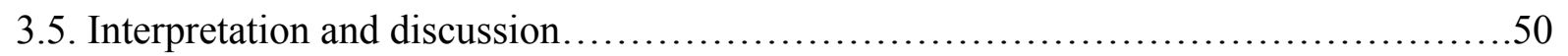

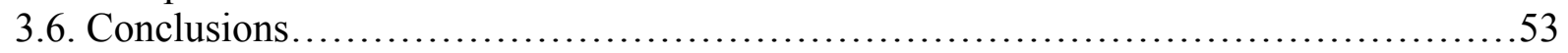

4. Holocene vegetation, climate and fire dynamics inferred from the (11,700 cal yr BP) Laguna Rabadilla de Vaca multi-proxy record in the southeastern Ecuadorian Andes......................................................................................54

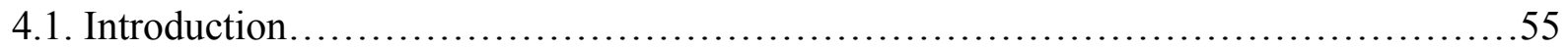

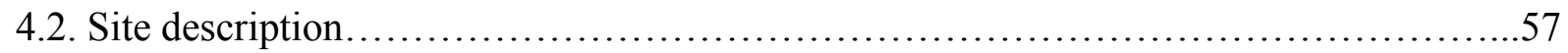

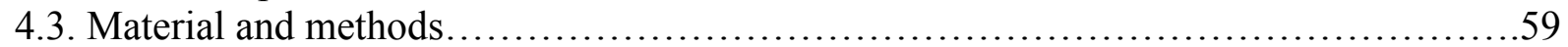

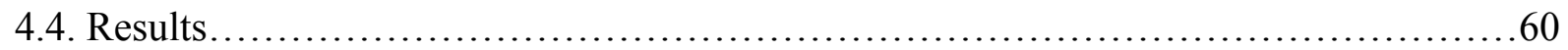

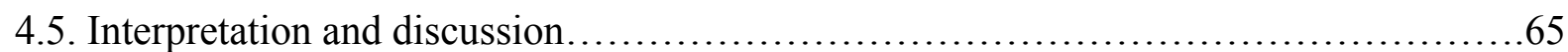

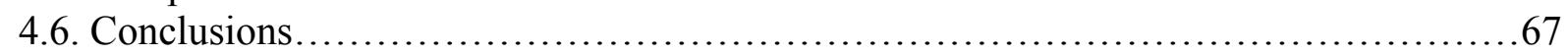

5. Late Pleistocene and Holocene vegetation development, climate variability and human impact inferred from Cocha Caranga multi-proxy records in the southeastern Ecuadorian Andes.........................................................................69

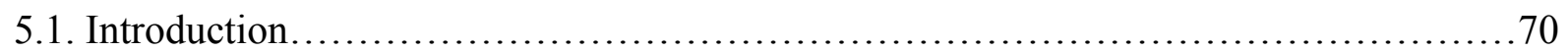

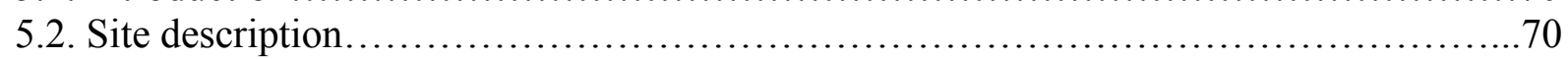




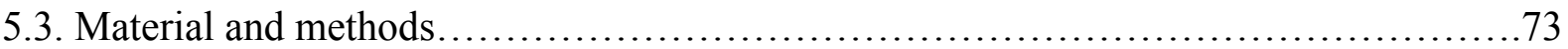

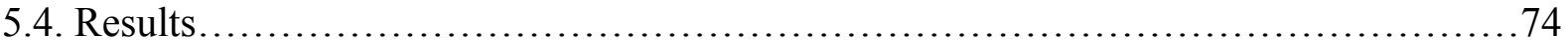

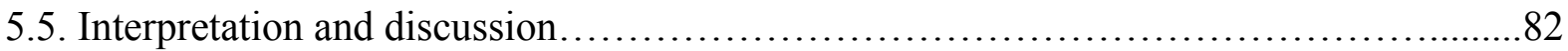

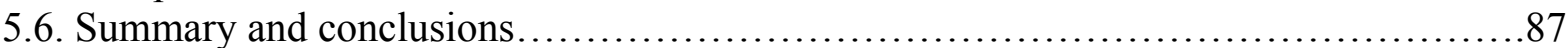

6. Late Quaternary vegetation, climate and fire dynamics inferred from the El Tiro record in the southeastern Ecuadorian Andes.............................................88

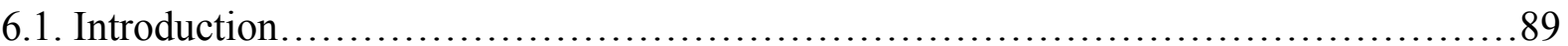

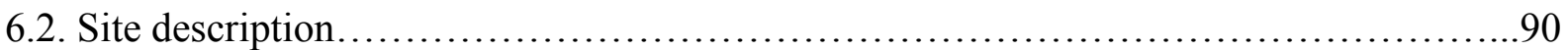

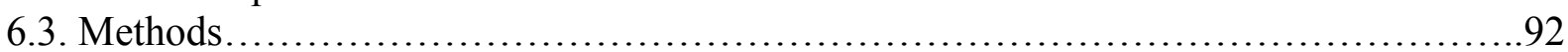

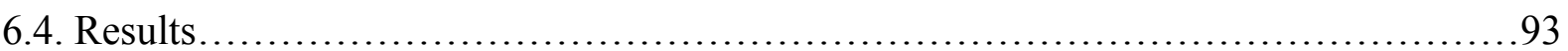

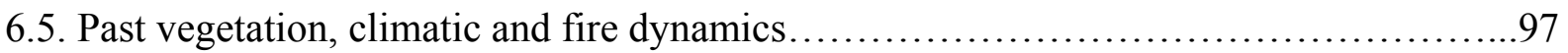

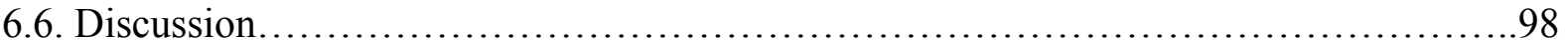

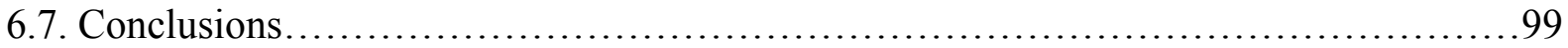

7. Supplementary studies.................................................................101

7.1. Sub recent pollen data in comparison with recent vegetation/modern pollen rain transect data on the altitudinal gradient from the Podocarpus National Park area......................101 7.2. Human impact, inferred from a prehistoric terrace in the upper Rio San Francisco valley,

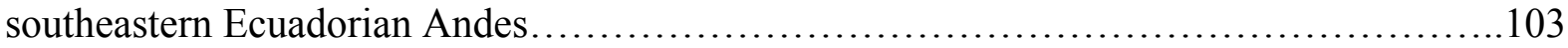

8. Summary and Conclusions..............................................................106 8.1. Recent vegetation/modern pollen rain studies on the altitudinal gradient in comparison with sub recent pollen data, in the Podocarpus National Park region........................ 106 8.2. Late Quaternary vegetation, climate and fire dynamic in the Podocarpus National Park

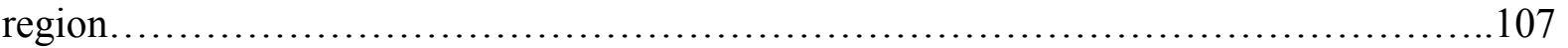

8.3. Human impact in the Podocarpus National Park region during the past.................108

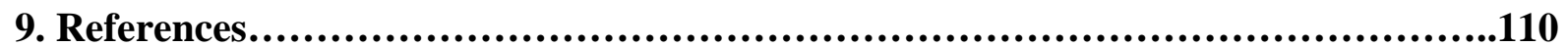

Appendix A - Identified pollen and spore types.....................................116

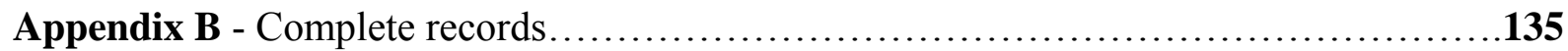




\section{Abstract}

In order to study the stability and dynamics of highly biodiverse mountain rain forest and paramo ecosystems, the late Pleistocene and Holocene climate and fire variability, as well as human impact in the Podocarpus National Park region, the first comprehensive palaeoenvironmental study from the southeastern Ecuadorian Andes is presented.

An initial study of recent vegetation/modern pollen rain relationship on an altitudinal transects between 1800 and $3200 \mathrm{~m}$ elevation in the mountain forest and (sub)-paramo vegetation of the ECSF (Estacion Cientifica San Francisco) research area provide important background information in the interpretation of late Quaternary pollen records. Cluster analysis on the pollen rain data, provided by CONISS, clearly reflects the zonation of the different vegetation units, lower mountain forest (LMF), upper mountain forest (UMF) and (sub)-paramo. A relatively high number of pollen taxa correspond to the altitudinal distribution of genera and families of modern vegetation. The modern tree line in the research area is at ca. $2790 \mathrm{~m}$, which is pointed out by an increase of (sub)-paramo taxa and a decrease of mountain forest taxa in the pollen rain data.

Palaeoenvironmental changes, inferred from 9 lake, peat bog and soil deposits, collected at different elevations between ca. 2000 and $3300 \mathrm{~m}$, were investigated by pollen, spores and charcoal analysis, in combination with XRF data and magnetic susceptibility scanning on the lake sediment cores.

During the late Pleistocene from ca. 21,000 to 11,200 cal yr BP, grass-paramo vegetation occurred at the El Tiro-Pass $(2810 \mathrm{~m})$, reflecting cold and moist climatic conditions, as well as a shift of vegetation zones into lower elevation during this period. During the transition from late Pleistocene to early Holocene from ca. 14,500 to 9700 cal yr BP, arboreal taxa, mainly Weinmannia strongly increased at Laguna Cocha Caranga $(2710 \mathrm{~m})$, reflecting a raise in temperature. The early Holocene from ca. 11,200 to 8900 cal yr BP (El Tiro-Pass) is characterised by an increase of temperature and moisture, as well as a shift of vegetation zones into higher elevation. During the mid Holocene period, from ca. 8900 to $3300 \mathrm{cal} \mathrm{yr}$ $\mathrm{BP}$, upper mountain forest vegetation developed at the El Tiro-Pass, where subparamo vegetation occurred in recent times, suggesting a warmer climate than present day at this elevation. XRF-scanning data from Laguna Rabadilla de Vaca $(3310 \mathrm{~m})$ reflects a drier period from ca. 8990 to $6380 \mathrm{cal} \mathrm{yr} \mathrm{BP}$ and a wetter period from ca. 6380 to $3680 \mathrm{cal} \mathrm{yr} \mathrm{BP}$. The green algae Botryococcus braunii, Isoetes and Cyperaceae were used to reconstruct Holocene wet/dry phases at Laguna Cocha Caranga. Drier climatic conditions occurred from ca. 9700 to $6900 \mathrm{cal} \mathrm{yr} \mathrm{BP}$ and from ca. 4200 to $1300 \mathrm{cal} \mathrm{yr} \mathrm{BP.} \mathrm{From} \mathrm{ca.} 6900$ to $4200 \mathrm{cal} \mathrm{yr} \mathrm{BP}$ and from ca. 1300 cal yr BP to modern times wetter climatic conditions occurred.

During the late Holocene, modern climatic conditions, as well as recent vegetation established since ca. 3680 cal yr BP at Laguna Rabadilla de Vaca and since ca. 3300 cal yr BP at the El Tiro-Pass.

An increase of fire intensity during the early to mid Holocene period after ca. $9700 \mathrm{cal} \mathrm{yr}$ $\mathrm{BP}$ at Laguna Cocha Caranga and after about $7500 \mathrm{cal}$ yr BP at the El Tiro-Pass reflects the beginning of human impact on the ecosystem in the Podocarpus National Park region. High values of grasses documents that past fires have markedly influenced the floristic composition of the mountain rain forest and paramo ecosystems during the mid to late Holocene period. The reduction of fire intensity coupled with a decrease of grasses after ca. 1300 cal yr BP (Laguna Cocha Caranga) and between ca. 970 to 400 cal yr BP (Upper Rio San Francisco valley), coupled with a missing of Zea mays pollen, suggests a reduction and/or absence of human activities, may be as a result of political unrest. After the reduction and/or absence of human influence the mountain forest vegetation starts to recover. 


\section{Zusammenfassung}

Die Sensibilität hochgradig artenreicher Bergregenwald- und Paramoökosysteme, die spätpleistozäne- und holozäne Klima- und Feuerdynamik, sowie der menschliche Einfluss auf die Ökosysteme in der Podocarpus Nationalpark Region, stehen im Focus dieser ersten umfassenden Studie aus den südöstlichen Anden Ecuadors.

Das Verhältnis zwischen rezenter Vegetation und aktuellem Pollenniederschlag auf einem Höhengradienten zwischen 1800 und $3200 \mathrm{~m}$ in der Bergregenwald- und (Sub)-Paramozone, im ECSF (Estacion Cientifica San Francisco) Stationswald, bilden eine wichtige Grundlage für die Interpretation fossiler Pollendaten. Cluster-Analysen (CONISS) auf Grundlage der Daten des Pollenmonitoring spiegeln die unterschiedlichen Vegetationszonen unterer Bergregenwald (LMF), oberer Bergregenwald (UMF) und (Sub)-Paramo im Pollenniederschlag deutlich wider. Eine relativ hohe Anzahl der Pollen Taxa korrespondieren mit dem Verteilungsmuster von Genera und Familien der rezenten Vegetation auf dem Höhengradienten. Die Zunahme von (Sub)-Paramo Pollen und ein Rückgang von Bergregenwald Pollen reflektieren die aktuelle Waldgrenze bei ca. $2790 \mathrm{~m}$.

Paläoumweltveränderungen, basierend auf der Untersuchung von 9 See-, Moor- und Bodenbohrkernen aus verschiedenen Höhenlagen zwischen ca. 2000 und 3300 m, konnten anhand von Pollen-, Sporen- und Holzkohleanalyse in Kombination mit XRF Daten und Magnetic Susceptibility Scanning (Seesedimente), rekonstruiert werden.

Während des späten Pleistozäns, in der Zeit von ca. 21,000 bis 11,200 cal yr BP, herrschte ein kalt-feuchtes Klima am El Tiro-Pass $(2810 \mathrm{~m})$ vor. Die Vegetationszonen waren abgesunken, Gras-Paramo Vegetation hatte sich dort ausgebreitet, wo heutzutage Subparamo Vegetation anzutreffen ist. Der Anstieg des Baumpollenanteils, vorwiegend Weinmannia, im Pollendiagramm von Laguna Cocha Caranga $(2710 \mathrm{~m})$, reflektiert eine Zunahme der Temperatur während des Überganges vom späten Pleistozän zum Holozän (ca. 14,500-9700 cal yr BP). Das frühe Holozän von ca. 11,200 bis 8900 cal yr BP (El Tiro-Pass) ist charakterisiert durch einen Anstieg von Temperatur und Niederschlag sowie einer Aufwärtsbewegung der Vegetationszonen. Im mittleren Holozän von ca. 8900 bis 3300 cal yr BP breitete sich am El Tiro-Pass oberer Bergregenwald aus, es kann von höheren Temperaturen als heutzutage ausgegangen werden. XRF-Scanningdaten des Sedimentkerns von Laguna Rabadilla de Vaca $(3310 \mathrm{~m})$ belegen eine trockenere Phase von ca. 8990 bis 6380 cal yr BP und eine feuchtere Phase von ca. 6380 bis 3680 cal yr BP. Mittels Botryococcus braunii, Isoetes und Cyperaceae konnten Holozäne Klimaphasen (feucht/trocken) für die Lokalität Laguna Cocha Caranga rekonstruiert werden. Trockenere klimatische Verhältnisse herrschten in der Zeit von ca. 9700 bis 6900 cal yr BP und von ca. 4200 bis 1300 cal yr BP vor. Von ca. 6900 bis $4200 \mathrm{cal} \mathrm{yr} \mathrm{BP} \mathrm{und} \mathrm{von} \mathrm{ca.} 1300 \mathrm{cal}$ yr BP bis heute war das Klima feuchter.

Die nahezu heutigen Klima- und Vegetationsverhältnisse etablierten sich im späten Holozän ab ca. 3680 cal yr BP (Laguna Rabadilla de Vaca) und ab ca. 3300 cal yr BP (El Tiro-Pass).

Ein starker Anstieg der Feuerintensität zu Beginn des mittleren Holozäns ab ca. 9700 cal yr BP (Laguna Cocha Caranga) und ab ca. 7500 cal yr BP (El Tiro-Pass) reflektieren den Beginn des menschlichen Einflusses auf das Ökosystem in der Podocarpus Nationalpark Region. Hohe Graspollenanteile dokumentieren den starken Einfluss von Feuern auf die floristische Zusammensetzung der Bergregenwald- und Paramoökosysteme während des mittleren und späten Holozäns. Der Rückgang der Feuerintensität sowie wesentlich geringere Graspollenanteile ab ca. 1300 cal yr BP (Laguna Cocha Caranga) und zwischen ca. 970 und 400 cal yr BP (Oberes Rio San Francisco Tal), in Verbindung mit dem Fehlen von Maispollen, dokumentieren einen Rückgang, bzw. das Fehlen menschlicher Aktivität infolge politischer Wirren. In Folge des Rückgangs oder Fehlens menschlicher Aktivität konnten sich die Bergregenwälder regenerieren. 


\section{Resumen}

Para estudiar la estabilidad y dinámica del bosque lluvioso tropical altamente biodiversos y del ecosistema páramo, la variabilidad del clima y fuego en el Pleistoceno tardío y Holoceno, así como el impacto humano en la región del Parque Nacional Podocarpus, el primer estudio paleoambiental del sudeste de los Andes ecuatorianos serán presentados.

Un estudio inicial de la relación entre la vegetación reciente y polen, en un transecto de vegetación en una gradiente altitudinal entre 1800 y 3200 m elevación en el bosque de montaña y (sub)-páramo en la Estación Científica San Francisco (ECSF), provee de importante información y antecedentes en la interpretación de registros de polen del Cuaternario tardío. Análisis cluster de los registros de polen a través de CONISS, claramente reflejan la zonificación de diferentes unidades de vegetación, Bosque montano bajo (LMF), Bosque montano alto (UMF) y sub-páramo. Un número relativamente alto de taxones de polen corresponden a la distribución altitudinal de géneros y familias de vegetación actual. El límite del bosque actual en el área de estudio esta alrededor de $2790 \mathrm{~m}$, el cual es caracterizado por taxones de (sub)-páramo y un decrecimiento de taxones de bosque de montaña en los registros de polen.

Cambios paleoambientales inferidos de 9 lagos, turberas y depósitos de suelos, colectados en diferentes elevaciones entre 2000 y 3300 m, fueron investigados a través de análisis de polen, esporas y partículas de carbón, en combinación con XRF- y escaneo de susceptibilidad magnética.

Durante el Pleistoceno tardío entre 21,000 a 11,200 cal yr BP, las condiciones climáticas eran frías y húmedas, herbazales de páramo fue el tipo de vegetación dominante en El TiroPass $(2810 \mathrm{~m})$, indicando un cambio en la vegetación hacia zonas mas bajas durante este período. Durante la transición entre el Pleistoceno tardío y el Holoceno temprano entre 14,500 y 9700 cal yr BP, taxones arbóreos principalmente Weinnmania incrementó fuertemente en la Laguna Cocha Caranga $(2710 \mathrm{~m})$, reflejando un incremento en la temperatura. Durante el Holoceno temprano entre 11,200 a 8900 cal yr BP (El Tiro-Pass) es caracterizado por un incremento en la temperatura y humedad, así como también un cambio de la vegetación a zonas mas altas. Durante el Holoceno medio, entre 8900 a 3300 cal yr BP, tanto la temperatura como la vegetación incrementaron.

La vegetación del Bosque montano alto desarrollada en El Tiro-Pass, fue subpáramo que ocurrió en tiempos recientes, sugiriendo un clima más caliente que en la actualidad a esta elevación. Escaneo XRF de los datos refleja un período más seco desde 8900 a $6380 \mathrm{cal} \mathrm{yr}$ BP y un período mas húmedo desde 6380 a 3680 en la Laguna Rabadilla de Vaca $(3310 \mathrm{~m})$. Algas verdes Botryococcus braunii, Isoetes y Cyperaceae fueron utilizadas para reconstruir el Holoceno los phases de humedad y sequía en la Laguna Cocha Caranga. Condiciones climáticas mas secas ocurrieron desde 9700 a 6900 cal yr BP y desde 4200 a 1300 cal yr BP. Desde 6900 hasta 4200 cal yr BP y desde 1300 cal yr BP hasta la actualidad, condiciones climáticas mas húmedas caracterizaron a estas zonas.

Durante el Holoceno tardío, condiciones climáticas y vegetación actuales están presentes desde hace 3680 cal yr BP en la Laguna Rabadilla de Vaca y desde hace 3300 cal yr BP en El Tiro-Pass.

Un fuerte incremento en la intensidad del fuego durante el Holoceno medio después de 9700 cal yr BP en la Laguna Cocha Caranga y antes alrededor de 7500 cal yr BP en El Tiro-Pass, refleja el comienzo del impacto humano en los ecosistemas de la región del Parque Nacional Podocarpus. Alta ocurrencia de hierbas, documenta que fuegos anteriores influenciaron la composición florística del ecosistema bosque lluvioso de montaña y del páramo durante el Holoceno medio y tardío. La reducción de la intensidad del fuego junto con el decrecimiento de hierbas y la ausencia de polen de Zea mays despues del año $1300 \mathrm{cal}$ yr BP en la Laguna Cocha Caranga y entre 970 a 400 cal yr BP en la zona alta del Valle del Río San Francisco, 
sugiere una reducción y/o ausencia de actividades humanas posiblemente como resultado de problemas políticos. Después de la reducción y/o ausencia de la influencia humana la vegetación del bosque de montaña comenzó a recuperarse. 


\section{Acknowledgments}

Special thanks to Hermann Behling for supervise my work and being present for questions and help every time and to the co-visor Michael Kessler.

Thanks to all members of research unit for logistical support and for useful information about the study region, especially to Jürgen Homeier, Florian Werner, Fernando Rodriguez, Andres Gerique, Michael Richter, Felix Matt, Isabelle Matthias and Corinna Brunschön. Thanks to Achim Bräuning, Peter von Schnakenberg and the members of the "PREDICT" group for recollecting the pollen traps and to Henrik Stark and Markus Hofmann for accompany us during the field work. Last not least, thanks to all my helpful colleagues from the "Department of Palynology and Climate Dynamics".

The subunit D1 (Late Quaternary vegetation-, climate- and fire dynamics in the Podocarpus National Park region, southeastern Ecuadorian Andes) of the interdisciplinary research unit "Tropical Mountain Ecosystems" (FG 402) was kindly funded by the "Deutsche Forschungsgemeinschaft" (DFG).

Thanks lot to my family and friends, for supporting me during these three years.

\section{In memory of my father}

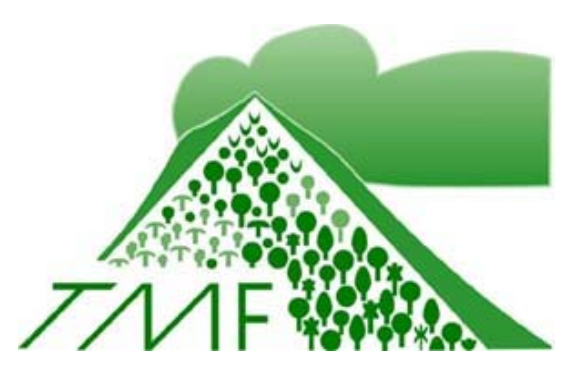

\section{Deutsche}

Forschungsgemeinschaft

\section{DFG}




\section{Introduction}

\subsection{The background}

The interdisciplinary research unit "Tropical Mountain Ecosystems" (FG 402) of the "Deutsche Forschungsgemeinschaft" (DFG) was established in 2001. The main focus based on the scientific understanding of the tropical mountain ecosystem and the potential of this ecosystem for sustainable use by humans (www.bergregenwald.de).

The subunit D1 "Past Vegetation and Fire Dynamics" of the DFG research group FG 402 started in February 2005. More than 25 scientific projects from different German universities and their Ecuadorian counter parts, including biologists, geoscientists, researchers in forestry and social anthropology were grouped into 4 project units, each with common focal points and objectives:
A: Diversity of interactive organisms in the tropical mountain rain forest
B: Matter turnover and matter fluxes
C: Sustainable agricultural and silvicultural ecosystem management in south Ecuador
D: Climate and landscape history

The results of the interdisciplinary research unit "Tropical Mountain Ecosystems" are summarised in a comprehensive study. The book "Gradients in a Tropical Mountain Ecosystem of Ecuador" (Beck et al. 2008a), published in February 2008, includes preliminary results of the studies from the subunit D1 "Past Vegetation and Fire Dynamics" (Niemann and Behling 2008d).

\subsection{Research goals}

Investigating recent vegetation/modern pollen rain relationship, the late Pleistocene and Holocene vegetation, climate and fire dynamics, as well as human impact on highly diverse mountain rain forest and paramo ecosystems in the Podocarpus National Park region, southeastern Ecuadorian Andes, three main research goals have been pointed out for this study:

Recent vegetation/modern pollen rain studies on the altitudinal gradient in comparison with sub recent pollen data, in the Podocarpus National Park region:

The forests of the Ecuadorian Andes represent one of the (plant) species richest and one of the "hottest" of the biodiversity-hotspots worldwide (Brummitt and Lughadha 2003). In order to understand past vegetation development and to test the reliability of pollen data on a strong altitudinal gradient, studies of recent vegetation/modern pollen rain relationship in comparison to sub recent pollen data are necessary for the interpretation of fossil pollen data.

In chapter 2, the comparison of recent vegetation, grouped into genera and/or families, with taxa of modern pollen rain, on an altitudinal gradient between 1800 and $3200 \mathrm{~m}$ in the ECSF research area, is used to understand the recent vegetation/modern pollen rain relationship. Supplementary to recent vegetation/modern pollen rain studies, the sub recent pollen input, definite as the mean percentages of the three uppermost samples of each core section, is represented in chapter 7.1 . 
Late Pleistocene and Holocene vegetation, climate and fire dynamics in the Podocarpus National Park region:

The tropical Andes are a relatively poor studied region; only a few palaeoenvironmental studies are available from Ecuador and neighbouring countries. Despite to investigate palaeoenvironmental changes, secondary evidences "proxies" are needed to reconstruct past vegetation, climate and fire dynamics. In this study it will be shown, that palaeoenvironmental change of the late Pleistocene and Holocene period, estimated from the Podocarpus National Park region, reflect over-regional climate development.

Chapter 3 attend the late Holocene vegetation, climate and fire dynamics of the upper Rio San Francisco valley. The chapters 4, 5 and 6 focus in general the palaeoenvironmental development of Podocarpus National Park region during late Pleistocene and Holocene period.

\section{Human impact in the Podocarpus National Park region during the past:}

The tropical Andes are under strong human impact in modern times. Ecuador suffers the highest deforestation rate in South America (FAO 2003). Industrial deforestation, pasturing and slash and burn farming catastrophically affect the highly sensitive ecosystems. For future sustainable use, the knowledge about the past is needed. It has to be considered, that human activities influenced the development of mountain forest and paramo ecosystems during the past. This study investigates the probably beginning and intensity of past human impact.

In chapter 6, the beginning of human influence, as well as the probably first settling activities in the Loja region is reconstructed. Chapter 3 and 7.2 attend the late Holocene human impact of the ecosystem in the upper Rio San Francisco valley.

\subsection{The study region}

\section{Location}

The different study sites (Figs. 1.1 and 3.2) are located in the Podocarpus National Park region, east and west of the eastern Cordillera (Cordillera Real), in the southeastern Ecuadorian Andes. The Podocarpus National Park (Fig. 1.1, small sketch), $1460 \mathrm{~km}^{3}$ in size, extends between ca. $04^{\circ} 00^{\prime}$ to $04^{\circ} 30^{\prime} \mathrm{S}$ and $79^{\circ} 10^{\prime}$ to $78^{\circ} 45^{\prime} \mathrm{W}$.

Two field campaigns have been performed, in March 2005 and in September 2006, to explore and core sediment archives and to study the modern pollen rain. In total, more than 15 cores from lakes, peat bogs and soils have been taken at different sites, 9 were processed for this study (Tab. 1.1). These cores have been choosing in fact of the location in different altitudes, reflecting the different vegetation units lower mountain forest (LMF), upper mountain forest (UMF), subparamo and paramo.

The core sites of Laguna Rabadilla de Vaca $(3310 \mathrm{~m})$ and Laguna Cocha Caranga are located on the western flank of the Cordillera Real, the core site of the El Tiro-Pass $(2810 \mathrm{~m})$ is placed directly on the eastern Andean divide and the core sites of Laguna Zurita and the ECSF research area are located on eastern flank of the Cordillera Real.

The ECSF research station ( $\left.3^{\circ} 58^{\prime} 30^{\prime \prime} \mathrm{S}, 7^{\circ} 4^{\prime} 25^{\prime \prime} \mathrm{W}, 1920 \mathrm{~m}\right)$ and the ESCF research area (between ca, 1800 to $3200 \mathrm{~m}$ ), were most activities of the interdisciplinary research unit (FG 402) placed, are located in the upper Rio San Francisco valley, north of the Podocarpus National Park, next to the main road from Loja $(2200 \mathrm{~m})$ to Zamora $(1000 \mathrm{~m})$, closed to the small village of Sabanilla. The ECSF research area extends on an about $5 \mathrm{~km}$ long mountain ridge system in north-south orientation and covers an area of about 1100 ha. 


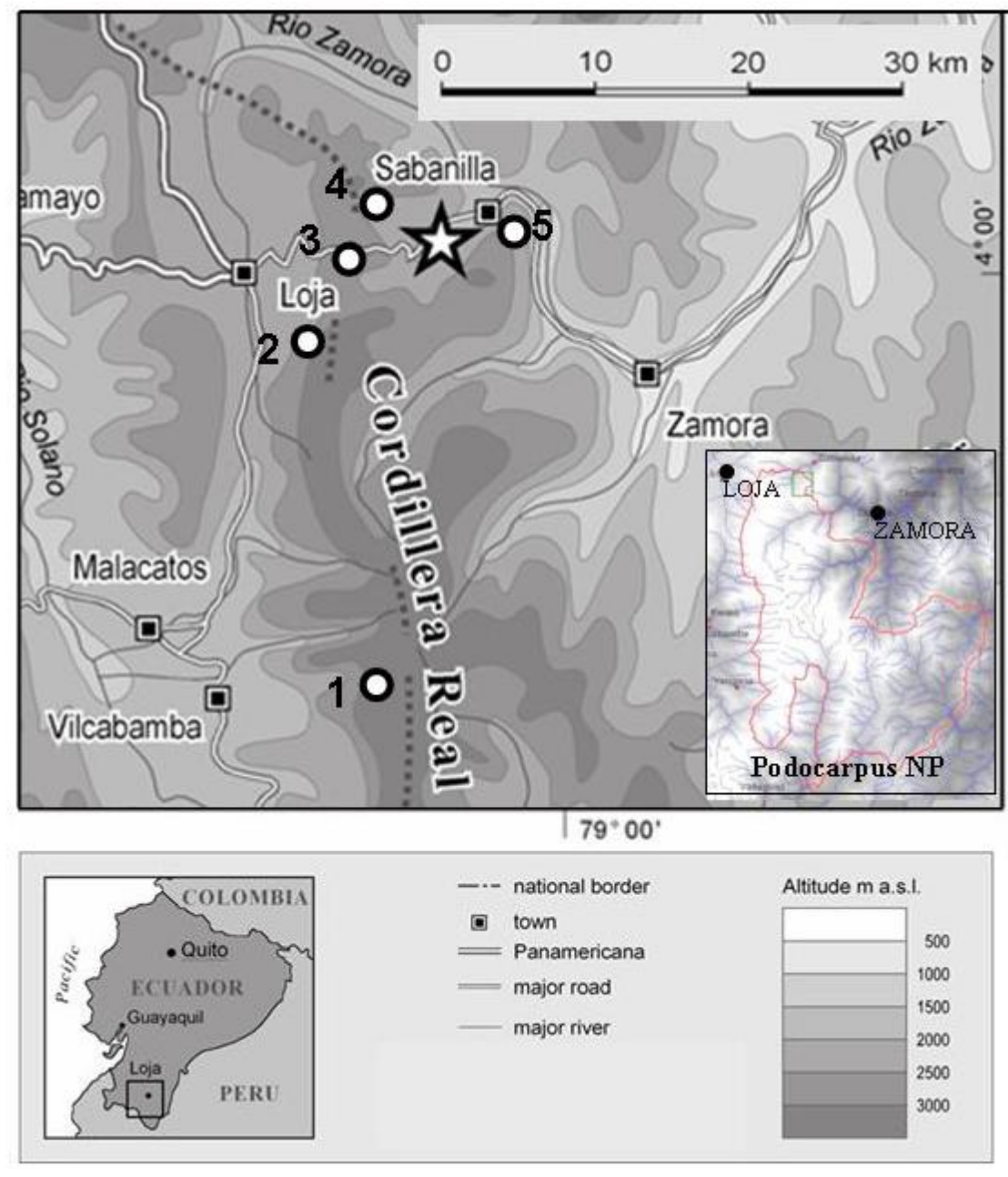

Figure1.1: The different core sites in/and around the Podocarpus National Park (small sketch) in the southeastern Ecuadorian Andes: ECSF research area (star), Laguna Rabadilla de Vaca (1), Laguna Cocha Caranga (2), El Tiro-Pass (3), Laguna Zurita (4) and Sabanilla (5). Map was modified after Richter (2003).

\section{Geomorphology}

The Andes are a mountain chain, with peaks up to an altitude of more than $6000 \mathrm{~m}$; the Ecuadorian Andes are divided into three geologic and geomorphic units, the Cordillera Occidental (Western Cordillera), the Inter-Andean Valley and the Cordillera Real (Eastern Cordillera). The southern Cordillera Real is mainly built up by the "Zamora series", consisting of Palaeozoic metamorphic rocks of widely varying metamorphic grade. Local bedrock is dominated by semipelites, quartzites and black phylites with some granitic intrusions (Litherland et al. 1994). The ECSF research area is located in the eastern part of Cordillera Real in contact to the sub Andean Zone.

The Andes of southern Ecuador and northern Peru includes the so-called Andean depression (Depression de Giron-Cuenca in Ecuador and Huancabamba in Peru) an approximately N-S oriented topographic depression. The main peaks of the mountains in this region only reach up to about $4000 \mathrm{~m}$ elevation. Active volcanoes are absent (Richter and Moreira-Munoz 2005). The main structural limits of the depression are reactivated crustal scale faults, which formed during successive Cretaceous and early Tertiary accretionary events along the Ecuadorian continental margin (Litherland et al. 1994).

During last glacial maximum (LGM), the maximum equilibrium line of the glaciers is estimated at ca. $3100 \mathrm{~m}$ for the Podocarpus National Park region, glacier ends at elevations of 


\begin{tabular}{|c|c|c|c|c|}
\hline Site name / type & $\begin{array}{l}\text { Vegetation unit } \\
\text { and elevation }\end{array}$ & Length & Coordinates (GPS) & $\begin{array}{l}\text { Age range } \\
\text { (cal yr BP) }\end{array}$ \\
\hline $\begin{array}{l}\text { El Tiro-Pass, } \\
\text { peat bog sediment core }\end{array}$ & $\begin{array}{l}\text { Subparamo } \\
(2810 \mathrm{~m})\end{array}$ & $127 \mathrm{~cm}$ & $\begin{array}{l}\text { S } 03^{\circ} 59^{\prime} 23.2^{\prime \prime} \\
\text { W } 079^{\circ} 08^{\prime} 42.7^{\prime \prime}\end{array}$ & ca. 0 - 20.000 \\
\hline $\begin{array}{l}\text { Lag. Rabadilla de Vaca, } \\
\text { lake sediment core }\end{array}$ & $\begin{array}{l}\text { Paramo } \\
\text { (3312 m) }\end{array}$ & $492 \mathrm{~cm}$ & $\begin{array}{l}\text { S } 04^{\circ} 15^{\prime} 19.7^{\prime \prime} \\
\text { W } 079^{\circ} 06^{\prime} 43.7^{\prime \prime}\end{array}$ & ca. 0 - 11.500 \\
\hline $\begin{array}{l}\text { Laguna Zurita, } \\
\text { lake sediment core }\end{array}$ & $\begin{array}{c}\text { UMF } \\
(2590 \mathrm{~m})\end{array}$ & $69 \mathrm{~cm}$ & $\begin{array}{c}\text { S } 03^{\circ} 58^{\prime} 28.8^{\prime \prime} \\
\text { W } 079^{\circ} 07^{\prime} 03.4^{\prime \prime}\end{array}$ & ca. 0 - 1380 \\
\hline $\begin{array}{l}\text { T2 I } 250 \text { (ECSF), } \\
\text { soil monolith }\end{array}$ & $\begin{array}{c}\text { LMF } \\
(1990 \mathrm{~m})\end{array}$ & $48 \mathrm{~cm}$ & $\begin{array}{c}\text { S } 03^{\circ} 58^{\prime} 51.3^{\prime \prime} \\
\text { W } 079^{\circ} 04^{\prime} 28.1^{\prime \prime}\end{array}$ & ca. 0 - 1250 \\
\hline $\begin{array}{l}\text { Refugio (ECSF), } \\
\text { soil monolith }\end{array}$ & $\begin{array}{c}\text { UMF } \\
(2520 \mathrm{~m})\end{array}$ & $44 \mathrm{~cm}$ & $\begin{array}{l}\text { S } 03^{\circ} 59^{\prime} 40.1^{\prime \prime} \\
\text { W } 079^{\circ} 03^{\prime} 59.1^{\prime \prime}\end{array}$ & ca. 0 - 1050 \\
\hline $\begin{array}{l}\text { C. de Consuelo (ECSF), } \\
\text { soil monolith }\end{array}$ & $\begin{array}{l}\text { (Sub)-paramo } \\
(3155 \mathrm{~m})\end{array}$ & $49 \mathrm{~cm}$ & $\begin{array}{l}\text { S } 04^{\circ} 00^{\prime} 08.8^{\prime \prime} \\
\text { W } 079^{\circ} 03^{\prime} 34.5^{\prime \prime}\end{array}$ & ca. 0 - 1350 \\
\hline $\begin{array}{l}\text { Lag. Cocha Caranga, } \\
\text { lake sediment core }\end{array}$ & $\begin{array}{c}\text { UMF } \\
(2710 \mathrm{~m})\end{array}$ & $65 \mathrm{~cm}$ & $\begin{array}{l}\mathrm{S} 04^{\circ} 02^{\prime} 45.1^{\prime \prime} \\
\text { W } 079^{\circ} 09^{\prime} 34.5^{\prime \prime}\end{array}$ & ca. 0 - 14.500 \\
\hline $\begin{array}{l}\text { Cocha Caranga Mire, } \\
\text { peat bog sediment core }\end{array}$ & $\begin{array}{l}\text { UMF } \\
(2710 \mathrm{~m})\end{array}$ & $69 \mathrm{~cm}$ & $\begin{array}{l}\mathrm{S} 04^{\circ} 02^{\prime} 45.1^{\prime \prime} \\
\text { W } 079^{\circ} 09^{\prime} 34.5^{\prime \prime}\end{array}$ & ca. 0 - 1550 \\
\hline $\begin{array}{l}\text { Cocha Caranga Forest, } \\
\text { soil core }\end{array}$ & $\begin{array}{c}\text { UMF } \\
(2700 \mathrm{~m})\end{array}$ & $49 \mathrm{~cm}$ & $\begin{array}{l}\mathrm{S} 04^{\circ} 02^{\prime} 45.1^{\prime \prime} \\
\text { W } 079^{\circ} 09^{\prime} 34.5^{\prime \prime}\end{array}$ & $\begin{array}{c}\text { some centuries } \\
\text { (extrapolated) }\end{array}$ \\
\hline $\begin{array}{l}\text { Sabanilla Terrace, } \\
\text { samples }\end{array}$ & $\begin{array}{l}\text { LMF } \\
(1800 \mathrm{~m})\end{array}$ & $\mathrm{ca} .85 \mathrm{~cm}$ & $\begin{array}{l}\text { S } 03^{\circ} 58^{\prime} 05,3^{\prime \prime} \\
\text { W } 079^{\circ} 03^{\prime} 11,2^{\prime \prime}\end{array}$ & $\begin{array}{c}\text { some centuries } \\
\text { (extrapolated) }\end{array}$ \\
\hline $\begin{array}{l}\text { Transect } \mathbf{A} \text {, } \\
\text { pollen rain study }\end{array}$ & $\begin{array}{l}\text { LMF, UMF, } \\
\text { (Sub)-paramo } \\
(1920-3200 \mathrm{~m})\end{array}$ & ca. $5000 \mathrm{~m}$ & $\begin{array}{c}\mathrm{S} 03^{\circ} 58^{\prime} 51.3^{\prime \prime} \\
\text { to } 04^{\circ} 00^{\prime} 08.8^{\prime \prime} \\
\text { W } 079^{\circ} 04^{\prime} 28.1^{\prime \prime} \\
\text { to } 079^{\circ} 03^{\prime} 34.5^{\prime \prime}\end{array}$ & recent \\
\hline $\begin{array}{l}\text { Transect } \mathbf{B} \text {, } \\
\text { pollen rain study }\end{array}$ & $\begin{array}{c}\text { LMF, UMF } \\
(1810-2420 \mathrm{~m})\end{array}$ & ca. $2300 \mathrm{~m}$ & $\begin{array}{c}\text { S } 03^{\circ} 58^{\prime} 51.3^{\prime \prime} \\
\text { to } 03^{\circ} 59^{\prime} 40.1^{\prime \prime} \\
\text { W } 079^{\circ} 04^{\prime} 28.1^{\prime \prime} \\
\text { to } 079^{\circ} 03^{\prime} 59.1^{\prime \prime}\end{array}$ & recent \\
\hline
\end{tabular}

Table 1.1: Site specific data of the cores, relevant for this study, is shown.

ca. 2750-2800 m (Rozsypal 2000). After Clapperton (1987) a moraine low stand is descripting at $2800 \mathrm{~m}$ for the Las Cajas National Park in western central Ecuador.

\section{Vegetation}

The description of the recent vegetation of the Podocarpus National Park region, including the ECSF research area, is based on available fieldwork data of research unit "Tropical Mountain Ecosystems". The data for this study were performed after Bussmann (2001, 2005); Lozano et al. (2003) (see chapters 3, 4, 5 and 6). Another comprehensive description of recent vegetation (see chapter 2) from ECSF research area is published in the book "Gradients in a Tropical Mountain Ecosystem of Ecuador" (Beck et al. 2008a), in the chapter "Potential Vegetation and Floristic Composition of Andean Forests in South Ecuador" (Homeier et al. 2008). A detailed vegetation map (Fig. 1.2) of the Podocarpus National Park and surrounding areas is given after Richter (2003).

The modern tree line in central and northern Ecuador is between ca. 3400 and $3600 \mathrm{~m}$. At the El Tiro-Pass, $10 \mathrm{~km}$ west of ECSF research area, the tree line is at ca. $2800 \mathrm{~m}$ (Bader 2007). The so-called Andean depression may be responsible for the low tree line ecotone in the southern Ecuadorian Andes, causing a shift of vegetation zones, as well as the tree line into lower elevations. 


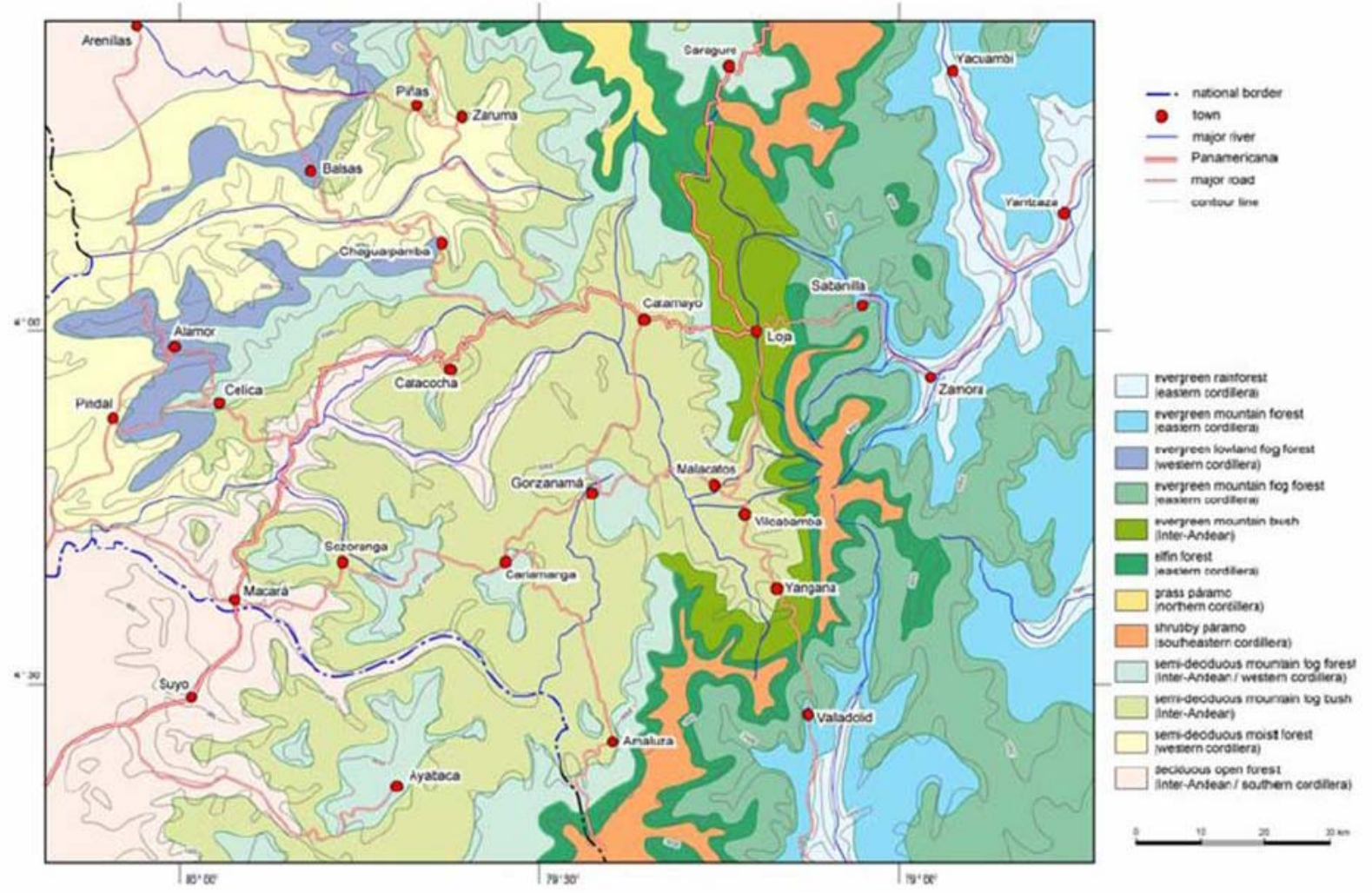

Figure 1.2: Vegetation map of the Podocarpus National Park and surrounding areas after Richter (2003).

\section{Climate}

The climate of the southeastern Ecuadorian Andes is influenced by warm moisture-laden air from the Amazon lowlands, which collides with cold mountain air masses. This produces much of the rainfall in the eastern Andean mountains. The surface wind field is locally and regionally modified by the complex topography of the Andes and the thermal land-sea contrast at the Pacific coast (Beck et al. 2008b).

The Cordillera Real forms a division that separates the moist eastern slopes of the Andes from the dry inner-Andean basins (e.g., the Loja- and Catamayo Basin). Between the eastern slopes of the Cordillera Real and the dry valley of Catamayo, which are only $70 \mathrm{~km}$ apart, annual rainfall rates drop from over $4000 \mathrm{~mm}$ to $300 \mathrm{~mm}$ (Bendix et al. 2004).

In the winter months (June-August), the trade wind system is very strong and stable, in the summer months (November-March) it is sometimes interrupted by westerly winds for a few days. The annual precipitation rate at Cajanuma (Podocarpus National Park), western slope, ridge exposed $(3400 \mathrm{~m})$ is about $5700 \mathrm{~mm}$ and the average annual temperature is about $6.9^{\circ} \mathrm{C}$ (Emck 2007).

The precipitation patterns at the ECSF research area show a strong altitudinal gradient, an increase of precipitation with the elevation, from the valley bottom $(1800 \mathrm{~m})$ to summit region $(3200 \mathrm{~m})$. Measured data of horizontal rain and cloud/fog water deposition of 4 sites from the year 1998 to 2005 along the altitudinal gradient are available: ECSF research station $(1960 \mathrm{~m})$ $2297 \mathrm{~mm}$, Plataforma $(2270 \mathrm{~m}) 2403 \mathrm{~mm}$, TS1 (2660 m) $5306 \mathrm{~mm}$, Cerro de Consuelo (3180 m) $6701 \mathrm{~mm}$ (Bendix et al. 2008).

As part of the so-called Andean depression, all summits in the southern Ecuadorian Andes are below the snowline. The recent snowline in northern Ecuador is found at ca. 4800 to 4900 m (Clapperton 1987). 


\subsection{Methods}

\section{Field work}

Lake sediments were cored, using a Livingstone piston-corer, from an inflatable rubber raft (Fig. 1.3). The up to one meter long core sections, $5 \mathrm{~cm}$ in diameter, were retained in core tubes. At Laguna Cocha Caranga the uppermost $26 \mathrm{~cm}$ of the soft lake sediment was cored with a Kajak-Corer and sampled in situ (Fig. 1.3). Peat deposits were cored, using a Russian corer, $4 \mathrm{~cm}$ in diameter (Fig. 1.3) and the soil monoliths were collected by excavation. Sections of $50 \mathrm{~cm}$ length were extruded on-site with split PVC tubes and wrapped with plastic film.

To study the modern pollen rain in the ECSF research area, 41 pollen traps $(11.5 \mathrm{~cm}$ long plastic tubes with $2.7 \mathrm{~cm}$ in diameter, Fig. 1.3) were installed in March 2005. The pollen traps were filled with ca. $5 \mathrm{ml}$ of Glycerine and covered with a synthetic net. Elevation steps of ca. $50 \mathrm{~m}$ were selected to collect the modern pollen rain along an elevation gradient between 1800 to $3200 \mathrm{~m}$. After one year the pollen traps were recollected. The pollen traps were placed along an existing trail system on a splitting mountain ridge.

To complement the reference collection, recent flush samples and samples from the herbarium of the ECSF research station, as well as the herbarium of the National University of Loja were collected.

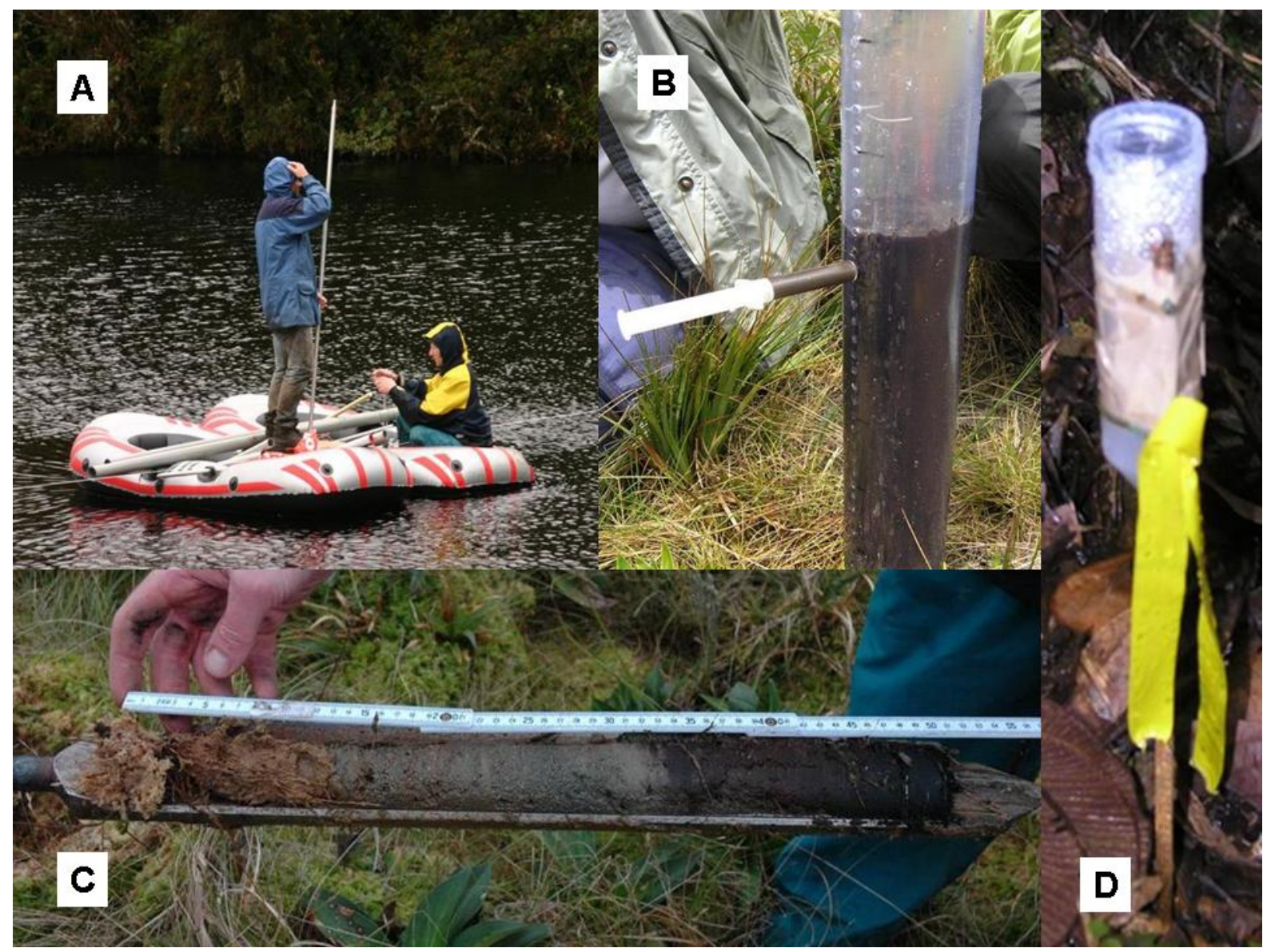

Figure 1.3: Field work methods: Lake sediments were explored with a Livingstone piston-corer (A) and/or the Kajak-Corer (B). The Russian corer (C) was used for peat bog deposits. Pollen traps (D) were installed to collect recent pollen rain. 


\section{Laboratory methods}

The lake sediment cores were spitted before processing. Sub samples $\left(0.25\right.$ or $\left.0.5 \mathrm{~cm}^{3}\right)$ were taken along the core at intervals from 1-10 cm, depending of the length of the core, as well as an interest in special core sections.

Samples, with a high content of terrigeneous material, were treated with Hydrofluoric Acid (HF); the contents of the 41 pollen traps, as well as the flush and herbarium samples were concentrated in a centrifuge. Tablets with exotic Lycopodium spores were added to each sample and dissolved with Chloric Acid ( $\mathrm{HCl})$. Lycopodium spores were used for calculation of concentration (grains or particles $/ \mathrm{cm}^{3}$ ) rates and/or influx (grains or particles $/ \mathrm{cm}^{2} / \mathrm{yr}$ ) rates. The samples were sifted and dehydrated with Acetic Acid $\left(\mathrm{CH}_{3} \mathrm{COOH}\right)$ before treatment by acetolysis. With the acetolysis, pollen and spores were coloured and samples were cleaned before preparing slides. The processing follows standard analytical methods after Faegri and Iverson (1989).

In total, 25 sub samples (soil organic matter, bulk and charcoal fragments) were taken for Accelerator Mass Spectrometer (AMS) radiocarbon dating (Tab. 1.2). The AMS radiocarbon dates were performed at the University of Erlangen/Nürnberg, Germany, providing the chronological control of the cores. Radiocarbon ages have been calibrated with CalPal (Cal Curve $50 \mathrm{ka}$ cal BP to modern) (Weninger et al. 2004), or with Calib 5.0.2 (Stuiver and Reimer 1993) using the southern hemisphere calibration curve (McCormac et al. 2004).

\begin{tabular}{|c|c|c|c|c|c|}
\hline Core name & Lab. code & Dated material & $\begin{array}{l}\text { Core } \\
\text { depth }\end{array}$ & 14C yr BP & cal yr BP \\
\hline El Tiro-Pass & Erl-8371 & Leaf & $31 \mathrm{~cm}$ & $1828 \pm 55$ & $1767 \pm 63$ \\
\hline El Tiro-Pass & Erl-8899 & Bulk Sample & $48 \mathrm{~cm}$ & $2972 \pm 43$ & $3155 \pm 70$ \\
\hline El Tiro-Pass & Erl-8898 & Bulk Sample & $77 \mathrm{~cm}$ & $7850 \pm 71$ & $8713 \pm 131$ \\
\hline El Tiro-Pass & Erl-9454 & Bulk Sample & $97 \mathrm{~cm}$ & $11.187 \pm 104$ & $13.082 \pm 139$ \\
\hline El Tiro-Pass & Erl-8372 & Bulk Sample & $126 \mathrm{~cm}$ & $16.517 \pm 128$ & $19.836 \pm 306$ \\
\hline Lag.Rabadilla de Vaca & Erl-8896 & Bulk Sample & $96 \mathrm{~cm}$ & $1887 \pm 38$ & $1823 \pm 51$ \\
\hline Lag.Rabadilla de Vaca & Erl-8895 & Bulk Sample & $278 \mathrm{~cm}$ & $4603 \pm 45$ & $5311 \pm 124$ \\
\hline Lag.Rabadilla de Vaca & Erl-11032 & Bulk Sample & $360 \mathrm{~cm}$ & $6822 \pm 88$ & $7686 \pm 79$ \\
\hline Lag.Rabadilla de Vaca & Erl-8375 & Bulk Sample & $450 \mathrm{~cm}$ & $9262 \pm 81$ & $10.438 \pm 114$ \\
\hline Laguna Zurita & Erl-8376 & Bulk Sample & $33 \mathrm{~cm}$ & $395 \pm 43$ & $425 \pm 72$ \\
\hline Laguna Zurita & Erl-11031 & Bulk Sample & $51 \mathrm{~cm}$ & $1015 \pm 46$ & $912 \pm 58$ \\
\hline T2/250 (ECSF) & Erl-8901 & Soil org.matter & $21 \mathrm{~cm}$ & $-708 \pm 42$ & \\
\hline T2/250 (ECSF) & Erl-9448 & Charcoal & $33 \mathrm{~cm}$ & $915 \pm 38$ & $845 \pm 52$ \\
\hline T2/250 (ECSF) & Erl-8902 & Soil org.matter & $46 \mathrm{~cm}$ & $-533 \pm 48$ & \\
\hline Refugio (ECSF) & Erl-8900 & Soil org.matter & $17 \mathrm{~cm}$ & $-602 \pm 34$ & \\
\hline Refugio (ECSF) & Erl-8377 & Charcoal & $34,5 \mathrm{~cm}$ & $854 \pm 45$ & $798 \pm 68$ \\
\hline C.de Consuelo (ECSF) & Erl-8803 & Charcoal & $18 \mathrm{~cm}$ & $1016 \pm 53$ & $915 \pm 66$ \\
\hline C.de Consuelo (ECSF) & Erl-8904 & Bulk Sample & $36 \mathrm{~cm}$ & $1236 \pm 47$ & $1172 \pm 69$ \\
\hline Lag. Cocha Caranga & Erl-11035 & Bulk sample & $23 \mathrm{~cm}$ & $1208 \pm 48$ & $1149 \pm 70$ \\
\hline Lag. Cocha Caranga & Erl-11395 & Bulk sample & $55 \mathrm{~cm}$ & $7413 \pm 52$ & $8256 \pm 58$ \\
\hline Lag. Cocha Caranga & Erl-11036 & Bulk sample & $61 \mathrm{~cm}$ & $10636 \pm 38$ & $12569 \pm 140$ \\
\hline Cocha Caranga Mire & Erl-11393 & Bulk sample & $43 \mathrm{~cm}$ & $259 \pm 44$ & $301 \pm 114$ \\
\hline Cocha Caranga Mire & Erl-11394 & Bulk sample & $67 \mathrm{~cm}$ & $1636 \pm 46$ & $1523 \pm 71$ \\
\hline Cocha Caranga Forest & Erl-11392 & Soil org. matter & $26 \mathrm{~cm}$ & $-160 \pm 35$ & \\
\hline Cocha Caranga Forest & in order & Charcoal & $30 \mathrm{~cm}$ & & \\
\hline
\end{tabular}

Table 1.2: The laboratory code, dated material with the corresponding core depth, AMS-Radiocarbon dates and calibrated ages of the cores, relevant for this study. 
For the sediment cores of Laguna Rabadilla de Vaca and Laguna Zurita, non-destructively magnetic susceptibility $(\kappa)$ scanning was performed on split cores with a Bartington MS2F point sensor at $1 \mathrm{~cm}$ resolution. Non-destructively, an Avaatech XRF-scanner provided semiquantitative analysis of Al, Si, S, K, Ca, Ti, Mn and Fe (Richter et al. 2006; Tjallingii et al. 2007) was performed in $1 \mathrm{~cm}$ intervals.

\section{Identification of pollen and spores}

About 300 pollen grains were counted for each sample. A representative sample, from the sediment core of Laguna Rabadilla de Vaca (380 cm core depth), was counted to 500 pollen grains (Fig. 1.4), reflecting that most taxa were identified until 300 pollen grains.

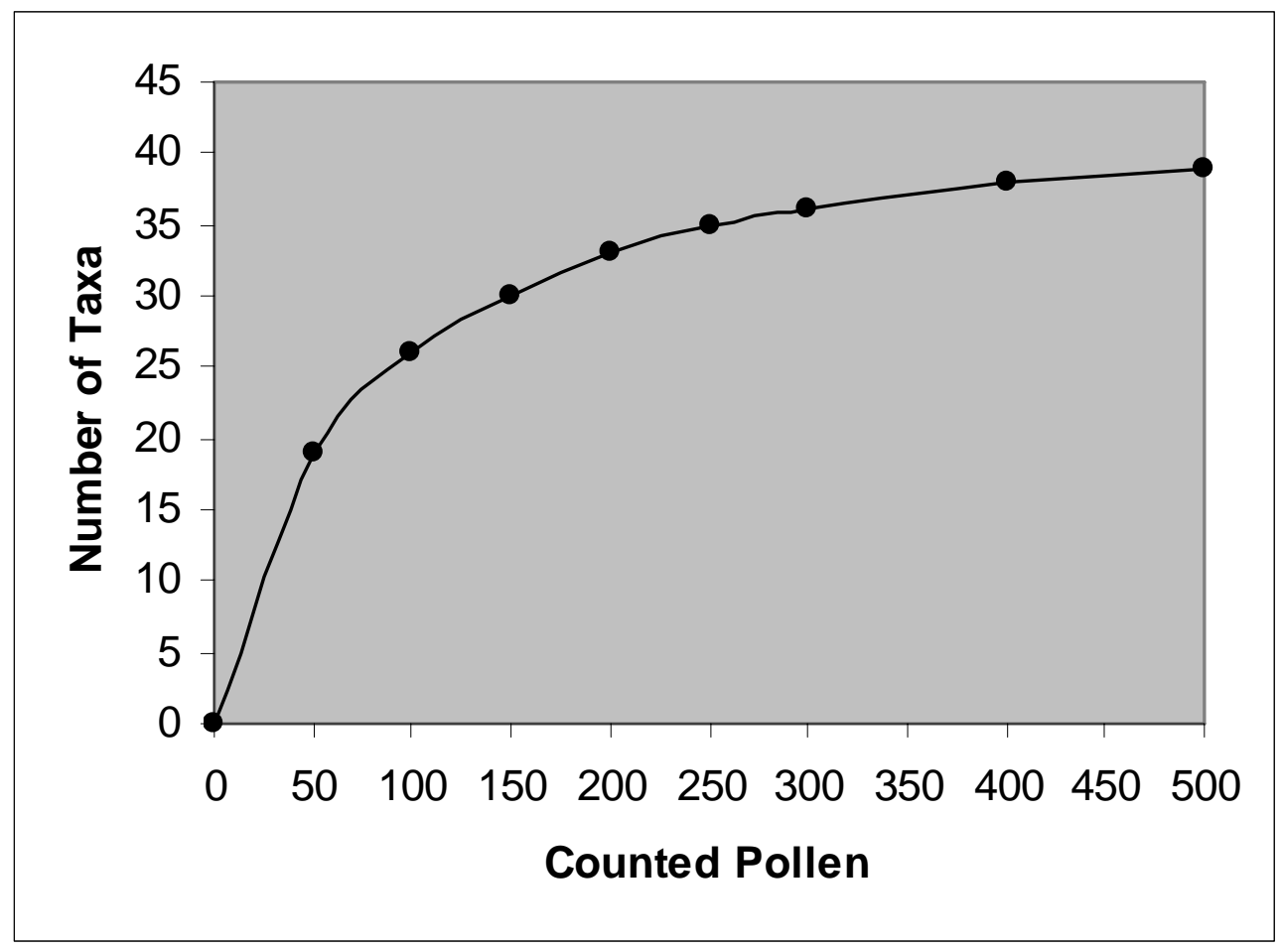

Figure 1.4: The relationship between counted pollen grains and the number of identified taxa.

It has to be considered that pollen samples often contain a high number of terrigeneous and organic material, as well as charcoal fragments. The preservation of pollen and spores strongly varies; slides from recent samples, as well as from lake and peat bog deposits mostly offer a high quality. Slides from soil deposits often have been a low quality (Fig. 1.5). There is no doubt about that the preservation of pollen and spores influences their identification. However, about $90 \%$ of pollen and spore taxa have been identified each sample.

The identification of pollen and spores relied on the reference collection from the Department of Palynology and Climate Dynamics, with about 3000 neotropical species and on the reference collection with about 300 species, collected during the fieldwork and in the herbarium of the ECSF research station and the herbarium of the National University of Loja, as well as on literature (Behling 1993; Hooghiemstra 1984). The number of identified pollen and spore taxa and the number of sub samples (counted slides) of each core is given in Table 1.3 . 


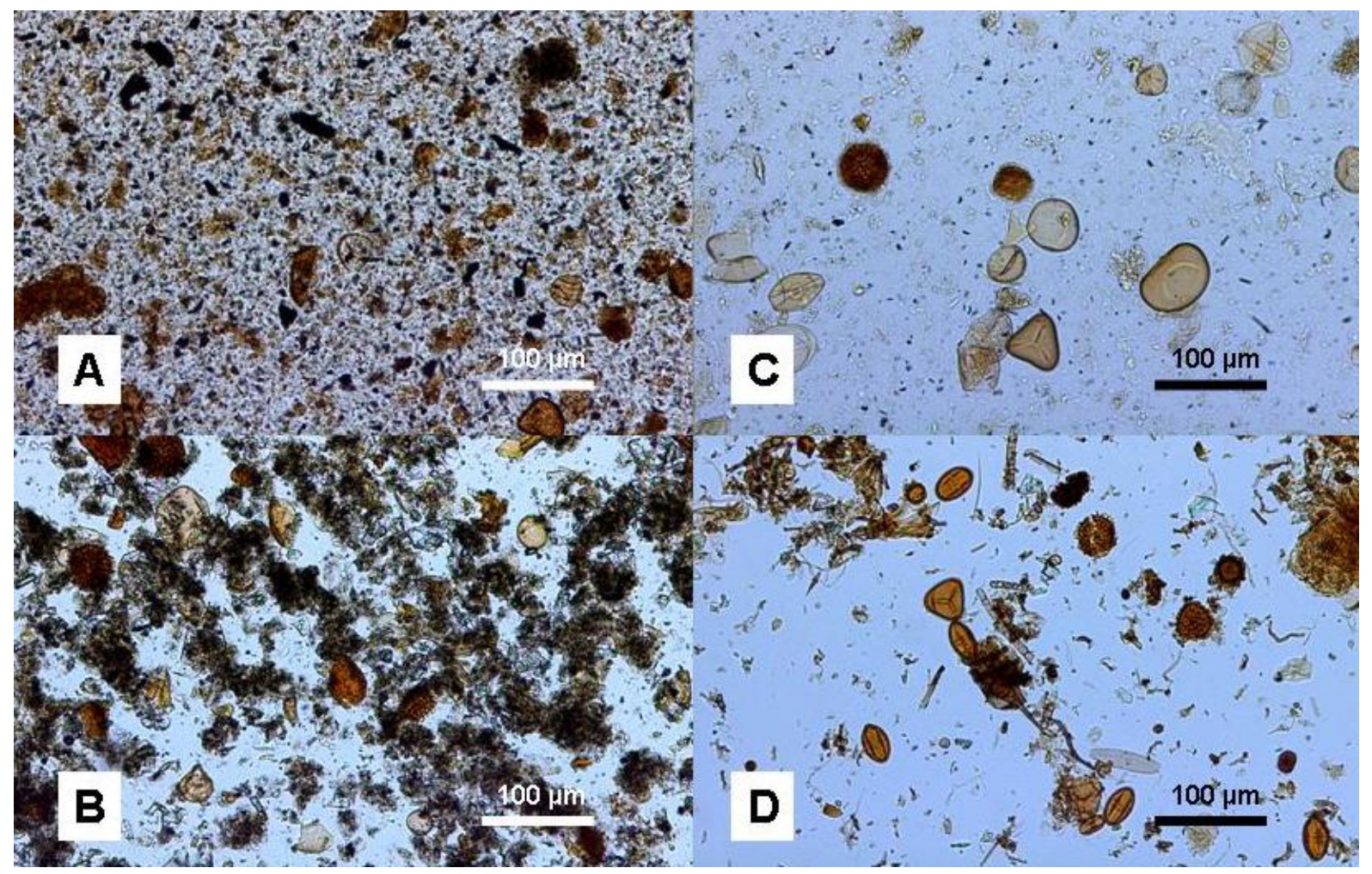

Figure 1.5: Photographs of different pollen slides from Laguna Cocha Caranga (A), Cerro de Consuelo (B), El Tiro-Pass and Transect A (D). Slides A and B show a high number of terrigeneous and organic material, as well as charcoal fragments. The preservation of pollen and spores is on a low quality level. Slides $\mathrm{C}$ and $\mathrm{D}$ shows a low number of terrigeneous and organic material, the preservation of pollen and spores is from high quality.

\begin{tabular}{lcc}
\hline Record name & $\begin{array}{c}\text { Number of } \\
\text { identified Taxa }\end{array}$ & $\begin{array}{c}\text { Sub samples } \\
\text { (Counted slides) }\end{array}$ \\
\hline T2 / 250 (ECSF) & 91 & 25 \\
Laguna Zurita & 101 & 24 \\
Refugio (ECSF) & 72 & 23 \\
Laguna Cocha Caranga & 109 & 34 \\
Cocha Caranga Mire & 86 & 18 \\
Cocha Caranga Forest & 54 & 13 \\
El Tiro-Pass & 90 & 64 \\
Cerro de Consuelo (ECSF) & 87 & 25 \\
Laguna Rabadilla de Vaca & 108 & 52 \\
Transect A & 129 & 27 \\
Transect B & 128 & 14 \\
\hline
\end{tabular}

Table 1.3: The number of identified pollen and spore taxa, as well as the number of sub samples of the different cores, relevant for this study are shown.

\section{Calculation and presentation of the data}

The pollen sum includes trees-, shrub- and herb pollen and excludes fern spores and aquatic pollen taxa. Pollen of Cyperaceae were excluded in the pollen sum of the Laguna Zurita and the Laguna Cocha Caranga pollen records, due to the high number of these taxa. 
The ecological grouping of the identified pollen taxa follows available data of the research group FG 402 and literature (Bussmann 2001, 2005; Homeier and Werner 2005; Homeier and Werner 2008; Lozano et al. 2003). Due to the different description of vegetation units, in this study the terms lower mountain forest (LMF), upper mountain forest (UMF), subparamo and paramo, are used.

Pollen and spore data are presented as percentages of the pollen sum, as well as concentration (grains $/ \mathrm{cm}^{3}$ ) rates and/or influx (grains $/ \mathrm{cm}^{2} / \mathrm{yr}$ ) rates, in the pollen diagrams. Carbonized particles $(10-150 \mu \mathrm{m})$ and Botryococcus were counted on pollen slides and presented as concentration (particles or individuals $/ \mathrm{cm}^{3}$ ) rates and/or influx (particles or individuals $/ \mathrm{cm}^{2} / \mathrm{yr}$ ) rates. The software TILIA and TILIAGRAPH were used to plot the pollen and spore data (Grimm 1987). Cluster analysis (CONISS) of terrestrial pollen (and spore) taxa produces a dendrogram which help to identify the pollen zones.

XRF- and magnetic susceptibility scanning data (cnts) were plotted on a correlation matrix (Spearman Rank Order Correlation). A significant correlation among elements is given on a high correlation coefficient; only $\mathrm{Si}, \mathrm{Ti}, \mathrm{Fe}$ and magnetic susceptibility were used for palaeoenvironmental reconstruction.

\section{Methodically limits}

About 1206 species in 422 genera and 130 families of native spermatophytes have been recorded from the ECSF research area (Homeier and Werner 2008). However, the identification of the pollen of all these species is limited. Due to the high number of species each genera or family (e.g. Melastomataceae and Weinmannia), as well as the similarity of the pollen grains and their varying preservation (Fig. 1.5), it was not possible to subdivide most taxa into species.

\subsection{Perspectives}

This comprehensive research study "Late Quaternary vegetation, climate and fire dynamics in the Podocarpus National Park region, southeastern Ecuadorian Andes" performs a high number of research questions. Hence, this study well reflects recent vegetation/modern pollen rain relationship on an altitudinal transects between 1800 and $3200 \mathrm{~m}$ elevation. Due to the limited elevation of the Cerro de Consuelo Mountain, the Paramo vegetation unit is under represented. A transect study, covering higher elevation could be useful. The Holocene period is well documented in three records, for a high resolution palaeoenvironmental study of the transition from late Pleistocene to Holocene period, including the Younger Dryas event, further records are needed. Least not last, the successful pilot study of a probably prehistoric terrace offers the possibility to compare available archaeological field data in relationship to palynological studies.

The new formed research unit (FOR 816) "Biodiversity and sustainable Management of a megadiverse Mountain Ecosystem in southern Ecuador" including the subunit "Reconstruction and modelling of late Quaternary and modern landscape dynamics" started in February 2007. Further records will be analysed and modelled under using data from this study. 


\title{
2. Recent vegetation/modern pollen rain relationship studies on an altitudinal transect of mountain forest and paramo vegetation in the southeastern Ecuadorian Andes
}

\section{Review of Palaeobotany and Palynology (in review)}

\author{
Holger Niemann, Hermann Behling
}

Department of Palynology and Climate Dynamics, Albrecht-von-Haller-Institute for Plant Sciences, University of Göttingen, Untere Karspüle 2, 37073 Göttingen, Germany

\begin{abstract}
To study the recent vegetation/modern pollen rain relationship in total 41 pollen traps have been installed for one year on two altitudinal transects between 1800 and $3200 \mathrm{~m}$ elevation in the mountain forest and (sub)-paramo vegetation of the Estacion Cientifica San Francisco (ECSF) research area, located between Loja and Zamora in the southeastern Ecuadorian Andes.

Results show that the altitudinal vegetation gradient of lower mountain forest (LMF), upper mountain forest (UMF) and (sub)-paramo of the ECSF research area in general is well reflected in the modern pollen rain data. Cluster analyses on the pollen rain data by CONISS, clearly reflects the zonation of the different vegetation zones. A relatively high number of pollen taxa correspond to the altitudinal distribution of genera and families of the modern vegetation. Characteristic pollen and spore taxa for the LMF are Alchornea, Hyeronima and Heliocarpus, for the UMF are Purdiaea, Clusia, Myrsine, Myrtaceae, Podocarpaceae, Rubiaceae, the Symplocos peruviana type, Cyathea spp. and Elaphoglossum and for the (sub)-paramo are Clethra, Cyperaceae, Ericaceae, the Baccharis type, Valeriana and Jamesonia.

The modern tree line in the research area is at ca. $2790 \mathrm{~m}$, which is pointed out by an increase of (sub)-paramo taxa and a decrease of mountain forest taxa in the pollen rain data.
\end{abstract}

Keywords: Ecuador, mountain forest, paramo, modern pollen rain, vegetation zones, tree line 


\subsection{Introduction}

Studies on recent vegetation and their pollen rain, e.g. collected in pollen traps over on year, provide important background information in the interpretation of late Quaternary pollen records. This palaeoecological information is needed to understand the natural composition and dynamics of modern ecosystems for proper management and conservation.

The Ecuadorian Andes harbour the most species rich ecosystems on earth (Barthlott et al. 2005). Despite its high biodiversity huge areas have been strongly affected during the last decades in particular. Natural vegetation regeneration and sustainable management is urgently needed as well as conservation of less degraded areas.

So far only a few vegetation/pollen rain studies are available from the northern Andes (Fig. 2.1): From the Sumapaz area, eastern slope of the Central Cordillera of Colombia between 1120 and $4250 \mathrm{~m}$ (Melief 1985), from the High Plain of Bogota (Colombia) between 2600 and $3800 \mathrm{~m}$ (Hooghiemstra and Cleef 1984), from Mera site between 300 and $3400 \mathrm{~m}$ in Ecuadorian Amazonia (Bush et al. 1990), from Laguna Baja between 2800 and $3800 \mathrm{~m}$ in northern Peru (Hansen and Rodbell 1995), from Junin area between 900 and $4600 \mathrm{~m}$ in central Peru (Hansen et al. 1984) and from Madre de Dios River between 340 and $3530 \mathrm{~m}$ in southeastern Peru (Weng et al. 2004). Studies from southeastern Ecuador, which is located in the so called Andean depression, are not available.

In order to study the highly diverse mountain ecosystems in southeastern Ecuador, extended research has been carried out in the framework of the "Deutsche Forschungsgemeinschaft" (DFG) research group "Tropical Mountain Ecosystems" focusing on Podocarups National Park (Beck et al. 2008 a). Currently (2007-2010) more than 25 different research group are working in this area. The palaeoecological work, under analysing more than 10 different lakepeat- and soil cores in the Podocarpus National Park region started in 2005. For the interpretation of already available and future records, studies on recent vegetation/modern pollen rain relationship are needed (Niemann and Behling 2008c; Niemann et al. 2007).

In this study we want to address following main questions: (1) How is the recent vegetation reflected in the modern pollen rain spectra? (2) Can the different vegetation units lower and upper mountain forest and (sub)-paramo separated by pollen data? (3) Are there any key taxa for the different vegetation units? (4) How is the tree line reflected in the modern pollen rain data?

The results will provide important information for the interpretation of fossil pollen records, past vegetation development and shifts of vegetation units, which will be used for future modelling of past vegetation dynamics of the Podocarpus National Park region.

\subsection{Site description}

\section{Location}

The Andes of southern Ecuador and northern Peru are part of the so-called Andean depression (Depression de Giron-Cuenca in Ecuador and Huancabamba in Peru). The main peaks of the mountains in this region reach up to about $4000 \mathrm{~m}$. Active volcanoes are absent (Richter and Moreira-Munoz 2005). The southern Cordillera Real is mainly built up by the geologic unit of the "Zamora series", consisting of Palaeozoic metamorphic rocks of widely varying metamorphic grade. Local bedrock is dominated by semipelites, quartzites and black phylites with some granitic intrusions (Litherland et al. 1994).

The study area (Fig. 2.1) is located on the western slope of the Cordillera Real between the city of Loja $(2200 \mathrm{~m})$ in the inter-Andean valley and the city of Zamora $(1000 \mathrm{~m})$ at the Amazonian flank of the eastern Ecuadorian Andes. The ECSF research station $(1920 \mathrm{~m})$ is located in the Rio San Francisco valley north of the Podocarpus National Park, about $15 \mathrm{~km}$ 
east from Loja, next to the small village of Sabanilla. The ECSF research area $\left(3^{\circ} 58^{\prime} 30^{\prime \prime} \mathrm{S}\right.$ and $79^{\circ} 4^{\prime} 25^{\prime \prime} \mathrm{W}$, between 1800 and $3200 \mathrm{~m}$ ), is located on an about $5 \mathrm{~km}$ long mountain ridge system in north-south orientation and covers an area of about 1100 ha (Fig. 2.2). The research area is intensively studied by the research group "Tropical Mountain Ecosystems" (www.bergregenwald.de).

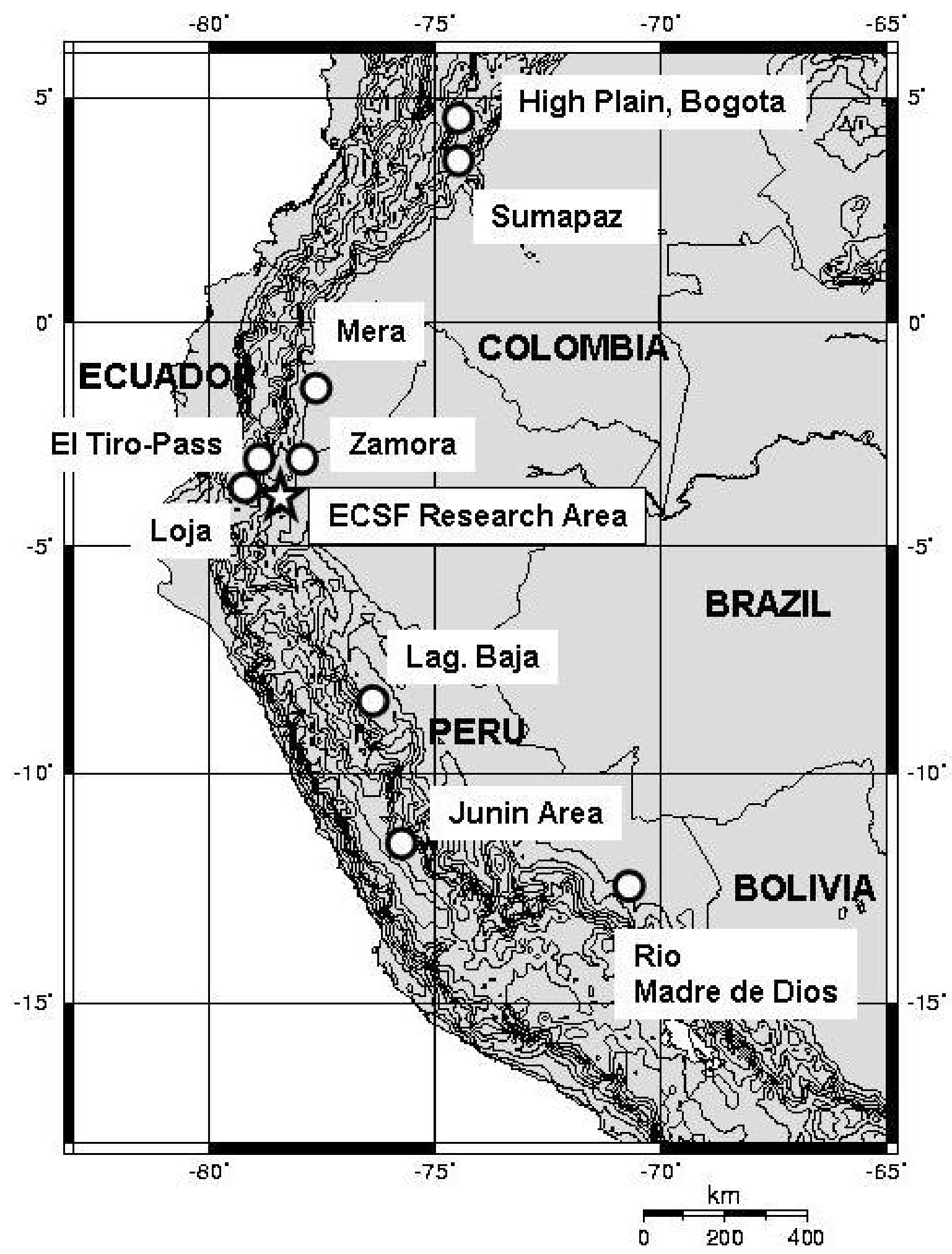

Figure 2.1: Map of northwestern tropical South America, showing the ECSF research area (star) and other locations discussed in the text (spots). The map was created under using OMC (www.aquarius.geomar.de). 


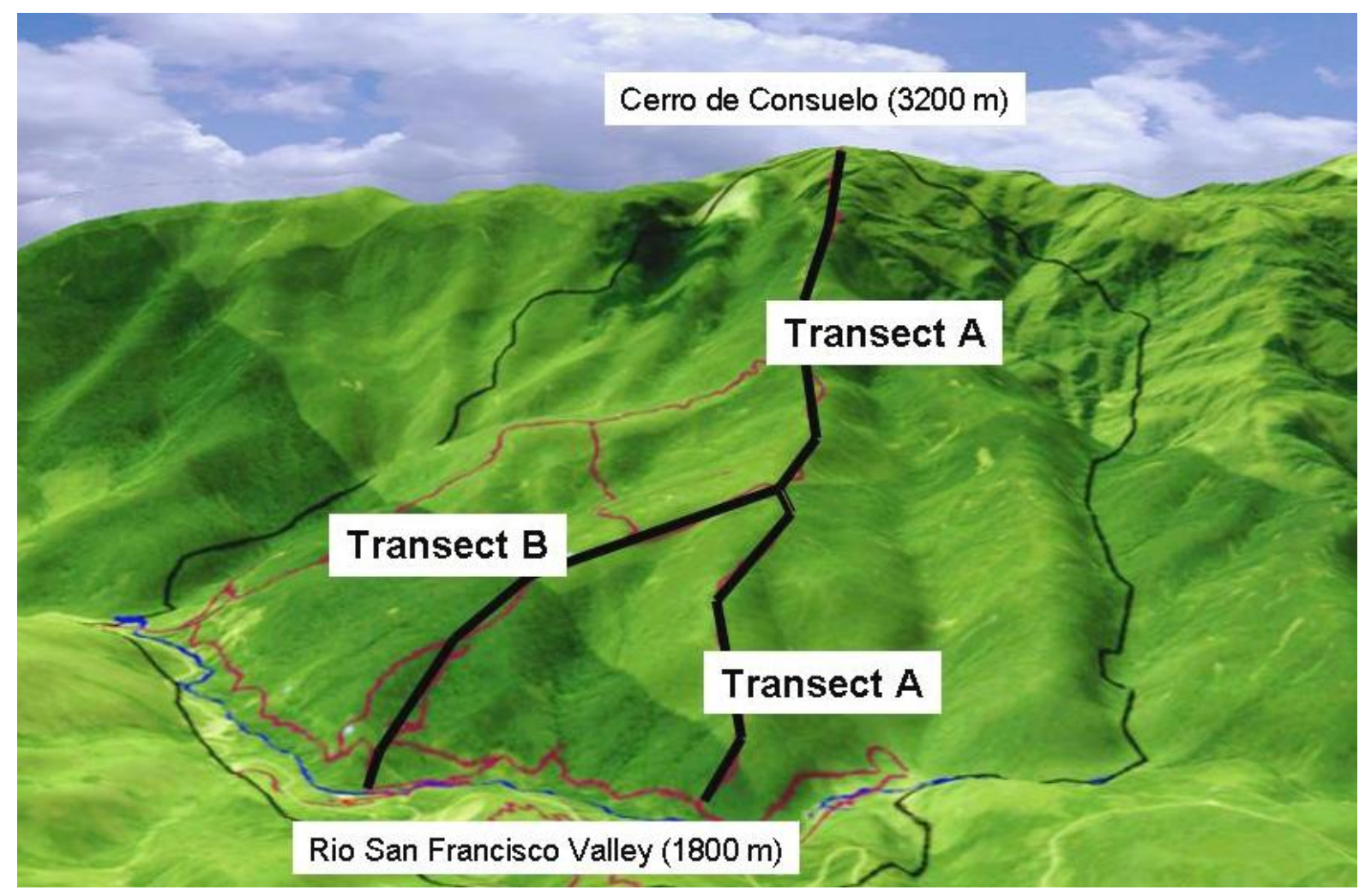

Figure 2.2: 3-D picture showing the ECSF research area with to location of transects A and B of modern pollen rain, specified after Rollenbeck et al. (2005).

\section{Climate}

The climate of Ecuador is dominated by the tropical trade wind regime which is well established in the mid- and higher troposphere, with strong easterlies all over the year. The surface wind field is locally and regionally modified by the complex topography of the Andes and the thermal land-sea contrast at the Pacific coast. The south-eastern part of the country encompassing the ECSF research area is also mainly influenced by easterlies, but westerlies occasionally occur especially in austral summer. The main rainy season lasts from April to August even if rainfall is high all through the year (Beck et al. $2008 \mathrm{~b}$ ). As part of the socalled Andean depression, all summits in the southern Ecuadorian Andes are below the snowline.

The Cordillera Real forms a division that separates the moist eastern slopes of the Andes from the dry inner-Andean basins (e.g., the Loja- and Catamayo Basin). Between the eastern slopes of the Cordillera Real and the dry valley of Catamayo, which are only $70 \mathrm{~km}$ apart, annual rainfall rates drop from over $4000 \mathrm{~mm}$ to $300 \mathrm{~mm}$ (Bendix et al. 2004).

The precipitation patterns at the ECSF research area show a strong altitudinal gradient, an increase of precipitation with the elevation, from the valley bottom $(1800 \mathrm{~m})$ to summit region $(3200 \mathrm{~m})$. Measured data of horizontal rain and cloud/fog water deposition of 4 sites from the year 1998 to 2005 along the altitudinal gradient are available: ECSF research station $(1960 \mathrm{~m})$ $2297 \mathrm{~mm}$, Plataforma (2270 m) $2403 \mathrm{~mm}$, TS1 (2660 m) $5306 \mathrm{~mm}$, Cerro de Consuelo (3180 m) $6701 \mathrm{~mm}$ (Bendix et al. 2008). 


\section{Recent vegetation}

The description of the recent vegetation of the Podocarpus National park region follows the results of the fieldwork of research group "Tropical Mountain Ecosystems" (Homeier et al. 2008).

The lower mountain forest (LMF) occurs between ca. 1300 and $2100 \mathrm{~m}$ with an extremely diverse, two-storied tree stratum and a canopy height up to $30 \mathrm{~m}$. Undisturbed communities of this type can be found particularly on steep slopes with 30 to $50^{\circ}$ inclination, as well as up to ca. $2300 \mathrm{~m}$ at the bottom of wind-protected river valleys. Characteristic species are Alzatea verticillata (Alzateaceae), Chamaedorea pinnatifrons, Dictyocaryum lamarckianum and Wettinia maynensis (Arecaceae), Piptocoma discolor and Mikania spp. (Asteraceae), Tabebuia chrysantha (Bignoniaceae), Vismia tomentosa (Clusiaceae), Cyathea caracasana (Cyatheaceae), Inga acreana and other Inga spp. (Fabaceae), Nectandra lineatifolia, N. membranacea and Ocotea aciphylla (Lauraceae), Miconia imitans, M. punctata (Melastomataceae), Cedrela montana (Meliaceae), Ficus spp., Morus insignis and Sorocea trophoides (Moraceae), Piper spp. (Piperaceae), Heliocarpus americanus (Tiliaceae).

The upper mountain forest (UMF) occurs between ca. 2100 and $2700 \mathrm{~m}$, replaced by a low, monotypic formation, with only one tree stratum. The canopy heights attain up to $25 \mathrm{~m}$. Characteristic trees are Ilex rimbachii (Aquifoliaceae), Hedyosmum spp. (Chloranthaceae), Clethra revoluta (Clethraceae), Clusia ducu and Tovomita weddeliana (Clusiaceae), Weinmannia pinnata and Weinmannia spp. (Cunoniaceae), Cyathea bipinnatifida (Cyatheaceae), Purdiaea nutans (Clethraceae), Bejaria aestuans (Ericaceae), Alchornea grandiflora (Euphorbiaceae), Macrocarpaea revoluta (Gentianaceae), Eschweilera sessilis (Lecythidaceae), Licaria subsessilis, Ocotea benthamiana and Persea ferruginea (Lauraceae), Graffenrieda emarginata, G. harlingii and Tibouchina lepidota (Melastomataceae), Myrica pubescens (Myricaceae), Myrsine coriacea (Myrsinaceae), Calyptranthes pulchella and Myrcia spp. (Mytraceae), Podocarpus oleifolius and Prumnopitys montana (Podocarpaceae), Dioicodendron dioicum and Palicourea spp. (Rubiaceae), Matayba inelegans (Sapindaceae), Drimys granadensis (Winteraceae).

Between ca. 2700 to $3100 \mathrm{~m}$ (up to the timberline), the subparamo (elfin-forest) occurs. This forest type forms the timberline with a canopy height rarely up to 6-8 m. Characteristic species are Ilex spp. (Aquifolicaeae), Puya eryngioides (Bromeliaceae), Hedyosmum cumbalense and $H$. scabrum (Chloranthaceae), Clethra ovalifolia (Clethraceae), Clusia elliptica (Clusiaceae), Weinmannia cochensis, W. loxensis and W. rollottii (Cunoniaceae), Gaultheria reticulata (Ericaceae), Escallonia myrtilloides (Grossulariaceae), Orthrosanthus chimborazensis (Iridaceae), Persea ferruginea and Ocotea infravoveolata (Lauraceae), Gaiadendron punctatum (Loranthaceae), Graffenrieda harlingii (Melastomataceae), Myrteola phylicoides (Myrtaceae), Hesperomeles ferruginea (Rosaceae), Styrax foveolaria (Styracaceae), Symplocos sulcinervia (Symplocaceae), Gordonia fruticosa (Theaceae), as well as impenetrable bamboo of Chusquea falcata and C. scandens (Poaceae).

The paramo occurs in the crest region of the Cordillera Real above timberline at ca. 3100 to $3700 \mathrm{~m}$. This vegetation attains heights of up to $2 \mathrm{~m}$. Characteristic species are Gynoxis spp. (Asteraceae), Puya eryngioides and Puya nitida (Bromeliaceae), Hypericum decandrum (Clusiaceae), Rhynchospora vulcani (Cyperaceae), Bejaria resinosa, Disterigma pentandrum, Gaultheria erecta, G. reticulata and Vaccinium floribundum (Ericaceae), Escallonia myrtilloides (Grossulariaceae), Brachyotum andreanum (Melastomataceae), Neurolepis asymmetrica, N. elata, N. laegaardii and the bamboo species Chusquea neurophylla (Poaceae), Monnina arbuscula (Polygalaceae), Valeriana microphylla and V. plantaginea (Valerianaceae).

The floristic composition of most important trees with a $\mathrm{dbh}>5 \mathrm{~cm}$ (number of percentages of total tree species) from the ECSF research area is given after Homeier (2008): 
San Francisco Valley and major ravines below ca. 2200 m (LMF): Melastomataceae 12.7\%, Rubiaceae 12.3\%, Lauraceae 10.9\%, Piperaceae 8.6\% and Mimosaceae 7.5\%. Ridges and upper slopes from ca. 1900 to 2100 m (LMF): Melastomataceae 25.7\%, Lauraceae 18.6\%, Euphorbiaceae 11.8\%, Chloranthaceae $6.1 \%$ and Myrsinaceae 5.7\%. Ridges and Upper Slopes at ca. 2100 to $2250 \mathrm{~m}$ (UMF): Melastomataceae 17.6\%, Clusiaceae 10.8\%, Rubiaceae, Euphorbiaceae $10.2 \%$ and Myrtaceae 9.6\%. Ridges at ca. 2250 to $2700 \mathrm{~m}$ (UMF): Melastomataceae 26.1\%, Clethraceae (Purdiaea) 12.7\%, Clusiaceae 10.1\%, Ericaceae 6.7\% and Cunoniaceae $5.9 \%$.

The modern tree line in central Ecuador is at ca. $3400 \mathrm{~m}$ (La Libertad), at ca. $3500 \mathrm{~m}$ (Atillo) and in northern Ecuador at ca. $3600 \mathrm{~m}$ (Guandera). At the El Tiro-Pass, $10 \mathrm{~km}$ west of (ECSF) research area, the tree line is at ca. $2800 \mathrm{~m}$ (Bader 2007).

\subsection{Material and methods}

\section{Recent vegetation}

The software TILIA and TILIAGRAPH were used to plot the number selected species, added to genera or families (Grimm 1987). Genera or families of recent vegetation are selected, according to the identified pollen taxa. The ecological grouping of selected taxa (Fig. 2.3) into lower and upper mountain forest and (sub)-paramo is given after Homeier et al. (2008). This method allows a comparison between recent vegetation and modern pollen rain data on an altitudinal gradient. The number of species (not the number of individuals) on an altitudinal scale (100 $\mathrm{m}$ intervals of elevation) is given in Table 2.1, following available field work data after Lozano et al. (2003), Homeier and Werner (2005) and Lehnert et al. (2006).

\section{Modern pollen rain spectra}

In the ECSF research area, 41 pollen traps $(11.5 \mathrm{~cm}$ long plastic tubes with $2.7 \mathrm{~cm}$ in diameter) were installed in March 2005. The pollen traps were filled with ca. $5 \mathrm{ml}$ Glycerin and covered with a synthetic net. Elevation steps of ca. $50 \mathrm{~m}$ are selected to collect the modern pollen rain along an elevation gradient between 1800 to $3200 \mathrm{~m}$. After one year the pollen traps were recollected. The location of the pollen traps was along an existing trail system on a splitting mountain ridge. Transect A starts ca. $70 \mathrm{~m}$ above the valley of Rio San Francisco $(1920 \mathrm{~m})$ and hits the summit at $3200 \mathrm{~m}$. Transect B starts at the valley bottom of Rio San Francisco (1810 m) and connects Transect A at $2420 \mathrm{~m}$ (Fig. 2.2 and Tab. 2.2).

The contents of the 41 pollen traps were concentrated in a centrifuge and treated by acetolysis. Before treatment, exotic Lycopodium spores were added to each sample for calculation of pollen influx (pollen/ $\mathrm{cm}^{2} / \mathrm{yr}$ ) rates. About 300 pollen grains were counted for each sample. The pollen sum includes trees, shrubs, and herbs and excludes fern spores. Pollen identification relied on the reference collection from the second author with about 3000 neotropical species and literature (Behling 1993; Hooghiemstra 1984) and on a reference collection with about 300 species, collected during the fieldwork and from the herbarium of the ECSF research station.

The ecological grouping of the identified pollen taxa into LMF, UMF and (sub)-paramo follows available data in the literature (Homeier and Werner 2005; Lozano et al. 2003). Pollen and spore data are presented in pollen diagrams as percentages of the pollen sum. The software TILIA and TILIAGRAPH were used to plot the pollen and spore data (Grimm 1987). Cluster analysis (CONISS) of pollen taxa is used to prepare a dendrogram to identify the pollen zones (2.4 to 2.7$)$. 


\begin{tabular}{|c|c|c|c|c|c|c|c|c|c|c|c|c|c|c|c|}
\hline $\begin{array}{l}\text { Elevation }(\mathrm{m} \times 10) \\
\text { Taxa }\end{array}$ & 320 & 310 & 300 & 290 & 280 & 270 & 260 & 250 & 240 & 230 & 220 & 210 & 200 & 190 & 180 \\
\hline Saurauia ACTI * & & & & & & & & & & & & 1 & 3 & 3 & 3 \\
\hline Bomarea ALST & 3 & 2 & 2 & 2 & 2 & 2 & 2 & 2 & 2 & 2 & 1 & 1 & 1 & 1 & 1 \\
\hline Ilex AQUI & & 1 & 1 & 1 & 2 & 4 & 4 & 5 & 4 & 4 & 3 & 3 & 2 & 1 & 1 \\
\hline ASTERACEAE & 16 & 15 & 15 & 15 & 12 & 12 & 12 & 12 & 12 & 12 & 6 & 6 & 6 & 6 & 6 \\
\hline Baccaris AST & 1 & 2 & 2 & 2 & 3 & 3 & 3 & 3 & 3 & 3 & 2 & 2 & & & \\
\hline Senecio AST & 1 & 1 & 1 & 1 & 1 & 1 & 1 & 1 & 1 & 1 & 1 & 1 & & & \\
\hline Alnus BETU & & & & & 1 & 1 & 1 & 1 & 1 & 1 & 1 & 1 & 1 & 1 & 1 \\
\hline Centropogon CAMP & 2 & 2 & 2 & 2 & 1 & 1 & 1 & 1 & 1 & 1 & 1 & 1 & & & \\
\hline Cecropia CECR * & & & & & & & 1 & 1 & 1 & 1 & 1 & 1 & 2 & 2 & 2 \\
\hline Clethra CLETH & 3 & 3 & 3 & 3 & 3 & 3 & 3 & 3 & 3 & 3 & 1 & 1 & 1 & 1 & 1 \\
\hline Purdiaea CLETH * & & & & & 1 & 1 & 1 & 1 & 1 & 1 & 1 & 1 & 1 & & \\
\hline Hedyosmum CHLO & 1 & 1 & 1 & 1 & 2 & 2 & 2 & 2 & 2 & 2 & 1 & 1 & & & \\
\hline Clusia CLUS & 1 & 1 & 1 & 1 & 4 & 5 & 5 & 5 & 5 & 5 & 3 & 3 & 1 & 1 & 1 \\
\hline Weinmannia CUN & 4 & 4 & 4 & 4 & 4 & 4 & 4 & 4 & 4 & 4 & 2 & 2 & & & \\
\hline CYPERACEAE & 3 & 3 & 3 & 3 & 4 & 4 & 4 & 4 & 4 & 4 & & & & & \\
\hline ERICACEAE & 14 & 13 & 13 & 13 & 12 & 12 & 12 & 12 & 12 & 12 & 9 & 9 & & & \\
\hline Acalypha EUPH * & & & & & & & & & & & & 2 & 1 & 1 & 1 \\
\hline Alchornea EUPH * & & & & & & & & & 1 & 1 & 1 & 3 & 3 & 3 & 1 \\
\hline Croton EUPH * & & & & & & & & & & & & & & 1 & \\
\hline Hyeronina EUPH * & & & & & & & & & & & 1 & 3 & 4 & 4 & 3 \\
\hline Eschweilleria LECY * & & & & & 1 & 1 & 1 & 1 & 1 & 1 & 1 & 1 & & & \\
\hline MELASTOMATACEAE & 18 & 14 & 14 & 14 & 15 & 13 & 13 & 13 & 13 & 13 & 7 & 7 & 2 & 2 & 2 \\
\hline MORAC. / URTICAC.* & & & & & & & & & & 1 & 2 & 4 & 8 & 12 & 9 \\
\hline Myrica MYRIC * & & & & & & & 1 & 1 & 1 & 1 & 1 & 1 & 1 & 1 & 1 \\
\hline Myrsine MYRS & 1 & 2 & 2 & 2 & 2 & 3 & 3 & 3 & 3 & 3 & 2 & 2 & 2 & 2 & 2 \\
\hline MYRTACEAE * & & & & & & 1 & 2 & 3 & 5 & 6 & 7 & 5 & 6 & 3 & 4 \\
\hline PODOCARPACEAE & & 1 & 1 & 1 & 1 & 2 & 2 & 2 & 2 & 2 & 2 & 2 & 2 & 2 & 2 \\
\hline Piper PIP * & & & & & & & & & & 2 & 5 & 7 & 17 & 22 & 16 \\
\hline POACEAE & 7 & 8 & 8 & 8 & 7 & 5 & 5 & 5 & 5 & 5 & 2 & 2 & 2 & 2 & 2 \\
\hline RUBIACEAE & 2 & 1 & 1 & 1 & 5 & 7 & 7 & 7 & 7 & 7 & 4 & 4 & 4 & 4 & 4 \\
\hline Styrax STYR & & & & & & & & 2 & 1 & 1 & 1 & 1 & & & \\
\hline Symplocos SYM & 2 & 2 & 2 & 2 & 2 & 2 & 2 & 2 & 2 & 2 & 1 & 1 & & & \\
\hline Heliocarpus TIL * & & & & & & & & & & & & & 1 & 1 & 1 \\
\hline Celtis ULM * & & & & & & & & & & & & & & & 1 \\
\hline Valeriana VAL & 2 & 2 & 2 & 2 & 1 & 1 & 1 & 1 & 1 & 1 & & & & & \\
\hline Blechnum BLECH & 3 & 2 & 2 & 2 & 2 & 2 & 2 & 2 & 2 & 2 & 1 & 1 & 1 & 1 & 1 \\
\hline Cyathea CYA ** & & 1 & 2 & 1 & 4 & 5 & 8 & 11 & 9 & 5 & 4 & 3 & 3 & 4 & 4 \\
\hline Cyathea conjugata CYA ** & & & & & & & & 1 & 1 & 1 & 1 & 1 & 1 & 1 & 1 \\
\hline Cyathea peladensis CYA ** & & & & & & & & 1 & 1 & 1 & & & & & \\
\hline Polystichum DRY ** & & & & & & & 1 & 2 & & & & & & 1 & 2 \\
\hline Sticherus GLEI ** & & & & & 1 & 2 & 5 & 4 & 3 & 3 & 1 & 1 & 1 & 1 & 1 \\
\hline Elaphoglossum LOM & 2 & 1 & 1 & 1 & 3 & 4 & 4 & 4 & 4 & 4 & 4 & 4 & 3 & 3 & 3 \\
\hline Lycopodiella LYC & & 2 & 2 & 2 & 1 & 1 & 1 & 1 & 1 & 1 & & & & & \\
\hline Jamesonia PTER ** & & & & 1 & & & & & & & & & & & \\
\hline
\end{tabular}

Table 2.1: Number of species (rounded) on an altitudinal scale of $100 \mathrm{~m}$ intervals of elevation, after Lozano et al. (2003); Homeier and Werner (2005) * and Lehnert et al. (2006) **.

\section{Site name Altitude ( $m$ ) Length ( $m)$ Number of Number of Vegetation zone ident. Taxa pollen traps}

\begin{tabular}{llllll}
\hline Transect A & $1920-3200$ & ca. 5000 & 129 & 27 & LMF, UMF, (Sub) -Paramo \\
Transect B & $1810-2420$ & ca. 2300 & 128 & 14 & LMF, UMF \\
\hline
\end{tabular}

Table 2.2: Site specific data of modern pollen rain transect A and B in southeastern Ecuador. 


\subsection{Results}

\section{Recent vegetation (Fig. 2.3)}

The LMF vegetation zone (ca. 1800-2100 m) is characterised by a high number of Piper (722 species), Moraceae/Urticaceae (4-12 species), Hyeronima (3-4 species), Alchornea and Saurauia (both 1-3 species), Cecropia and Acalypha (both 1-2 species). UMF genera and families, such as Myrtaceae (3-5 species), Rubiaceae (4 species), Myrsine and Podocarpaceae (both 2 species) show lowest number of species in this zone, as well as (sub)-paramo families such Melastomataceae (2-7 species), Ericaceae (0-9 species) and Asteraceae (6 species). Fern genera, such as Elaphoglossum (3-4 species) and Cyathea (2-4 species) show a relatively low number of species in this zone.

The UMF vegetation zone (ca. 2100-2700 m) shows a very low number of Piper (2-5 species), Moraceae/Urticaceae (1-2 species), Alchornea and Cecropia (1 species). UMF genera and families, such as Myrtaceae (1-7 species), Rubiaceae (4-7 species), Clusia and Ilex (both 3-5 species), Weinmannia (2-4 species), Myrsine (2-3 species), Podocarpaceae (2 species), Hedyosmum, Symplocos and Styrax (all 1-2 species) show highest number of species in this zone. (Sub)-paramo genera and families, such as Melastomataceae (7-13 species), Ericaceae (9-12 species), Asteraceae (6-12 species), Poaceae (2-5 species), Cyperaceae (0-4 species), Baccharis (2-3 species) and Clethra (1-3 species) show a high number of species. Fern genera, such as Cyathea (4-11 species), Sticherus (1-5 species), Elaphoglossum (4 species), Blechnum (1-2 species) and Polystichum (0-2 species) show highest number of species in this zone.

The (sub)-paramo vegetation zone (ca. 2700-3200 m) is marked by the missing of LMF genera and families. UMF genera and families, such as Rubiaceae (0-4 species), Clusia (1-4 species), Weinmannia (3-4 species) and Myrsine (1-2 species) show a low number of species in this zone. (Sub)-paramo genera and families, such as Melastomataceae (14-18 species), Ericaceae (12-14 species), Asteraceae (12-16 species), Poaceae (6-8 species), Cyperaceae (3-4 species), Clethra (3 species), Baccharis (1-3 species), Valeriana and Centropogon (both 1-2 species) show highest number of species in this zone. Fern genera, such as Cyathea (1-4 species), Blechnum (2-3 species), Elaphoglossum (1-3 species), and Lycopodiella (1-2 species) show a relatively low number of species in this zone.

\section{Transect A of modern pollen rain (Figs. 2.4 and 2.5)}

Zone A-1 (ca. 1920-2185 m) is marked by the highest representation of pollen taxa originated from the lower LMF. Hyeronima (5-15\%), Heliocarpus (25\% in one sample), Alchornea (2$12 \%)$, Moraceae/Urticaceae (2-6\%) are well represented. Pollen taxa originated from the UMF show a relatively stable representation. Hedyosmum (6-12\%), Weinmannia (3-12\%), Eschweilera (2-12\%), Purdiaea and Myrsine (both 2-5\%) are common. Pollen taxa originated from (sub) -paramo show relativelv high representation in this zone. Melastomataceae (748\%), Poaceae (3-7\%), the Baccharis type (1-6\%) and Asteraceae subf. Asterioideae (1-4\%) are represented. Fern spores $(20-60 \%)$, especially trilete spores are frequent. Pollen influx (7000-23,000 pollen/ $\left.\mathrm{cm}^{2} / \mathrm{yr}\right)$ is highest in this zone.

Zone A-2 (ca. 2185-2790 m) shows a relatively stable representation of pollen taxa originated from the lower LMF. Moraceae/Urticaceae (3-12\%), Acalypha (2-10\%), Celtis (1-9\%), Cecropia (1-7\%) Trema (1-5\%) and Alchornea (0-5\%) are common. Hyeronima and Heliocarpus become rare or absent. Pollen taxa originated from the UMF show highest representation in this zone. Weinmannia (3-30\%), the Symplocos peruviana type (2-15\% and $40 \%$ in one sample), Purdiaea (1-20\%), Hedyosmum (2-12\%), Myrtaceae (1-12\%), Myrsine (1-8\%), Alnus (1-7\%) and Clusia (1-5\%) are well represented. Pollen taxa originated from 


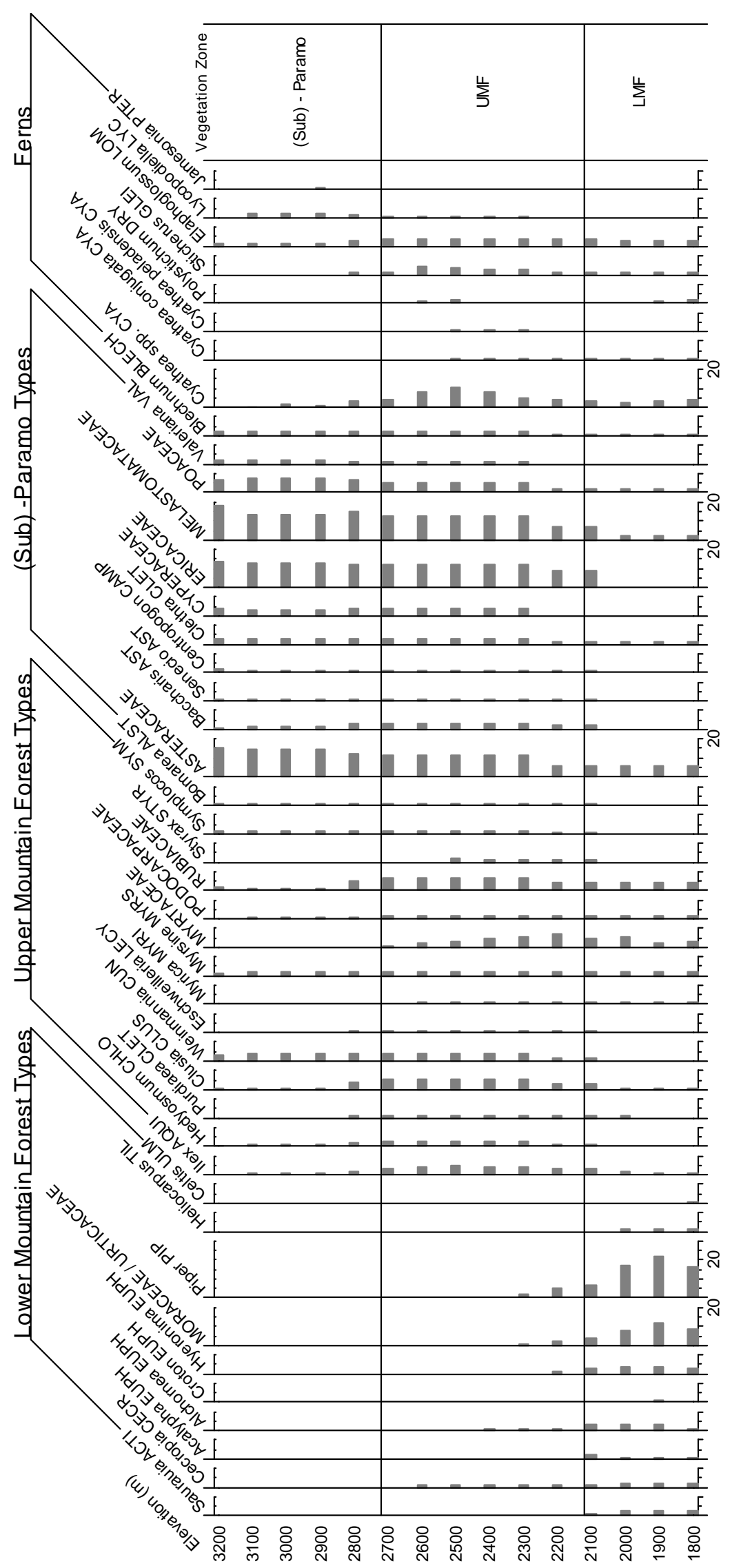

Figure 2.3: Diagram showing the number of selected species (not individuals), added to genera or families on an altitudinal gradient. The taxa is grouped into lower mountain forest (LMF), upper mountain forest (UMF) and (sub)-paramo, based on field work data from Homeier and Werner (2005); Lehnert et al. (2006) and Lozano et al. (2003). 


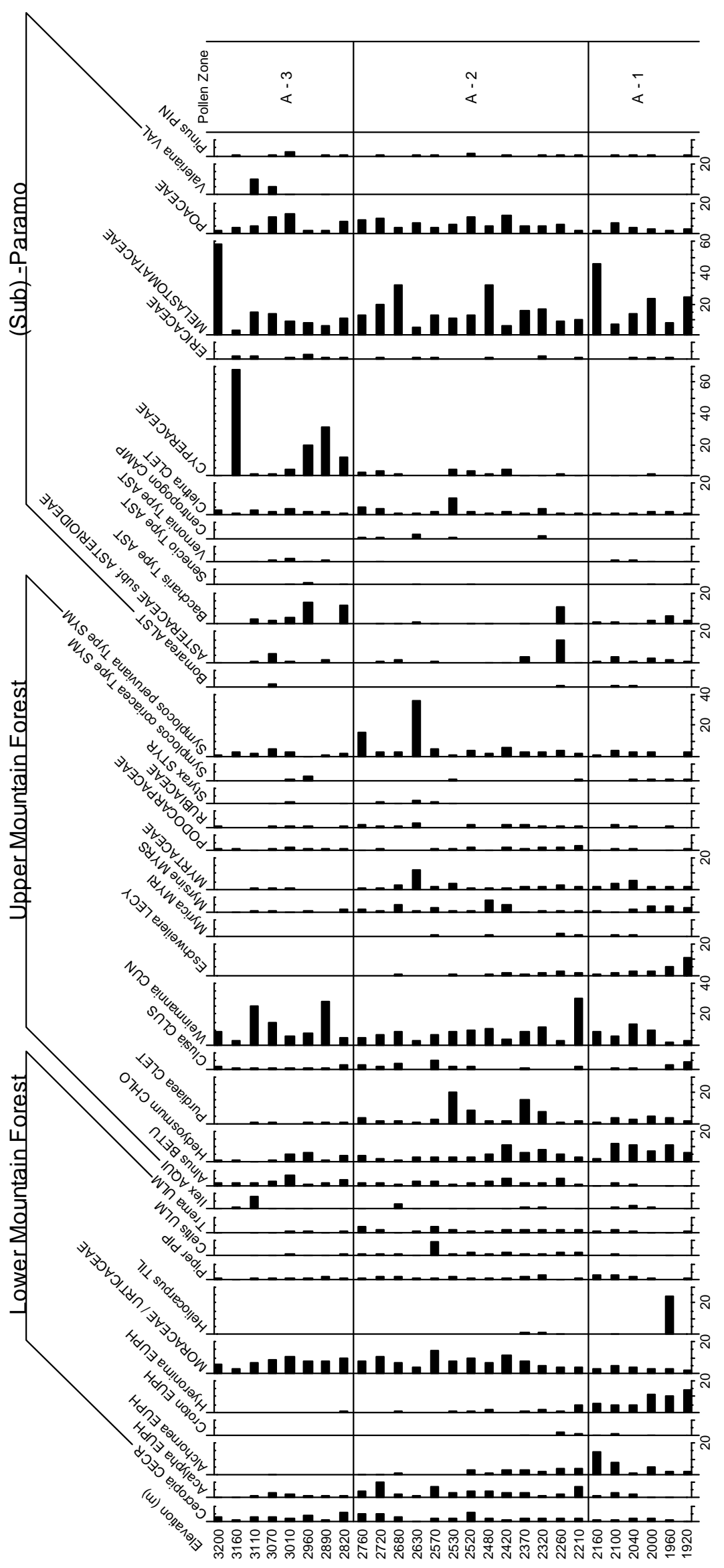

Figure 2.4: Pollen percentage diagram of modern pollen rain spectra (Transect A, 1900-3200 m) from ECSF research area in southeastern Ecuador showing selected pollen taxa grouped into lower mountain forest (LMF), upper mountain forest (UMF) and (sub)-paramo. 


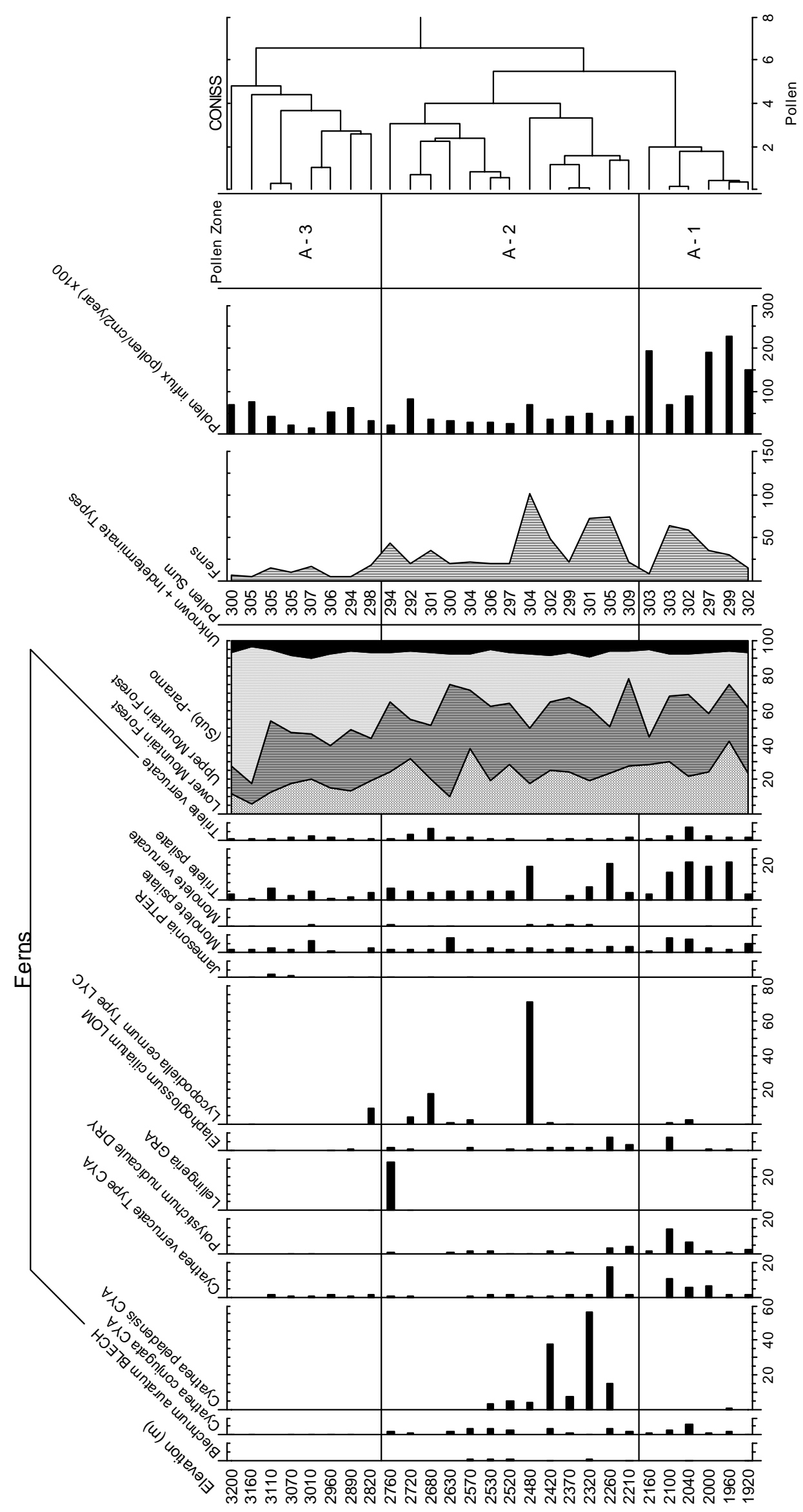

Figure 2.5: Pollen percentage diagram of modern pollen rain spectra (Transect A, 1900-3200 m) from ECSF research area in southeastern Ecuador showing selected spore taxa, sums of ecological groups, the pollen sum, the pollen influx and the CONISS dendrogram. 


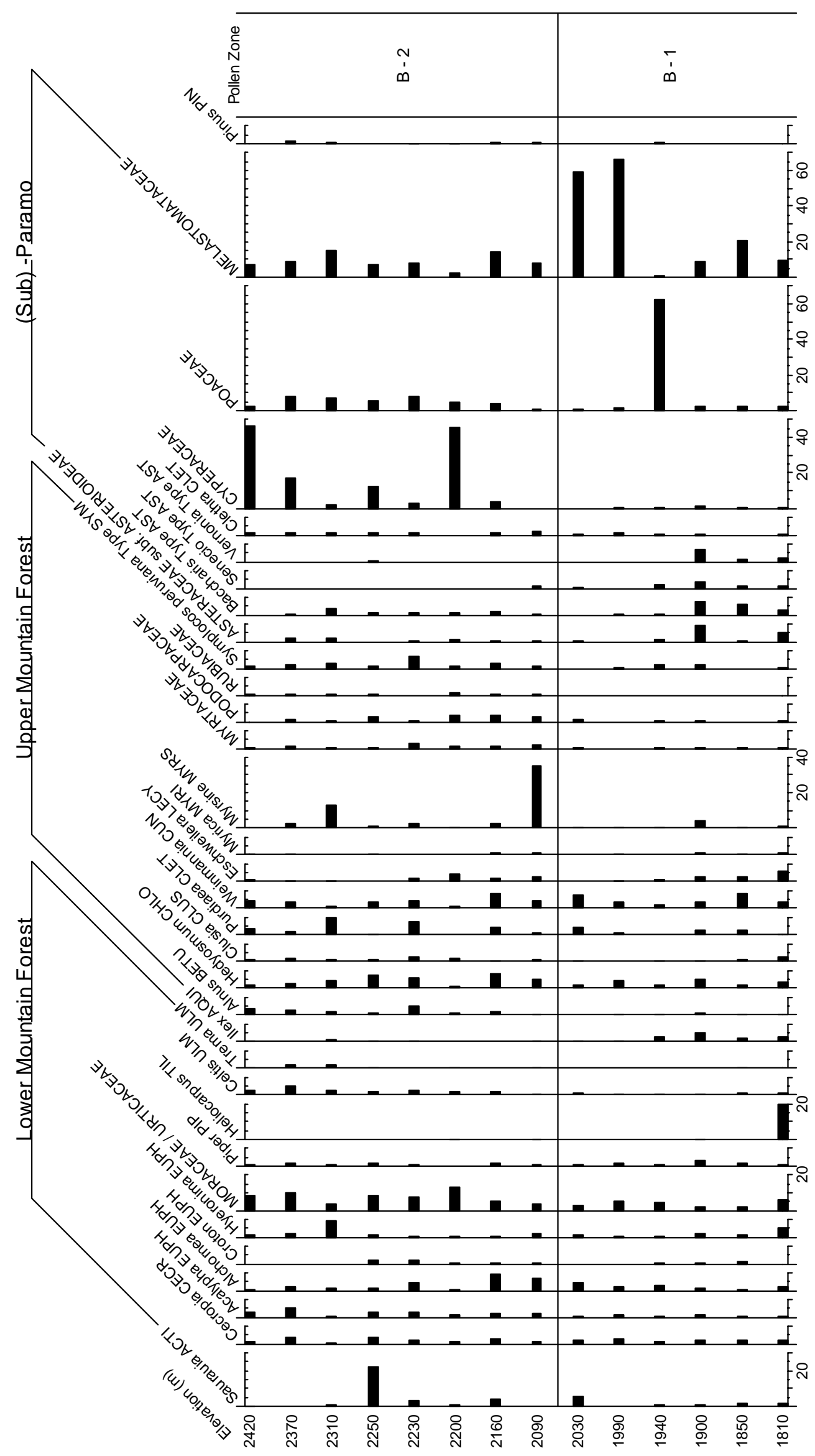

Figure 2.6: Pollen percentage diagram of modern pollen rain spectra (Transect B, 1810-2420 m) from ECSF research area in southeastern Ecuador showing selected pollen taxa grouped into lower mountain forest (LMF), upper mountain forest (UMF) and (sub)-paramo. 


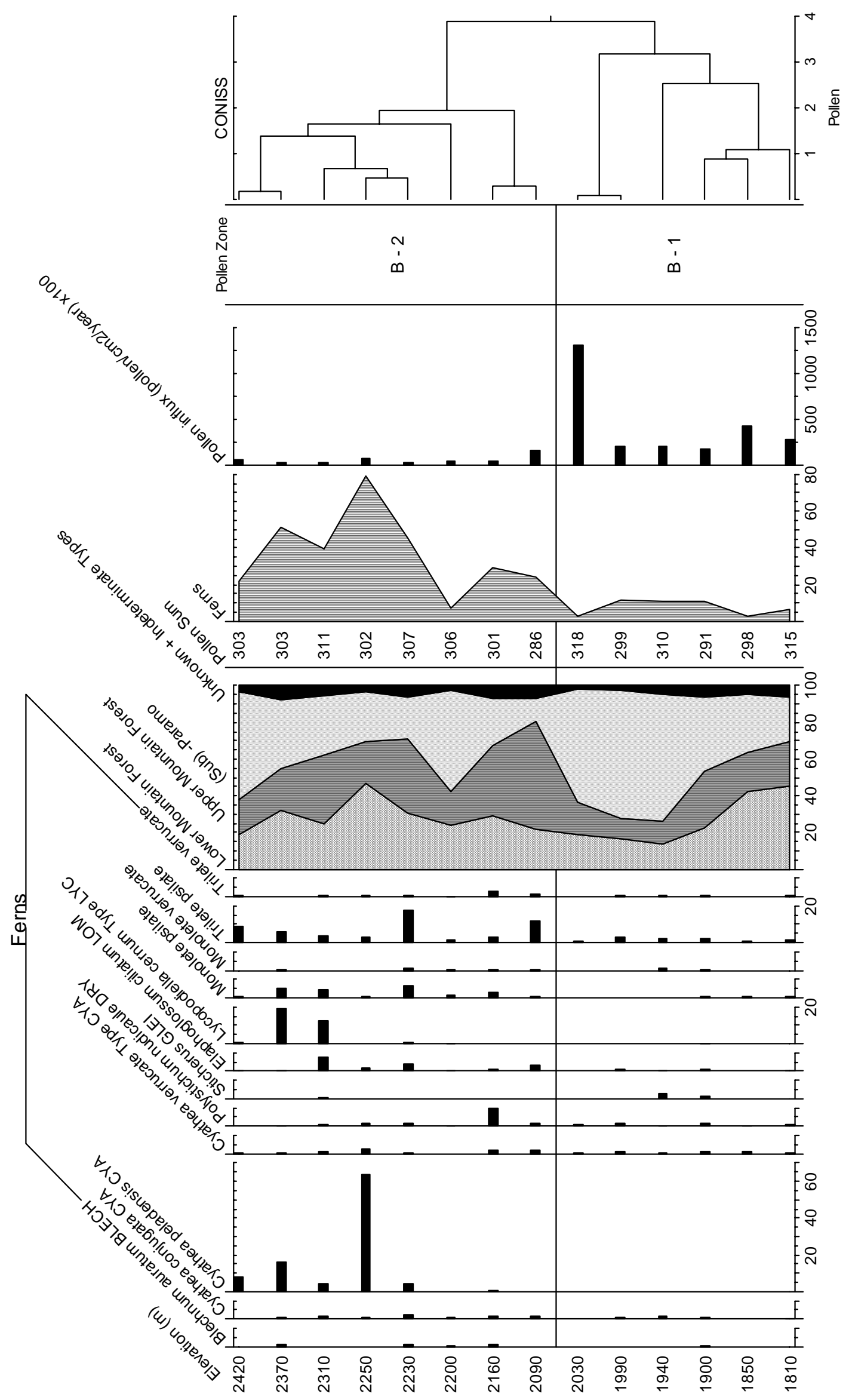

Figure 2.7: Pollen percentage diagram of modern pollen rain spectra (Transect A, 1810-2420 m) from ECSF research area in southeastern Ecuador showing selected spore taxa, sums of ecological groups, the pollen sum, the pollen influx and the CONISS dendrogram. 
(sub)-paramo are common. Melastomataceae (5-45\%), Poaceae (3-12\%), Asteraceae subf. Asterioideae (1-15\%), Clethra (2-10\%), the Baccharis type (1-10\%) and Cyperaceae (1-5\%) are well represented. Centropogon (1-4\%) is represented only in this zone. Fern spores (10$100 \%$ ) shows high values, especially trilete spores such as the tree fern Cyathea peladensis (0-60\%) and Lycopodiella cernum type (0-15\% and 75\% in one sample). Pollen influx (4000$\left.7000 \mathrm{pollen} / \mathrm{cm}^{2} / \mathrm{yr}\right)$ is low in this zone.

Zone A-3 (ca. 2790-3200 m) is marked by the lowest representation of pollen taxa originated from the lower LMF. Moraceae/Urticaceae (3-12\%), Cecropia (2-5\%) and Acalypha (1-5\%) show a relatively low representation. Pollen taxa originated from the UMF show a relatively stable representation in this zone with a strong decrease in the two uppermost samples. Weinmannia (5-30\%), Ilex (1-8\%), Alnus (3-7\%), the Symplocos peruviana type and Hedyosmum (both 1-6\%) are common. Pollen taxa originated from (sub)paramo originated taxa show highest representation in this zone with a strong increase in the two uppermost samples. Cyperaceae (2-65\%), Melastomataceae $(5-13 \%$ and $60 \%$ in the uppermost sample), Poaceae (3-12\%), the Baccharis type (1-12\%), Clethra (2-5\%) and Ericaceae (1-4\%) show a relatively high representation. Valeriana (1-12\%) pollen are only found in the (sub)-paramo zone. Fern spores (5-25\%) are relatively rare. Pollen influx (3000$20,000 \mathrm{pollen} / \mathrm{cm}^{2} / \mathrm{yr}$ ) is low.

\section{Transect B of modern pollen rain (Figs. 2.6 and 2.7)}

Zone B-1 (ca. 1810-2060 m) is marked by a relatively high representation of pollen taxa originated from the LMF. Heliocarpus (20\% in one sample), Alchornea (1-7\%), and Moraceae/Urticaceae (2-6\%) are well represented. Pollen taxa originated from the UMF show lowest representation in this zone. Weinmannia (2-8\%), Eschweilera (1-6\%), Hedyosmum (2$5 \%$ ) and Ilex (1-5\%) show a low representation. Pollen taxa originated from (sub)-paramo shows a relatively high representation. Melastomataceae (1-20\% to 55-62\% in the uppermost part of this zone), Asteraceae subf. Asterioideae (1-9\%), the Baccharis type (1-8\%), the Vernonia type (1-5\%) and the Senecio type (1-4\%) are well represented in this zone. Poaceae $(60 \%)$ show a high representation only in one sample. Fern spores $(5-15 \%)$ are rare. Pollen influx $\left(20,000-40,000 \mathrm{pollen} / \mathrm{cm}^{2} / \mathrm{yr}\right.$ and $130,000 \mathrm{pollen} / \mathrm{cm}^{2} / \mathrm{yr}$ in one sample) is relatively high in this zone.

Zone B-2 (ca. 2060-2420 m) shows a relatively high representation of pollen taxa originated from the LMF. Saurauia (1-5\% and $20 \%$ in one sample), Moraceae/Urticaceae (4-12\%), Hyeronima (1-10\%), Alchornea (1-10\%), Acalypha (2-6\%), Celtis (2-5\%) and Cecropia (1$5 \%)$ are well represented. Pollen taxa originated from the UMF show highest representation in this zone. Myrsine (1-12\% and 35\% in one sample), Purdiaea (1-10\%), Hedyosmum (2$8 \%$ ), Weinmannia (1-8\%), the Symplocos peruviana type (2-6\%), Eschweilera and Alnus (both 2-5\%) are common. Pollen taxa originated from (sub)-paramo shows a relatively high representation. Cyperaceae (5-45\%), Melastomataceae (2-12\%), and Poaceae (3-8\%) are well represented. Fern spores $(10-80 \%)$ show a very high representation, especially trilete spores such as the tree fern Cyathea peladensis $(0-15 \%$ and $65 \%$ in one sample) and Lycopodiella cernum type (0-20\%). Pollen influx (5000-20,000 pollen/ $\left.\mathrm{cm}^{2} / \mathrm{yr}\right)$ is very low in this zone.

\subsection{Interpretation and discussion}

\section{General remarks}

The comparison of recent vegetation, grouped into genera and/or families (Fig. 2.3), with taxa of modern pollen rain (Figs. 2.4 to 2.7) is used to understand the recent vegetation/modern pollen rain relationship. In this context, it has to be considered that the number of species of 
recent vegetation is not strictly representing the number of individuals of this species, but at least it provides important data on the altitudinal distribution of taxa in the area under study. A quantitative analysis of recent vegetation on the complete altitudinal gradient is planed for the ECSF research area and will be available in a few years. The available study of floristic composition of most important trees $(\mathrm{dbh}>5 \mathrm{~cm})$ after Homeier (2008) is restricted to the LMF and UMF.

In interpreting the modern pollen rain data, it has to be considered that some pollen traps are below plant species which might have a strong local input of pollen. Examples for a high value of pollen from single taxa in one pollen trap are found in transect A for the Symplocos peruviana type $(38 \%$ at $2630 \mathrm{~m}$, Fig. 2.4), Cyperaceae $(65 \%$ at $3160 \mathrm{~m}$, Fig. 2.4), Melastomataceae (60\% at 3200 m, Fig. 2.4) and the Lycopodialla cernum type $(75 \%$ at 2480 m, Fig. 2.5) and in transect B for Myrsine (38\% at 2090 m, Fig. 2.6), Melastomataceae (65\% at $1990 \mathrm{~m}$ and $58 \%$ at $2030 \mathrm{~m}$, Fig. 2.6) and Cyathea peladensis (65\% at $2030 \mathrm{~m}$, Fig. 2.7) . This local effect has to be considered by the interpretation.

Pollen transport by wind over longer distances may be lead to wrong interpretation of modern pollen rain data. The comparison of modern vegetation distribution and its pollen rain from the ECSF research area suggest a transport of pollen to higher elevations, leading to an over-representation of lowland taxa (e.g. Acalypha, Cecropia, Trema, Piper, Celtis and Moraceae/Urticaceae) in the UMF and (sub)-paramo vegetation zone. Winds which blow through the Rio San Francisco valley up to higher elevation are probably responsible for the transport of these wind pollinated taxa. Alnus and Pinus do not occur in the ECSF research area (Homeier and Werner 2005). The relatively high representation of Alnus (1-7 \%) and Pinus (0-3 \%) indicates pollen transport from outside the ECSF research area. A Pinus plantation is observed on the opposite slope of the Rio San Francisco valley in about $2 \mathrm{~km}$ distance of ECSF research area. Alnus individuals are also observed at the slopes of the Rio San Francisco valley, as a pioneer of disturbed areas.

Other studies shows that wind transport over longer distances have to taken into account. Results from the Mera site in Ecuadorian Amazonia show that between 2100 and $3400 \mathrm{~m}$, Moraceae/Urticaceae pollen are high represented (until 12\%)(Bush et al. 1990). Surface samples along an elevation gradient between 2800 and $3800 \mathrm{~m}$ at Laguna Baja in northern Peru show an over representation of forest pollen (e.g., Hedyosmum) in paramo samples, attributed to low pollen productivity of local plants at high elevations and by long distance wind transport (Hansen and Rodbell 1995). High representation of Alnus pollen in the superpuna of the Junin area in central Peru between 4400 and $4900 \mathrm{~m}$ depends on wind transport (Hansen et al. 1984). Pollen rain data from the High Plain of Bogota in Colombia between 2600 and $3800 \mathrm{~m}$ show a representation of subandean taxa nearly everywhere in low percentages (Hooghiemstra and Cleef 1984).

Further it has to be considered that the pollen trap at $1940 \mathrm{~m}$ elevation in Transect B (Figs. 2.6 and 2.7) was located in a disturbed area, showing a high occurrence of Poaceae $(65 \%)$ pollen and Sticherus (5\%) fern spores. The fern Sticherus (Gleicheniaceae) is an indicator for disturbed areas (Werner, personal communication).

\section{Recent vegetation/modern pollen rain relationships in the ECSF research area}

Pollen zone A-1 (ca. 1920-2185 m) and pollen zone B-1 (ca. 1810-2060 m) correspond to the LMF vegetation zone (ca. $1800-2100 \mathrm{~m}$ ) and is characterised by a high occurrence of Alchornea, Hyeronima, Heliocarpus, Hedyosmum and Melastomataceae pollen. In comparison with the recent vegetation, Alchornea, Hyeronima and Heliocarpus pollen are originated from the LMF. Melastomataceae pollen occur in all pollen traps of each vegetation zone with the main occurrence in the (sub)-paramo. Studies of floristic composition on ridges and upper slopes of most important trees $(\mathrm{dbh}>5 \mathrm{~cm})$ after Homeier (2008) show a high 
occurrence of Euphorbiaceae (11.8\%) in the LMF, Melastomataceae (17-26\%) is high represented in the LMF and UMF. Fern taxa are frequent in the pollen diagram of Transect A and rare in the pollen diagram of Transect B. This may be due to the somewhat different locations with different condition of humidity.

Pollen zone A-2 (ca. 2185-2790 m) and pollen zone B-2 (from ca. $2060 \mathrm{~m}$ until to the end of the transect at $2420 \mathrm{~m}$ ) correspond to the UMF vegetation zone (ca. $2100-2700 \mathrm{~m}$ ) and is characterised by a high occurrence of Acalypha, Cecropia, Moraceae/Urticaceae, Hedyosmum, Purdiaea, Weinmannia, the Symplocos peruviana type, Myrsine and Melastomataceae pollen. In comparison with the recent vegetation Acalypha, Cecropia and Moraceae/Urticaceae pollen are originated from the LMF, transported by wind. Pollen of Hedyosmum, Purdiaea, Weinmannia, the Symplocos peruviana type and Myrsine are originated in the UMF. Trees $(\mathrm{dbh}>5 \mathrm{~cm})$ of Clethraceae (Purdiaea) $(12.7 \%)$, Clusiaceae $(10.8 \%)$, Rubiaceae (10.2\%), Myrtaceae (9.6\%) and Cunoniaceae (5.9\%) show a high representation in the UMF (Homeier 2008).

The species Purdiaea nutans (Clethraceae) is a small evergreen tree, rarely distributed in mountain forests in northern South America. In the Rio San Francisco valley of southeastern Ecuador, Purdiaea nutans is the dominating tree between 2150 and $2650 \mathrm{~m}$, forming large stands. Purdiaea (an insect pollinated species) amounts up to about $80 \%$ of the individuals, mixed with e.g. Melastomataceae, Hedyosmum and Myrsine as well as (tree)-ferns (Mandl et al. 2008). The low pollen influx in the UMF vegetation zone may belong to a relative decrease of wind pollinated species (high producers), due to the dominance of Purdiaea.

Cluster analyses (CONISS) of terrestrial pollen taxa show a floristic change within the UMF vegetation zone at ca. $2500 \mathrm{~m}$ (Fig. 2.4). This may reflect a topographical aspect, between 2480 and $2520 \mathrm{~m}$ the mountain ridge becomes flat and moist. Otherwise this might reflect the end of the dominance of Purdiaea.

The diversity of fern species more ore less decrease with the elevation (1800-3200 m) in the ECSF research area with a small maximum at ca. $2000 \mathrm{~m}$. The number of individuals, in opposite show a maximum at ca. $2400 \mathrm{~m}$ (Kessler, personal communication). Fern spores (e.g. the Cyathea peladensis and Lycopodiella cernum type) strongly increases in the UMF vegetation zone. This increase may belong to the vegetation composition of the UMF zone. Ferns show the highest number of species in the UMF vegetation zone, related to a strong increase of moisture. Data of horizontal rain and cloud/fog water deposition of 4 sites along the altitudinal gradient show the strongest increase of precipitation between $2270 \mathrm{~m}$ (2403 $\mathrm{mm}$ ) and $2660 \mathrm{~m}$ (5306 mm) (Bendix et al. 2008).

High pollen representation of Poaceae (until 15\%) in the UMF vegetation zone may be depends to the occurrence of forest grasses, with a high pollen production, or by wind transport from disturbed areas around the ECSF research area. Pollen rain data from Mera site in Ecuadorian Amazonia provides a high representation of Poaceae (until 70\%) between 2100 and $2800 \mathrm{~m}$, which may be a result of local pollen input to moss pollsters and presumably represents a forest grass (Bush et al. 1990). Surface samples from the Junin area in central Peru show high pollen representation of Poaceae (40-60\%) in the forest zones (until $3200 \mathrm{~m}$ ) than in the shrub land above. Agricultural disturbance may be responsible for that (Hansen et al. 1984).

Pollen zone A-3 (ca. 2790-3200 m) corresponds to the (sub)-paramo vegetation zone (ca. 2700-3200 m) and is characterised by a high occurrence of Moraceae/Urticaceae, Weinmannia, Clethra, Melastomataceae, Ericaceae, Poaceae and Cyperaceae pollen. In comparison with recent vegetation Moraceae/Urticaceae pollen are originated in lower elevations (Wind transport), Weinmannia pollen are originated from the UMF as well as the (sub)-paramo zone. Pollen of Clethra, Melastomataceae, Ericaceae, the Baccharis type, Poaceae and Cyperaceae pollen are originated from this vegetation zone. 
A marked change of the floristic composition is shown at ca. $2790 \mathrm{~m}$, reflecting the modern tree line in the (ECSF) research area. This floristic change is indicated by an increase of (sub)-paramo pollen and a decrease of LMF and UMF pollen and fern spores.

A second marked change of the floristic composition is shown at ca. $3135 \mathrm{~m}$. The strong increase of (sub)-paramo pollen, coupled with a strong decrease of LMF and UMF pollen, reflect the border between subparamo and paramo vegetation zone. Valeriana and Jamesonia are typical species of the paramo zone, showing a higher occurrence at elevations above ca. $3050 \mathrm{~m}$. Due to the end of the transect at $3200 \mathrm{~m}$, further transect studies in elevations higher than $3200 \mathrm{~m}$ are needed to study the transition between subparamo and paramo.

In general, the altitudinal vegetation gradient of lower- and upper mountain forest and (sub)-paramo of the ECSF area is well reflected in the modern pollen rain data. A high number of taxa of modern pollen rain correspond to the altitudinal distribution of genera and/or families of the modern vegetation. The dendrogram provided by CONISS verify this zonation for the modern pollen rain taxa with only a little deviation, indicating that modernas well as fossil palynological studies can be used well to reconstruct vegetation development on an altitudinal gradient. Important key taxa for the LMF are Alchornea, Hyeronima and Heliocarpus, for the UMF Purdiaea, Clusia, Myrsine, Myrtaceae, Podocarpaceae, Rubiaceae, the Symplocos peruviana type, Cyathea spp. and Elaphoglossum, and for the (sub)-paramo Clethra, Cyperaceae, Ericaceae, the Baccharis type, Valeriana and Jamesonia. The LMF taxa Acalypha, Cecropia, Piper and Moraceae/Urticaceae show high occurrences in all vegetation units. The UMF taxa Hedyosmum and Eschweilera show their main occurrence in the LMF, Weinmannia is highest represented in the (sub)-paramo vegetation unit. The (sub)-paramo taxa Melastomataceae and Poaceae are represented in all vegetation units.

Pollen rain data of the Madre de Dios River in southeastern Peru (240 to $3500 \mathrm{~m}$ ) show that modern pollen assemblages reflect local floras and provide a characteristic pollen spectrum for each elevation. As expected forest turnover along an elevational gradient provided a strong correlation with changing pollen spectra. Pollen of Hedyosmum, Alnus, Poaceae and Combretaceae/Melastomataceae are abundant between 1600 and $2000 \mathrm{~m}$. Alnus pollen is most abundant, and Poaceae becomes rare, between 2000 and $2700 \mathrm{~m}$. Above $2700 \mathrm{~m}$, Asteraceae, Poaceae, Polylepis, the Muehlenbeckia type and Myrsine pollen are dominant (Weng et al. 2004).

The vegetation zonation after Van der Hammen (1974), given for the tropical Cordillera Oriental fixed the Subandean forest at an elevation from ca. 1000 to $2500 \mathrm{~m}$ (equivalent to LMF between ca. 1300 and $2100 \mathrm{~m}$ ), the Andean forest from ca. 2500 to $3500 \mathrm{~m}$ (equivalent to UMF between ca. 2100 and $2700 \mathrm{~m}$ ) and the (sub)-paramo from ca. 3500 to $4200 \mathrm{~m}$. The recent vegetation units (Subandean forest, Andean forest, paramo and super paramo) are reflected in the pollen rain data, from the Sumapaz area, eastern slope of the Central Cordillera, Colombia (1120 and $4250 \mathrm{~m}$ ), with a high input of extraneous pollen (Melief 1985).

The low elevation of vegetation zones, as well as the low modern tree line in the (ECSF) research area (ca. $2790 \mathrm{~m}$ ) in comparison with other parts of the northern Andes, may be result of the so-called Andean depression. The modern tree line in central Ecuador is at ca. $3400 \mathrm{~m}$ (La Libertad), at ca. $3500 \mathrm{~m}$ (Atillo) and in northern Ecuador at ca. $3600 \mathrm{~m}$ (Guandera). At the El Tiro-Pass, $10 \mathrm{~km}$ west of (ECSF) research area, the tree line is at ca. $2800 \mathrm{~m}$, this is about 600-800 m lower (Bader 2007). In the Junin area at the east Andean slope of central Peru the border between Andean forest and subpuna vegetation is at about $3100 \mathrm{~m}$ (Hansen et al. 1984). At Laguna Baja in the Cordillera Oriental of Peru the border between wet mountain forest and paramo vegetation is at about $3400 \mathrm{~m}$ (Hansen and Rodbell 1995). 


\subsection{Summary and conclusions}

In studying the recent vegetation/modern pollen rain relationship in the ECSF research area (Podocarups National Park region), southeastern Ecuador, we answered following main research questions:

(1) How is the recent vegetation reflected in the modern pollen rain spectra? A relatively high number of pollen taxa correspond to the altitudinal distribution of genera and/or families of the modern vegetation. Wind dispersal is responsible for a high occurrence of the lower mountain forest taxa (e.g. Moraceae/Urticaceae, Piper and Acalypha) in the upper mountain forest and/or (sub)-paramo vegetation zone.

(2) Can the different vegetation units lower and upper mountain forest and (sub)-paramo separated by pollen data? The altitudinal vegetation gradient is well reflected in the modern pollen rain data. The dendrogram provided by CONISS verify this zonation for the modern pollen rain taxa with only a little deviation, indicating that modern- as well as fossil palynological studies can be used well to reconstruct vegetation development on an altitudinal gradient.

(3) Are there any key taxa for the different vegetation units? Important key taxa for the LMF are Alchornea, Hyeronima and Heliocarpus, for the UMF Purdiaea, Clusia, Myrsine, Myrtaceae, Podocarpaceae, Rubiaceae, the Symplocos peruviana type, Cyathea spp. and Elaphoglossum, and for the (sub)-paramo Clethra, Cyperaceae, Ericaceae Baccharis type, Valeriana and Jamesonia.

(4) How is the tree line reflected in the modern pollen rain data? The modern tree line in the research area at ca. $2790 \mathrm{~m}$, is reflected by an increases of (sub)-paramo taxa (e.g. Cyperaceae, the Baccharis type, Valeriana and Jamesonia) and a decrease mountain forest taxa (e.g. Clusia, Myrsine and the Symplocos peruviana type).

Acknowledgements: Felix Matt (research station leader) is thanked for his logistical support and for his information about the study region. Thanks are also to Jürgen Homeier for using his species lists and his collected flower samples and to Peter von Schnakenberg and Achim Bräuning for collecting the pollen traps. The project FOR 402/D1 (Vegetation-, climate- and fire dynamics in the Podocarpus National Park region) is kindly funded by the Deutsche Forschungsgemeinschaft (DFG). 


\title{
3. Late Holocene environmental change and human impact inferred from Laguna Zurita multi-proxi record and three soil monoliths in the southeastern Ecuadorian Andes
}

\section{Vegetation History and Archaeobotany (in review)}

\author{
Holger Niemann, Hermann Behling
}

Department of Palynology and Climate Dynamics, Albrecht-von-Haller-Institute for Plant Sciences,University of Göttingen, Untere Karspüle 2, 37073 Göttingen, Germany

\begin{abstract}
In order to study stability and dynamics of mountain rainforest and paramo ecosystems, the Holocene climate and fire variability and human impact we present a high resolution multi-proxy record from Laguna Zurita $(2590 \mathrm{~m})$, combined with three soil monoliths, spanning an altitudinal gradient between 1990 and 3200 m, in the upper Rio San Francisco valley, southeastern Ecuadorian Andes.

XRF data from Laguna Zurita sediment core shows wet climatic conditions before ca. 790 cal yr BP and between ca. 790 and 480 cal yr BP dryer climatic conditions. The modern mountain forest vegetation established after ca. 750 cal yr BP. Three of four radiocarbon dated pollen records show a marked change in floristic composition between ca. 980 to 360 cal yr BP. Past fires have markedly influenced the floristic composition of the mountain rainforest ecosystem. Frequent fires, together with the relatively high occurrence of grasses and some corn plantations, document past human activities. The reduction and/or absence of human activities may be a result of social unrest. After the reduction and/or absence of human influence, the forest starts to regenerate in the upper Rio San Francisco valley.
\end{abstract}

Keywords: Ecuador, mountain rainforest, pollen analysis, climate change, human impact, XRF-scanning 


\subsection{Introduction}

The Ecuadorian Andes harbour the most species rich ecosystems on earth (Barthlott et al. 2005). Despite its high biodiversity huge areas have been strongly affected during the last decades in particular. Natural vegetation regeneration and sustainable management is urgently needed as well as conservation of less degraded areas.

In order to study the highly diverse mountain ecosystems in southeastern Ecuador, extended research has been carried out in the framework of the "Deutsche Forschungsgemeinschaft" (DFG) research group "Tropical Mountain Ecosystems" focusing on Podocarups National Park (Beck et al. 2008a). Currently (2007-2010) more than 25 different research groups are working in the Estacion Cientifica San Francisco (ECSF) research area. Palaeoecological work analysing in total more than 10 different lake, peat and soil cores in the Podocarpus National Park region started in 2005 (Niemann and Behling 2008c; Niemann et al. 2007). This palaeoecological information is needed to understand the development and dynamics of modern ecosystems for proper management and conservation.

So far, a few palaeoenvironmental records are available from southern Ecuador and neighbouring regions (Fig. 3.1). For example from Lake Ayauch in the southeastern part of Ecuadorian Amazonia (Bush and Colinvaux 1988), from Rio Napo in the northwestern Amazon basin of Ecuador (Colinvaux et al. 1988a), from Lake Yambo at the Inter-Andean Plateau of Ecuador (Colinvaux et al. 1988b), from the Colombian Cauca Valley (Berrio et al. 2002), from Huascaran (ice cores) in the central Peruvian Andes (Thompson et al. 2003), from Lake Titicaca and the surrounding Bolivian-Peruvian Altiplano (Binford et al. 1997) and from the Cuzco region in Peru (Chepstow-Lusty et al. 2003).

In this study we want to address following main questions: (1) How stable was the mountain rainforest of the ECSF research area during the late Holocene and is the vegetation natural? (2) Played fire a role in mountain ecosystems during the past? (3) Was there any human impact in the ECSF research area and Rio San Francisco valley during the late Holocene?

\subsection{Site description}

\section{Location}

The Andes of southern Ecuador and northern Peru include the so-called Andean depression (Depression de Giron-Cuenca in Ecuador and Huancabamba in Peru). The main peaks of the mountains in this region reach up to about $4000 \mathrm{~m}$. Active volcanoes are absent (Richter and Moreira-Munoz 2005). The southern Cordillera Real is mainly built up by the geologic unit of the "Zamora series", consisting of Palaeozoic metamorphic rocks of widely varying metamorphic grade. Local bedrock is dominated by semipelites, quartzites and black phylites with some granitic intrusions (Litherland et al. 1994).

The study area (Fig. 3.1) is located on the eastern slope of the eastern Cordillera (Cordillera Real) between the city of Loja $(2200 \mathrm{~m})$ and the city of Zamora $(1000 \mathrm{~m})$, north of the Podocarpus National Park in the E-W exposed upper Rio San Francisco valley.

The ECSF research area $\left(3^{\circ} 58^{\prime} 30^{\prime \prime} \mathrm{S}, 079^{\circ} 4^{\prime} 25^{\prime \prime} \mathrm{W}\right)$, is located about $15 \mathrm{~km}$ east of Loja, next to the small village of Sabanilla on an about $5 \mathrm{~km}$ long mountain ridge system in north-south orientation, between 1800 and $3200 \mathrm{~m}$ elevation and covers an area of about 1100 ha. The location of three soil monoliths is given in Figure 3.2.

Laguna Zurita (Fig. 3.2), at 2590 m elevation ( $3^{\circ} 58^{\prime} 28.8^{\prime \prime} \mathrm{S}, 079^{\circ} 07^{\prime} 03.4^{\prime \prime} \mathrm{W}$ ) is exposed on a flat mountain ridge in a small depression about $200 \mathrm{~m}$ above the old road from Loja to Zamora. The distance to Loja is about $10 \mathrm{~km}$. The size of the lake is about $2000 \mathrm{~m}^{2}$ and the depth in the middle part is 3-4 m. 


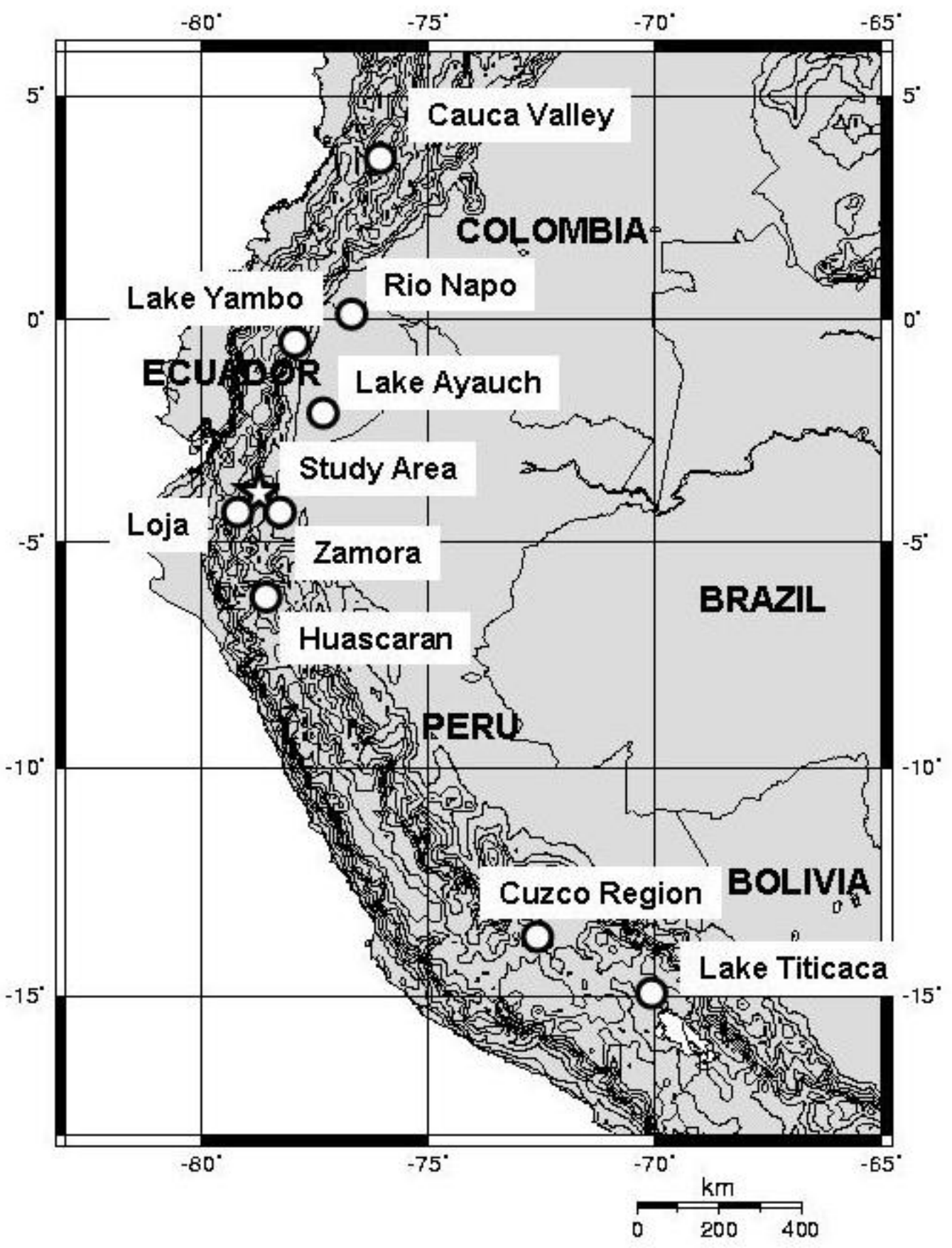

Figure 3.1: Map of central northwestern tropical South America, showing the study site (star) and other locations discussed in the text (circles). The map was created under using OMC (www.aquarius.geomar.de).

\section{Modern vegetation}

The vegetation of the southeastern Ecuadorinan Andes is mainly related to the altitudinal gradient. The different vegetation units were described for the Podocarpus National park region:

The lower mountain rainforest (LMF) in found between ca. 1800-2150 m with an extremely diverse, 2-storied tree stratum is composed of a numerous $20-35 \mathrm{~m}$ tall tree species. Characteristic species are e.g., Alzetea verticillata (Alzataceae), Graffenrieda miconioides (Melastomataceae) and Myrcianthes sp. (Myrtaceae). The upper mountain rainforest (UMF) between ca. 2100-2750 m; replaced by a low monotypic formation with one tree stratum between 5-10 m, rarely up to $15 \mathrm{~m}$ tall. Characteristic trees are Purdiaea nutans (Cyrillaceae), 


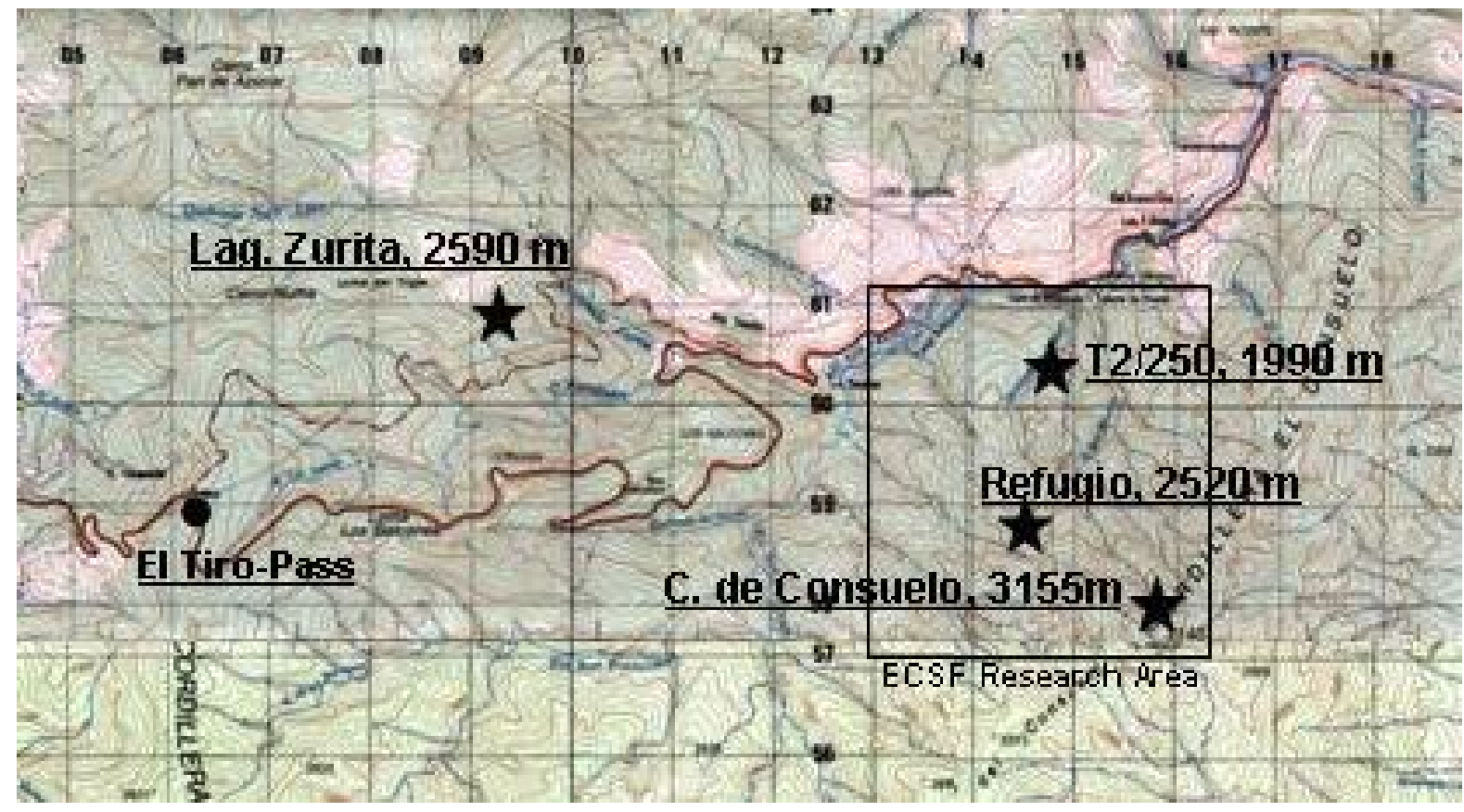

Figure 3.2: Detailed map of the upper Rio San Francisco valley (Mapa Topográfico del Ecuador 1:50.000, Hoja Loja Sur 3781- I) showing the location of the ECSF research area (square), El Tiro-Pass (dot), Laguna Zurita and the three soil monoliths (stars).

Myrica pubescens (Myricaceae) and Myrsine andina (Myrsinaceae) (Bussmann, 2001, 2005; Lozano et al. 2003). Between ca. 2800-3100 m, subparamo is present, characterised by Puya nitida (Bromeliaceae), Brachyotum rotundifolium (Melastomataceae) and Oritrophium peruvianum (Asteraceae). The shrubs and herbs grow up to $1 \mathrm{~m}$ height, individual shrub species can be 2-3 m tall (Lozano et al. 2003). The paramo is present at elevations from ca. 3100 to $3400 \mathrm{~m}$ and is characterised by species such as Arcytophyllum setosum (Rubiaceae), Blechnum cordatum (Blechnaceae), Puya maculate (Bromeliaceae) and Gynoxis buxifolia (Asteraceae) (Lozano et al. 2003).

The modern tree line in central Ecuador is at ca. $3400 \mathrm{~m}$ (La Libertad) and ca. $3500 \mathrm{~m}$ (Atillo) and in northern Ecuador at ca. $3600 \mathrm{~m}$ (Guandera). At the El Tiro-Pass, $10 \mathrm{~km}$ west of (ECSF) research area, the modern tree line is at ca. $2800 \mathrm{~m}$, this is about $600-800 \mathrm{~m}$ lower (Bader 2007).

\section{Climate}

The climate of Ecuador is dominated by the tropical trade wind regime which is well established in the mid- and higher troposphere, with strong easterlies all over the year. The surface wind field is locally and regionally modified by the complex topography of the Andes and the thermal land-sea contrast at the Pacific coast. The south-eastern part of the country encompassing the ECSF research area is also mainly influenced by easterlies, but westerlies occasionally occur especially in austral summer. The main rainy season lasts from April to August even if rainfall is high all through the year (Beck et al. 2008b). As part of the so-called Andean depression, all summits in the southern Ecuadorian Andes are below the snowline.

The eastern Andean mountains form a division that separates the moist eastern slopes of the Andes from the dry inner-Andean basins (e.g., the Loja- and Catamayo Basin). Between the eastern slopes of the eastern Cordillera and the dry valley of Catamayo, which are only $70 \mathrm{~km}$ apart, annual rainfall rates drop from over $4000 \mathrm{~mm}$ to $300 \mathrm{~mm}$ (Bendix et al. 2004).

The precipitation patterns at the ECSF research area show a strong altitudinal gradient, with an increase of precipitation from the valley bottom $(1800 \mathrm{~m}, 2297 \mathrm{~mm})$ to summit region 
(3200 m, $6701 \mathrm{~mm}$ ) (Bendix et al. 2008). The average precipitation rate near the El Tiro-Pass $(2880 \mathrm{~m}), 10 \mathrm{~km}$ west of the ECSF research area is about $3500 \mathrm{~mm} / \mathrm{yr}$ (Emck 2007).

\subsection{Material and methods}

The about $50 \mathrm{~cm}$ long soil monoliths were collected at three different altitudes in the ECSF research area by excavation. The soil monoliths were taken on a small plateau at $1990 \mathrm{~m}$ (T2/250), on a flat mountain ridge at $2520 \mathrm{~m}$ (Refugio) and in a small depression next to the summit at $3155 \mathrm{~m}$ (Cerro de Consuelo). The monoliths were stored in splitted PVC tubes, wrapped with plastic film and stored under dark and cold $\left(+4{ }^{\circ} \mathrm{C}\right)$ conditions before processing.

The $69 \mathrm{~cm}$ long sediment core from Laguna Zurita was raised with a Livingstone pistoncorer near the central position of the lake ( $3.5 \mathrm{~m}$ water depth) from two inflatable rubber rafts. The core was retained in the tube and stored under dark and cold $\left(+4{ }^{\circ} \mathrm{C}\right)$ conditions before processing.

In total, nine subsamples (soil organic matter, bulk and charcoal fragments) were taken for Accelerator Mass Spectrometer (AMS) radiocarbon dating. Radiocarbon ages were calibrated with CalPal (Weninger et al. 2004).

From the three soil monoliths, in total 73 subsamples $\left(0.25 \mathrm{~cm}^{3}\right)$ were taken at $2 \mathrm{~cm}$ intervals. From Laguna Zurita sediment core 24 subsamples $\left(0.25 \mathrm{~cm}^{3}\right)$ were taken at $4 \mathrm{~cm}(2$ $\mathrm{cm}$ at the lowermost core section) intervals. All samples were processed with standard methods (Faegri and Iverson 1989). Before treatment, exotic Lycopodium spores were added to each sample for calculation of pollen concentration (pollen/ $\mathrm{cm}^{3}$ ) and/or influx (pollen $/ \mathrm{cm}^{2} / \mathrm{yr}$ ). About 300 pollen grains were counted for each sample. The pollen sum includes tree, shrub and herb pollen and excludes aquatic pollen taxa and fern spores. Pollen of Cyperaceae also was excluded in the pollen sum of the Laguna Zurita record. Pollen identification relied on the reference collection from the second author with about 3000 neotropical species and literature (Behling 1993; Hooghiemstra 1984) and on a reference collection with about 300 species collected during the fieldwork and from the herbarium of the ECSF research station.

The ecological grouping of the identified pollen taxa into lower and upper mountain forest and (sub)-paramo follows available data in the literature (Homeier and Werner 2005; Lozano et al. 2003). Pollen and spore data are presented in pollen diagrams as percentages of the pollen sum. Carbonized particles $(10-150 \mu \mathrm{m})$ were counted on pollen slides and presented as concentration (pollen $/ \mathrm{cm}^{3}$ ) and/or influx (particles $/ \mathrm{cm}^{2} / \mathrm{yr}$ ). The software TILIA, TILIAGRAPH and CONISS were used to plot the pollen and spore data (Grimm 1987). Cluster analysis (CONISS) of terrestrial pollen and spore taxa produces a dendrogram which help to identify the pollen zones.

Non-destructively magnetic susceptibility ( $\kappa)$ scanning was performed on split core of Laguna Zurita with a Bartington MS2F point sensor at $1 \mathrm{~cm}$ resolution. Also nondestructively, an Avaatech XRF-scanner provided semi-quantitative analyses of Al, Si, S, K, $\mathrm{Ca}, \mathrm{Ti}, \mathrm{Mn}$ and Fe (Richter et al. 2006; Tjallingii et al. 2007) in $1 \mathrm{~cm}$ depth intervals. Values are given in total counts (cnts).

\subsection{Results}

\section{Stratigraphy and chronology}

Site specific data of the three soil monoliths from ECSF research area and the Laguna Zurita sediment core are given in Table 3.1. 


\begin{tabular}{lllccc}
\hline Record name & Material & Vegetation zone & Elevation & Length & $\begin{array}{c}\text { Number of } \\
\text { ident. taxa }\end{array}$ \\
& & & & & \\
\hline ECSF-T2/250 & Soil monolith & LMF & $1990 \mathrm{~m}$ & $48 \mathrm{~cm}$ & 91 \\
ECSF-Refugio & Soil monolith & UMF & $2520 \mathrm{~m}$ & $44 \mathrm{~cm}$ & 72 \\
ECSF-C. de Consuelo & Soil monolith & (Sub) -paramo & $3155 \mathrm{~m}$ & $49 \mathrm{~cm}$ & 87 \\
Laguna Zurita & Sediment core & UMF & $2590 \mathrm{~m}$ & $69 \mathrm{~cm}$ & 101 \\
\hline
\end{tabular}

Table 3.1: Site specific data of the three soil monoliths from the ECSF research area and Laguna Zurita sediment core.

The $49 \mathrm{~cm}$ long soil monolith from ECSF-Cerro de Consuelo consists of brown organic material with roots $(0-6 \mathrm{~cm}$ depth). In the transition zone $(6-19 \mathrm{~cm})$ the organic matter content decreases. The AMS radiocarbon dates suggest a hiatus for the uppermost core part. The lower part of the core consists of grey silty clay $(19-49 \mathrm{~cm})$. The $44 \mathrm{~cm}$ long soil monolith from ECSF-Refugio consists of brown organic material with roots $(0-33 \mathrm{~cm}$ depth) and decomposed dark brown organic rich material $(33-44 \mathrm{~cm})$. The $48 \mathrm{~cm}$ long soil monolith from ECSF-T2/250 consists of brown organic material with roots (0-17 cm depth) and decomposed dark brown organic rich material $(17-48 \mathrm{~cm})$. The $69 \mathrm{~cm}$ long sediment core from Laguna Zurita consists of brown fine detritus mud $(0-33 \mathrm{~cm})$ and compacted light brown organic rich material with clay $(33-69 \mathrm{~cm})$.

In total, nine AMS radiocarbon dates are available (Tab. 3.2). Seven for the three soil monolith of the ECSF research area and two for the Laguna Zurita sediment core. Due to the absence of macroscopic charcoal in the upper part of the soil monoliths of ECSF-Refugio and ECSF-T2/250, soil organic matter was dated. The dated material was contaminated by recent organic material (decomposed rootlets) and cannot be used for the chronology. Dating of fractions of soil organic matter obtained by alkali-acid extraction is promising, but which fraction renders the most accurate $14 \mathrm{C}$ dates is still subject to debate (Tonneijck et al 2006).

However, dated charcoal and bulk samples can be used for calculation. For the soil monoliths of ECSF-Refugio and ECSF-T2/250 only one date is valuable for the chronology. Extrapolation of the AMS radiocarbon dates provides core ages of ca. $1350 \mathrm{cal} \mathrm{yr}$ BP for ECSF-Cerro de Consuelo, ca. 1050 cal yr BP for ECSF-Refugio, ca. 1250 cal yr BP for ECSF-T2/250 and ca. 1380 cal yr BP for Laguna Zurita.

\begin{tabular}{|c|c|c|c|c|c|c|}
\hline Core name & $\begin{array}{l}\text { Laboratory } \\
\text { code }\end{array}$ & Dated material & $\begin{array}{l}\text { Core } \\
\text { depth }\end{array}$ & ${ }^{14} \mathrm{C}$ yr BP & cal yr BP & $A D$ \\
\hline ECSF-T2/250 & Erl-9448 & Charcoal & $33 \mathrm{~cm}$ & $915 \pm 38$ & 845 (792-897) & 1105 \\
\hline ECSF-T2/250 & Erl-8901 & Soil org. matter & $21 \mathrm{~cm}$ & $-708 \pm 42$ & & \\
\hline ECSF-T2/250 & Erl-8902 & Soil org. matter & $46 \mathrm{~cm}$ & $-533 \pm 48$ & & \\
\hline ECSF-Refugio & Erl-8377 & Charcoal & $34.5 \mathrm{~cm}$ & $854 \pm 45$ & $798(729-866)$ & 1152 \\
\hline ECSF-Refugio & Erl-8900 & Soil org. matter & $17 \mathrm{~cm}$ & $-602 \pm 34$ & & \\
\hline ECSF C. de Consuelo & Erl-8803 & Charcoal & $18 \mathrm{~cm}$ & $1016 \pm 53$ & $915(848-981)$ & 1035 \\
\hline ECSF C. de Consuelo & Erl-8904 & Bulk sample & $36 \mathrm{~cm}$ & $1236 \pm 47$ & $1172(1102-1241)$ & 778 \\
\hline Lag. Zurita & Erl-8376 & Bulk sample & $33 \mathrm{~cm}$ & $395 \pm 43$ & 425 (353-497) & 1525 \\
\hline Lag. Zurita & Erl-11031 & Bulk sample & $51 \mathrm{~cm}$ & $1015 \pm 46$ & $912(853-970)$ & 1038 \\
\hline
\end{tabular}

Table 3.2: AMS-radiocarbon dates, calibrated ages and ages AD of the three soil monoliths from ECSF research area and Laguna Zurita sediment core. 


\section{Description of the pollen diagram of ECSF - Cerro de Consuelo (Fig. 3.3)}

Zone C-1 (49-40 cm, older than $1200 \mathrm{cal}$ yr BP (750 AD), 5 subsamples) shows a relatively stable representation of arboreal pollen (AP) and non arboreal pollen (NAP). AP of Weinmannia (15-30\%), Melastomataceae (15-20\%), Hedyosmum, Piper, Podocarpaceae and Moraceae/Urticaceae (all 3-8\%) are well represented. Ericaceae (2-10\%), Ilex and Myrsine (both 3-8\%) shows highest values during this period. NAP, especially Poaceae $(12-20 \%)$ is well represented. Fern spores show no marked change in the record. Pollen concentration $\left(60,000-120,000\right.$ grains $\left./ \mathrm{cm}^{3}\right)$ is relatively high and charcoal concentration $(100,000-600,000$ particles $\left./ \mathrm{cm}^{3}\right)$ is low. Pollen influx $\left(3500-8000\right.$ grains $\left./ \mathrm{cm}^{2} / \mathrm{yr}\right)$ is high and charcoal influx (500-3500 particles $/ \mathrm{cm}^{2} / \mathrm{yr}$ ) is relatively low.

Zone C-2 (40-20 cm, ca. 1200-920 cal yr BP, ca. 750-1030 AD, 10 subsamples) is marked by a stable representation of AP and NAP. AP of Weinmannia (20-30\%), Melastomataceae (20-25\%), Piper, Myrsine and Moraceae/Urticaceae (all 3-8\%) shows relatively high values. NAP, especially Poaceae (10-12\%) is well represented. Pollen concentration (80,000-230,000 grains $/ \mathrm{cm}^{3}$ ) and charcoal concentration (1-1.8 million particles $\left./ \mathrm{cm}^{3}\right)$, as well as pollen influx (5000-15,000 grains $/ \mathrm{cm}^{2} / \mathrm{yr}$ ) and charcoal influx (5000-12,000 particles $/ \mathrm{cm}^{2} / \mathrm{yr}$ ) are highest during this period.

Zone C-3 (20-0 cm, younger than 920 cal yr BP (1030 AD), 10 subsamples) shows less AP and higher values of NAP as the preceding zone. AP of Weinmannia (20-28\%), Melastomataceae (20-30\%), Moraceae/Urticaceae (5-10\%) and Piper (3-8\%) are frequent. NAP, especially Poaceae (12-22\%) shows high values during this period. Pollen concentration $\left(50,000-200,000\right.$ grains $\left./ \mathrm{cm}^{3}\right)$ is relatively high and charcoal concentration $(200,000-800,000$ particles $/ \mathrm{cm}^{3}$ ) relatively is low. Pollen influx (500-4000 grains $/ \mathrm{cm}^{2} / \mathrm{yr}$ ) and charcoal influx (under 1000 particles $/ \mathrm{cm}^{2} / \mathrm{yr}$ ) are lowest in this zone.

\section{Description of the pollen diagram of ECSF - Refugio (Fig. 3.4)}

Zone R-1 (44-38 cm, older than $800 \mathrm{cal}$ yr BP (1150 AD), 3 subsamples) is marked by an increase of AP and a decrease of NAP. AP of Weinmannia (15-20\%), Melastomataceae, Pudiaea (both 8-10\%), Ilex, Hedyosmum, Podocarpaceae and Myrtaceae (all 5-8\%) shows relatively high values. NAP, especially Poaceae $(8-12 \%)$ is well represented. Trilete fern spores especially the Cyathea conjugata type (5-15\%) decreases. Pollen concentration $\left(180,000-600,000\right.$ grains $\left./ \mathrm{cm}^{3}\right)$ is high and charcoal concentration $\left(<50,000\right.$ particles $\left./ \mathrm{cm}^{3}\right)$ low during this period.

Zone R-2 (38-33 cm, older than 800 cal yr BP (1150 AD), 3 subsamples) shows a stable representation of AP and NAP. AP of Weinmannia (20\%), Pudiaea (8-15\%), Ilex, Hedyosmum, Piper, Myrsine, Podocarpaceae and Myrtaceae (all 5-8\%) are relatively frequent during this period. Melastomataceae increase from10 up to $30 \%$. NAP, especially Poaceae $(5-8 \%)$ is relatively rare. A single pollen grain of Zea mays is found in one sample. Trilete fern spores strong decreases. Pollen concentration (260,000-600,000 grains $\left./ \mathrm{cm}^{3}\right)$ and charcoal concentration $\left(150,000-600,000\right.$ particles $\left./ \mathrm{cm}^{3}\right)$ is highest in this zone.

Zone R-3 (33-0 cm, younger than 800 cal yr BP (1150 AD), 17 subsamples) is marked by a relatively stable representation of AP and NAP. AP of Weinmannia (20-35\%) and Melastomataceae (18-30\%), Pudiaea (7-15\%), Moraceae/Urticaceae (3-10\%), Piper (4-6\%), Hedyosmum and Podocarpaceae (both $0-7 \%$ ) are relatively frequent. NAP, especially Poaceae $(4-11 \%)$ is relatively rare during this period. A single pollen grain of Zea mays is found in this zone. Monolete and trilete fern spores, especially the Blechnum auratum type (1-25\%), strong increases at the end of this period. Pollen concentration $\left(<160,000\right.$ grains $\left./ \mathrm{cm}^{3}\right)$ and charcoal concentration $\left(<80,000\right.$ particles $\left./ \mathrm{cm}^{3}\right)$ is lowest. 


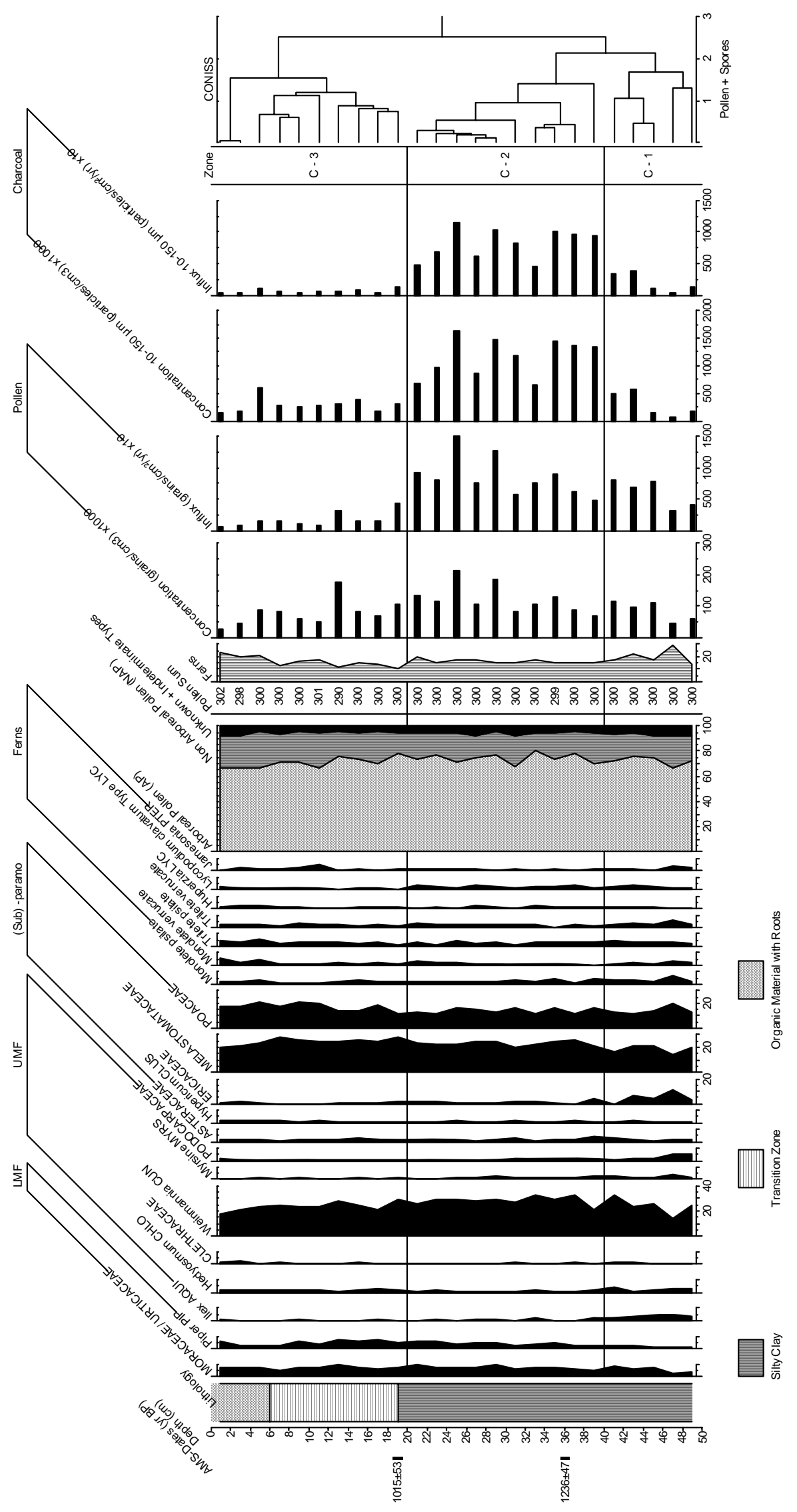

Figure 3.3: Pollen percentage diagram of the soil monolith from ECSF Cerro de Consuelo (3155 m elevation) showing the AMS radiocarbon dates (yr BP), the lithology, selected pollen and spore taxa grouped into lower mountain forest (LMF), upper mountain forest (UMF) and (sub)-paramo, sums of ecological groups, the pollen sum, pollen and charcoal concentration and influx, the pollen zones and the CONISS dendrogram. 


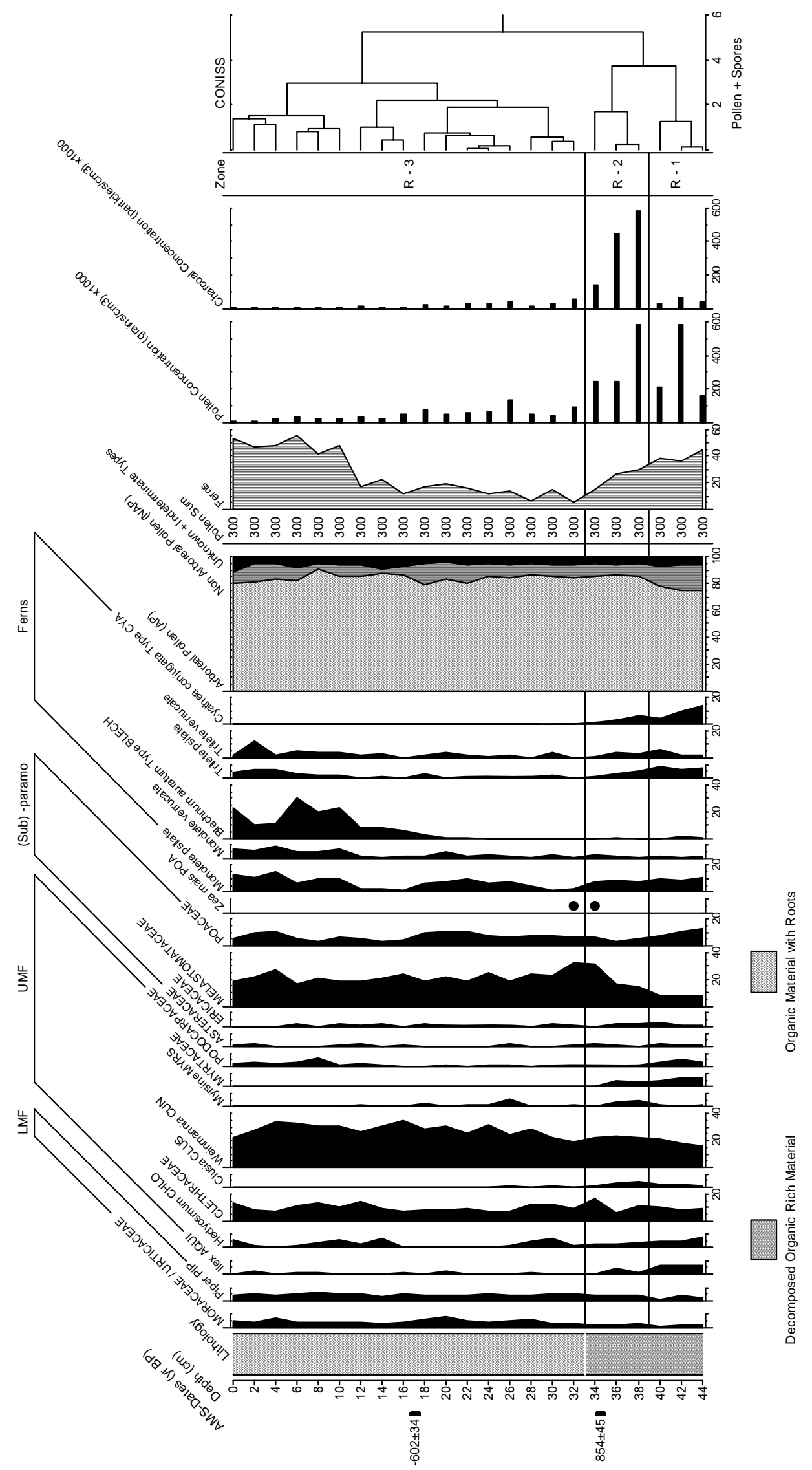

Figure 3.4: Pollen percentage diagram of the soil monolith from ECSF Refugio ( $2520 \mathrm{~m}$ elevation) showing the AMS radiocarbon dates (yr BP), the lithology, selected pollen and spore taxa, grouped into lower mountain forest (LMF), upper mountain forest (UMF) and (sub)-paramo, sums of ecological groups, the pollen sum, pollen and charcoal concentration, the pollen zones and the CONISS dendrogram. 


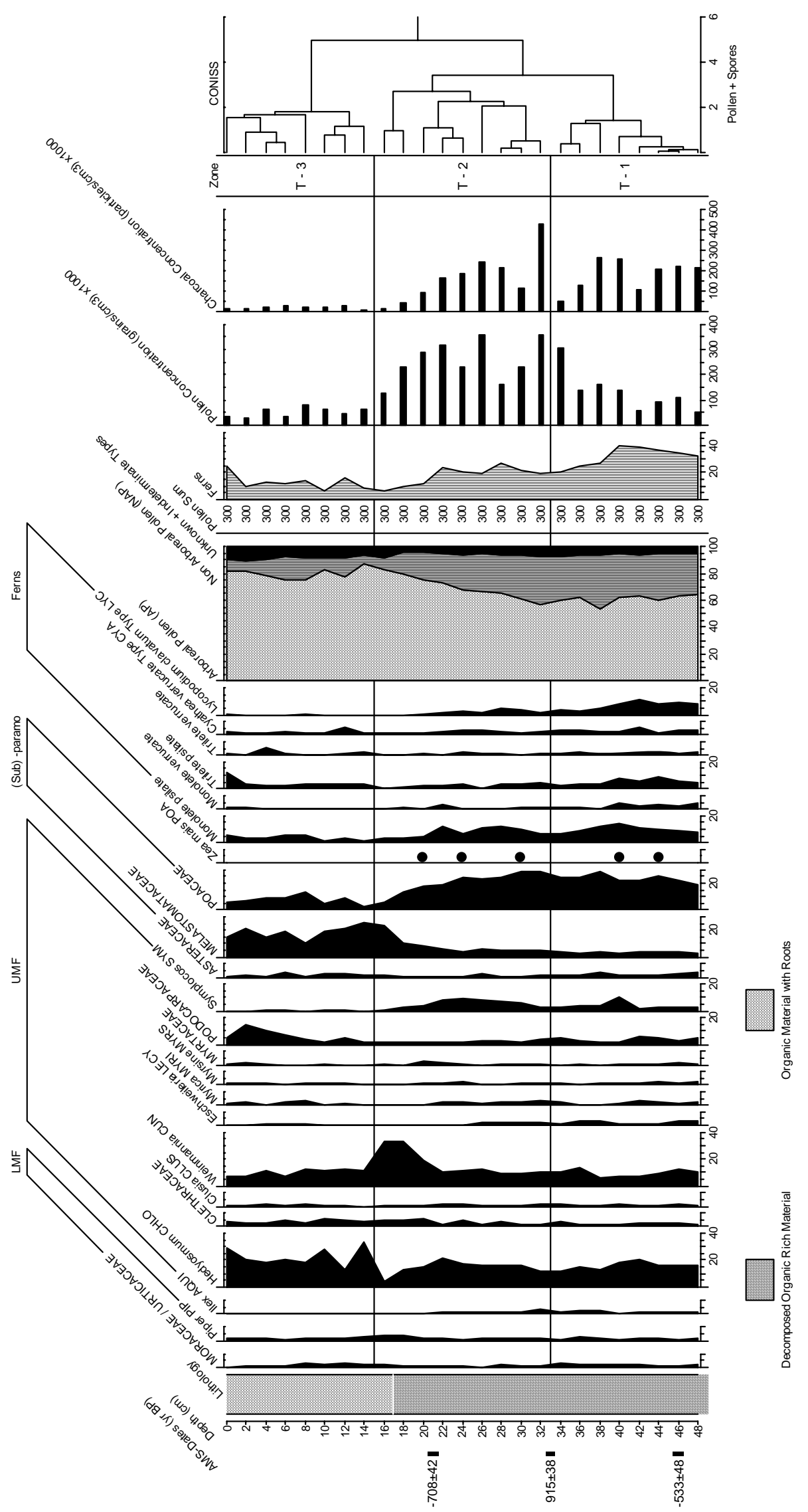

Figure 3.5: Pollen percentage diagram of the soil monolith from ECSF T2/250 (1990 m elevation) showing the AMS radiocarbon dates (yr BP), the lithology, selected pollen and spore taxa, grouped into lower mountain forest (LMF), upper mountain forest (UMF) and (sub)-paramo, sums of ecological groups, the pollen sum, pollen and charcoal concentration, the pollen zones and the CONISS dendrogram. 


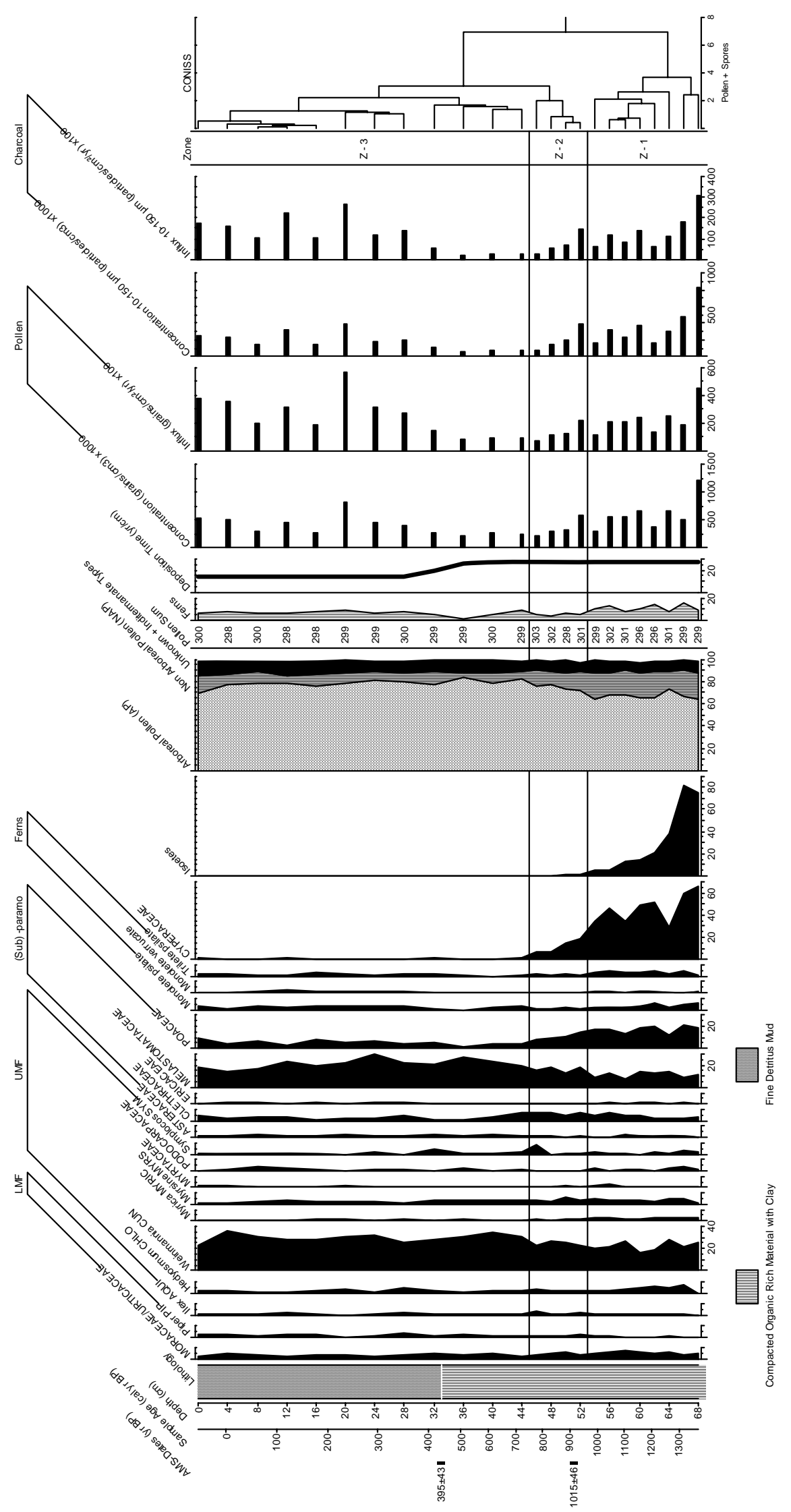

Figure 3.6: Pollen percentage diagram of the Laguna Laguna Zurita ( $2590 \mathrm{~m}$ elevation) sediment core showing the AMS radiocarbon dates, sample ages (cal yr BP), the lithology, selected pollen and spore taxa, grouped into lower mountain forest (LMF), upper mountain forest (UMF) and (sub)-paramo, sums of ecological groups, the pollen sum, the deposition time, pollen and charcoal concentration and influx, the pollen zones and the CONISS dendrogram. 


\section{Description of the pollen diagram of ECSF - T2/250 (Fig. 3.5)}

Zone T-1 (48-33 cm, older than 850 cal yr BP (1100 AD), 8 subsamples) is marked by a stable representation of AP and NAP. AP of Hedyosmum (10-15\%), Weinmannia (8-12\%), Symplocos, Podocarpaceae and Melastomataceae (all 5-10\%) are relatively frequent. NAP, especially Poaceae (20-25\%) is well represented. A single pollen grain of Zea mays is found in 2 samples. Monolete and trilete fern spores, especially the Lycopodium clavatum type (4$12 \%)$ are relatively frequent with a decreasing trend. Pollen concentration $(60,000-350,000$ grains $\left./ \mathrm{cm}^{3}\right)$ and charcoal concentration $\left(50,000-280,000\right.$ particles $\left./ \mathrm{cm}^{3}\right)$ is relatively high during this period.

Zone T-2 (33-15 cm, younger than $850 \mathrm{cal}$ yr BP (1100 AD), 9 subsamples) shows a strong increase of AP and a strong decrease of NAP. AP of Weinmannia (10-30\%), Hedyosmum (820\%), Melastomataceae (5-15\%), Symplocos (5-10\%), and Pudiaea (4-8\%) are relatively frequent. NAP, especially Poaceae (10-25\%) is well represented. A single pollen grain of Zea mays is found in 3 samples. Fern spores are relatively frequent. Pollen concentration $\left(200,000-380,000\right.$ grains $\left./ \mathrm{cm}^{3}\right)$ is highest and charcoal concentration $(20,000-450,000$ particles $\left./ \mathrm{cm}^{3}\right)$ is high with a strong decreasing trend.

Zone T-3 (15-0 cm, younger than 350 cal yr BP (1600 AD), 8 subsamples) is marked by a relatively stable representation of AP and NAP. AP of Weinmannia (18-35\%), Symplocos (4$11 \%)$ and Pudiaea (4-7\%) are relatively frequent. Melastomataceae (12-25\%), Hedyosmum (5-33\%) and Podocarpaceae (2-15\%) shows highest values during this period. Symplocos is absent now. NAP, especially Poaceae (4-14\%) shows lower values as the preceding zone. Fern spores are relatively rare during this period. Pollen concentration $\left(<100,000\right.$ grains $\left./ \mathrm{cm}^{3}\right)$ and charcoal concentration $\left(<20,000\right.$ particles $\left./ \mathrm{cm}^{3}\right)$ is lowest in this zone.

\section{Description of the pollen diagram of Laguna Zurita (Fig. 3.6)}

Zone Z-1 (68-53 cm, ca. 1400-970 cal yr BP, ca. 500-980 AD, 8 subsamples) is marked by a relatively stable representation of AP and NAP. AP of Weinmannia (18-27\%) and Melastomataceae (9-15\%) show high values during this period. Moraceae/Urticaceae (5-8\%), Hedyosmum (2-8\%), Clethra (2-7\%), Podocarpaceae, Symplocos, Myrica and Myrsine (all 1$5 \%)$ are well represented. NAP, especially Poaceae $(12-20 \%)$ show highest values in this zone. Cyperaceae (30-65\%) and spores of Isoetes show a strong decrease (from 3\% up to $82 \%$ ) in this zone. Fern spores are relatively rare and show no marked change in the record frequent. The values of pollen and charcoal (concentration and influx) run nearly similar in this record. Pollen concentration (0.4-1 million grains $\left./ \mathrm{cm}^{3}\right)$ and charcoal concentration $\left(200,000-800,000\right.$ particles $\left./ \mathrm{cm}^{3}\right)$, as well as pollen influx $\left(12,000-45,000\right.$ grains $\left./ \mathrm{cm}^{2} / \mathrm{yr}\right)$ and charcoal influx $\left(11,000-31,000\right.$ particles $\left./ \mathrm{cm}^{2} / \mathrm{yr}\right)$ decreases in this zone.

Zone Z-2 (53-45 cm, ca. 970-750 cal yr BP, ca. 980-1200 AD, 4 subsamples) shows an increase of AP and a decrease of NAP. AP of Weinmannia (22-30\%) and Melastomataceae (15-20\%) show high values during this period. Clethra (5-8\%), Moraceae/Urticaceae (3-6\%), Symplocos (1-9\%) and Myrsine (3-5\%) are well represented. NAP, especially Poaceae (7$15 \%$ ), with a decreasing trend, is well represented. Cyperaceae (5-30\%) show a strong decrease in this zone. Pollen concentration $\left(300,000-600,000\right.$ grains $\left./ \mathrm{cm}^{3}\right)$ and charcoal concentration $\left(100,000-500,000\right.$ particles $\left./ \mathrm{cm}^{3}\right)$, as well as pollen influx $(10,000-22,000$ grains $\left./ \mathrm{cm}^{2} / \mathrm{yr}\right)$ and charcoal influx $\left(5000-20,000\right.$ particles $\left./ \mathrm{cm}^{2} / \mathrm{yr}\right)$ decreases again in this zone.

Zone Z-3 (45-0 cm, ca. 750 cal yr BP (ca. 1200 AD) to present, 12 subsamples) is marked by a stable representation of AP and NAP. AP of Weinmannia (25-35\%) and Melastomataceae (15-30\%) shows highest values during this period. Clethra (1-7\%), Moraceae/Urticaceae (3-6\%), Piper, Hedyosmum, Podocarpaceae, Symplocos, and Myrsine 
(all ca. 0-5\%) are well represented. NAP, especially Poaceae (2-10\%) is represented. Pollen concentration $\left(200,000-700,000\right.$ grains $\left./ \mathrm{cm}^{3}\right)$ and charcoal concentration $(100,000-450,000$ particles $\left./ \mathrm{cm}^{3}\right)$, as well as pollen influx $\left(9000-58,000\right.$ grains $\left./ \mathrm{cm}^{2} / \mathrm{yr}\right)$ and charcoal influx (4000-27,000 particles $/ \mathrm{cm}^{2} / \mathrm{yr}$ ) show high amounts during this period.

\section{XRF- scanning and physical properties of the Laguna Zurita sediment core (Fig. 3.7)}

The zonation of the pollen diagram (Z-1, Z-2, and Z-3) was also used for XRF data. A correlation matrix (Spearman Rank Order Correlation) showed positive correlations of Ti to $\mathrm{K}, \mathrm{Fe}$ and $\mathrm{Si}(\mathrm{K}: \mathrm{r}=0.715$, Fe: $\mathrm{r}=0,629$ and $\mathrm{Si}: \mathrm{r}=0.837, \mathrm{~K}$ to $\mathrm{Fe}: \mathrm{r}=0,800$ and $\mathrm{Si}: \mathrm{r}=0,921$ and Fe to $\mathrm{Si}: \mathrm{r}=0.753, \mathrm{p}<0.001$ ). Al was also correlated significantly to all four elements ( $\mathrm{Si}$ : $\mathrm{r}=0.476, \mathrm{Fe}: \mathrm{r}=0.519, \mathrm{~K}: \mathrm{r}=0.558$, Ti: $\mathrm{r}=0.452, \mathrm{p}>0.001$ ). As correlations among the mentioned elements are significant and show high correlation coefficients only $\mathrm{Si}$, $\mathrm{Ti}$ and $\mathrm{Fe}$ are plotted for palaeoenvironmental reconstruction. All other elements showed too low counts for interpretation.

In zone Z-1 Si, Ti and Fe counts reach highest amounts with a strong decrease. In Zone Z-2 and Z-3 Si, Ti and Fe counts show relative low amounts, with a minimum between 46 and 34 $\mathrm{cm}$. Magnetic susceptibility $(\kappa)$ was correlated positive to $\mathrm{Si}: \mathrm{r}=0.638, \mathrm{Fe}: \mathrm{r}=0.535, \mathrm{~K}$ : $\mathrm{r}=0.567$, Ti: $\mathrm{r}=0.714$ and $\mathrm{Al}: \mathrm{r}=0.458, \mathrm{p}>0.001$ and broadly follows the records of $\mathrm{Si}, \mathrm{Ti}$ and Fe.

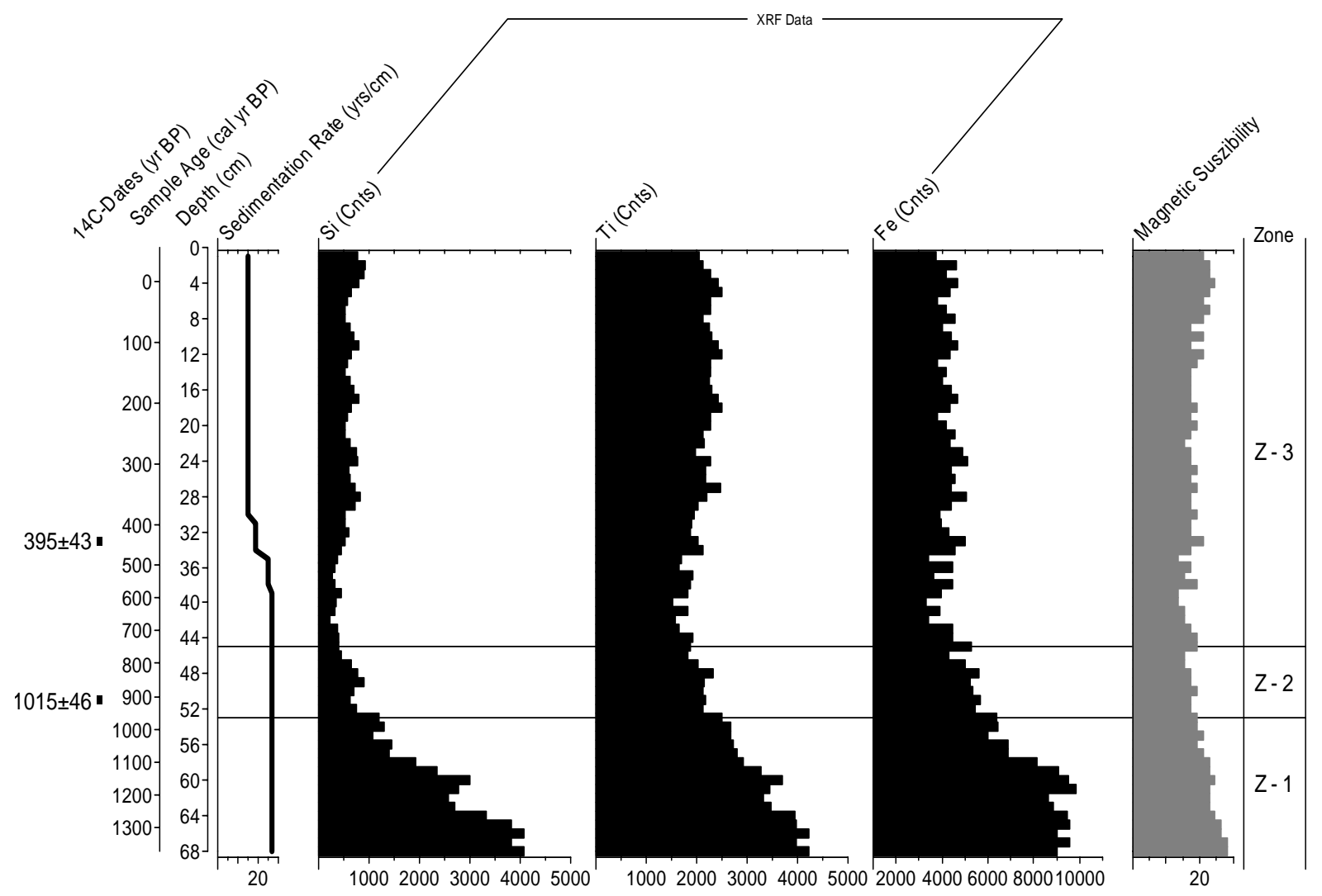

Figure 3.7: Diagram of physical properties showing the AMS radiocarbon dates, sample ages (cal yr BP), the sedimentation rate, XRF-data and magnetic susceptibility and the pollen zones of Laguna Zurita sediment core. 


\subsection{Interpretation and discussion}

\section{Vegetation, climate and fire dynamics}

The pollen record of ECSF Cerro de Consuelo at $3155 \mathrm{~m}$ elevation (Fig. 3.3) in general shows no marked changes except the higher occurrence of Podocarpaceae, Hedyosmum, Ilex, Myrsine and Ericaceae in zone C-1 before ca. 1200 cal yr BP (ca. 750 AD). In zone C-2 between ca. 1200-920 cal yr BP (ca. 750-1030 AD) the charcoal influx and concentration is markedly higher than in the lower and upper core part. The decrease of Podocarpaceae, Hedyosmum, Ilex, Myrsine and Ericaceae after the increase of the fire frequency may suggest a shift of the tree line into lower elevations. Fires were probably initiated by humans (e.g. uncontrolled burning), rather than natural fires (see also below). The reason for the low tree line in Podocarpus National Park area is still in discussion. It might be a result of the so-called Andean depression which probably causes a shift of the tree line into lower elevation. Pollen analysis from Pantano de Pecho $(3870 \mathrm{~m})$ in the central Ecuadorian paramo documents altitudinal migrations of the upper forest line prior to deforestation. The upper forest line moved upslope from a minimum between 3400 to $3500 \mathrm{~m}$ during the period from ca. 1290 to $1315 \mathrm{AD}$, to the highest level of $3750 \mathrm{~m}$ (ca. 1640-1765 AD) (Wille et al. 2002). At the El Tiro-Pass, $10 \mathrm{~km}$ west of (ECSF) research area, the modern tree line is at ca. $2800 \mathrm{~m}$; this is about 600-800 $\mathrm{m}$ lower, than in central and northern Ecuador (Bader 2007).

The modern (sub)-paramo vegetation developed in zone C-3 after ca. 920 cal yr BP (ca.1030 AD). A decrease of Weinmannia as well as a low fire frequency and an increase of Melastomataceae, Poaceae and Jamesonia may indicate less human activity rather than cooler conditions at higher elevation.

The pollen record of ECSF Refugio at 2520 m elevation (Fig. 3.4) shows a change of the floristic composition, a decease of Podocarpaceae, Ilex, Myrtaceae and ferns as well as a strong increase of Melastomataceae in zone R-2 at ca. 800 cal yr BP (ca. 1150 AD. Apparently the decrease of fire frequency in zone R-2 is responsible for the change in vegetation composition. The local extinction of the tree fern, probably Cyathea conjugate, might be also related to the frequent burning during the past. The modern upper mountain forest vegetation becomes established in zone R-3 after ca. 800 cal yr BP (ca. 1150 AD).

The relatively frequent pollen of Clethraceae in the UMF zone probably originates almost from the tree Purdiaea nutans. Clethra itself is rare in the ECSF research area. Purdiaea nutans is a rare tree in the northern Andes, but exceptional frequent in the ECSF research area between $2150 \mathrm{~m}$ and $2650 \mathrm{~m}$ elevation. The Purdiaea forest, with amounts up to about $80 \%$ of the individuals, is poor in other species (Mandl et al. 2008). A separation of Clethra- and Purdiaea pollen in fossil archives is not possible. The pollen record of ECSF Refugio shows the lowest pollen and spore; only 72 different taxa have been identified (Tab. 3.1). The low diversity might be a result of the dominance of Purdiaea.

The pollen record of ECSF T2/250 at 1990 m elevation (Fig. 3.5) shows a marked change of the floristic composition at ca. $400 \mathrm{cal}$ yr BP, 1550 AD (extrapolated). Weinmannia, Melastomataceae and Hedyosmum increase, Poaceae and ferns decrease. Apparently the strong decrease of fire is responsible for this vegetation change, indicating forest recover of open areas on the slopes. The very high number of Poaceae and few Zea mays pollen grains, coupled with the high frequency of fires (evidence of macroscopic charcoal in the sediments) indicates burning activity near the study site before the change of the floristic composition occurred. The lower distribution of Poaceae and the missing of Zea mays, coupled with the very low frequency of fires, indicate the absence of human activity near the core site in the ECSF area in zone T-3 after ca. 400 cal yr BP, 1550 AD (extrapolated). The modern vegetation with a high number of Weinmannia, Melastomataceae, Hedyosmum and Podocarpaceae becomes established in zone T-3 after ca. 400 cal yr BP, 1550 AD 
(extrapolated), reflecting a successional forest recovery. The pollen diagram from El TiroPass $(2810 \mathrm{~m})$, about $10 \mathrm{~km}$ from ECSF research area shows also a strong decrease of fire intensity during the last centuries (Niemann and Behling 2008c).

The pollen record of Laguna Zurita at 2590 m elevation (Fig. 3.6) shows a high occurrence of Poaceae and a lower occurrence of Weinmannia, Melastomataceae and Clethra, coupled with relative high fire intensity, reflecting a somewhat open forest around the lake in zone Z-1 before ca. 970 cal yr BP (ca. 980 AD). The high occurrence of Cyperaceae and Isoetes indicates marshy lake shores with a low lake level. The strong decrease of Isoetes, reflects a lake level rise during this period. The high values of $\mathrm{Fe}, \mathrm{Ti}$ and $\mathrm{Si}$ are representing sedimentary input of the bedrock (Fig. 3.7). The decrease of Isoetes in zone Z-1, may be reflect a higher precipitation before ca. 790 cal BP (ca. 1160 AD), associated with a lake level increase at Laguna Zurita core site. The Fe, Ti and Si record can be interpreted as an indicator for fluvial terrigenuous sediment influx, magnetic susceptibility $(\kappa)$ can be used as indicator for detrital input (e.g., Lamy et al. 2001, 2004; Richter et al. 2006). Environmental records from other sites in the northern Andes indicate an increase of wetter conditions. For example from three old river channel lakes (Rio Napo) in the western Amazon basin of Ecuador show regional flooding from ca. 700-1200 AD (Colinvaux et al. 1988a). Pollen data from the endorheic Lake Ayauch in the Inter-Andean Plateau of Ecuador reveal local evidence for a moist episode from ca. 400 to $1200 \mathrm{AD}$ and a moist climate in the Inter-Andean Plateau (Colinvaux et al. 1988b). Palaeolimnological records from Lake Titicaca (Bolivia) show a wet period from ca. $1500 \mathrm{BC}$ to $1100 \mathrm{AD}$ (Binford et al. 1997).

Zone Z-2 shows a marked change of the floristic composition between ca. 970 and $750 \mathrm{cal}$ yr BP (ca. 980-1200 AD). Poaceae decrease, Weinmannia and Melastomataceae increases, indicating a change from a somewhat open to a closed forest around the lake. The decrease of Cyperaceae coupled with a very low occurrence of Isoetes reflects a lake level rise and a decrease of marshy lake shores during this period. The low occurrence of Cyperaceae and the missing of Isoetes indicate a lake level closed to modern times in zone Z-3 after ca. $750 \mathrm{cal} \mathrm{yr}$ BP (ca. 1200 AD). Lower values of Fe, Ti and Si between ca. 790 and 480 cal yr BP (ca. 1160-1470 AD) (Fig. 3.7) indicates decreasing sedimentation rates, may be reflecting drier climatic conditions. Otherwise, the establishment of closed vegetation, caused by less human activities around the lake as well as the decreasing lake shores are responsible for the lower sedimentation rates. Higher values of $\mathrm{Fe}$, Ti and Si after 480 cal yr BP indicates increasing sedimentation rates, may be reflecting wetter climatic conditions. The records of charcoal concentration and influx do not correspond to the dry/wet cycles, may be indicating that fires caused by human activities (low between ca. 790 and $480 \mathrm{cal}$ yr BP and decreasing after 480 cal yr BP). A palaeoclimatic record from the Cuzco region in Peru shows a longer dry episode occurring from ca. 900 to 1800 AD (Chepstow-Lusty et al. 2003). During the late Holocene, stable isotopes in ice cores from Huascaran in the central Peruvian Andes (up to $6000 \mathrm{~m}$ elevation), indicate a warmer period from ca. 1140 to $1250 \mathrm{AD}$, possibly reflecting the "Medieval Warm Period" and a cooler period between ca. 1300 and 1850 AD, correlating with the "Little Ice Age" period of the northern hemisphere (Thompson et al. 2003). Palaeolimnological records from Lake Titicaca (Bolivia) show a dry period between ca. 1100 and $1400 \mathrm{AD}$ (Binford et al. 1997).

Our data, as well as excavation near the lake shore during the field work could not answer the question, if the lake is natural or not? A landslide or human activities could be responsible for the establishment of the lake. Human caused, as well as natural landslides on phylitic bedrock are often observed in the region. A human made water reservoir for agricultural use appears useless, due to the high precipitation rates in the upper Rio San Francisco valley. After Guffroy (personal communication) the pre-Inca Palta culture practices simple agricultural methods, probably not dam up lakes. 


\section{Human impact}

The pollen records from ECSF T2/250, ECSF Refugio and Laguna Zurita in general shows a floristic change between ca. 970 to 400 (extrapolated) cal yr BP (ca. 980-(1550) AD). Arboreal pollen increases and non arboreal pollen (especially Poaceae) and ferns decrease. This is coupled with a decrease of fire intensity (ECSF T2/250 and ECSF Refugio), indicating a reduction of human activities. The reduction of human activities may be a result of civil conflicts in pre Inca time, the resettling politics of the Inca and the arrival of the Spanish conquest. After the reduction and/or absence of human influence the forest starts to recover in the upper Rio San Francisco valley from between ca. 970 to 400 (extrapolated) cal yr BP (ca. 980-(1550) AD). During the field work a high number of terraces have been observed in the Rio San Francisco valley, as well as in the whole Loja region. In the ECSF research area these terraces, located closed to the valley bottom, were overgrown. The high number of terraces indicates human activities during the past. Dated terraces in the Loja region show pre-Inca and Inca age (Guffroy, personal communication). First human activity in the region of Loja has been dated by around $4000 \mathrm{yr}$ BP (Guffroy 2004). In the $8^{\text {th }}$ century, indigenous population came in war in the La Toma valley, about $10 \mathrm{~km}$ north of Loja (Guffroy 2006). In the middle of the $15^{\text {th }}$ century the Inca occupied Ecuador. They defeat the indigene chiefdom called Palta. It was the strategy of the Inca to settle defeated populations in other regions of their empire and this has happened with the Palta (Alvaredo 2002). The Saraguros, settling northeast of Loja, are highland Indians originally came from the Titicaca region in Bolivia and were resettled as workers and vassals in the Andean highlands by the Incas (Pohle 2008). After the almost 70-year rule (1463-1531 A.D) in southern Ecuador the Inca were defeated by the Spanish conquests (Pohle 2008). The Spanish occupants brought old world diseases to the new world, including Ecuador, causing a decrease of the indigenous population (Alchon 1991). During the mid of $17^{\text {th }}$ century the Spanish conquests lost the control over the region between Loja and Zamora in fights with the indigenous population.

The occurrence of Zea mays shown in the pollen records of ECSF T2/250 before ca. $400 \mathrm{cal}$ yr BP, ca. 1550 AD (extrapolated) and ECSF Refugio at ca. 800 cal yr BP (ca. 1150 AD), reflects human activity. The most pollen of Zea mays are found in lower altitudes (ECSF $\mathrm{T} 2 / 250$ ), indicating that the cultivating of Zea mays has happened at the lower part of the slopes (were overgrown terraces have been observed), closed to the modern and probably past way system. The extrapolated age (ca. 400 cal yr BP, 1550 AD) shows that the floristic change has happened latest at the study site of ECSF T2/250, may be reflecting an earlier reduction and/or absence of human activities at the slopes in higher elevation. Results from Ecuadorian Amazonia and Colombia also show a reduction of human activity during the late Holocene. After ca. 2340 cal yr BP grassy vegetation remains abundant in the Colombian Cauca Valley. Presence of crop taxa (e.g. Zea mays) and an increase in charcoal point to the presence of pre-Columbian people. After ca. $870 \mathrm{cal} \mathrm{yr} \mathrm{BP,} \mathrm{expansion} \mathrm{of} \mathrm{secondary} \mathrm{forest}$ taxa may indicate depopulation and abandonment of previously cultivated land. After ca. 490 cal yr BP, possibly related to the Spanish conquest, secondary forest expanded and charcoal concentrations increased, possibly indicating further reduction of cultivated land (Berrio et al. 2002). The pollen record from Lake Ayauch $(500 \mathrm{~m})$, southeastern part of Ecuadorian Amazonia shows Zea cultivation between ca. 2960 and ca. $720 \mathrm{cal}$ yr BP. The abandonment of Zea cultivation may have been due social unrest (Bush and Colinvaux 1988).

The installation of the road between Loja and Zamora, as well as the power station next to the ECSF research area in the late 1950s is responsible for new settlements including landscape disturbance during the last decades. The decrease of arboreal pollen during the last ca. 50 years, shown in the records Laguna Zurita and ECSF Refugio, indicates this. At modern times the ECSF research area is a closed forest system surrounded of disturbed 
landscape. The resettling started in the mid of $20^{\text {th }}$ century by Mestizes Colonos, settlers from other parts of Ecuador (Pohle 2008).

\subsection{Conclusions}

In order to study the stability of mountain rainforest ecosystems, the role of fires and the human impact during the past, four AMS radiocarbon dated records from different elevations of the upper Rio San Francisco valley have been investigated by pollen, spore and charcoal analysis. Our palaeoenvironmental studies indicate that fires have markedly influenced the stability of the floristic composition of the mountain rainforest ecosystem of the upper Rio San Francisco valley, including the ECSF research area. The forest ecosystem was instable during the late Holocene because of frequent fires before ca. 970 to 400 (extrapolated) cal yr BP. Fires were apparently of anthropogenic origin. High occurrence of grasses and some corn plantations, document past human activities in the Rio San Francisco valley. After the decrease of fires ca. 970 to 400 (extrapolated) cal yr BP, cohered with the reduction and/or absence of human influence, open areas starts to recover by forests in the upper Rio San Francisco valley. A succession of Weinmannia and Melastomataceae first reacts on decreasing fires, reflecting the high sensitivity of these taxa. The reduction and/or absence of human activities may be a result of political unrest (civil conflicts in pre Inca time, the resettling politics of the Inca and the arrival of the Spanish conquest).

However, the mountain rainforest of the ECSF research area is not virgin, due to the marked human impact during the past, but otherwise, more than for centuries without marked disturbances can be characterised as a relatively "natural" stage of a mountain rainforest ecosystem.

Acknowledgements: Felix Matt (research station leader) is thanked for his logistical support and for his information about the study region. Thanks to Ursula Röhl (MARUM, University of Bremen) for using the XRF-scanner, Thorsten Friedrich (Geosciences, University of Bremen) for using the MS-scanner and to Torsten Haberzettl (Geoscience Centre, University of Göttingen) for using the software to plot physical properties. The project FOR 402/D1 (Vegetation-, climate- and fire dynamics in the Podocarpus National Park region) is kindly funded by the Deutsche Forschungsgemeinschaft (DFG). 


\title{
4. Holocene vegetation, climate and fire dynamics inferred from the $(11,700$ cal yr BP) Laguna Rabadilla de Vaca multi-proxy record in the southeastern Ecuadorian Andes
}

The Holocene (in review)

Holger Niemann ${ }^{1}$, Torsten Haberzettl ${ }^{2}$, Hermann Behling ${ }^{1}$

${ }^{1}$ Department of Palynology and Climate Dynamics, Albrecht-von-Haller-Institute for Plant Sciences, University of Göttingen, Untere Karspüle 2, 37073 Göttingen, Germany

${ }^{2}$ Sedimentology and Environmental Geology, Geoscience Centre, University of Göttingen, Goldschmidtstr. 3, 37077 Göttingen, Germany

\begin{abstract}
In order to study stability and dynamics of mountain rainforest and paramo ecosystems, the Holocene climate and fire variability and human impact in the southeastern Ecuadorian Andes we present a high resolution multi-proxy record from Laguna Rabadilla de Vaca (3312 m elevation), Podocarpus National park, Ecuador.

Palaeoenvironmental changes, inferred from a $492 \mathrm{~cm}$ long lake sediment core, spanning the last ca. 11,700 cal yr BP, were investigated by pollen, spores and charcoal analyses, in combination with XRF- and magnetic susceptibility-scanning. Pollen data indicate that herbparamo was the main vegetation type at Laguna Rabadilla de Vaca during the early Holocene period, before ca. 8990 cal yr BP. The herb-paramo was rich in Poaceae, Cyperaceae, Valeriana, and Huperzia reflecting cold and relatively wet climatic conditions. During the mid Holocene at ca. 8990-3680 cal yr BP Weinmannia increases markedly, indicating warmer climatic conditions due to a spread of a shrub-paramo vegetation and/or a shift of mountain rainforest and subparamo vegetation zones into higher elevation. XRF data indicates a drier period at ca. 8990-6380 cal yr BP and a wetter period at ca. 6380-3680 cal yr BP. A Poaceae dominated herb-paramo occurred from ca. 3680 cal yr BP until modern times, reflecting cooler climatic conditions relative to the mid Holocene period. XRF- and charcoal data indicates a decrease in precipitation after ca. $3680 \mathrm{cal}$ yr BP.
\end{abstract}

Keywords: Ecuador, paramo, pollen analysis, fire history, climate change, XRF-scanning, human impact, Weinmannia 


\subsection{Introduction}

The Ecuadorian Andes harbour the most species rich ecosystems on earth (Barthlott et al. 2005). The Ecuadorian ecosystems have been strongly affected during the last decades. Natural vegetation regeneration and sustainable management is urgently needed as well as conservation of natural areas. To carry out this task, basic knowledge of ecosystem development and dynamics, the effect of climate change on ecosystems and its reaction, the role of fire, and as well as human impact during the past, is required.

A few a palaeoenvironmental records are available from southern Ecuador and neighbouring regions, all locations, cited in the following text, are shown in figure 4.1.

The pollen record from El Tiro-Pass $(2718 \mathrm{~m})$, southeastern Ecuadorian Andes, shows an expansion of subparamo and upper mountain rainforest vegetation during the early Holocene (ca. 11,200-8900 cal yr BP) which indicates a slow warming of climatic conditions. From ca. 8900-3300 cal yr BP an upper mountain rainforest developed at the study site, indicated by an increase of Hedyosmun, Podocarpaceae, Myrsine and Ilex, suggesting a warmer climate than present-day at this elevation. The modern subparamo vegetation became established since ca. 3300 cal yr BP (Niemann and Behling 2008c).

At Laguna Chochos (3285 m), eastern Peruvian Andes, a warm and wet early Holocene was interrupted by a warm-dry event (ca. 9500-7300 cal yr BP). Deglaciation was locally complete at ca. 11,700 cal yr BP (Bush et al. 2005).

Pollen-, charcoal- and radiocarbon data from Colombian inter Andean Cauca Valley (1020 $\mathrm{m})$, indicates dry climatic conditions relative to the present from ca. 9670-3030 cal yr BP, with a maximum at ca. $8300 \mathrm{cal}$ yr BP, when the dry forest reached maximum expansion (Berrio et al. 2002).

Ice cores from Huascaran (ca. $6050 \mathrm{~m}$ ), central Peruvian Andes indicate that climate was warmest from ca. 9455-5960 cal yr BP (Thompson et al. 1995).

Diatomites from lacustrine deposits, exposed around Lake Aricota at $2800 \mathrm{~m}$, central Peruvian Andes, associated with highstands several meters above the modern lake level indicate wet episodes. Maximum Holocene lake level was attained before ca. 7000 cal yr BP and ended ca. $2800 \mathrm{cal}$ yr BP. Moderately high lake levels occurred at ca. 1600 and ca. 1230 cal yr BP. The highstand at Lake Aricota during the mid Holocene is coeval with a major lowstand at Lake Titicaca (Placzek and Quade 2001).

At Lake Titicaca (3810 m), central Peruvian Andes, a dry event from ca. 9000-3100 cal yr $\mathrm{BP}$ is inferred from changes in the vegetation composition by fossil pollen and charcoal analyses (Paduano et al. 2003).

Seismic reflection data were collected to investigate the late Quaternary stratigraphic development of Lake Titicaca. An erosion surface is interpreted to be coeval with a welldocumented early- to mid-Holocene lowstand, dated between ca. 8000-3600 cal yr BP (D'Agostino et al. 2002).

The pollen record Yasuni National Park $(220 \mathrm{~m})$, Ecuadorian Amazonia, shows a longlasting frequency of Cecropia pollen (ca. $8700-5800 \mathrm{cal} \mathrm{yr} \mathrm{BP}$ ) is tentatively interpreted as a period of increased tree mortality, indicating a drought-prone period. The climatic conditions from ca. 5800-4900 cal yr BP and ca. 3700-1000 cal yr BP were relatively wet. From ca. 4900-3700 cal yr BP and from ca. 1000 cal yr BP to present they have been relatively dry (Weng et al. 2002).

The pollen record from Laguna Loma Linda $(310 \mathrm{~m})$, located in the transition zone between the savanna of the Llanos Orientales and the Amazon rainforest in Colombia, indicate a significantly lower and seasonality stronger precipitation than today during the period from ca. 9650-6850 cal yr BP. From ca. 6850-3900 cal yr BP, rainforest taxa increased markedly, reflecting an increase in precipitation. From 3900 to 2300 cal yr BP rainforest taxa continued to increase, precipitation was still increasing, and the length of the annual dry period possibly 
shortened. From 2300 cal yr BP onwards, grass savannah expanded reflecting increased human impact on the vegetation (Behling and Hooghiemstra 2000).

In this paper, we discuss vegetation, climate and fire dynamics inferred from a fossil pollen and charcoal record in combination with XRF- and magnetic susceptibility-scanning data from Laguna Rabadilla de Vaca (Podocarpus National park, southeastern Ecuadorian Andes) with a special focus on the climatic conditions during the past and the development of different mountain rainforest and paramo ecosystem types. Only few proxy data is available for the tropical South America. This study has been carried out in the framework of the "Deutsche Forschungsgemeinschaft" (DFG) research group "Tropical Mountain Ecosystems".

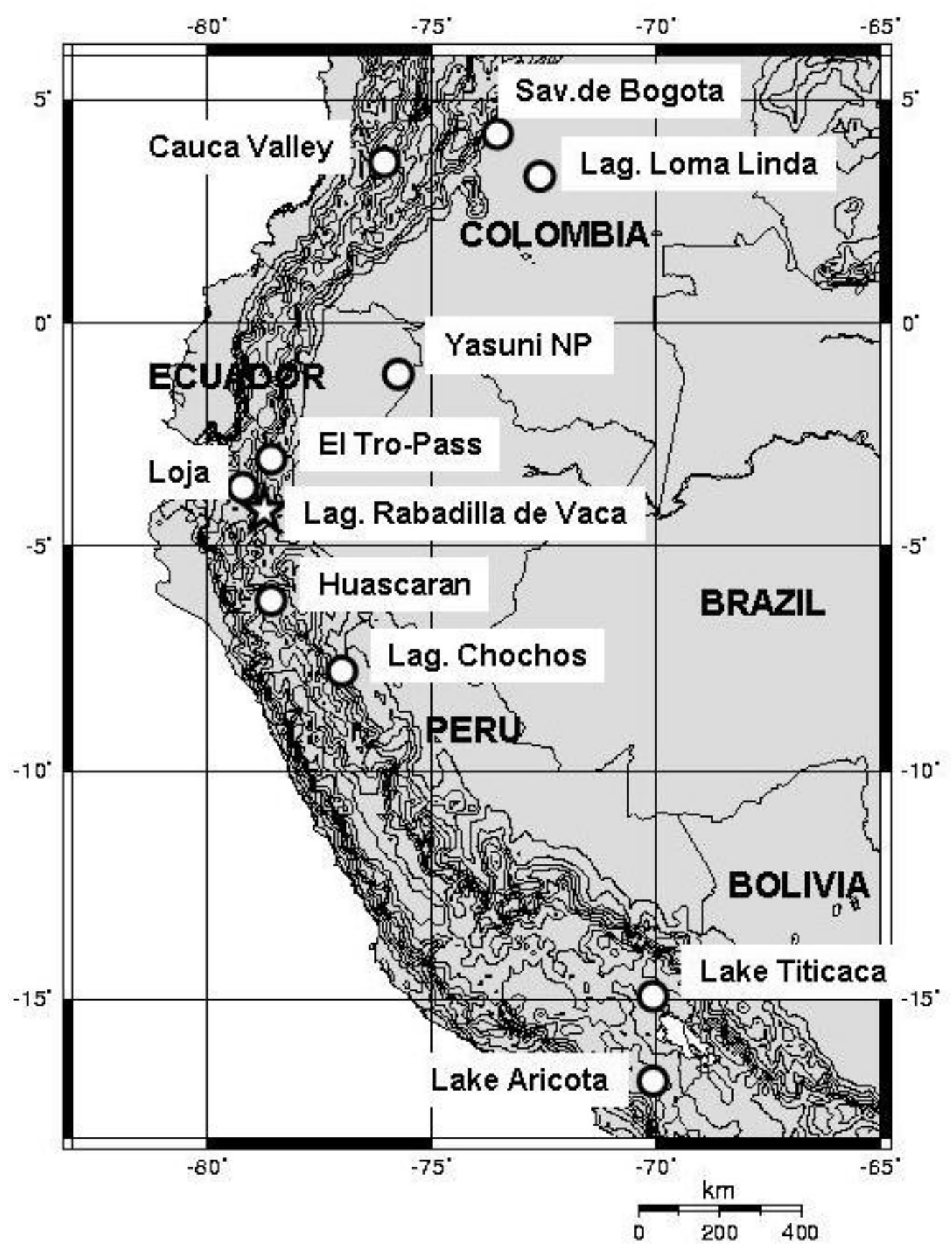

Figure 4.1: Map of central northwestern tropical South America, showing Laguna Rabadilla de Vaca (star) and other locations discussed in the text (circles). The map was created under using OMC (www.aquarius.geomar.de). 


\subsection{Site description}

\section{Location}

Laguna Rabadilla de Vaca $\left(04^{\circ} 15^{\prime} 19.7^{\prime \prime} \mathrm{S}, 079^{\circ} 06^{\prime} 43.7^{\prime \prime} \mathrm{W}\right)$, at $3312 \mathrm{~m}$ elevation is located at the western slope of the eastern Cordillera (Cordillera Real) in the southeastern Ecuadorian Andes (Fig. 4.1), about $10 \mathrm{~km}$ east of the small village of Vilcabamba $(1700 \mathrm{~m})$ and about 15 $\mathrm{km}$ south of Cajanuma (Podocarpus National park entrance). Laguna Rabadilla de Vaca is part of the so called Lagunas de Compadre, about 15 lakes formed by glaciers, located east and west of the eastern Cordillera in the middle of the Podocarpus National park.

\section{Geomorphology and Geology}

The Andes are a mountain chain, with peaks up to an altitude of more than $6000 \mathrm{~m}$. The Andes of southern Ecuador and northern Peru include the so-called Andean depression (Depression de Giron-Cuenca in Ecuador and Huancabamba in Peru). The main peaks of the mountains in this region only reach up to about $4000 \mathrm{~m}$. Active volcanoes are absent (Richter and Moreira-Munoz 2005).

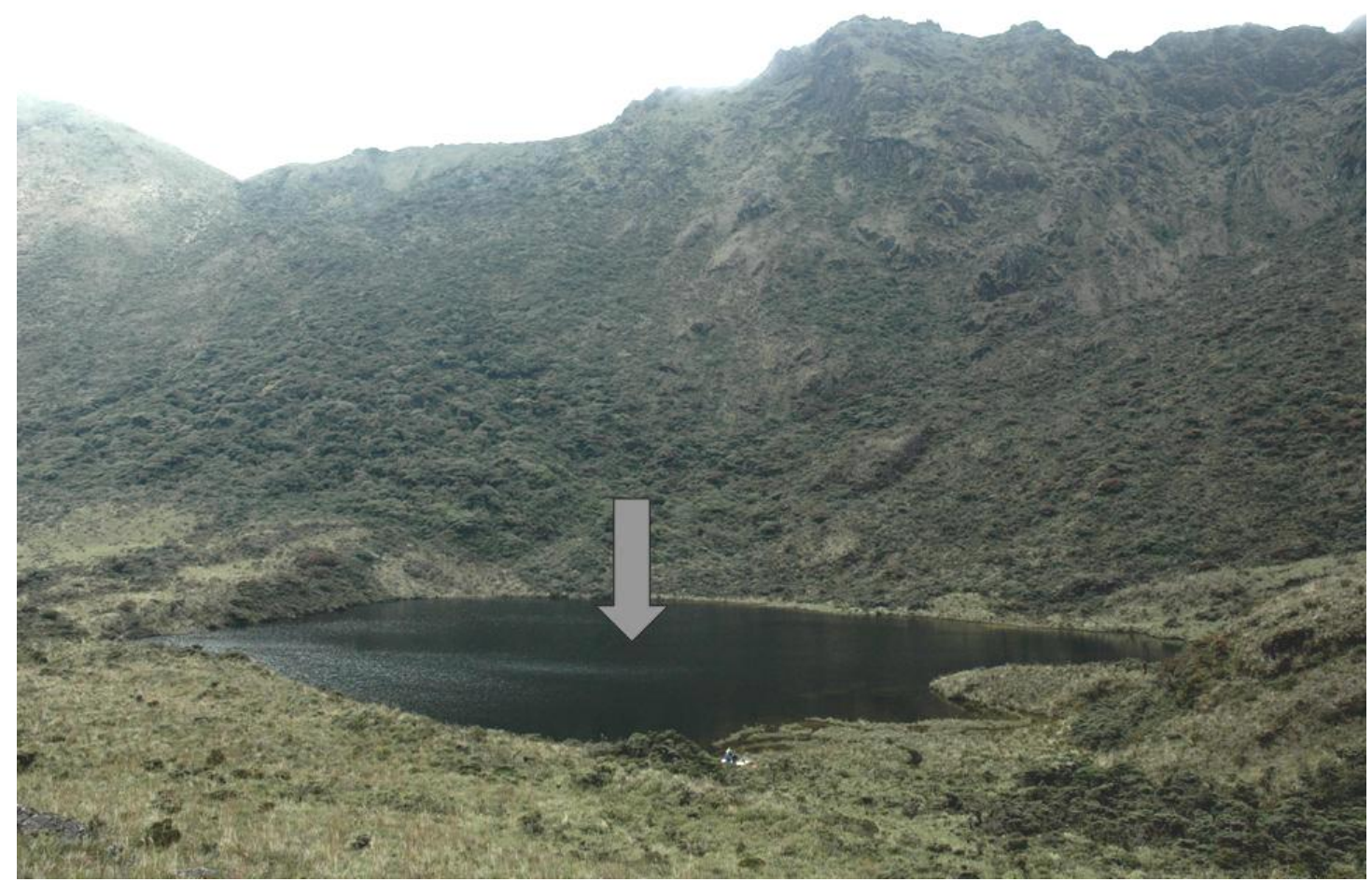

Figure 4.2: Photograph (from southwest) of Laguna Rabadilla de Vaca, with the east Andean divide in the background. The slopes are covered with shrub paramo vegetation and the lake shore covered with herb-paramo vegetation. The core section is marked with an arrow.

Laguna Rabadilla de Vaca (Fig. 4.2) is located very close to the eastern Andean divide at the base of a cliff created by a large valley glacier originating on higher elevations of the divide. The slope behind the lake reaches up to $3600-3700 \mathrm{~m}$. To its west the lake is dammed by a recessional moraine. The depth in the centre of the lake is about 5-8 $\mathrm{m}$ and the surface area is about 6 ha. The catchment is about $1.5-2 \mathrm{~km}^{2}$, the outflow of the lake is on its western part. 
The southern Cordillera Real is mainly built up by the "Zamora series", consisting of Palaeozoic metamorphic rocks of widely varying metamorphic grade. Local bedrock is dominated by semipelites, quartzites and black phylites with some granitic intrusions (Litherland et al. 1994).

\section{Modern vegetation}

Laguna Rabadilla de Vaca is located in the paramo vegetation zone. Two different types of modern paramo ecosystems are estimated for the Podocarpus National park region.

The herb-paramo (Paramos herbaceos), located at ca. 3200-3400 m, is rich in Neurolepis nana, Calamagrostis macrophylla (Poaceae) and Niphogeton dissecta (Apiaceae). The herbs and shrubs grow up from $0.2 \mathrm{~m}$ to $1 \mathrm{~m}$ height. This paramo type was found at flat slopes and concave sections as well as in ridge areas (Lozano et al. 2003) and occurs around Laguna Rabadilla de Vaca.

The shrub paramo (Paramos arbustivos bajos), located at ca. 2900-3400 m, is rich in Weinmannia rollottii (Cunoniaceae), Oxalis spiralis (Oxaliaceae) and Ilex andicola (Aquifoliaceae). The shrubs and herbs grow up from $0.5 \mathrm{~m}$ to $1.2 \mathrm{~m}$ height. This paramo type was found mainly at steep slopes (Lozano et al. 2003). The slopes above Laguna Rabadilla de Vaca are covered with this paramo type.

At lower elevation between ca. 2800-3100 m, subparamo is present, characterised by Puya nitida (Bromeliaceae), Brachyotum rotundifolium (Melastomataceae) and Oritrophium peruvianum (Asteraceae). The shrubs and herbs grow up to $1 \mathrm{~m}$ height, individual shrub species can be 2-3 m tall (Lozano et al. 2003).

The two different mountain rainforest ecosystems are descript for the Podocarpus National park region. The upper mountain rainforest is present between ca. $2100-2850 \mathrm{~m}$, replaced by a low, monotypic formation, with only one tree stratum between 5-10 m, rarely up to $15 \mathrm{~m}$. Characteristic trees are Purdiaea nutans (Cyrillaceae), Myrica pubescens (Myricaceae) and Myrsine andina (Myrsinaceae). The lower mountain rainforest is present between ca. 1800$2150 \mathrm{~m}$ with an extremely diverse, two-storied tree stratum and is composed of numerous 20$35 \mathrm{~m}$ tall tree species. Characteristic species are e.g., Alzetea verticillata (Alzataceae), Graffenrieda miconioides (Melastomataceae) and Myrcianthes sp. (Myrtaceae) (Bussmann 2001, 2005; Lozano et al. 2003).

The modern tree line in northern and central Ecuador is at about 3400-3600 m. At the El Tiro-Pass, $30 \mathrm{~km}$ north of the core site, the modern tree line is at ca. $2800 \mathrm{~m}$, this is about 600-800 m lower. A shift of vegetation zones into lower elevation is probably a result of the so-called Andean depression (Bader 2007).

\section{Climate}

The climate in the southeastern Ecuadorian Andes is influenced by warm moisture-laden air from the Amazon lowland, which collides with cold mountain air masses. This produces much of the rainfall in the eastern Andean mountains. The climate of the paramo is the humid tropical diurnal type with cold nights and cool days. There is a drier period lasting from December until March (Bosman et al. 1994). As part of the so-called Andean depression, all summits in the southern Ecuadorian Andes are below the snowline.

The eastern Andean mountains form a division that separates the moist eastern slopes of the Andes from the dry inner-Andean basins (e.g., the Loja- and Catamayo Basin). Between the eastern slopes of the eastern Cordillera and the dry valley of Catamayo, which are only $70 \mathrm{~km}$ apart, annual rainfall rates drop from over $4000 \mathrm{~mm}$ to $300 \mathrm{~mm}$ (Bendix et al. 2004).

Laguna Rabadilla de Vaca is located close to the eastern Andean divide and highly influenced by easterly trade winds (average annual speed $9.3 \mathrm{~m} / \mathrm{s}$ ) from the Amazon lowland. 
In the winter months (June-August), this trade wind system is very strong and stable, in the summer months (November-March) it is sometimes interrupted by westerly winds for a few days. The annual precipitation rate at Cajanuma, western slope, ridge exposed $(3400 \mathrm{~m})$ is about $5700 \mathrm{~mm}$ and the average annual temperature is about $6.9^{\circ} \mathrm{C}$ (Emck 2007).

\subsection{Material and methods}

A $492 \mathrm{~cm}$ long sediment core was raised with a Livingstone piston-corer near the central position of the lake (ca. $5 \mathrm{~m}$ water depth) from an inflatable rubber raft (Fig. 4.2). One meter long core sections were retained in core tubes and stored under dark and cold $\left(+4{ }^{\circ} \mathrm{C}\right)$ conditions before processing.

\begin{tabular}{llccc}
\hline Lab. code & Dated material & Core depth & ${ }^{14}$ C yr BP & cal yr BP \\
& & & & \\
\hline Erl-8896 & Bulk sample & $96 \mathrm{~cm}$ & $1887 \pm 38$ & $1770(1630-1875)$ \\
Erl-8895 & Bulk sample & $278 \mathrm{~cm}$ & $4603 \pm 45$ & $5170(4990-5445)$ \\
Erl-11032 & Bulk sample & $360 \mathrm{~cm}$ & $6822 \pm 88$ & $7620(7460-7790)$ \\
Erl-8375 & Bulk sample & $450 \mathrm{~cm}$ & $9262 \pm 81$ & $10,380(10,225-10,555)$ \\
\hline
\end{tabular}

Table 4.1: AMS-Radiocarbon dates and calibrated ages for the lake core from Laguna Rabadilla de Vaca.

Four subsamples (bulk) were taken for Accelerator Mass Spectrometer (AMS) radiocarbon dating from the core sections (Tab. 4.1). Radiocarbon ages were calibrated with Calib 5.0.2 (Stuiver and Reimer 1993) using the southern hemisphere calibration curve (McCormac et al. 2004). Median ages of the $2 \sigma$ distribution were used for the age-depth model. The series of four AMS dates shows a consistent age-depth-model (Fig. 4.3).

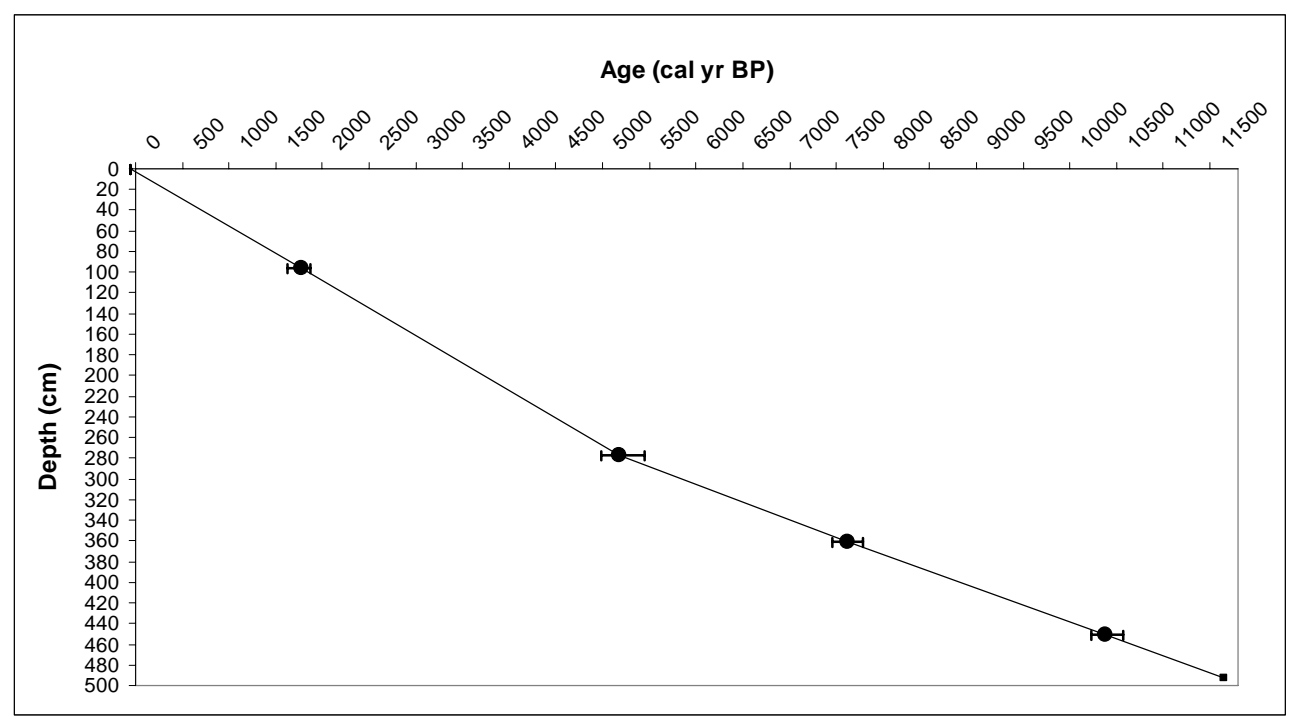

Figure 4.3: Age-depth model (cal yr BP / core depth in $\mathrm{cm}$ ) of Laguna Rabadilla de Vaca sediment core.

From the sediment core in total 52 subsamples $\left(0.25 \mathrm{~cm}^{3}\right)$ were taken for palynological and charcoal analyses mainly at $10 \mathrm{~cm}(5 \mathrm{~cm})$ intervals along the core sections. All samples were processed with standard analytical methods (Faegri and Iverson 1989). Exotic Lycopodium spores were added to each sample before treatment for calculation of pollen and charcoal influx rates. About 300 pollen grains were counted for each sample. The pollen sum includes tree-, shrub- and herb pollen and excludes spores. Pollen identification relied on the reference collection from H. Behling with about 3000 neotropical species, literature (Behling 1993; 
Hooghiemstra 1984) and on a reference collection with about 300 species collected during fieldwork and at the herbarium of the ECSF research station.

The ecological grouping of the identified pollen taxa into lower and upper mountain rainforest, subparamo and paramo has been carried out according to available data from literature (Bussmann 2001, 2005; Homeier and Werner 2005; Lozano et al. 2003).

Pollen and spore data are presented in pollen diagrams as percentages of the pollen sum. Pollen concentration (grains $/ \mathrm{cm}^{3}$.) and influx (grains $/ \mathrm{cm}^{2} / \mathrm{yr}$ ) were calculated as well. Carbonized particles $(10-150 \mu \mathrm{m})$ were counted on pollen slides and presented as influx (particles $/ \mathrm{cm}^{2} / \mathrm{yr}$ ). The software TILIA, TILIAGRAPH and CONISS were used for illustration of the pollen and spore data (Grimm 1987). The total number of identified different pollen and spore types is 108. The pollen diagram (Fig. 4.4) shows records of the most abundant pollen and spore taxa. Figure 4.5 illustrates records of the ecological groups, the pollen sum, the pollen concentration and the pollen and charcoal influx.

Non-destructively magnetic susceptibility $(\kappa)$ scanning was performed on split cores with a Bartington MS2F point sensor at $1 \mathrm{~cm}$ resolution. Also non-destructively, an Avaatech XRFscanner provided semi-quantitative analyses of Al, Si, S, K, Ca, Ti, Mn and Fe (Richter et al. 2006; Tjallingii et al. 2007) in $1 \mathrm{~cm}$ depth intervals (Fig. 4.6). Values are given in total counts (cnts).

\subsection{Results}

\section{Stratigraphy}

The $492 \mathrm{~cm}$ long lake sediment core from Laguna Rabadilla de Vaca consists of dark brown fine detritus mud (Fig. 4.5). The organic material is interrupted by four light brown $1-4 \mathrm{~cm}$ thick clay layers at 190, 280 and $295 \mathrm{~cm}$ core depth. The clay layers show an erosive base and background sedimentation at the top.

\section{Chronology and pollen zonation}

Four AMS radiocarbon dates (Tab. 4.1) were performed at the University of Erlangen/Nürnberg, Germany, providing the chronological control of the sediment core from Laguna Rabadilla de Vaca. The AMS date close to the base of the core at $450 \mathrm{~cm}$ sediment depth documents that the lake contains Holocene deposits. Extrapolation of the age-depthmodel shows an age of 11,700 cal yr BP at the base of the record.

The series of four AMS dates shows a consistent age-depth-model (Fig. 4.3), which indicates that sediments accumulated continuously. The average sediment accumulation rate is $0.418 \mathrm{~mm} / \mathrm{yr}$, in detail it is $0.526 \mathrm{~mm} / \mathrm{yr}(-55$ to $1770 \mathrm{cal} \mathrm{yr} \mathrm{BP}), 0.530 \mathrm{~mm} / \mathrm{yr}(1770$ to $5170 \mathrm{cal} \mathrm{yr} \mathrm{BP}), 0.343 \mathrm{~mm} / \mathrm{yr}$ (5170 to $7620 \mathrm{cal} \mathrm{yr} \mathrm{BP}$ ) and $0.326 \mathrm{~mm} / \mathrm{yr}$ (7620 to $11,700 \mathrm{cal}$ yr BP) (Fig. 4.6).

Cluster analysis of terrestrial pollen taxa produces a dendrogram that permits zonation of the record into the zones RV-1, RV-2 and RV-3 (Fig. 4.5).

\section{Description of the pollen diagram}

Zone RV-1 (490-405 cm, ca. 11,700-8990 cal yr BP) is marked by a stable representation of lower mountain rainforest (LMF) and upper mountain rainforest (UMF) pollen taxa such as Weinmannia (8-12\%), Hedyosmum (5-10\%) and Moraceae/Urticaceae (3-8\%). Subparamo taxa decreases little, Melastomataceae (5-10\%) and Asteraceae (3-8\%) show low amounts. 


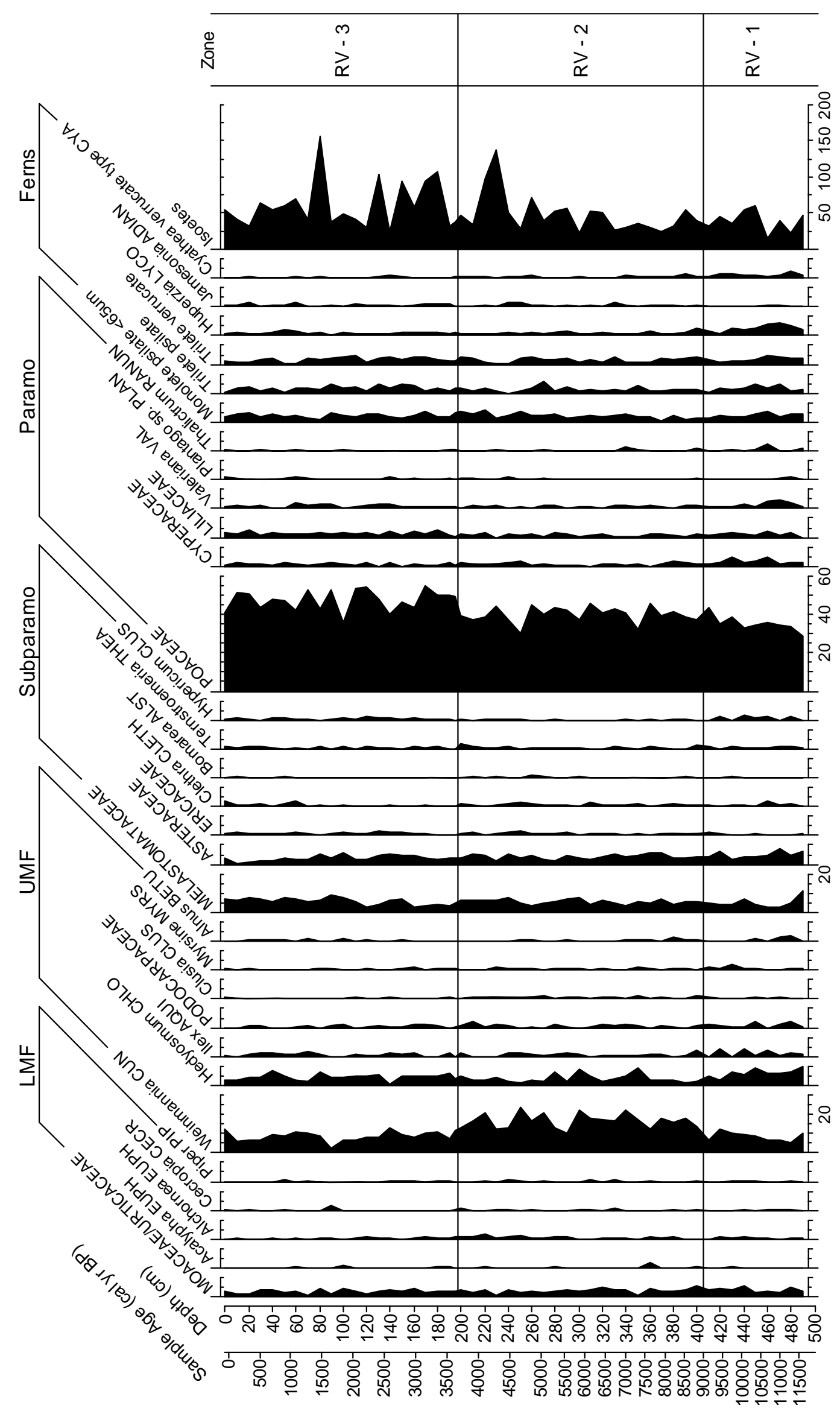

Figure 4.4: Pollen percentage diagram of Laguna Rabadilla de Vaca, showing selected pollen and spore taxa grouped into lower mountain rainforest (LMF), upper mountain rainforest (UMF), subparamo and paramo. 


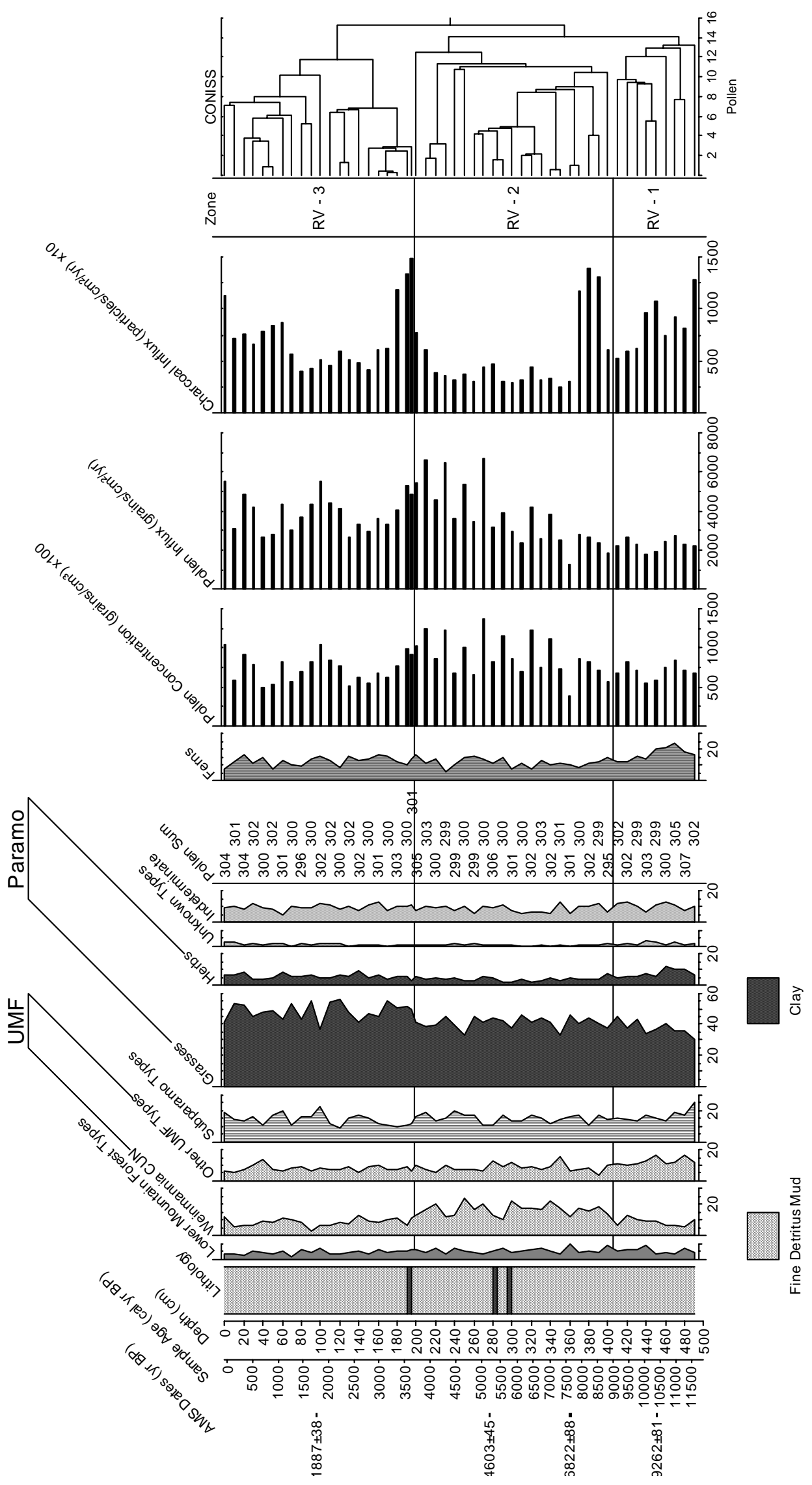

Figure 4.5: Pollen summary diagram of Laguna Rabadilla de Vaca, showing radiocarbon dates, lithology, sums of ecological groups, pollen sum, records of pollen concentration, pollen and charcoal influx and the CONISS dendrogram (Based on pollen taxa). 


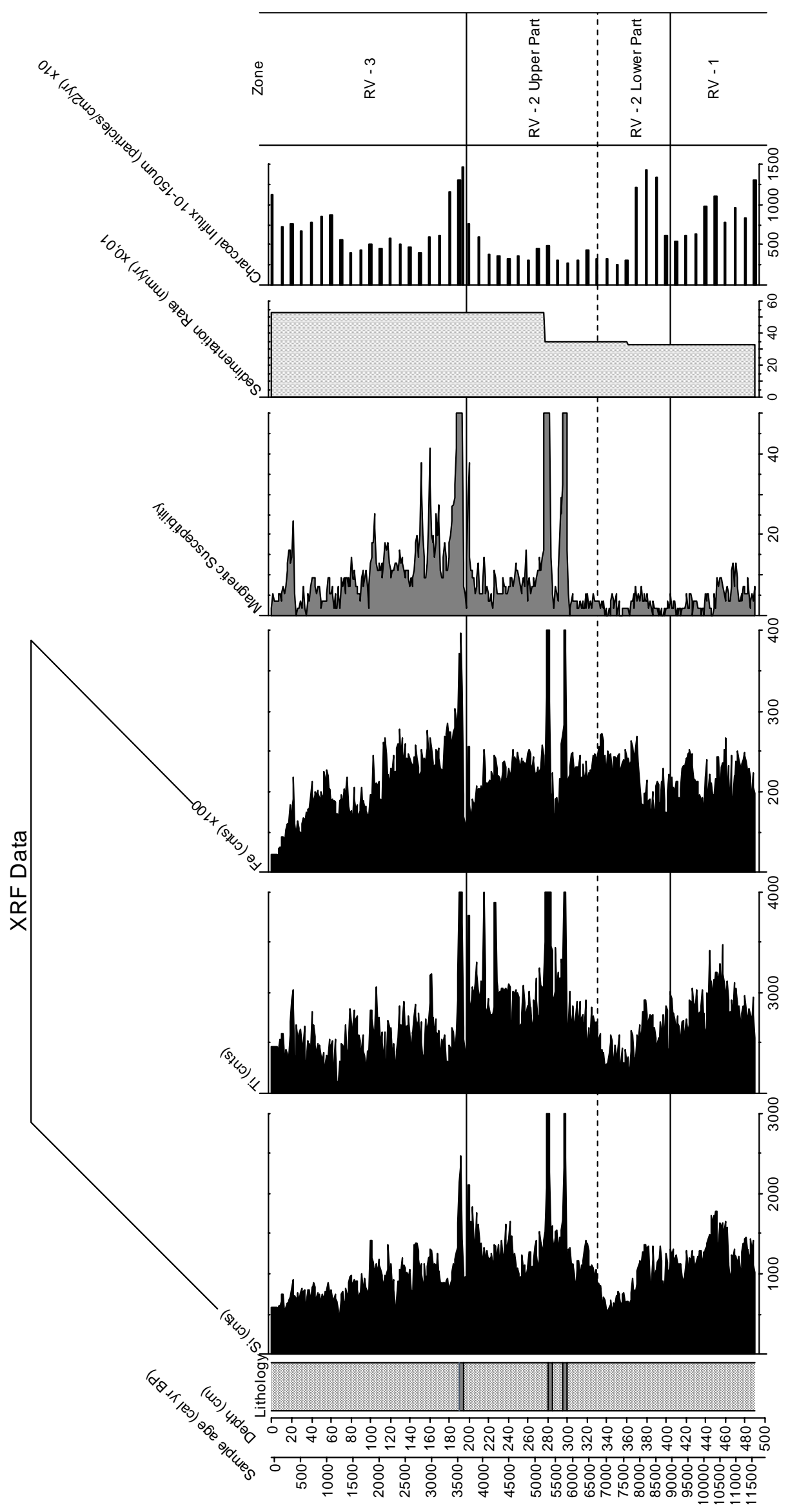

Figure 4.6: XRF-data, physical properties and charcoal influx of Laguna Rabadilla de Vaca. 
Paramo pollen are well represented, especially Poaceae (30-40\%). Cyperaceae, Liliaceae, Valeriana and Thalictrum (all 1-5\%) show low values. Fern spores (12-25\%) show highest amounts in this zone, especially Huperzia (2-8\%). Pollen concentration (150,000-320,000 grains $\left./ \mathrm{cm}^{3}\right)$ is stable. Pollen influx $\left(6000-8000\right.$ grains $/ \mathrm{cm}^{2} / \mathrm{yr}$ ) is low and charcoal influx (6000-13,000 particles $/ \mathrm{cm}^{2} / \mathrm{yr}$ ) is high with a decreasing trend, in this zone.

Zone RV-2 (405-197.5 cm, ca. 8990-3680 cal yr BP) is marked by a low representation of LMF pollen, e.g., Moraceae/Urticaceae (3-8\%). UMF pollen show highest amounts in this zone, especially Weinmannia (12-25\%). Hedyosmum (3-10\%) is low represented. Subparamo taxa such as Melastomataceae (5-8\%) and Asteraceae (3-8\%) show stable values. Paramo pollen are well represented, especially Poaceae (35-45\%). Cyperaceae, Liliaceae and Valeriana (all 1-3\%) show low amounts. Fern spores (8-15\%) show lower values as the previous zone. Pollen concentration $\left(120,000-420,000\right.$ grains $\left./ \mathrm{cm}^{3}\right)$ is high. Pollen influx (5000-20,000 grains $/ \mathrm{cm}^{2} / \mathrm{yr}$ ) is high with an increasing trend in this period. Charcoal influx (3000-14,000 particles/ $\mathrm{cm}^{2} / \mathrm{yr}$ ) is high with highest amounts between 395 and $365 \mathrm{~cm}$.

Zone RV-3 (197.5-0 cm, ca. 3680-0 cal yr BP) is marked by a low representation of LMF pollen, e.g., Moraceae/Urticaceae (1-5\%). UMF pollen such as Weinmannia (4-12\%) and Hedyosmum (3-8\%) show lower amounts as the previous zone. Subparamo taxa such as Melastomataceae $(5-10 \%)$ and Asteraceae (1-8\%) show stable values. Paramo pollen types show highest amounts in this zone, especially Poaceae (40-55\%). Liliaceae and Valeriana (both 1-3\%) show low amounts. Fern spores (8-15\%) are stable represented. Pollen concentration (180,000-260,000 grains $\left./ \mathrm{cm}^{3}\right)$ is lowest in this zone. Pollen influx (8000-16,000 grains $/ \mathrm{cm}^{2} / \mathrm{yr}$ ) is high. Charcoal influx $\left(4000-14,000\right.$ particles $\left./ \mathrm{cm}^{2} / \mathrm{yr}\right)$ is high with highest amounts at the beginning of this period.

\section{XRF-scanning and physical properties}

The zonation of the pollen diagram (RV-1, RV-2, and RV-3) was adapted for XRF data. Zone RV-2 is subdivided into a lower part (405-330 cm, 8990-6380 cal yr BP) and an upper part (330-197.5 cm, 6380-3680 cal yr BP) divided by a dashed line (Fig. 4.6). The high peaks at 190,280 and $295 \mathrm{~cm}$ core depth occur at the same depth as the thick clay layers.

A correlation matrix showed positive correlations of $\mathrm{Ti}$ to $\mathrm{K}$ and $\mathrm{Si}(\mathrm{r}=0.863$ and $0.809, \mathrm{~K}$ to Si $\mathrm{r}=0,817, \mathrm{p}<0.001)$. Al was also correlated significantly to all three elements $(\mathrm{Si}: \mathrm{r}=0.723$, $\mathrm{K}: \mathrm{r}=0.675$, Ti: $\mathrm{r}=0.633, \mathrm{p}>0.001)$ as was $\mathrm{Ca}(\mathrm{K}: \mathrm{r}=0.583, \mathrm{Si}: \mathrm{r}=0.579, \mathrm{Al}: \mathrm{r}=0.539$, Ti: $\mathrm{r}=0.501, \mathrm{p}<0.001)$. As correlations among the mentioned elements are significant and show high correlation coefficients only $\mathrm{Ti}$ and $\mathrm{Si}$ are plotted for palaeoenvironmental reconstruction. Fe only showed little correlation to these elements $(\mathrm{Al}: \mathrm{r}=0.149$, $\mathrm{Ti}: \mathrm{r}=0.160$, $\mathrm{Si}: \mathrm{r}=0.226, \mathrm{~K}: \mathrm{r}=0.240, \mathrm{p}<0.001)$. All other elements showed too low counts for interpretation. In zone RV-1 Ti and Si counts reach high amounts with a maximum between 465-440 cm. In contrast in the lower part of zone RV-2 Ti and Si values are low. The upper part of zone RV-2 and the beginning of zone RV-1 are characterised by highest values of Ti and $\mathrm{Si}$, with maxima at $330-185 \mathrm{~cm}$ before a sharp decrease to the lowest values of the record in zone RV-3. Magnetic susceptibility $(\kappa)$ shows only moderate correlation to the elements mentioned above (Ti: $r=0.44, p=0.006, \mathrm{~K}: \mathrm{r}=0.468, \mathrm{p}=0.003$, Si: $r=0,422, \mathrm{p}=0.009$, Ca: $\mathrm{r}=$ $0.28, \mathrm{p}=0.088$ and $\mathrm{Fe}: \mathrm{r}=0.215, \mathrm{p}=0.194)$ and broadly follows the peaks of the elements it is best correlated with, especially at the depths of the clay layers.

Sedimentation rate is low in RV-1 and the lower part of RV-2. In the upper part of RV-2 it rises considerably. 


\subsection{Interpretation and discussion}

The pollen record from Laguna Rabadilla de Vaca $(3312 \mathrm{~m})$ indicates that paramo vegetation exists around the core site during the whole Holocene. The bottom of the sediment core shows an age of ca. 11,700 cal yr BP. As it was impossible to recover sediments below that age we conclude that material was too coarse for recovery. Hence, this age might reflect the end of deglaciation. At Laguna Chochos (3285 m), eastern Peruvian Andes, deglaciation was locally completed at ca. 11,700 cal yr BP (Bush et al. 2005).

During the early Holocene period (RV-1, ca. 11,700-8990 cal yr BP) herb-paramo was the main vegetation type in the surrounding of Laguna Rabadilla de Vaca. The herb paramo, associated with a high number of ferns, mainly Huperzia, was rich in Poaceae, Cyperaceae, Valeriana and Liliaceae, reflecting cool and relatively wet climatic conditions.

The high values of the Ti record which commonly is regarded as an indicator for detrital input (Fey et al. submitted; Haberzettl 2006; Haberzettl et al. 2005, 2006, 2007, in press) confirm the assumption of wet conditions during RV-1. This immobile element probably was brought to the lake via fluvial processes as was demonstrated in previous studies at other lakes resulting in enhanced $\mathrm{Ti}$ input during wetter and reduced $\mathrm{Ti}$ input during drier conditions (e.g., Haberzettl et al. 2005, 2007). Hence, Ti likely reflects hydrological variations in that area. However, input of Ti during RV-1 might also be caused by a more opened vegetation cover relative to modern times, reflected by low pollen influx causing favourable conditions for erosion. Probably both factors (increased humidity and higher erosion) caused the high Ti values during the early Holocene period at the bottom of the record which are almost synchronous with the maximum of herbs and ferns.

The pollen record from El Tiro-Pass $(2810 \mathrm{~m})$, eastern Ecuadorian Andes, shows a slight expansion of subparamo and upper mountain rainforest vegetation into higher elevation during the early Holocene from ca. 11,200-8900 cal yr BP. This indicates a slow warming of climatic conditions during this period. Fern spores including tree ferns (Cyathea) expanded markedly, reflecting a change to more humid conditions at the study site (Niemann and Behling 2008c). At Laguna Chochos, a warm and wet early Holocene (ca. 11.500-9500 cal yr BP) was estimated (Bush et al. 2005).

\begin{tabular}{lccc}
\hline Author: & $\begin{array}{c}\text { Lozano } \\
\text { et al. (2003) }\end{array}$ & $\begin{array}{c}\text { Homeier and } \\
\text { Werner (2005) }\end{array}$ & $\begin{array}{c}\text { Richter and } \\
\text { Moreira-Munoz (2005) }\end{array}$ \\
\hline Vegetation unit: & & & \\
& & & \\
LMF & 2 species & 5 species & $x$ \\
UMF & 7 species & 4 species & $x$ \\
Subparomo & 5 species & 2 species & 5 species \\
Paramo & $x$ & $x$ & 4 species \\
Shrub paramo & $4-5$ species & $x$ & $x$ \\
Herb paramo & 2 species & $x$ & $x$ \\
\hline
\end{tabular}

Table 4.2: Altitudinal distribution pattern of the different Weinmannia species in the Podocarpus National park region. Data is given after (Homeier and Werner, 2005; Lozano et al. 2003) ( $\mathrm{x}=$ no data available).

The early-mid and late-mid Holocene period (RV-2, ca. 8990-3680 cal yr BP) at Laguna Rabadilla de Vaca is characterised by a strong increase of Weinmannia, indicating warmer climatic conditions due to a spread of shrub-paramo vegetation around the whole lake and/or a shift of vegetation zones into higher elevation. Weinmannia shows a widespread altitudinal distribution pattern in the Podocarpus National park region, occurring from lower mountain rainforest up to paramo vegetation zone (Homeier and Werner 2005; Lozano et al. 2003). Table 4.2 shows the number of Weinmannia species, found in different vegetation zones. The 
highest number of Weinmannia species is found in the upper mountain rainforest vegetation zone.

At modern times the slopes above Laguna Rabadilla de Vaca are covered with shrub paramo vegetation, on the more flat area near the lake herb-paramo vegetation occurs (Fig. 4.2). It might be possible, that warmer climatic conditions are responsible for a spreading of the shrub-paramo vegetation type around the whole lake, and otherwise the strong increase of Weinmannia indicates a shift of vegetation zones into higher elevation.

From ca. 8900-3300 cal yr BP an upper mountain rainforest developed at the El Tiro-Pass, indicated by an increase of Hedyosmun, Podocarpaceae, Myrsine and Ilex. This suggests a warmer climate than present day at this elevation (Niemann and Behling 2007). Ice cores from Huascaran (ca. $6050 \mathrm{~m}$ ), central Peruvian Andes show that the climate was warmest from ca. 9455-5960 cal yr BP (Thompson et al. 1995). At Lake Titicaca (3810 m), central Peruvian Andes, a dry event between ca. 9000-3100 cal yr BP is inferred from changes in the vegetation composition (Paduano et al. 2003). A well-documented early- to mid-Holocene lowstand, dated between ca. 8000-3600 cal yr BP was determined at Lake Titicaca (D'Agostino et al. 2002). Pollen-, charcoal- and radiocarbon data from Colombian inter Andean Cauca Valley $(1020 \mathrm{~m})$, indicates drier climatic conditions than present-day from ca. 9670-3030 cal yr BP (Berrio et al. 2002).

Ti suggests dry climatic conditions at Laguna Rabadilla de Vaca for the early-mid Holocene (ca. 8990-6380 cal yr BP). At Laguna Chochos a warm and wet early Holocene was interrupted by a warm-dry event that lasted from ca. 9500-7300 cal yr BP (Bush et al. 2005). The pollen record from Laguna Loma Linda $(310 \mathrm{~m})$, Colombian savannah, shows a significantly lower and seasonality stronger precipitation than today during the period from ca. 9650-6850 cal yr BP (Behling and Hooghiemstra 2000). Data from Cauca Valley indicates a dry maximum at ca. $8300 \mathrm{cal}$ yr BP, when dry forest reached maximum expansion (Berrio et al. 2002). The pollen record Yasuni National Park (220 m), Ecuadorian Amazonia, shows a long-lasting plateau of Cecropia pollen (ca. 8700-5800 cal yr BP) which is tentatively interpreted to a period of increased tree mortality, indicating a drought-prone period (Weng et al. 2002).

At the beginning of the early mid Holocene between ca. 8530-7910 cal yr BP the charcoal influx shows very high fire intensity at Laguna Rabadilla de Vaca which may reflect human burning activity near the core site. High fire intensity may responsible for an increase of erosion at this time, suggested by higher values of Ti (Haberzettl et al. 2006). Fires on the El Tiro mountains slopes may originate from anthropogenic burning by hunting activities in the dry forest area of the Loja basin after ca. 8000 cal yr BP (Niemann and Behling 2008c). For example, in the Sabana de Bogota (Colombia) the presence of Amerindians could be established from ca. 14,800 cal yr BP onward and possibly even before that time (Van der Hammen and Urrego 1978).

Ti suggests wetter climatic conditions for the late-mid Holocene (ca. 6380-3680 cal yr BP). Landslides at the slopes above Laguna Rabadilla de Vaca, contemporaneous to the peaks in Ti, probably caused by strong precipitation events, are responsible for the thick clay layers at 190, 192, 280 and $295 \mathrm{~cm}$ sediment depth and confirm an increase in humidity. This is also probably the reason for the increase in sedimentation rate from 0.34 to $0.52 \mathrm{~mm} / \mathrm{yr}$. The occurrence of the shift in sedimentation rate not until $278 \mathrm{~cm}$ sediment depth/5300 cal yr BP instead of at $298 \mathrm{~cm}$ sediment depth $/ 5800 \mathrm{cal} \mathrm{yr} \mathrm{BP}$ as indicated by $\mathrm{Ti}$, presumably is an artefact of the age-depth model as this is the subsequent dating above the actual increase. The clay layer at $280 \mathrm{~cm}$ was counted for pollen and spores. The high occurrence of shrub pollen, ca. 75\%, especially Weinmannia (30\%), Hedyosmum and Melastomataceae (both 8-10\%), low values of Poaceae $(10 \%)$ and ferns $(2 \%)$, as well as the missing of Isoetes deliver the slopes as the origin of this sediment. The clay layer shows an erosive base and background sedimentation at the top, suggesting a rapid sedimentation event. 
Maximum Holocene lake level at Lake Aricota $(2800 \mathrm{~m})$, central Peruvian Andes, was attained before ca. $7000 \mathrm{cal} \mathrm{yr} \mathrm{BP}$ and ended ca. $2800 \mathrm{cal} \mathrm{yr} \mathrm{BP} \mathrm{(Placzek} \mathrm{and} \mathrm{Quade} \mathrm{2001).}$ The pollen record from Laguna Loma Linda shows during the period from ca. 6850-3900 cal yr BP, that rainforest taxa increased markedly, reflecting an increase in precipitation (Behling and Hooghiemstra 2000). The pollen record Yasuni National Park shows wet climatic conditions from ca. 5800-4900 cal yr BP (Weng et al. 2002).

From the beginning of the late Holocene period (RV-3, ca. 3680-0 cal yr BP) a Poaceae dominated (40-55\%) herb-paramo reflecting cooler climatic conditions expanded at Laguna Rabadilla de Vaca until modern times. A decrease of Si and Ti points to drier conditions during the whole late Holocene, relative to the late mid Holocene period. At the El Tiro-Pass the modern subparamo vegetation became established since $3300 \mathrm{cal}$ yr BP (Niemann and Behling 2008c).

The very high charcoal influx at the beginning of this zone may be suggesting human activities by uncontrolled burning near Laguna Rabadilla de Vaca. The high number of Poaceae may be a result of these burning activities in coherence with the cooler and drier climatic conditions. First human activity in the region of Loja is dated by around $4000 \mathrm{cal}$ yr BP. Since then the native Palta culture established around Loja and Zamorra (Guffroy 2004). Maximum Holocene lake level at Lake Aricota was attained before ca. 2800 cal yr BP. Moderately high lake levels occurred at ca. 1600 and ca. $1230 \mathrm{cal}$ yr BP (Placzek and Quade 2001).

In opposite, a moister late Holocene is described in other publications. The pollen record from Laguna Loma Linda shows a continued increase of rainforest taxa from ca. 3900-2300 cal yr BP, precipitation was still increasing and the length of the annual dry period possibly shortened. From ca. 2300 cal yr BP onwards, grass savannah expanded which reflects increased human impact on the vegetation (Behling and Hooghiemstra 2000). The pollen record of the Yasuni National Park shows wet climatic conditions from ca. 3700-1000 cal yr $\mathrm{BP}$ and dry climatic conditions from ca. $1000 \mathrm{cal}$ yr BP to present (Weng et al. 2002).

Therefore, it is not well understood if the drier climatic conditions at Laguna Rabadilla de Vaca in the late Holocene are regional phenomena.

The Fe record which was also interpreted as an indicator for fluvial terrigenuous sediment influx in other studies (e.g., Lamy et al. 2001, 2004; Richter et al. 2006) cannot be applied as climate proxy at Laguna Rabadilla de Vaca. While Fe and Ti are closely related in the terrigenuous fraction, reduced $\mathrm{Fe}$ is prone to diagenetic remobilization whereas $\mathrm{Ti}$ is inert to diagenetic processes (Granina et al. 2004; Richter et al. 2006) which probably explain the different patterns of $\mathrm{Ti}$ and $\mathrm{Fe}$ at Laguna Rabadilla de Vaca. However, the signal of clastic input of $\mathrm{Fe}$ can at least be traced at the depths of the clay layers. Though the correlation coefficient between $\mathrm{Fe}$ and $\kappa$ is rather low the same seems to be the case for $\kappa$ as reductive dissolution of ferric iron components also has a strong impact on the rock magnetic properties of the sediment (Kasten et al. 2003) and rock-magnetic parameters are not palaeoclimate proxies per se (Geiss et al. 2003). $\kappa$ can only be used as indicator for detrital input at obvious parts of the record, i.e., at the depths of the clay layers.

\subsection{Conclusions}

During the early Holocene (11,700-8990 cal yr BP) climatic conditions were cool and relatively wet. Herb-paramo was the main vegetation type at the Laguna Rabadilla de Vaca. The herb-paramo, associated with a high number of ferns, mainly Huperzia, was rich in Poaceae, Cyperaceae, Valeriana and Liliaceae.

The mid Holocene (8990-3680 cal yr BP) is characterised by warmer climatic conditions than modern times. Drier climatic conditions for the early-mid Holocene (8990-6380 cal yr BP) and wetter climatic conditions for the late-mid Holocene (6380-3680 cal yr BP) are 
inferred. A strong increase of Weinmannia, reflects a spread of a shrub-paramo vegetation type around the whole lake and/or a shift of vegetation zones into higher elevation.

Cooler and drier climatic conditions relative to the late-/mid Holocene period become established since the beginning of the late Holocene (3680 cal yr BP). A Poaceae (40-55\%) dominated herb-paramo expanded until modern times.

Acknowledgement: Felix Matt (research station leader) is thanked for his logistical support and for his information about the study region. Thanks are also to Jürgen Homeier for using his species lists and his collected flower samples and to Achim Bräuning, Henrik Stark and Markus Hofmann for accompanying us on the three days long field trip from Vilcabamba to Laguna Rabadilla de Vaca. Thanks to the University of Bremen for using the XRF- and MSscanner. The project FOR 402/D1 (Vegetation-, climate- and fire dynamics in the Podocarpus National park region) is kindly funded by the Deutsche Forschungsgemeinschaft (DFG). 


\title{
5. Late Pleistocene and Holocene vegetation development, climate variability and human impact inferred from Cocha Caranga multi-proxy records in the southeastern Ecuadorian Andes
}

Palaeogeography, Palaeoclimatology, Palaeoecology (in review)

Holger Niemann, Hermann Behling

Department of Palynology and Climate Dynamics, Albrecht-von-Haller-Institute for Plant Sciences,University of Göttingen, Untere Karspüle 2, 37073 Göttingen, Germany

\begin{abstract}
To study the late Pleistocene and Holocene vegetation, climate and fire dynamics of mountain rainforest and paramo ecosystems, as well as human impact we present two sediment cores and a soil core from Cocha Caranga area (2710 m elevation) in the Podocarpus National Park, southeastern Ecuadorian Andes.

Palaeoenvironmental changes were investigated by pollen, spore, algae and charcoal analyses. During the transition from late Pleistocene to early Holocene (ca. 14,500-9700 cal yr BP) upper mountain forest vegetation (mainly Weinmannia) expands, due to increasing temperatures and moisture. The expansion ends with increasing fires at ca. $9700 \mathrm{cal} \mathrm{yr}$ BP, open grassy vegetation established now, indicating that vegetation reacts highly sensitive on fire intensity during the past. The green algae Botryococcus braunii, Isoetes and Cyperaceae were used to identify lake level fluctuation to reconstruct Holocene wet/dry phases. Drier climatic conditions occurred from ca. 9700 to $6900 \mathrm{cal} \mathrm{yr} \mathrm{BP}$ and from ca. 4200 to $1300 \mathrm{cal} \mathrm{yr}$ BP. From ca. 6900 to 4200 cal yr BP and from ca. 1300 cal yr BP to modern times, wetter climatic conditions occurred. The high fire intensity from ca. 9700 to 1300 cal yr BP was interpreted as a period of strong human impact. After the decrease of fires the modern vegetation, characterised of open grassy areas with forest patches and small mires, established around Laguna Cocha Caranga.
\end{abstract}

Keywords: Ecuador, pollen analysis, mountain rainforest, fire history, human impact, Botryococcus 


\subsection{Introduction}

The Ecuadorian Andes harbour the most species rich ecosystems on earth (Barthlott et al. 2005). Despite its high biodiversity huge areas have been strongly affected during the last decades in particular. Natural vegetation regeneration and sustainable management is urgently needed as well as conservation of less degraded areas.

To study the highly diverse mountain ecosystems in southeastern Ecuador, extended research has been carried out in the framework of the "Deutsche Forschungsgemeinschaft" (DFG) research group "Tropical Mountain Ecosystems" focusing on Podocarups National Park (Beck et al. 2008a). Currently (2007-2010) more than 25 different research group are working in this area. Studies on recent vegetation and their pollen rain, e.g. collected in pollen traps over on year, provide important background information in the interpretation of late Quaternary pollen records (Niemann and Behling 2008a). Palaeoecological work under analysing more than 10 different lake, peat and soil cores in the Podocarpus National Park region started in 2005 (Niemann and Behling 2008b; Niemann and Behling 2008c; Niemann et al. 2007). This palaeoecological information is needed to understand the natural composition and dynamics of modern ecosystems for proper management and conservation.

A few palaeoenvironmental records are available from southern Ecuador and neighbouring countries (Fig. 5.1). For example from the Colombian Cauca Valley (Berrio et al. 2002), from Laguna Loma Linda located in the transition zone between the savannah of the Llanos Orientales and the Amazon rainforest in Colombia (Behling and Hooghiemstra 2000), from Lake Ayauch in the southeastern part of Ecuadorian Amazonia (Bush and Colinvaux 1988), from Rio Napo in the northwestern Amazon basin of Ecuador (Colinvaux et al. 1988a), from Lake Yambo at the Inter-Andean Plateau of Ecuador (Colinvaux et al. 1988b), from Yasuni National Park Ecuadorian Amazonia (Weng et al. 2002), from Lake Surucucho in the Las Cajas Nationa Park at the eastern flank of the western Ecuadorian Andes (Colinvaux 1997), from Laguna Chochos, eastern Peruvian Andes (Bush et al. 2005), from Huascaran (ice cores) in the central Peruvian Andes (Thompson et al. 2003) and from different lakes of central Peruvian Andes (Hansen et al. 1994).

In this study we want to address following main questions: (1) How developed vegetation during the past and is the grassy vegetation with forest patches natural or caused by humans? (2) Could the pollen, spore, algae and charcoal records offer over-regional climatic signals, in comparison to other core sites? (3) Played fires a role during the past and how strong was human impact?

\subsection{Site description}

\section{Location}

The Andes of southern Ecuador and northern Peru include the so-called Andean depression (Depression de Giron-Cuenca in Ecuador and Huancabamba in Peru). The main peaks of the mountains in this region reach up to about $4000 \mathrm{~m}$. Active volcanoes are absent (Richter and Moreira-Munoz 2005). The southern Cordillera Real is mainly built up by the geologic unit of the "Zamora series", consisting of Palaeozoic metamorphic rocks of widely varying metamorphic grade. Local bedrock is dominated by semipelites, quartzites and black phylites with some granitic intrusions (Litherland et al. 1994).

The study area (Fig. 5.1) is located on the western slope of the eastern Cordillera (Cordillera Real) $8 \mathrm{~km}$ southeast of the city of Loja $(2200 \mathrm{~m})$, in the Podocarpus National Park.

Laguna Cocha Caranga, at $2710 \mathrm{~m}$ elevation ( $4^{\circ} 02^{\prime} 45.1^{\prime \prime} \mathrm{S}, 079^{\circ} 09^{\prime} 34.5^{\prime \prime} \mathrm{W}$ ) is exposed just below a mountain ridge, in NW-SE orientation, in a small depression. The depth in the middle of the lake is ca. $2 \mathrm{~m}$ and the size is about $2000 \mathrm{~m}^{2}$. The core site Cocha Caranga mire 


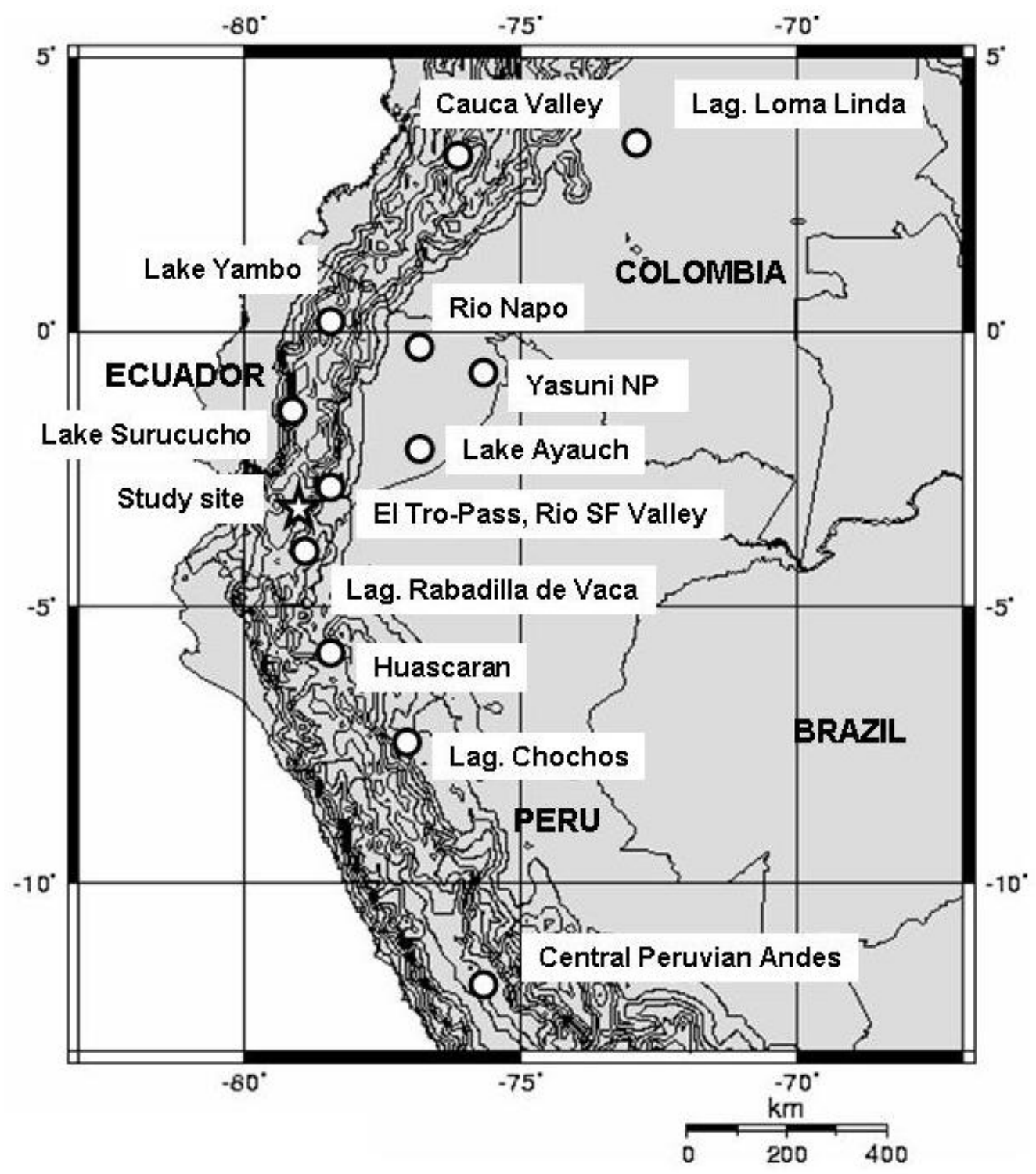

Figure 5.1: Map of central northwestern tropical South America, showing the study site (star) and other locations discussed in the text (circles). The map was created under using OMC (www.aquarius.geomar.de).

is small bog from ca. $50 \mathrm{~m}^{2}$, directly at the northern shore of the lake. The core site Cocha Caranga forest is a forest patch of about $500 \mathrm{~m}^{2}$, southeast and just $10 \mathrm{~m}$ below the lake. The three core locations are shown in Figure 5.2.

The Cocha Caranga core sites are located in the UMF vegetation zone, below the tree line. The surrounding landscape is characterised by grassy vegetation with forest patches. The valleys and slopes below the lake are strongly degraded by pastures, many terraces at lower slope areas may be point to agricultural use in past. Following the mountain ridge to the southeast, closed forest vegetation occurs after $500 \mathrm{~m}$.

\section{Modern vegetation}

The mountain rainforest ecosystems is descript for the Podocarpus National Park region after Bussmann (2001, 2005) and Lozano et al. (2003). The lower mountain rainforest (LMF) between ca. 1800-2150 m with an extremely diverse, 2-storied tree stratum and is composed of a numerous 20-35 m tall tree species. Characteristic species are e.g., Alzetea verticillata (Alzataceae), Graffenrieda miconioides (Melastomataceae) and Myrcianthes sp. 


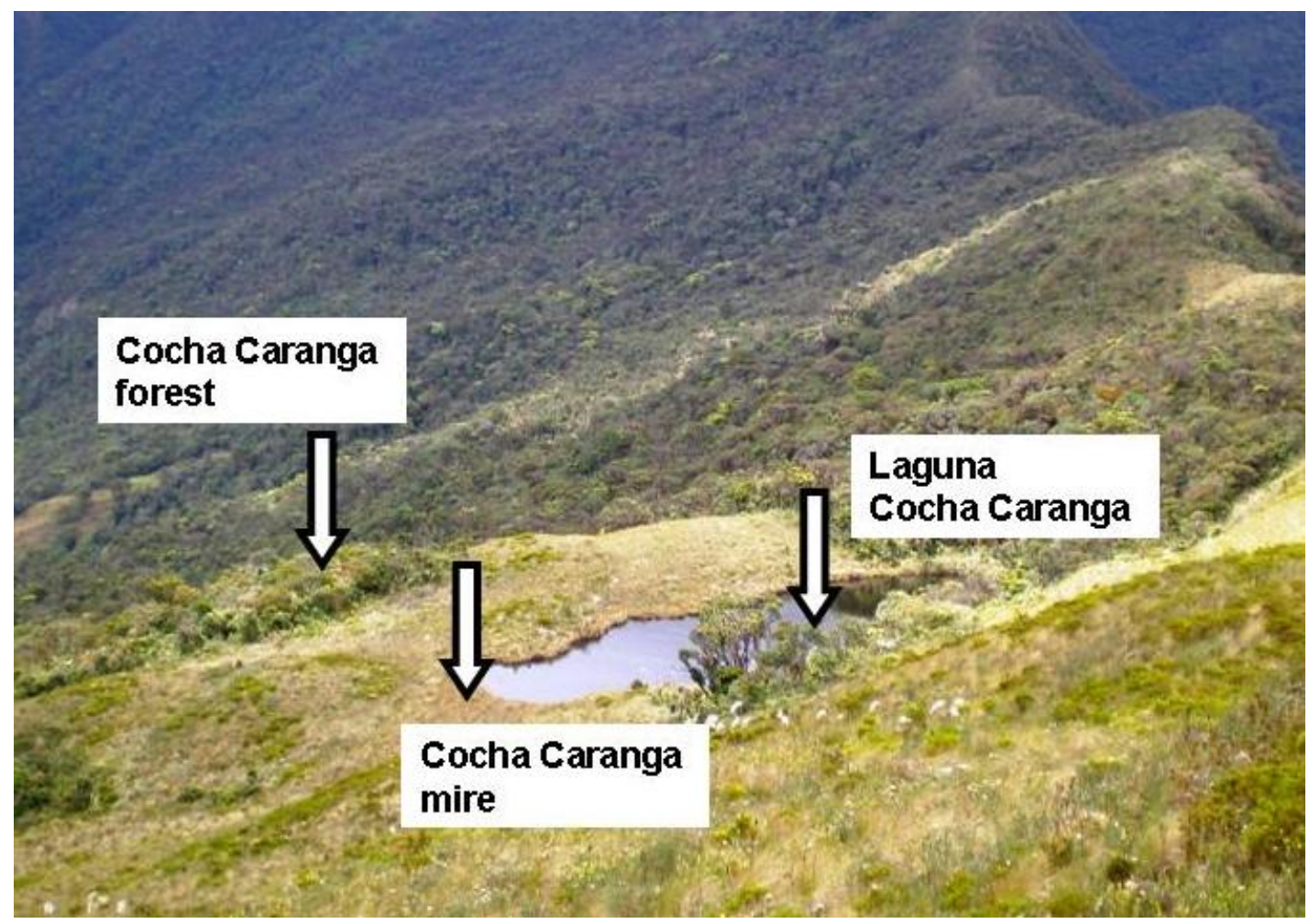

Figure 5.2: Photograph of Laguna Cocha Caranga (from north), the three core sites are marked with an arrow.

(Myrtaceae).The upper mountain rainforest (UMF) between ca. 2100-2800 m, replaced by a low, monotypic formation, with only one tree stratum between 5-10 m, rarely up to $15 \mathrm{~m}$ tall. Characteristic trees are Purdiaea nutans (Cyrillaceae), Myrica pubescens (Myricaceae) and Myrsine andina (Myrsinaceae). Between ca. 2800-3100 m, subparamo is present, characterised by Puya nitida (Bromeliaceae), Brachyotum rotundifolium (Melastomataceae) and Oritrophium peruvianum (Asteraceae). The shrubs and herbs grow up to $1 \mathrm{~m}$ height, individual shrub species can be 2-3 $\mathrm{m}$ tall.

After Lozano et al. (2003), two different types of modern paramo ecosystems occurs in the Podocarpus National Park region. The herb paramo (Paramos herbaceos), located at ca. 32003400 m, is rich in Neurolepis nana, Calamagrostis macrophylla (Poaceae) and Niphogeton dissecta (Apiaceae). The herbs and shrubs grow up from $0.2 \mathrm{~m}$ to $1 \mathrm{~m}$ height. This paramo type was found at flat slopes and concave sections as well as in ridge areas. The shrub paramo (Paramos arbustivos bajos), located at ca. 2900-3400 m, is rich in Weinmannia rollottii (Cunoniaceae), Oxalis spiralis (Oxaliaceae) and Ilex andicola (Aquifoliaceae). The shrubs and herbs grow up from $0.5 \mathrm{~m}$ to $1.2 \mathrm{~m}$ height. This paramo type was found mainly at steep slopes.

The modern tree line in central Ecuador is at ca. $3400 \mathrm{~m}$ (La Libertad), at ca. $3500 \mathrm{~m}$ (Atillo) and in northern Ecuador at ca. $3600 \mathrm{~m}$ (Guandera). At the El Tiro-Pass $8 \mathrm{~km}$ north of the core site the modern tree line is at ca. $2800 \mathrm{~m}$, this is about $600-800 \mathrm{~m}$ lower (Bader 2007). Studies of recent vegetation/modern pollen rain relationship estimated the modern tree line in the ECSF research area, $15 \mathrm{~km}$ northeast of the core site at ca. $2790 \mathrm{~m}$ (Niemann and Behling 2008a).

\section{Climate}

The climate of Ecuador is dominated by the tropical trade wind regime which is well established in the mid- and higher troposphere, with strong easterlies all over the year. The 
surface wind field is locally and regionally modified by the complex topography of the Andes and the thermal land-sea contrast at the Pacific coast. The southeastern part of Ecuador is also mainly influenced by easterlies, but westerlies occasionally occur especially in austral summer. The main rainy season lasts from April to August even if rainfall is high all through the year (Beck et al. 2008b). As part of the so-called Andean depression, all summits in the southern Ecuadorian Andes are below the snowline.

The eastern Andean mountains form a division that separates the moist eastern slopes of the Andes from the dry inner-Andean basins (e.g., the Loja- and Catamayo basin). The smallscale structure of water surplus, due to horizontal rain and cloud/fog water deposition, can lead to marked climatic gradients over a short distance. Between the eastern slopes of the eastern Cordillera and the dry valley of Catamayo, which are only $70 \mathrm{~km}$ apart, annual rainfall rates drop from over $4000 \mathrm{~mm}$ to $300 \mathrm{~mm}$ (Bendix et al. 2004). The mean annual temperature increases from Cordillera Real, crest region $\left(<9^{\circ}\right)$ to Loja $\left(15-19^{\circ}\right)$ (Beck et al. 2008b).

The ECSF research area in the upper Rio San Francisco valley, ca. $15 \mathrm{~km}$ northwest of the core site show a strong altitudinal gradient in increase of water surplus, from the valley bottom (1800 m, $2297 \mathrm{~mm})$ to summit region $(3200 \mathrm{~m}, 6701 \mathrm{~mm})$ (Bendix et al. 2008). The average precipitation rate near the El Tiro-Pass $(2880 \mathrm{~m})$, ca. $10 \mathrm{~km}$ northwest of the core site, is about $3500 \mathrm{~mm} / \mathrm{yr}$. At Cajanuma on the western slope of the eastern Cordillera $(3400 \mathrm{~m})$, $20 \mathrm{~km}$ south of the core site; it is about $5700 \mathrm{~mm}$ (Emck 2007).

Laguna Cocha Caranga is located in this transition zone, between the wet slopes of the eastern Cordillera and the dry Loja basin.

\subsection{Material and methods}

At Laguna Cocha Caranga a $58 \mathrm{~cm}$ long sediment core was raised with a Livingstone pistoncorer near the central position of the lake (ca. $2 \mathrm{~m}$ water depth) from an inflatable rubber raft, retained in core tube and stored under dark and cold $\left(+4{ }^{\circ} \mathrm{C}\right)$ conditions before processing. The uppermost $26 \mathrm{~cm}$ of the soft lake sediment was cored with a Kajak-Corer. The content of the core tupe was sampled in situ.

The peat deposit (Cocha Caranga mire) near the shore line of the lake and forest patch (Cocha Caranga forest) was cored using a manual corer (Russian Corer), for both core sides central positions were chosen. The in total three core locations are shown in Figure 5.2. Sections of $50 \mathrm{~cm}$ length were extruded on-site with split PVC tubes, wrapped with plastic film and stored under dark and cold $\left(+4{ }^{\circ} \mathrm{C}\right)$ conditions before processing. Site specific data of the three cores from Laguna Cocha Caranga site are given in Table 5.1.

\begin{tabular}{llccc}
\hline Core name & Material & Elevation & $\begin{array}{c}\text { Core } \\
\text { length }\end{array}$ & $\begin{array}{c}\text { Number of } \\
\text { identified taxa }\end{array}$ \\
\hline Laguna Cocha Caranga $(\mathrm{CL})$ & Lake sediment & $2710 \mathrm{~m}$ & $65 \mathrm{~cm}$ & 109 \\
Cocha Caranga Mire $(\mathrm{CM})$ & Peat & $2710 \mathrm{~m}$ & $69 \mathrm{~cm}$ & 86 \\
Cocha Caranga Forest (CF) & Soil deposit & $2700 \mathrm{~m}$ & $49 \mathrm{~cm}$ & 54 \\
\hline
\end{tabular}

Table 5.1: Site specific data of the three cores from Cocha Caranga.

In total, seven subsamples (soil organic matter and bulk) were taken for Accelerator Mass Spectrometer (AMS) radiocarbon dating. Radiocarbon ages were calibrated with CalPal (Weninger et al. 2004).

From the sediment core and the contents of the Kajak-Corer of Laguna Cocha Caranga in total 34 subsamples $\left(0.25 \mathrm{~cm}^{3}\right)$ were taken for palynological and charcoal analyses mainly at 2 $\mathrm{cm}(1 \mathrm{~cm})$ intervals along the core sections. The overlapping of the two core sections was 
fixed by the marked decrease of the algae Botryococcus between 22 and $24 \mathrm{~cm}$ core depth. From the sediment core Cocha Caranga mire and from the soil core Cocha Caranga forest, in total 31 subsamples $\left(0.25 \mathrm{~cm}^{3}\right)$ were taken at $4 \mathrm{~cm}$ intervals along the core sections. All samples were processed with standard analytical methods (Faegri and Iverson 1989). Exotic Lycopodium spores were added to each sample before treatment for calculation of pollen, algae and charcoal concentration (grains, particles or individuals $/ \mathrm{cm}^{3}$ ) and for calculation of pollen and charcoal influx (grains or particles $/ \mathrm{cm}^{2} / \mathrm{yr}$ ). About 300 pollen grains were counted for each sample. The pollen sum includes trees-, shrub- and herb pollen and excludes fern spores, spores of Isoetes and Sphagnum and the algae Botryococcus. Pollen of Cyperaceae also was excluded in the pollen sum. Pollen identification relied on the reference collection from the second author with about 3000 neotropical species and literature (Behling 1993; Hooghiemstra 1984) and on a reference collection with about 300 species collected during the fieldwork and from the herbarium of the ECSF research station.

The ecological grouping of the identified pollen taxa into lower and upper mountain forest, subparamo and paramo has been carried out according to available data from literature (Bussmann 2001, 2005; Homeier and Werner 2005; Lozano et al. 2003).

Pollen and spore data are presented in pollen diagrams as percentages of the pollen sum. Carbonized particles $(10-150 \mu \mathrm{m})$ and the algae individuals of Botryococcus were counted on pollen slides and presented as concentrations and influx rates. The software TILIA, TILIAGRAPH and CONISS were used for illustration of the pollen and spore data (Grimm 1987). The total number of identified different pollen and spore types is given in Table 5.1. Cluster analysis (CONISS) of terrestrial pollen and spore taxa produces a dendrogram which help to identify the pollen zones.

\subsection{Results}

\section{Stratigraphy and chronology}

The in total $65 \mathrm{~cm}$ long sediment section from Laguna Cocha Caranga consists of dark brown fine detritus mud $(0-22 \mathrm{~cm})$ and decomposed brown organic material with an increasing content of clay $(22-28 \mathrm{~cm})$. The lowermost part of the core consists of light brown to grey silty clay with organic contents $(28-65 \mathrm{~cm})$. The $69 \mathrm{~cm}$ long sediment core from Cocha Caranga mire consists of light brown peat $(0-10 \mathrm{~cm})$, brown organic material with roots $(10-$ $38 \mathrm{~cm})$ and dark brown decomposed organic rich material $(38-69 \mathrm{~cm})$. The $49 \mathrm{~cm}$ long sediment core from Cocha Caranga forest consists of brown organic material with roots $(0-26$ $\mathrm{cm})$ and dark brown decomposed organic rich material $(26-49 \mathrm{~cm})$.

In total, five AMS radiocarbon dates are available (Tab. 5.2), three for the sediment core of Laguna Cocha Caranga and two for the sediment core Cocha Caranga mire. For the soil core Cocha Caranga forest, one sample of soil organic matter was dated. The dated material was contaminated by recent organic material (decomposed roots and rootlets) and cannot be used for the chronology. Another sample (charcoal) has been submitted for AMS radiocarbon dating. Dating of fractions of soil organic matter obtained by alkali-acid extraction is promising, but which fraction renders the most accurate $14 \mathrm{C}$ dates is still subject to debate (Tonneijck et al. 2006).

The AMS radiocarbon dates were performed at the University of Erlangen/Nürnberg, Germany, providing the chronological control of the sediment cores from Laguna Cocha Caranga and Cocha Caranga mire. The AMS date $10636 \pm 38$ yr BP $(12569 \pm 140$ cal yr BP $)$ close to the base of the sediment core from Laguna Cocha Caranga at $61 \mathrm{~cm}$ sediment depth documents that the lake contains late Pleistocene deposits. Extrapolation show an age of ca. 


\begin{tabular}{lllccc}
\hline Core name & Labor code & Dated material & $\begin{array}{c}\text { Core } \\
\text { depth }\end{array}$ & ${ }^{14}$ C yr BP & cal yr BP \\
& & & & & \\
\hline Laguna Cocha Caranga & Erl-11035 & Bulk sample & $23 \mathrm{~cm}$ & $1208 \pm 48$ & $1149 \pm 70$ \\
Laguna Cocha Caranga & Erl-11395 & Bulk sample & $55 \mathrm{~cm}$ & $7413 \pm 52$ & $8256 \pm 58$ \\
Laguna Cocha Caranga & Erl-11036 & Bulk sample & $61 \mathrm{~cm}$ & $10636 \pm 38$ & $12569 \pm 140$ \\
Cocha Caranga Mire & Erl-11393 & Bulk sample & $43 \mathrm{~cm}$ & $259 \pm 44$ & $301 \pm 114$ \\
Cocha Caranga Mire & Erl-11394 & Bulk sample & $67 \mathrm{~cm}$ & $1636 \pm 46$ & $1523 \pm 71$ \\
Cocha Caranga Forest & Erl-11392 & Soil organic matter & $26 \mathrm{~cm}$ & $160 \pm 35$ & \\
Cocha Caranga Forest & in preparation & Charcoal & $30 \mathrm{~cm}$ & & \\
\hline
\end{tabular}

Table 5.2: AMS-radiocarbon dates and calibrated ages of the three cores from Cocha Caranga.

$14,500 \mathrm{cal} \mathrm{yr} \mathrm{BP}$ at the base of the record. The AMS date $1636 \pm 46 \mathrm{yr}$ BP $(1523 \pm 71 \mathrm{cal} \mathrm{yr}$ $\mathrm{BP})$ close to the base of the sediment core from Cocha Caranga mire at $67 \mathrm{~cm}$ documents early Holocene deposits. Extrapolation show an age of $1550 \mathrm{cal}$ yr BP at the base of the record. The age of Cocha Caranga forest soil core is still unknown and only can be presumed.

The series of AMS dates indicate that sediments accumulated continuously, a gap in the sediment core from Laguna Cocha Caranga can not be excluded finally. The deposition time (yrs/cm) is given for the sediment cores from Laguna Cocha Caranga (Fig. 5.4) and Cocha Caranga mire (Fig. 5.6).

\section{Description of the pollen diagram of Laguna Cocha Caranga (CL) (Figs. 5.3 and 5.4)}

Zone CL-1 (65-57 cm, ca. 14,500-9700 cal yr BP, 4 subsamples) show increasing amounts of upper mountain forest (UMF) and declining values of paramo taxa. Weinmannia (15-48\%) show highest amounts during this period. Hedyosmum (4-15\%), Ilex and Myrsine (both 3-6\%) are well represented. Poaceae (5-15\%), originated from paramo is relatively rare, as well as pollen of Cyperaceae (3-5\%). Pollen taxa originated from subparamo, especially Melastomataceae (5-9\%), are stable represented. Isoetes is highest show highest values (up to $100 \%)$ in this zone. Fern spores (6-37\%) show high amounts. Botryococcus concentration $\left(50,000-500,000\right.$ individuals $\left./ \mathrm{cm}^{3}\right)$ is low; pollen concentration $(200,000-7.5$ million grains $\left./ \mathrm{cm}^{3}\right)$ is highest and charcoal concentration $\left(0.1-2.5\right.$ million particles $\left./ \mathrm{cm}^{3}\right)$ rose during this period. Pollen influx (1000-10,000 grains $\left./ \mathrm{cm}^{2} / \mathrm{yr}\right)$ strongly increases and charcoal influx $\left(<5000 \mathrm{particles} / \mathrm{cm}^{2} / \mathrm{yr}\right)$ is lowest in this zone.

Zone CL-2 (57-49 cm, ca. 9700-6900 cal yr BP, 4 subsamples) show a decrease of pollen taxa originated from UMF. Weinmannia (11-15\%), Myrica, Hedyosmum, Myrsine and Ilex (all 3-8\%) show lower amounts as the previous zone. Paramo taxa, especially Poaceae increase from 10 to $38 \%$, as well as Cyperaceae (from 10 to 32\%). Isoetes is well represented $(6-15 \%)$ in this zone. Fern spores $(15-25 \%)$ are relatively frequent. Botryococcus concentration $\left(50,000-500,000\right.$ individuals $\left./ \mathrm{cm}^{3}\right)$ and pollen concentration $(0.3-1.5$ million grains $\left./ \mathrm{cm}^{3}\right)$ is relatively low, charcoal concentration $\left(3.3-7\right.$ million particles $\left./ \mathrm{cm}^{3}\right)$ is high during this period. Pollen influx (2000-45000 grains $/ \mathrm{cm}^{2} / \mathrm{yr}$ ) and charcoal influx (800032,000 particles $/ \mathrm{cm}^{2} / \mathrm{yr}$ ) are also high in this zone.

Zone CL-3 (49-37 cm, ca. 6900-4200 cal yr BP, 6 subsamples) show a relatively stable representation of mountain forest and (sub)-paramo taxa. Weinmannia (9-18\%), Myrica (525\%), Melastomataceae, Moraceae/Urticaceae, Myrsine, Ilex (all 3-6\%) and Podocarpaceae (1-6\%) are well represented. Poaceae (25-30\%) show stable amounts. Pollen of Cyperaceae $(20-40 \%)$ are frequent. Isoetes (4-12\%) show lower amounts as the preceding zone. Fern spores $(25-45 \%)$ show highest representation during this period. Botryococcus concentration 


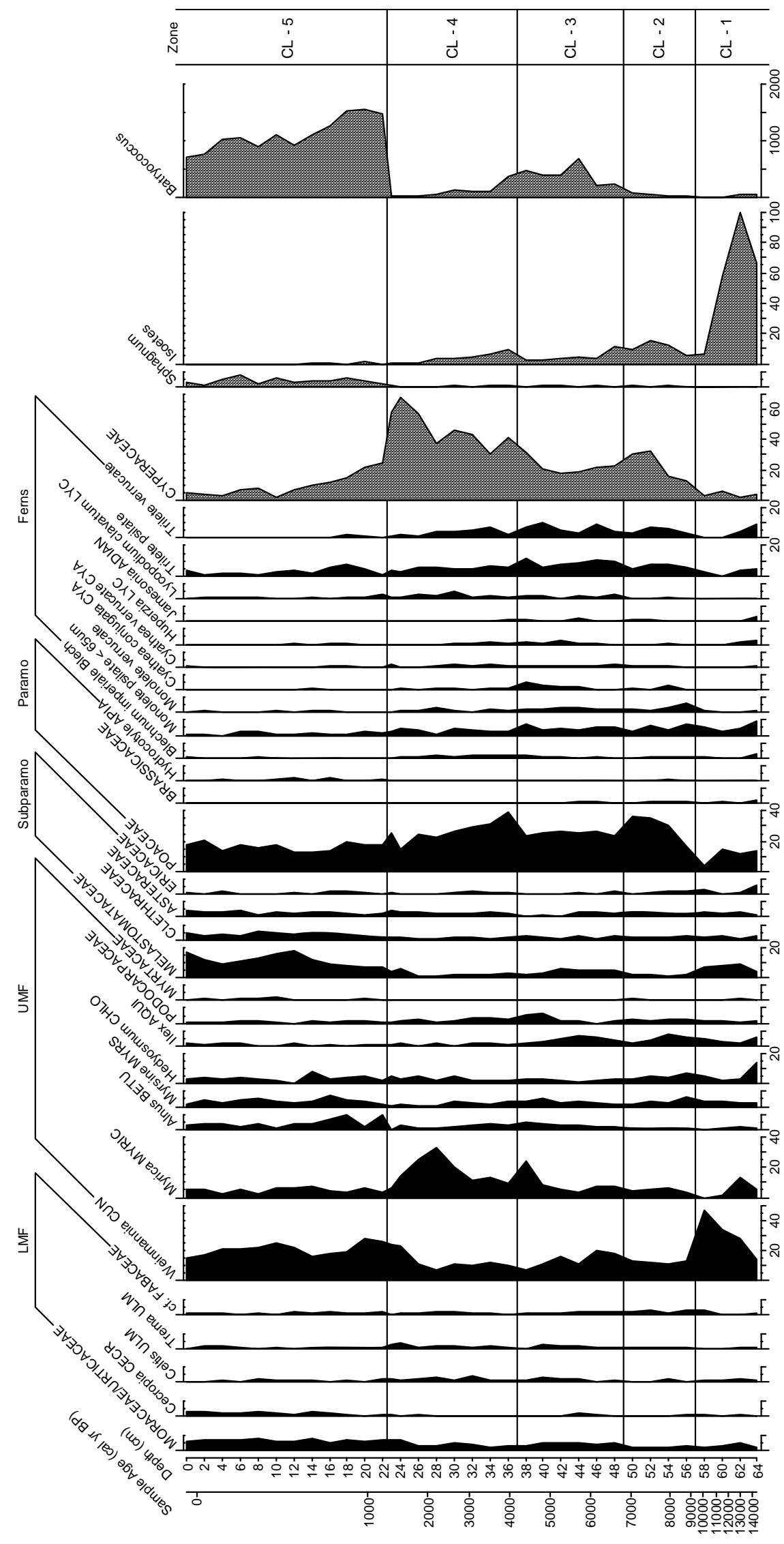

Figure 5.3: Pollen percentage diagram of the sediment core from Laguna Cocha Caranga ( $2710 \mathrm{~m})$ showing the sample ages (cal yr BP), selected pollen and spore taxa grouped into lower mountain forest (LMF), upper mountain forest (UMF), subparamo, and paramo and the pollen zones. 


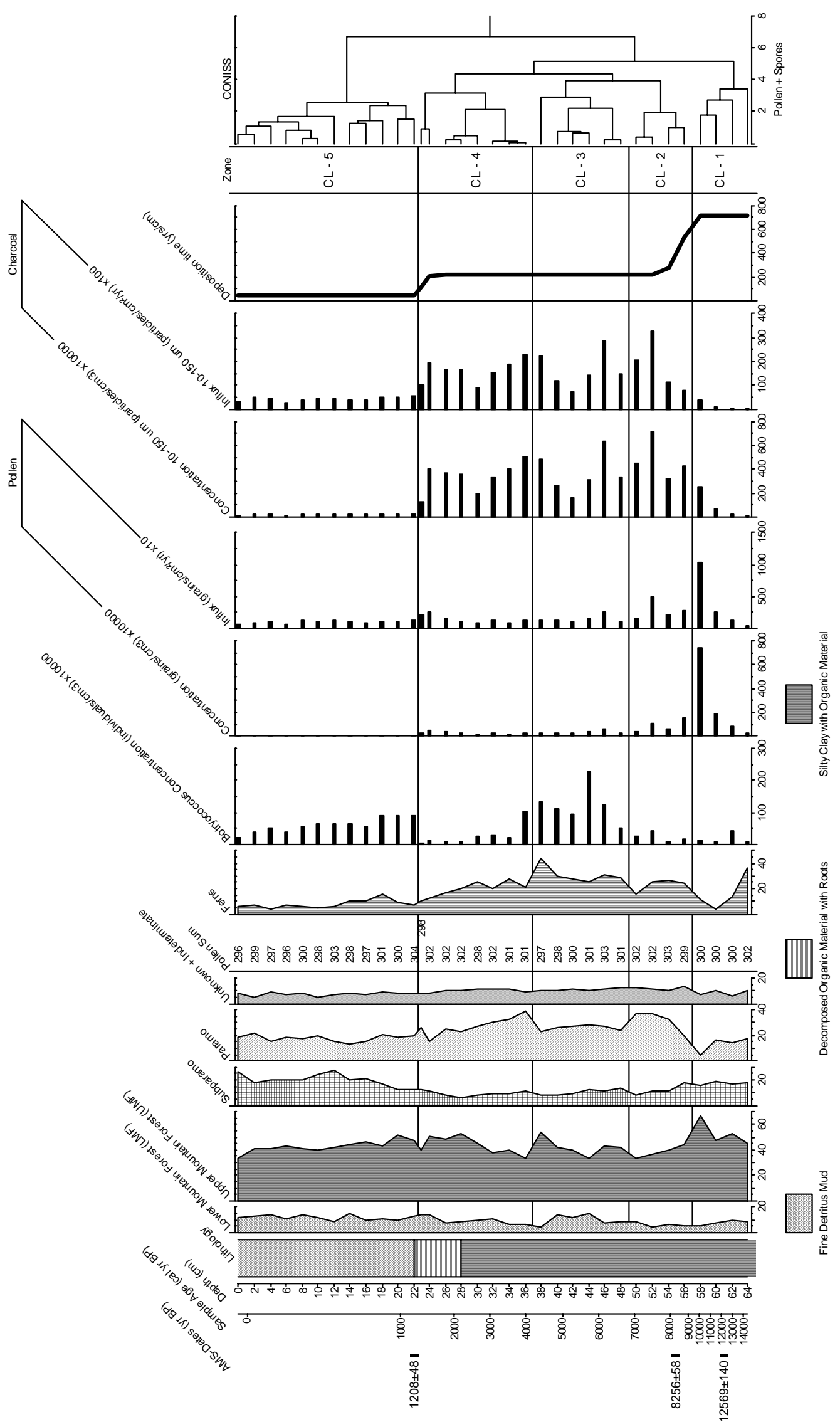

Figure 5.4: Pollen summary diagram of the sediment core from Laguna Cocha Caranga (2710 m) showing showing the AMS radiocarbon dates, sample ages (cal yr BP), the lithology, sums of ecological groups, the pollen sum, the deposition time, algae, pollen and charcoal concentration, pollen and charcoal influx, the pollen zones and the CONISS dendrogram. 


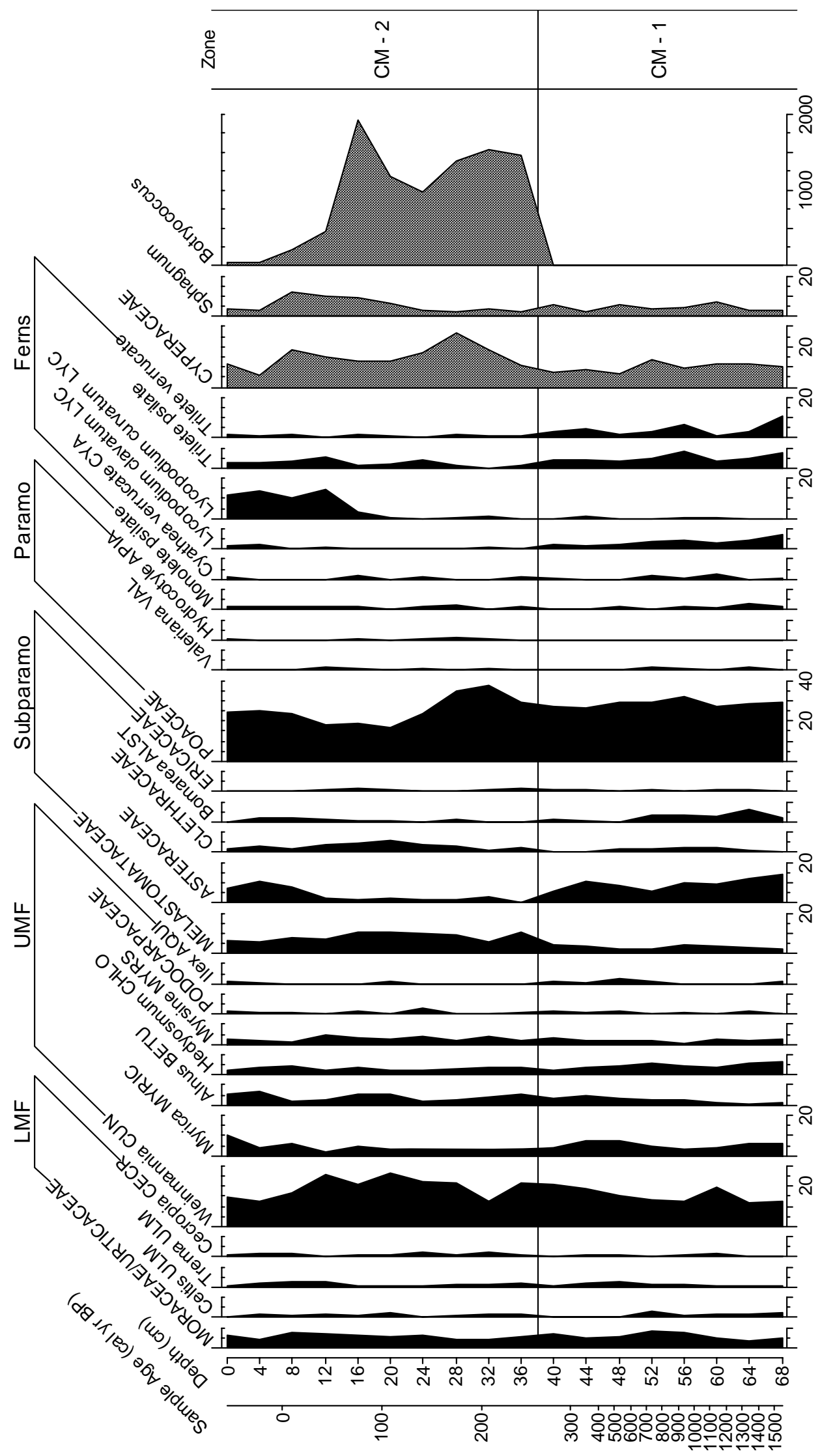

Figure 5.5: Pollen percentage diagram of the sediment core from Cocha Caranga mire (2710 m) showing the sample ages (cal yr BP), selected pollen and spore taxa grouped into lower mountain forest (LMF), upper mountain forest (UMF), subparamo, and paramo and the pollen zones. 


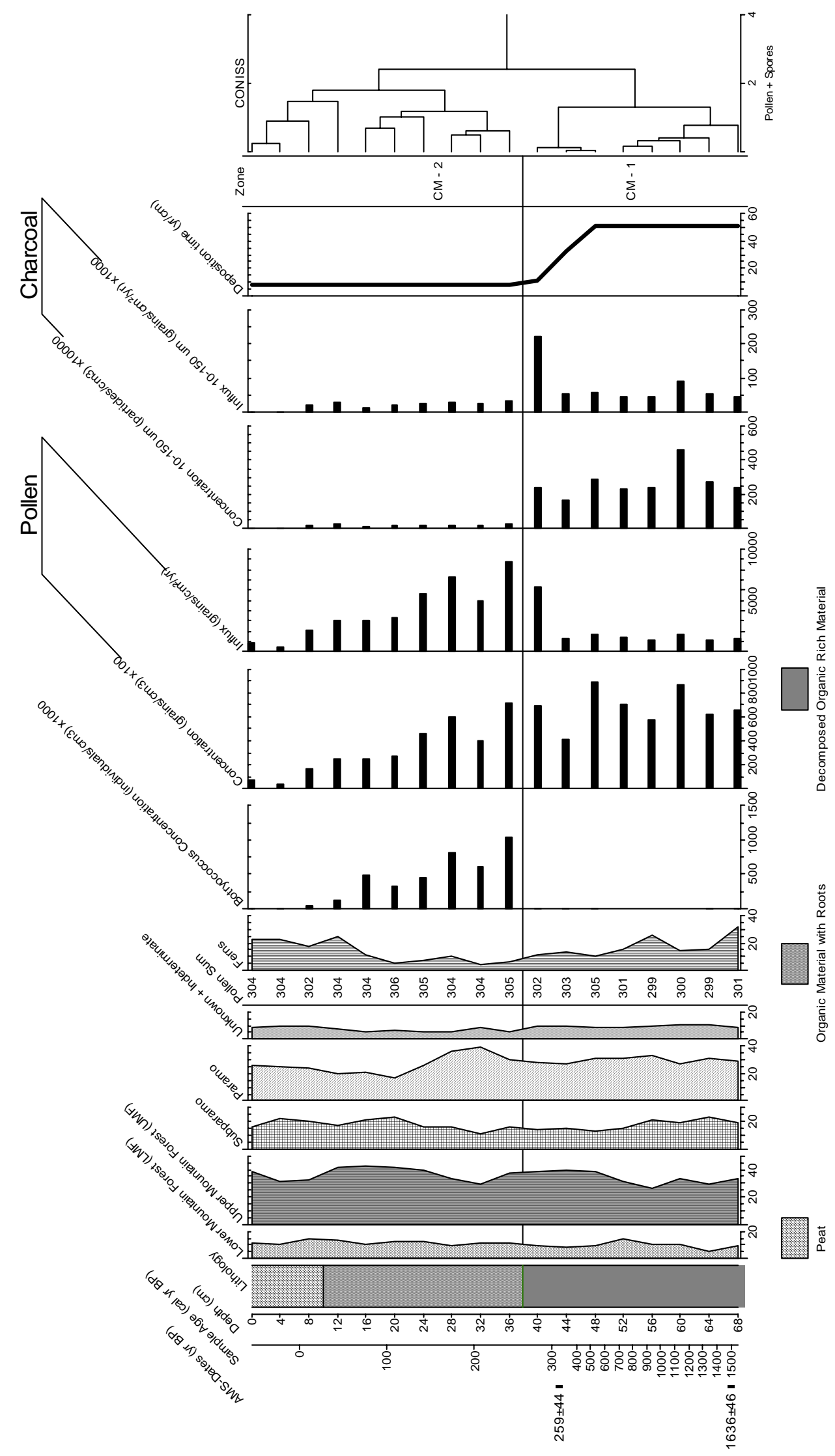

Figure 5.6: Pollen summary diagram of the sediment core from Cocha Caranga mire $(2710 \mathrm{~m})$ showing showing the AMS radiocarbon dates, sample ages (cal yr BP), the lithology, sums of ecological groups, the pollen sum, the deposition time, algae, pollen and charcoal concentration, pollen and charcoal influx, the pollen zones and the CONISS dendrogram. 


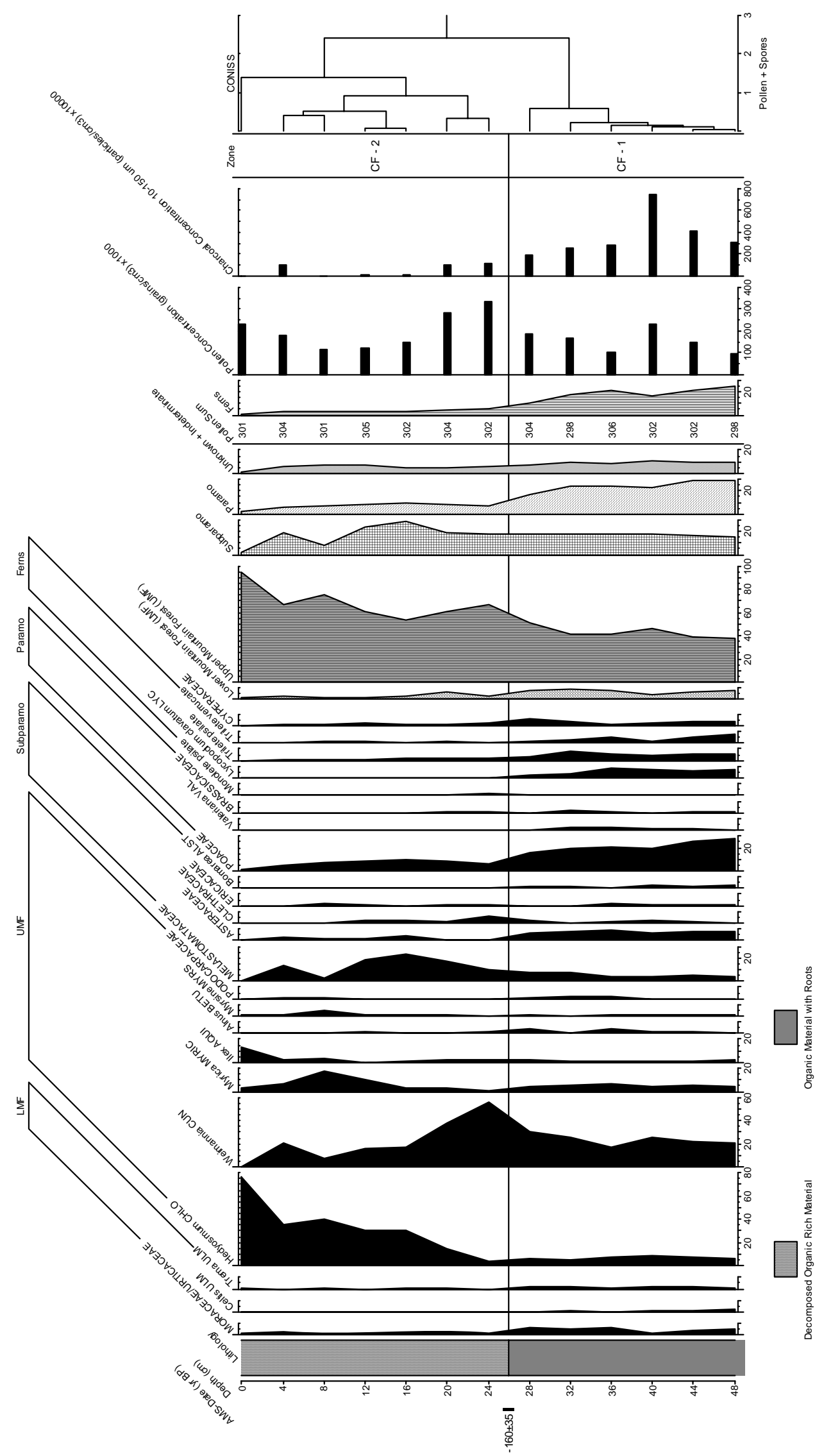

Figure 5.7: Pollen percentage and sumary diagram of the soil core from Cocha Caranga forest (2700 m) showing the lithology, selected pollen and spore taxa grouped into lower mountain forest (LMF), upper mountain forest (UMF), subparamo, and paramo, sums of ecological groups, the pollen sum, pollen and charcoal concentration, the pollen zones and the CONISS dendrogram. 
$\left(0.5-2.5\right.$ million individuals $\left./ \mathrm{cm}^{3}\right)$ is highest, pollen concentration $\left(<500,000\right.$ grains $\left./ \mathrm{cm}^{3}\right)$ is low and charcoal concentration (1.8-6.5 million particles $\left./ \mathrm{cm}^{3}\right)$ is very high in this zone. Pollen influx (1000-2500 grains $\left./ \mathrm{cm}^{2} / \mathrm{yr}\right)$ is low and charcoal influx $\left(7000-30,000\right.$ particles $\left./ \mathrm{cm}^{2} / \mathrm{yr}\right)$ is high.

Zone CL-4 (37-22.5 cm, ca. 4200-1300 cal yr BP, 8 subsamples) show an increase of pollen taxa originated from mountain forest. Weinmannia rises (from 9 to $25 \%$ ) in the uppermost part of this zone. Myrica (6-28\%) reach highest amounts during this period. Moraceae/Urticaceae (3-6\%), Hedyosmum, Myrsine, Alnus and Podocarpaceae (all 2-5\%) are well represented. Subparamo taxa, especially Melastomataceae (3-6\%) are rare. Poaceae strongly decrease from 40 to $15 \%$. Pollen of Cyperaceae (25-68\%) show highest amounts in this zone. Isoetes $(2-9 \%)$ is low represented. Fern spores $(8-27 \%)$ show lower amounts as the preceding zone. Botryococcus concentration $\left(0.05-1\right.$ million individuals $\left./ \mathrm{cm}^{3}\right)$ decrease, pollen concentration $\left(<500,000\right.$ grains $\left./ \mathrm{cm}^{3}\right)$ is low and charcoal concentration (1.2-5 million particles $\left./ \mathrm{cm}^{3}\right)$ is very high. Pollen influx $\left(1000-2500\right.$ grains $\left./ \mathrm{cm}^{2} / \mathrm{yr}\right)$ is low and charcoal influx (9000-25,000 particles $\left./ \mathrm{cm}^{2} / \mathrm{yr}\right)$ is high during this period.

Zone CL-5 (22.5-0 cm, ca. 1300 cal yr BP to modern times, 12 subsamples) is marked by an increase of subparamo taxa, especially Melastomataceae (7-17\%), Clethra (3-6\%) and Asteraceae (2-5\%). Pollen taxa originated from mountain forest, especially Weinmannia (2030\%), Alnus (3-10\%), Moraceae/Urticaceae (6-8\%), Hedyosmum (1-7\%), Myrica and Myrsine (both 3-6\%) show relatively stable values. Poaceae (12-20\%) are well represented. Pollen of Cyperaceae (5-25\%) decreases and Sphagnum spores (3-10\%) show highest amounts in this zone. Isoetes is nearly absent now. Fern spores (3-10\%) show low amounts. Botryococcus concentration $\left(250,000-900,000\right.$ individuals $\left./ \mathrm{cm}^{3}\right)$ is high, pollen concentration $(<100,000$ grains $\left./ \mathrm{cm}^{3}\right)$ and charcoal concentration $\left(<300,000\right.$ particles $\left./ \mathrm{cm}^{3}\right)$ is lowest during this period. Pollen influx (ca. 1000 grains $/ \mathrm{cm}^{2} / \mathrm{yr}$ ) and charcoal influx (ca. 5000 particles $/ \mathrm{cm}^{2} / \mathrm{yr}$ ) is low.

\section{Description of the pollen diagram of Cocha Caranga mire (CM) (Figs. 5.5 and 5.6)}

Zone CM-1 (68-33 cm, ca. 1550-260 cal yr BP, 10 subsamples) show a relatively stable representation of mountain forest and (sub)-paramo taxa. Weinmannia (12-15\%), Asteraceae (5-10\%), Melastomataceae, Moraceae/Urticaceae, Myrica (all 4-8\%), Hedyosmum (5-7\%), Alnus (1-5\%) and Bomarea (0-5\%) are well represented. Poaceae (28-33\%) show high values in this zone. Cyperaceae (8-12\%) and Sphagnum spores (3-6\%) show low amounts. Fern spores decreases from 32 to $8 \%$. Botryococcus is nearly absent. Pollen concentration $(40,000-$ 90,000 grains $\left./ \mathrm{cm}^{3}\right)$ and charcoal concentration $\left(2-4.8\right.$ million particles $\left./ \mathrm{cm}^{3}\right)$ is highest during this period. Pollen influx (600-6000 grains $\left./ \mathrm{cm}^{2} / \mathrm{yr}\right)$ is lowest and charcoal influx $(50,000$ $\left.220,000 \mathrm{particles} / \mathrm{cm}^{2} / \mathrm{yr}\right)$ is relatively high.

Zone CM-2 (33-0 cm, ca. 260 cal yr BP to modern times, 8 subsamples) is marked by relatively stable representation of mountain forest and subparamo taxa. Weinmannia (1225\%), Melastomataceae (7-10\%), Moraceae/Urticaceae (5-8\%), Myrica (4-10\%), Asteraceae (1-10\%), Hedyosmum, Alnus (both 3-6\%), Clethra and Myrsine (both 2-5\%) show high values. Poaceae (20-38\%) is high represented. Pollen of Cyperaceae (7-25\%) and Sphagnum spores (4-12\%) show highest amounts. Fern spores are well represented, especially spores of Lycopodium curvatum increases (up to $15 \%$ ) in the uppermost part of this zone. Botryococcus concentration $\left(<10,000-1.2\right.$ million individuals $\left./ \mathrm{cm}^{3}\right)$ and pollen concentration $(5000-60,000$ grains $\left./ \mathrm{cm}^{3}\right)$ strongly decrease and charcoal concentration $\left(<30,000\right.$ particles $\left./ \mathrm{cm}^{3}\right)$ is lowest during this period. Pollen influx (1000-9000 grains $\left./ \mathrm{cm}^{2} / \mathrm{yr}\right)$ decrease and charcoal influx $\left(<30,000\right.$ particles $\left./ \mathrm{cm}^{2} / \mathrm{yr}\right)$ is low. 


\section{Description of the pollen diagram of Cocha Coranga forest (CF) (Fig. 5.7)}

Zone CF-1 (26-48 cm, 6 subsamples) show increasing values of pollen taxa originated from UMF, Weinmannia rise from 20 to $35 \%$. Other mountain forest and subparamo taxa, mainly Hedyosmum (7-10\%), Melastomataceae, Asteraceae (both 5-10\%), Myrica (3-7\%) and Moraceae/Urticaceae (3-6\%) are relatively rare during this period. Poaceae (12-26\%) show high amounts. Fern spores (8-25\%) show highest values in this zone. Pollen concentration is relatively high $\left(100,000-250,000\right.$ grains $\left./ \mathrm{cm}^{3}\right)$ and charcoal concentration (2-7.5 million particles $/ \mathrm{cm}^{3}$ ) is highest during this period.

Zone CF-2 (26-0 cm, 7 subsamples) is marked by an increase of pollen taxa originated from UMF. Hedyosmum strongly rise from 8 to $80 \%$, Weinmannia strongly decrease from nearly 55 to 1\%. Myrica (5-28\%), Ilex (1-13\%) and Myrsine (1-7\%) are relatively frequent during this period, as well as subparamo taxa of Melastomataceae (5-20\%), Clethra $(1-7 \%)$ and Asteraceae (1-5\%). Poaceae (4-10\%), as well as fern spores (1-13\%) show lowest values in this zone. Pollen concentration is high $\left(100,000-350,000\right.$ grains $\left./ \mathrm{cm}^{3}\right)$ and charcoal concentration $\left(<0.01-1.2\right.$ million particles $\left./ \mathrm{cm}^{3}\right)$ is relatively low during this period.

\subsection{Interpretation and discussion}

\section{Late Pleistocene and Holocene vegetation and climate development}

Palaeoenvironmental changes were investigated from three pollen, spore, algae and charcoal records, cored in a small circle from less than $100 \mathrm{~m}$, at the Cocha Caranga area. The ca. 65 $\mathrm{cm}$ long sediment core from Laguna Cocha Caranga at $2710 \mathrm{~m}$ elevation (Figs. 5.3 and 5.4) shows an extrapolated core age of ca. 14,500 cal yr BP, indicating late Pleistocene and Holocene deposits. The age probably reflects the beginning of sediment accumulation at Laguna Cocha Caranga. High percentages of Isoetes indicate that the small basin was filled with shallow water. The reason for the establishment of the lake may be a result of a local landslide. A remnant of the glacier period can be excluded. Glaciation in the Podocarpus National Park region stops at ca. 2750-2800 m (Rozsypal 2000). At the El Tiro-Pass (2810 $\mathrm{m})$, the bottom of the sediment core shows an age of ca. 20,100 cal yr BP, indicating early deglaciation or a missing of glaciers (Niemann and Behling 2008c).

During the late Pleistocene to early Holocene period (Zone CL-1, ca. 14,500-9700 cal yr BP) taxa from upper mountain forest, mainly Weinmannia strongly increases, reflecting a raise in temperature and a shift of vegetation zones, as well as the tree line into higher elevation. The strong decrease of Isoetes indicates a lake level rise, coupled with higher precipitation at Laguna Cocha Caranga. At the El Tiro-Pass $(2810 \mathrm{~m})$, ca. $10 \mathrm{~km}$ northwest of the core site, mountain forest taxa, as well as ferns becomes frequent, reflecting higher temperatures and moisture (Niemann and Behling 2008c). Fossil pollen data from the central Peruvian Andes $(4000 \mathrm{~m})$ point to increasing moisture, as well as higher temperatures from about 12,910 to $7850 \mathrm{cal}$ yr BP (Hansen et al. 1994). The pollen record of Lake Surucucho in the Las Cajas National Park $(3200 \mathrm{~m})$ indicates an establishment of mountain rainforest vegetation by an increase of Weinmannia and Hedyosmum at ca. 12,260 cal yr BP (Colinvaux et al. 1997). At Laguna Chochos (3285 m), eastern Peruvian Andes, a warm and wet early Holocene from ca. 11.500 to $9500 \mathrm{cal} \mathrm{yr} \mathrm{BP}$ was estimated (Bush et al. 2005).

The period from early to mid Holocene (Zone CL-2, ca. 9700-6900 cal yr BP) is characterised by a reduction of arboreal taxa, Weinmannia and Melastomataceae decreases, coupled with an expansion of Poaceae and ferns, reflecting a response of the vegetation on a marked increase of fires. At the El Tiro-Pass $(2810 \mathrm{~m})$, fires increase at ca. $7500 \mathrm{cal} \mathrm{yr} \mathrm{BP}$ (Niemann and Behling 2008c). At Laguna Chochos $(3285 \mathrm{~m}$ ) fires were rare until ca. 11,500 cal yr BP (Bush et al. 2005). The pollen records from upper Rio San Francisco valley (ca. 
2000-3200 m), ca. $15 \mathrm{~km}$ northwest of the core site, show a highly sensitive reaction of Weinmannia and Melastomataceae on increasing and decreasing fires (Niemann and Behling 2008b).

Cyperaceae, an indicator for marshy lake shores and Isoetes, an indicator for shallow water, show are common, reflecting a low water level during this period. The missing roots in the sediment indicate that a minimum water body probably remained; the low concentration of the green algae Botryococcus supports this. Botryococcus braunii usually thrives in freshwater bogs, temporary pools, ponds, and lakes in which it may form a thick surface scum (Batten and Grenfell 1996). Palynomorph studies from Itapeva Lake, southeastern Brazil show a marked decrease of algae (e.g. Botryococcus) and higher amounts of Cyperaceae and Poaceae probably indicating the lowering of the water column and reduction in the size of the water body (Bohns-Meyer 2005). High percentages of lake shore vegetation (e.g. Cyperaceae) indicate low water depth at Tulare Lake, California. Relative to the littoral indicators, the colonial green algae Botryococcus is used as an indicator of open water at the coring site (Davis 1999).

The early to mid Holocene period from ca. 9700 to $6900 \mathrm{cal} \mathrm{yr} \mathrm{BP}$ is interpreted as a drier period (Fig. 5.8). High values of Cyperaceae and Isoetes coupled with low concentration of Botryococcus reflecting a lower lake level, caused by reduced precipitation. XRF data from Laguna Rabadilla de Vaca $(3312 \mathrm{~m})$, ca. $25 \mathrm{~km}$ southwest of the core site, indicate a drier period lasting from ca. 8990 to $6380 \mathrm{cal} \mathrm{yr} \mathrm{BP} \mathrm{(Niemann} \mathrm{et} \mathrm{al.} \mathrm{2007).} \mathrm{At} \mathrm{the} \mathrm{El} \mathrm{Tiro-Pass}$ $(2810 \mathrm{~m})$ an upper mountain rainforest established during the late early to mid Holocene period from ca. 8900 to 3300 cal yr BP, reflecting warmer climatic conditions (Niemann and Behling 2008c). At Laguna Chochos $(3285 \mathrm{~m})$ a warm and wet early Holocene was interrupted by a warm-dry event that lasted from ca. 9500 to 7300 cal yr BP (Bush et al. 2005). The pollen record from Laguna Loma Linda (310 m), Colombian savannah, shows a significantly lower and seasonality stronger precipitation than today during the period from ca. 9650 to 6850 cal yr BP (Behling and Hooghiemstra 2000). Data from Colombian Cauca Valley $(1020 \mathrm{~m})$ indicates a dry maximum at ca. 8300 cal yr BP, when dry forest reached maximum expansion (Berrio et al. 2002).

During the mid Holocene (Zone CL-3, ca. 6900-4200 cal yr BP) upper mountain forest vegetation expands little and Poaceae decreases, as a reaction of little lower fire intensity during this period. The mid Holocene period from ca. 6900 to $4200 \mathrm{cal} \mathrm{yr} \mathrm{BP}$ is interpreted as a wetter period (Fig. 5.8). An increase of ferns and the high concentration of Botryococcus coupled with low values of Cyperaceae and Isoetes indicates a higher lake level, caused by higher precipitation. The raised concentration of Botryococcus suggests an enlarging of the water body; the marshy lake shores are flooded now. XRF data from Laguna Rabadilla de Vaca $(3312 \mathrm{~m})$ indicate a warm and wetter period between ca. 6380 to 3680 cal yr BP (Niemann et al. 2007). At Laguna Loma Linda $(310 \mathrm{~m})$ the rainforest taxa increased markedly during the period from ca. 6850 to $3900 \mathrm{cal}$ yr BP, reflecting higher precipitation (Behling and Hooghiemstra 2000). The pollen record Yasuni National Park (220 m), Ecuadorian Amazonia, shows wet climatic conditions from ca. 5800-4900 cal yr BP (Weng et al. 2002).

During the mid to late Holocene period (Zone CL-4, ca. 4200-1300 cal yr BP) upper mountain forest vegetation, especially Myrica, expands. The strongly increase of Myrica may be a result of human influence (discussed later). The mid to late Holocene period from ca. 4200 to 1300 cal yr BP is interpreted as a drier period (Fig. 5.8). The decrease of ferns and the lower concentration of Botryococcus coupled with a strongly increase of Cyperaceae indicates a lake level down, due to a reduction in precipitation. The water body declines, marshy lake shores occur now. At Laguna Rabadilla de Vaca (3312 m), a Poaceae dominated herb-paramo occurred from ca. 3680 cal yr BP until modern times, reflecting cooler climatic conditions relative to the mid Holocene period. XRF- and charcoal data indicates a decline in precipitation after ca. 3680 cal yr BP (Niemann et al. 2007). At Lake Aricota (2800 m), in the 
central Peruvian Andes, maximum Holocene lake level was attained before ca. $2800 \mathrm{cal} \mathrm{yr}$ BP. Moderately high lake levels occurred at ca. 1600 and ca. 1230 cal yr BP (Placzek and Quade 2001). In opposite to a moister late Holocene, the pollen record from Laguna Loma Linda $(310 \mathrm{~m})$ shows a continued increase of rainforest taxa from ca. 3900-2300 cal yr BP, precipitation was still increasing and the length of the annual dry period possibly shortened (Behling and Hooghiemstra 2000). At the Yasuni National Park (220 m), wetter climatic conditions occurs from ca. 3700-1000 cal yr BP (Weng et al. 2002).

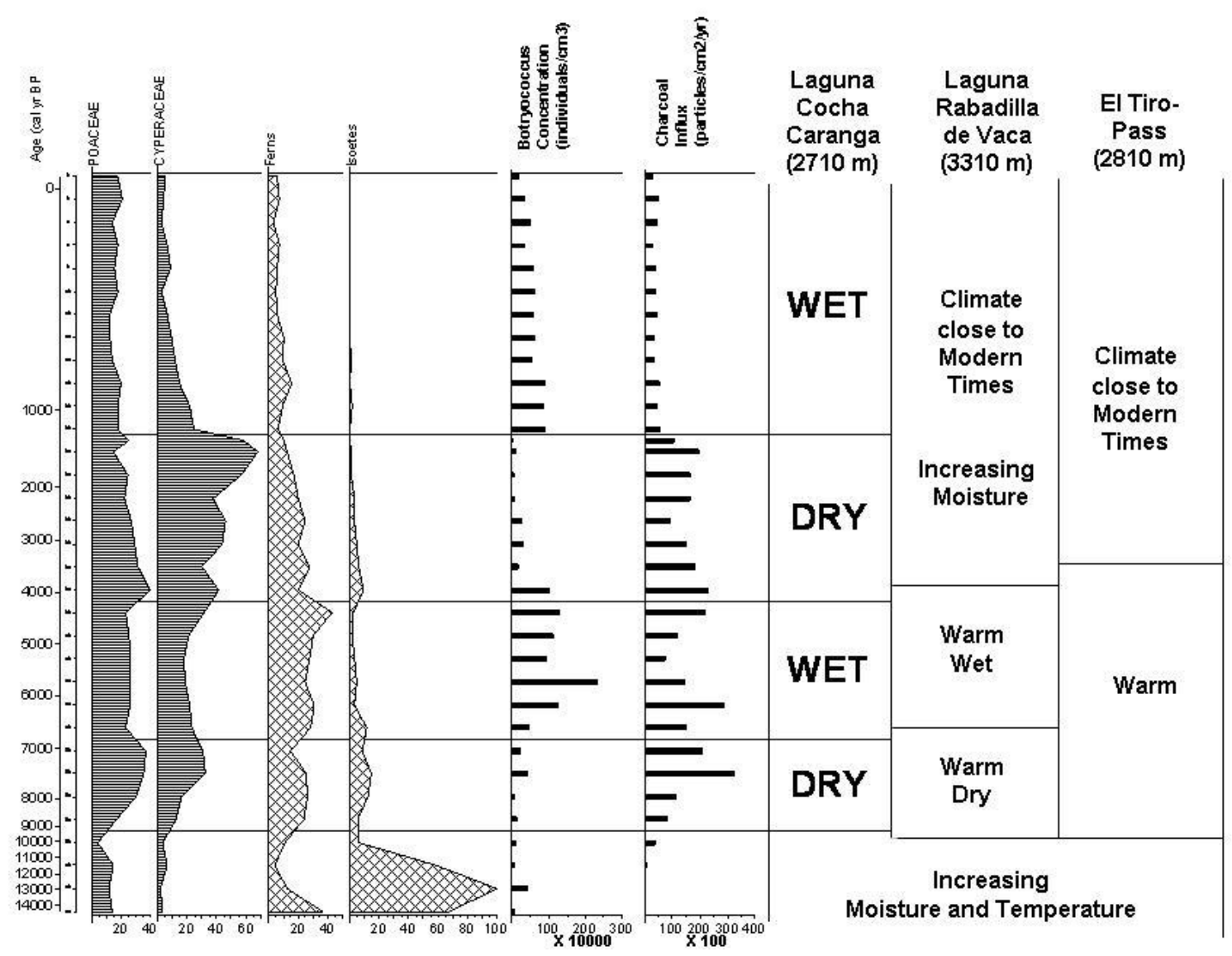

Figure 5.8: Holocene wet/dry phases of Laguna Cocha Caranga in comparison with other core sites from Podocarpus National Park region.

During the late Holocene period (Zone CL-5, ca. 1300 cal yr BP to recent) the vegetation is characterised by open grassy areas with forest patches and peat bogs established around Laguna Cocha Caranga. Weinmannia, Melastomataceae, Moraceae/Urticaceae, Myrsine and Clethra became more frequent. Myrica and Poaceae decreases, probably as a result of the lower fire intensity. This may indicate a reduction of human activity as well as wetter climatic conditions. Alnus also increases during this period, also reflecting wetter climatic conditions. Alnus occurs particularly on marshy grounds, covers large wetland areas, grows along river beds and follows landslides as a pioneer (Marchant et al. 2002). In the upper Rio San Francisco valley (ca. 2000-3200 m) the forest starts to regenerate after the decrease of fire intensity from between ca. 970 to $400 \mathrm{cal}$ yr BP, initiated by a succession of Weinmannia and Melastomataceae (Niemann and Behling 2008b).

The late Holocene period from ca. $1300 \mathrm{cal}$ yr BP to recent is interpreted as a wetter period (Fig. 5.8), modern vegetation as well as modern climate become established. The occurrence of the moss Sphagnum, reflects the formation of a mire near the shore line of Laguna Cocha Caranga during this period. An abrupt increase of Botryococcus concentration and a strong 
decrease of Cyperaceae and Isoetes reflect a rapid flooding of marshy lake shores. Laguna Cocha Caranga reaches a lake level close to modern time ca. 1300 cal yr BP. Palaeoenviremental data from Laguna Zurita $(2590 \mathrm{~m})$ in the upper Rio San Francisco valley show a decrease of Isoetes and Cypreaceae, indicating a flooding of marshy lake shores between ca. 1350 and 790 cal yr BP. After ca. 790 cal yr BP the modern lake level was reached (Niemann and Behling 2008b). Pollen data from three old river channel lakes (Rio Napo, ca. $300 \mathrm{~m}$ ) in the western Amazon basin of Ecuador show regional flooding from ca. 700-1200 AD (Colinvaux et al. 1988a). Pollen data from the endorheic Lake Ayauch (500 m) in the Inter-Andean Plateau of Ecuador reveal local evidence for a moist episode from ca. 400 to $1200 \mathrm{AD}$ (Colinvaux et al. 1988b).

The late Pleistocene and Holocene climate development (Fig. 5.8) of Laguna Cocha Caranga, in general correspondents to the previous studies of the Podocarpus National Park region (Laguna Rabadilla de Vaca and El Tiro-Pass), as well as to other palaeoenviremental records of tropical South America (discussed above). Our data as well corresponds to studies from outside tropical South America. A Holocene thermal optimum inferred from subalpine pollen sequence of Taiwan, eastern Asia, shows a warmer interval occurring between ca. 8000 and $4000 \mathrm{cal} \mathrm{yr} \mathrm{BP,} \mathrm{when} \mathrm{the} \mathrm{subtropical} \mathrm{forests} \mathrm{were} \mathrm{most} \mathrm{extensive} \mathrm{(Liew} \mathrm{et} \mathrm{al.} \mathrm{2006).}$ A mid-Holocene thermal optimum, estimated from sediment records in the subpolar North Atlantic, lasted from ca. 8300 to $5750 \mathrm{cal} \mathrm{yr} \mathrm{BP}$ and is followed by cooler and more stable late Holocene climatic conditions (Andersen et al. 2004). A marine sediment core from the eastern South Atlantic was investigated at high temporal resolution for variations of seasurface temperature (SST). A warming trend associated with the deglaciation phase was followed by a cooling event with lowest SSTs near $20^{\circ} \mathrm{C}$, persisting for about 1000 years between ca. 13,000 and 12,000 cal yr BP. The SSTs then continued to increase to about $22.5^{\circ}$ $\mathrm{C}$ at ca. $7000 \mathrm{cal} \mathrm{yr} \mathrm{BP}$, and decreased again during the late Holocene to a core-top value of $19.8^{\circ} \mathrm{C}$ (Jung-Hyan et al. 2002). Optical dating has been used to obtain the ages of fossilstabilized sand dunes from four sections in the northeastern deserts of China. The Holocene warm climate optimum in this region is between ca. 10,000 and $3600 \mathrm{cal} \mathrm{yr} \mathrm{BP} \mathrm{(Kim} \mathrm{et} \mathrm{al.}$ 2002).

The $69 \mathrm{~cm}$ long sediment core of Cocha Caranga mire at $2710 \mathrm{~m}$ elevation (Figs. 5.5 and 5.6) represents late Holocene peat bog deposits with an extrapolated age of ca. 1550 cal yr BP.

The lower part of the record (Zone CM-1, ca. 1550-250 cal yr BP) in general shows no marked changes except higher occurrence (sub)-paramo taxa, especially Asteraceae and Bomarea, as well as ferns. The higher fire frequency may be responsible for that.

In the upper part of the record (Zone CM-2, ca. 250 cal yr BP to recent) Weinmannia, Melastomataceae and fern taxa are less frequent, probably in fact of the lower fire intensity. The abrupt increase of Botryococcus at ca. 250 cal yr BP suggests that the lake level raised, the mire becomes flooded now, probably episodic, during months with higher precipitation. However, it has to be considered that Botryococcus may be occurs in freshwater bogs; otherwise it is possible that Botryococcus is flushed into the mire due to the higher lake level. After this episode of ca. 200 years, corresponding to the end of "Little Ice Age", with a probably higher seasonal precipitation the modern lake level became established. During the late Holocene, stable isotopes in ice cores from Huascaran in the central Peruvian Andes (up to $6000 \mathrm{~m}$ elevation), indicate a warmer period from ca. 1140 to $1250 \mathrm{AD}$, possibly reflecting the "Medieval Warm Period" and a cooler period between ca. 1300 and 1850 AD, correlating with the "Little Ice Age" period of the northern hemisphere (Thompson et al. 2003).

The abrupt change of a few taxa at ca. 1300 cal yr BP, the increase of Botryococcus and Melastomataceae and decrease of fern taxa and fire intensity, in the record of Laguna Cocha Caranga is quite similar to the change of same taxa at ca. $250 \mathrm{cal}$ yr BP in the record of Cocha Caranga mire. A gap in the record of Laguna Cocha Caranga can not be excluded. It has to be 
considered, that palaeoenviremental changes in precipitation and/or temperature causes reaction of the ecosystem, a continuously sediment accumulation seems to be more relevant. However, the ordered radiocarbon date of the record from Cocha Caranga forest will be show the entirety of past vegetation development at the core localities under a new focus.

The $49 \mathrm{~cm}$ long soil core from Cocha Caranga forest at $2700 \mathrm{~m}$ elevation (Fig. 5.7) represents late Holocene deposits of a forest patch, the age is still unclear. The lower part of record (Zone CF-1) shows a higher occurrence of Poaceae and fern taxa. The higher fire frequency may be responsible for that. After the decrease of fires the forest patch started to expand (Zone CF-2), by a succession of Weinmannia, Melastomataceae, Hedyosmum and Myrica. Weinmannia reacts first and highly sensitive on varying fire intensity, also observed in the pollen record of Laguna Cocha Caranga, as well as in the records of the upper Rio San Francisco valley at ca. 2000-3200 m (Niemann and Behling 2008b) and the record of Laguna Rabadilla de Vaca at 3312 m (Niemann et al. 2007).

\section{Human impact}

The charcoal record of Laguna Cocha Caranga shows a marked increase of fire intensity during the period from ca. 9700 to 1300 cal yr BP. An abruptly decrease of arboreal taxa, coupled with high values of Poaceae and ferns taxa reflects the reaction of the vegetation of increasing fires. The charcoal record in comparison with wet/dry phases, illustrated in Figure 5.8, show nearly no reaction of higher or lower precipitation during this more than 8000 years long period. This suggests that human impact is probably responsible for the strong fires during this period. It is possible that fires at the slopes below Laguna Cocha Caranga originate from anthropogenic activities, probably caused by hunting activities in the savannah or dry forest areas of the close dry Loja basin. A marked increase of charcoal influx values may indicate the beginning of human influence at the El Tiro-Pass $(2810 \mathrm{~m})$ from about $7500 \mathrm{cal}$ yr BP (Niemann and Behling 2008c). In the Sabana de Bogota (Colombia) the presence of Amerindians could be established from ca. 14,800 cal yr BP onward and possibly even before that time (Van der Hammen 1978).

Between ca. 4800 and 1300 cal yr BP Myrica expands, may be indicating settling activities in the valleys below Laguna Cocha Caranga. Myrica occurs at degenerated areas and along trails, reflecting that this plant accompanies settling activities. Due to the mean grow height; Myrica is not common in closed forests (Homeier, personal communication). First human activity in the region of Loja, pointed out with ceramic fragments, has been dated by around $4000 \mathrm{yr}$ BP. Since then the native Palta culture established around Loja and Zamorra (Guffroy 2004). At the El Tiro-Pass (2810 m), fires increased markedly at ca. $3500 \mathrm{cal} \mathrm{yr} \mathrm{BP} \mathrm{(Niemann}$ and Behling 2008c).

The decrease of Myrica and Poaceae, coupled with an increase of e.g. Weinmannia and Melastomataceae, as well as the low fire intensity after ca. 1300 cal yr BP indicates a reduction of human activity around Laguna Cocha Caranga. The reduction of human activities may be a result of civil conflicts in pre Inca time, the resettling politics of the Inca and the arrival of the Spanish conquest. The pollen records from upper Rio San Francisco valley, about $15 \mathrm{~km}$ northwest of the core site, show a decrease of Poaceae and the crop taxa Zea mays, as well as an increases of forest taxa between ca. 970 to 400 cal yr BP. Coupled with a decrease of fire intensity, indicating a reduction of human activities (Niemann and Behling 2008b). Data from the Colombian Cauca Valley $(1020 \mathrm{~m})$ show a reduction of human activity after ca. $870 \mathrm{cal}$ yr BP. The expansion of secondary forest taxa may indicate depopulation and abandonment of previously cultivated land (Berrio et al. 2002). The pollen record from Lake Ayauch $(500 \mathrm{~m})$ shows Zea cultivation between ca. 2960 and ca. 720 cal yr BP. The abandonment of Zea cultivation may have been due social unrest (Bush and Colinvaux 1988). 
In the $8^{\text {th }}$ century, indigenous population came in war in the La Toma valley, about $10 \mathrm{~km}$ north of Loja (Guffroy 2006). In the middle of the $15^{\text {th }}$ century the Inca occupied Ecuador. They defeat the indigene chiefdom called Palta. It was the strategy of the Inca to settle defeated populations in other regions of their empire, this has happened with the Palta (Alvaredo 2002). After the almost 70-year rule (1463-1531 A.D) in southern Ecuador the Inca were defeated by the Spanish conquests (Pohle 2008). The Spanish occupants brought old world diseases to the new world, including Ecuador; this caused a decrease of the indigenous population (Alchon 1991).

\subsection{Summary and conclusions}

Studying the late Pleistocene and Holocene vegetation, climate and fire dynamics as well as human impact at Laguna Cocha Caranga, southeastern Ecuador, we addressed following main research questions:

(1) How developed vegetation during the past and is the grassy vegetation with forest patches natural or caused by humans? The late Pleistocene to early Holocene expansion of mountain rainforest vegetation stopped by increasing fires at ca. 9700 cal yr BP. During the following, more than 8000 years lasting period, open grassy vegetation occurs. The late Holocene development of forest patches probably depends on decreasing fire intensity. Due to the strong human activities, at the slopes below Laguna Cocha Caranga, a natural development seems to be improbable. In particular, at an elevation of ca. $2710 \mathrm{~m}$ a close forest ecosystem has to be considered.

(2) Could the pollen, spore, algae and charcoal records offer over-regional climatic signals, in comparison to other core sites? The identified lake level fluctuation were used to reconstruct Holocene wet/dry phases, corresponding to previous studies of the Podocarpus National Park region, as well as to other palaeoenviremental records of tropical South America.

(3) Played fires a role during the past and how strong was human impact? The high fire intensity from ca. 9700 to $1300 \mathrm{cal}$ yr BP highly influenced the past vegetation development and is interpreted as a period of strong human impact, due to a limited reaction of the charcoal record to the estimated wet/dry phases.

Acknowledgements: Corinna Brunschön and Fernando Rodriguez are thanked for accompanies the field work, as well as Felix Matt (research station leader) for his logistical support and for his information about the study region. The project FOR 402/D1 (Vegetation-, climate- and fire dynamics in the Podocarpus National Park region) is kindly funded by the Deutsche Forschungsgemeinschaft (DFG). 


\title{
6. Late Quaternary vegetation, climate and fire dynamics inferred from the El Tiro record in the southeastern Ecuadorian Andes
}

\author{
Journal of Quaternary Science (2008), 23(3): 203-212
}

\author{
Holger Niemann, Hermann Behling
}

Department of Palynology and Climate Dynamics, Albrecht-von-Haller-Institute for Plant Sciences, University of Göttingen, Untere Karspüle 2, 37073 Göttingen, Germany

\begin{abstract}
In order to study the stability and dynamics of mountain rainforest and paramo ecosystems including the biodiversity of these ecosystems, the Holocene and late Pleistocene climate and fire variability, and human impact in the southeastern Ecuadorian Andes we present a high resolution pollen record from El Tiro-Pass (2810 m elevation), Podocarpus National Park.

Palaeoenvironmental changes, investigated by pollen, spores and charcoal analysis, inferred from a $127 \mathrm{~cm}$ long core, spanning the last ca. 21,000 cal yr BP, indicate that grass-paramo was the main vegetation type at the El Tiro-Pass during the late Pleistocene period. The grassparamo was rich in Poaceae, Plantago rigida and Plantago australis, reflecting cold and moist climatic conditions. During the early Holocene from 11,200 to 8900 cal yr BP subparamo and upper mountain rainforest vegetation expanded slightly, this indicates a slow warming of climatic conditions during this period. From 8900 to $3300 \mathrm{cal} \mathrm{yr}$ BP an upper mountain rainforest developed at the study site, indicated by an increase of Hedyosmun, Podocarpaceae, Myrsine and Ilex. This suggests a warmer climate than present day at this elevation. The modern subparamo vegetation became established since $3300 \mathrm{cal}$ yr BP at the El Tiro-Pass. Fires, probably anthropogenic origin, were very rare during the late Pleistocene and became frequent after $8000 \mathrm{cal}$ yr BP.
\end{abstract}

Keywords: late Pleistocene, Holocene, palynology / pollen, Tropics, climate change, South America 


\subsection{Introduction}

In this paper, we discuss vegetation, climate and fire dynamics inferred from a fossil pollen and charcoal record from the southeastern Ecuadorian Andes with a special focus on landscape development and human impact. This study has been carried out in the framework of the "Deutsche Forschungsgemeinschaft" (DFG) research group "Tropical Mountain Ecosystems"

Despite the importance of understanding the landscape history, especially in hotspots of biodiversity, some pollen records are available from the Ecuadorian Andes (e.g. Bush et al. 1990; Colinvaux 1997; Hansen et al. 2003).

The pollen record from Lake Surucucho (Las Cajas Nationa Park, $3200 \mathrm{~m}$ ) at the eastern flank of the western Ecuadorian Andes show treeless vegetation in glacial times and Holocene development of modern Andean forests (Colinvaux 1997).

In northeastern Ecuador, records of the road cut sites at Mera (ca. 34,000-31,000 yr BP) and San Juan Bosco (31,000-26,000 yr BP), show a significant presence of mountain taxa such as Alnus and Podocarpus at low elevations of $1100 \mathrm{~m}$ and $970 \mathrm{~m}$, respectively, suggesting a cooling of ca. $7.5^{\circ} \mathrm{C}$ below present during the middle of the last glacial period (Bush et al. 1990).

In southwestern Ecuador in Las Cajas National Park in the western Cordillera $(3700 \mathrm{~m}$ elevation), studies indicate for the late-glacial period (17,000-11,000 cal yr BP) a herb paramo, reflecting colder and moister climatic conditions, relative to these of today. Fires were rare at that time. The beginning of the Holocene is marked with the expansion of moist mountain forest. During the Holocene Polylepis became more frequent and reached its maximum during the mid-Holocene period. Fires were much more frequent during the early and mid-Holocene than during the late-glacial period. After 4000 cal yr BP vegetation changes and the decrease of charcoal particles suggest a change to moister conditions (Hansen et al. 2003).

Other palynological studies, from a similar landscape, are available from the eastern Andes of northern Peru (Hansen et al. 1994; Hansen and Rodbell 1995; Berrio et al. 2002; Bush et al. 2005), from the eastern Andes of southern Colombia (Hooghiemstra and Van der Hammen 1993; Wille et al. 2001; Velez et al. 2006) and from the eastern Andes of Venezuela (Rull et al. 2005).

The pollen record from Laguna Baja in northern Peru (3575 m elevation) indicates a marked vegetation and timberline oscillation during the late-glacial period. A warm and moist climate was responsible for an open mixed mountain forest at ca. 12,000 yr BP (13,970 cal yr BP) in northern Peru. This was followed by the expansion of paramo at the expense of the mixed mountain forest, suggesting a cooler and/or more arid interval between ca. 11,600 and 10,000 yr BP $(13,478$ and 11,480 cal yr BP). During the Holocene, both temperature and precipitation increased, resulting in the replacement of paramo vegetation with wet mountain forest. The record from Laguna Baja also suggests a drier climate between ca. 9000 and 6000 yr BP (10,200 and 6830 cal yr BP) (Hansen and Rodbell 1995).

At Laguna Chochos (3285 m), in the eastern Andes of northern Peru, the late glacial period was cool and moist, and the vegetation was sparse on the glacial forelands. A warm and wet early Holocene was interrupted by a dry event that lasted from ca. 9500 to $7300 \mathrm{cal} \mathrm{yr}$ BP (Bush et al. 2005).

The Fuquene Lake record, on the Eastern Andean Cordillera of Columbia (2580 m), records dry and cold condition is found during the late Pleistocene between 19,700 and 14,200 yr BP $(23,350-17,030 \mathrm{cal}$ yr BP). A return to dry conditions is indicated by a hiatus between 13,110 and 8680 yr BP (15,600-9560 cal yr BP). Very humid conditions prevailed during the early mid-Holocene, from 8680 to $7070 \mathrm{yr}$ BP (9560-7870 cal yr BP), the lake reached its maximum extend during that period. A dry mid-late Holocene period is reflected by a 
decreasing lake level between 7070 to $4300 \mathrm{yr}$ BP (7870 to 4900 cal yr BP). Minimum lake levels were reached between 3700 and $1550 \mathrm{yr}$ BP (4230-1770 cal yr BP). From $1550 \mathrm{yr}$ BP (1770 cal yr BP) to present the lake was relatively shallow (Velez et al. 2006).

The pollen record from Laguna Verde Alta at the eastern Andean Cordillera of Venezuela $(4215 \mathrm{~m})$, remained a periglacial desert, practically not vegetated between 15,500 and 11,000 cal yr BP. Since about 11,000 cal yr BP a Lycopodiaceae assemblage (for example $c f$. Huperzia) bearing no modern analogue colonized the superparamo. Although this community persisted until about $6000 \mathrm{cal} \mathrm{yr} \mathrm{BP}$, it began to decline somewhat earlier, in synchrony with cooling following the Holocene thermal maximum of the Northern Hemisphere. At this time, the pioneer assemblage was replaced by a low-diversity superparamo community that became established $9000 \mathrm{cal}$ yr BP. This replacement coincides with regional declines in temperature and/or available moisture. Modern, more diverse superparamo assemblages were not established until about $4600 \mathrm{cal}$ yr BP, and were accompanied by a dramatic decline in Alnus (Rull et al. 2005).

During the LGM most Andean glaciers moved down slope, reaching lowermost positions from about $3000 \mathrm{~m}$ in the eastern Andes of Colombia, Ecuador and northern Peru (Clapperton 1993; Rodbell 1992, 1994).

Glaciers in Ecuadorian Andes advanced before 12,500 yr BP and between 10,500 and 9000 yr BP. Rapid climatic fluctuations during the last deglaciation are documented by glacier advances, but they are not synchronous with the European events (Heine and Heine 1996).

The early and middle Holocene periods were marked by a widespread recession of glaciers in most parts of the Andes, but a return to cooler and more humid conditions apparently occurred after about $5000 \mathrm{yr}$ BP. The present-day equilibrium snowline in the eastern Ecuadorian Andes is at near $4800 \mathrm{~m}$ and glaciers terminate at $4400 \mathrm{~m}$ elevation. The moraine frontier of the last glaciations is found between 2800 and $3350 \mathrm{~m}$ elevations (Clapperton 1993).

Similar time periods for major changes, have been identified in the Amazon lowland, by the expansion of Amazon rainforest north and south of the equator (Behling and Hooghiemstra 2000, 2001; Mayle et al. 2000).

Glacier reconstruction at Cerro Chirripo, Costa Rica, indicated that deglaciation occurred some time after 12,360 cal yr BP and before 9600 cal yr BP (Orvis and Horn 2000).

Two ice cores from Huascaran in north-central Andes of Peru contain glacial stage conditions at high elevation $(6048 \mathrm{~m})$ from as much as $8{ }^{\circ} \mathrm{C}$ to $12{ }^{\circ} \mathrm{C}$ cooler than today. The climate was the warmest from 8400 to $5200 \mathrm{yr}$ BP (9455 to 5960 cal yr BP) (Thompson et al. 1995).

Very cold climatic conditions prevailed during LGM, with temperatures suggested being at least $5^{\circ} \mathrm{C}$ to $8^{\circ} \mathrm{C}$ cooler than present (Paduano et al. 2003).

In a regional study the depression of mean annual temperature in the southern tropical Andes glaciated alpine areas was ca. $5.4 \pm 0.8^{\circ} \mathrm{C}$ during the last glaciation (Porter 2001).

\subsection{Site description}

\section{Location}

The Andes are a mountain chain, with peaks up to an altitude of more than $6000 \mathrm{~m}$. The Andes of southern Ecuador and northern Peru include the so-called Andean depression (Depresion de Giron-Cuenca in Ecuador and Huancabamba in Peru). The main peaks of the mountains in this region only reach up to about $4000 \mathrm{~m}$. Active volcanoes are absent. The study area is part of the western slope of the eastern Cordillera in the southern Ecuadorian Andes, east of Loja in the inter-Andean valley. 

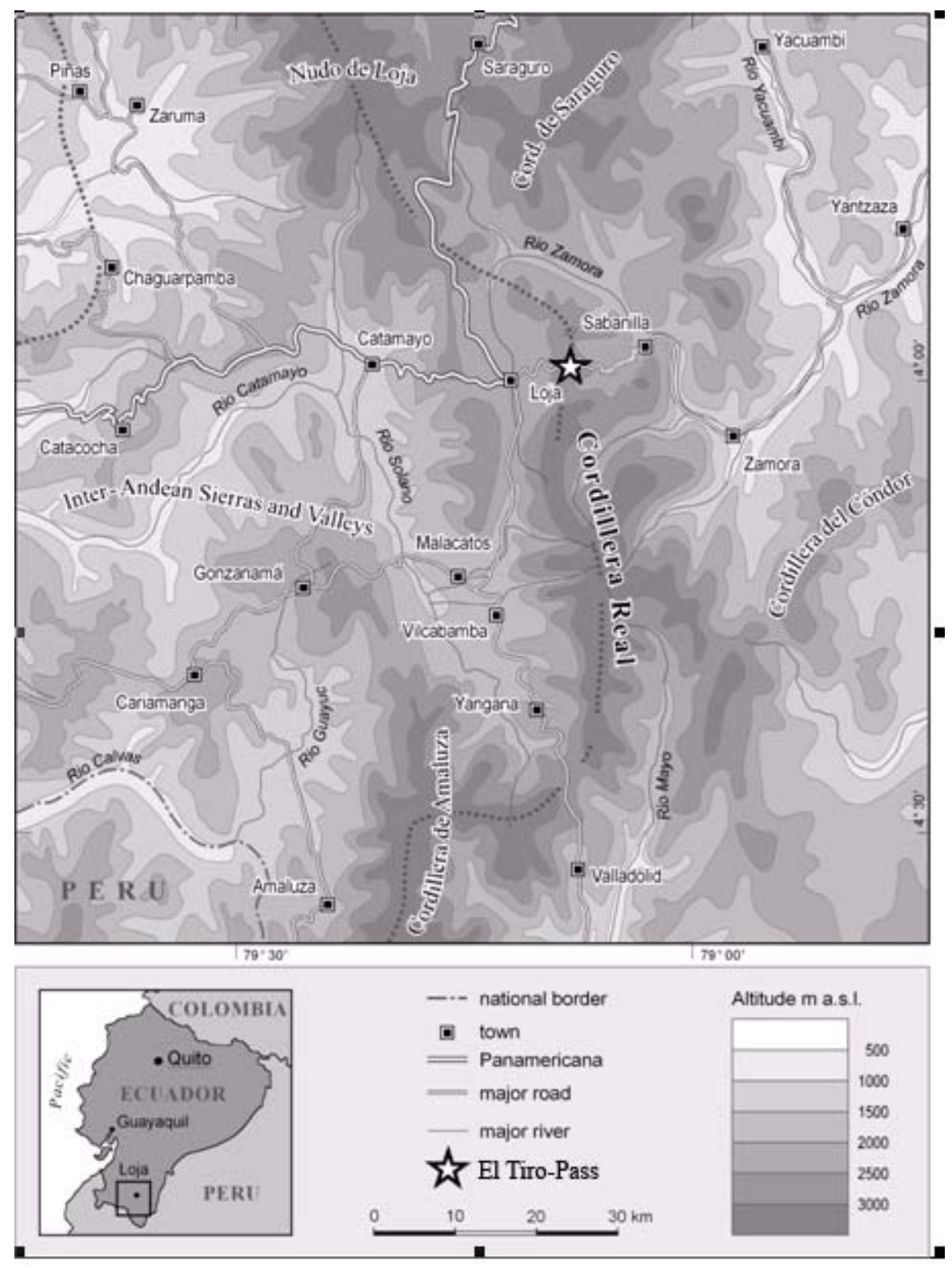

Figure 6.1: Map of Ecuador, showing the location of El Tiro-Pass in southeastern Ecuador near Loja (modified after Richter 2003).

The El Tiro-Pass is located at $2810 \mathrm{~m}$ elevation in the eastern Cordillera, north of the Podocarpus National Park, adjacent to the main road from Loja to Zamorra (Fig. 6.1). The El Tiro-Pass is about $10 \mathrm{~km}$ from Loja. The small bog at the El Tiro-Pass (Coordinates: S $\left.03^{\circ} 50^{\prime} 25.9^{\prime \prime}, \mathrm{W} 79^{\circ} 08^{\prime} 43.2^{\prime \prime}\right)$ is about $800 \mathrm{~m}$ from the summit, which has an elevation of about $3200 \mathrm{~m}$. The $1.3 \mathrm{~m}$ deep bog is located in a small depression about $30 \mathrm{~m}$ wide and $60 \mathrm{~m}$ long.

\section{Modern vegetation}

The different vegetation types in the study area are mainly related to altitudinal gradients. The lower mountain rainforest is found at an elevation between 1800 and $2150 \mathrm{~m}$ with an extremely diverse, 2- storied tree stratum and is composed of a numerous 20-35 $\mathrm{m}$ tall tree species. Undisturbed communities of this type can be found particularly on steep slopes with $30-50^{\circ}$ inclination, as well as up to elevations of $2300 \mathrm{~m}$ at the bottom of wind-protected 
riverine valleys. Characteristic species are e.g. Alzetea verticillata (Alzataceae), Graffenrieda miconioides (Melastomataceae) and Myrcianthes sp. (Myrtaceae) (Bussmann 2001; Lozano et al. 2003).

The upper mountain rainforest is found at elevations between 2100 and $2800 \mathrm{~m}$. This forest is being replaced by a much lower, monotypic formation, with only one tree stratum between 5-10 m, rarely up to $15 \mathrm{~m}$ tall. Characteristic trees are Purdiaea nutans (Cyrillaceae), Myrica pubescens (Myricaceae) and Myrsine andina (Myrsinaceae) (Bussmann 2001).

The subparamo is present at altitudes between 2800 and $3100 \mathrm{~m}$, characterised by Puya nitida (Bromeliaceae), Brachyotum rotundifolium (Melastomataceae) and Oritrophium peruvianum (Asteraceae). The shrubs and herbs grow up to 1 (Individual shrub species 2-3) $\mathrm{m}$ height (Lozano et al. 2003).

The paramo is found at elevations from 3100 to $3400 \mathrm{~m}$ and is characterised by species such as Arcytophyllum setosum (Rubiaceae), Blechnum cordatum (Blechnaceae), Puya maculate (Bromeliaceae) and Gynoxis buxifolia (Asteraceae) (Lozano et al. 2003).

The modern timber line in the Loja region is at about $3200 \mathrm{~m}$. This is about $800 \mathrm{~m}$ lower than in the central and the northern Ecuadorian Andes, probably as a result of the so-called Andean depression (Richter and Moreira-Munoz 2005). The high human activity (periodic burning often was observed) in the Loja region may influence the elevation of the timber line.

\section{Climate}

The climate in the southeastern Ecuadorian Andes is influenced by warm moisture-laden air from the Amazon lowland, which collides with cold mountain air masses. This produces much of the rainfall in the eastern Andean mountains. The high rainfall rates establish the mountain rainforest to the east and west of the Cordillera. The climate of the paramo/subparamo is the humid tropical diurnal type with cold nights and cool days. There is a short drier period lasting from December until March (Bosman et al. 1994). As part of the Andean depression, all summits in the southern Ecuadorian Andes are below the snowline.

The eastern Andean mountains form a divide that separates the moist eastern slopes of the Andes from the dry inner-Andean basins (For example the Loja- and Catamayo Basin). Between the eastern slopes of the eastern Cordillera and the dry valley of Catamayo, which are only $70 \mathrm{~km}$ apart, annual rainfall rates drop from over $4000 \mathrm{~mm}$ to $300 \mathrm{~mm}$ (Bendix et al. 2004). The average precipitation rate (in the years 2003-2005) near the El Tiro-Pass (2880 m) is about $3500 \mathrm{~mm} / \mathrm{a}$ (Emck 2007).

\subsection{Methods}

The peat deposit at the El Tiro-Pass was cored using a Russian corer. The total length of the core is $127 \mathrm{~cm}$. Sections of $50 \mathrm{~cm}$ length were extruded on-site with split PVC tubes, wrapped with plastic film and stored under dark and cold $\left(+4{ }^{\circ} \mathrm{C}\right)$ conditions before processing.

5 subsamples (organic material and charcoal fragments) were taken for Accelerator Mass Spectrometer (AMS) radiocarbon dating from the El Tiro core. Radiocarbon ages have been calibrated with CalPal (Cal Curve $50 \mathrm{ka}$ cal BP to modern) (Weninger et al. 2004).

For pollen and charcoal analysis 64 subsamples $\left(0.25 \mathrm{~cm}^{3}\right)$ were taken at $2 \mathrm{~cm}$ intervals along the sediment core. All samples were processed with standard analytical methods (Faegri and Iverson 1989). Exotic Lycopodium spores were added to each sample before treatment for calculation of pollen concentration and accumulation rates. 300 pollen grains were counted for each sample. The pollen sum includes trees, shrubs and herbs and excludes fern spores and aquatic pollen taxa. Pollen identification relied on the reference collection from the second author with about 3000 neotropical species and literature (Behling 1993; Hooghiemstra 1984) and on a reference collection collected during the fieldwork. The ecological grouping of the 
identified pollen taxa into lower and upper mountain rainforest, subparamo and paramo has been carried out according to available data in the literature (Bussmann 2001; Lozano et al. 2003; Homeier and Werner 2005; Richter and Moreira-Munoz 2005). Pollen and spore data are presented in pollen diagrams as percentages of the pollen sum. Carbonized particles (2$150 \mu \mathrm{m}$ ) were counted on pollen slides and presented as influx (particles $/ \mathrm{cm}^{2} / \mathrm{yr}$ ). Larger carbonized particles $(250-700 \mu \mathrm{m})$ were observed, but not counted, from $73 \mathrm{~cm}$ up to the top of the record. The software TILIA, TILIAGRAPH and CONISS were used for illustration of the pollen and spore data (Grimm 1987). In total, 90 pollen and spore types were recognised. The pollen diagram (Fig. 6.3) shows records of the most abundant pollen and spore taxa. Figure 6.4 illustrates records of the ecological groups, pollen concentration and the pollen influx as well as the charcoal influx.

\subsection{Results}

\section{Stratigraphy}

The $127 \mathrm{~cm}$ long sediment core from the El Tiro-Pass consists of organic material with roots (0-7 cm depth), decomposed organic rich material $(7-49 \mathrm{~cm})$ and well decomposed organic rich material with silt and clay $(49-74 \mathrm{~cm})$. In the transition zone $(74-83 \mathrm{~cm})$ the organic matter content decreases. The lowermost part of the core consists of silty clay $(83-127 \mathrm{~cm})$. A detailed description of stratigraphic changes is as followed:

0-7 cm dark brown decomposed organic material with fine roots,

$7-49 \mathrm{~cm} \quad$ brown decomposed organic rich material,

49-74 cm light brown strongly decomposed organic rich material with some silt and clay,

$74-83 \mathrm{~cm}$ light brown to grey organic material with increasing amounts of silt and clay, $83-127 \mathrm{~cm}$ light grey silty clay.

\section{Chronology and pollen zonation}

Five AMS radiocarbon dates (Table 6.1) provide a detailed chronological control of the sediment core of El Tiro-Pass. The AMS date near the base of the core at $127 \mathrm{~cm}$ depth documents that the bog contains deposits which cover the last 20,100 cal yr BP.

\begin{tabular}{llccc}
\hline Lab. code & Dated material & Core depth $\mathbf{( c m )}$ & 14C yr BP & cal yr BP \\
& & & \\
\hline Erl-8371 & Leaf & 31 & $1828 \pm 55$ & $1767 \pm 63$ \\
Erl-8899 & Organic material & 48 & $2972 \pm 43$ & $3155 \pm 70$ \\
Erl-8898 & Organic material & 77 & $7850 \pm 71$ & $8713 \pm 131$ \\
Erl-9454 & Organic material & 97 & $11187 \pm 104$ & $13082 \pm 139$ \\
Erl-8372 & Organic material & 126 & $16517 \pm 128$ & $19836 \pm 306$ \\
\hline
\end{tabular}

Table 6.1: AMS-Radiocarbon 14C dates and calibrated ages for sediment core from El Tiro-Pass.

The series of five AMS dates shows a regular down-core increase of age, which indicates that sediments accumulated continuously. Cluster analysis of terrestrial pollen taxa produces a dendrogram that permits zonation of the record into the zones ET-1 to ET-7 (Fig. 6.4).

The average sedimentation rate of the El Tiro-Pass sediment core is shown in Figure 6.2. The sediment accumulation rate is relatively constant (average about $0.08 \mathrm{~mm} / \mathrm{yr}$ ). 


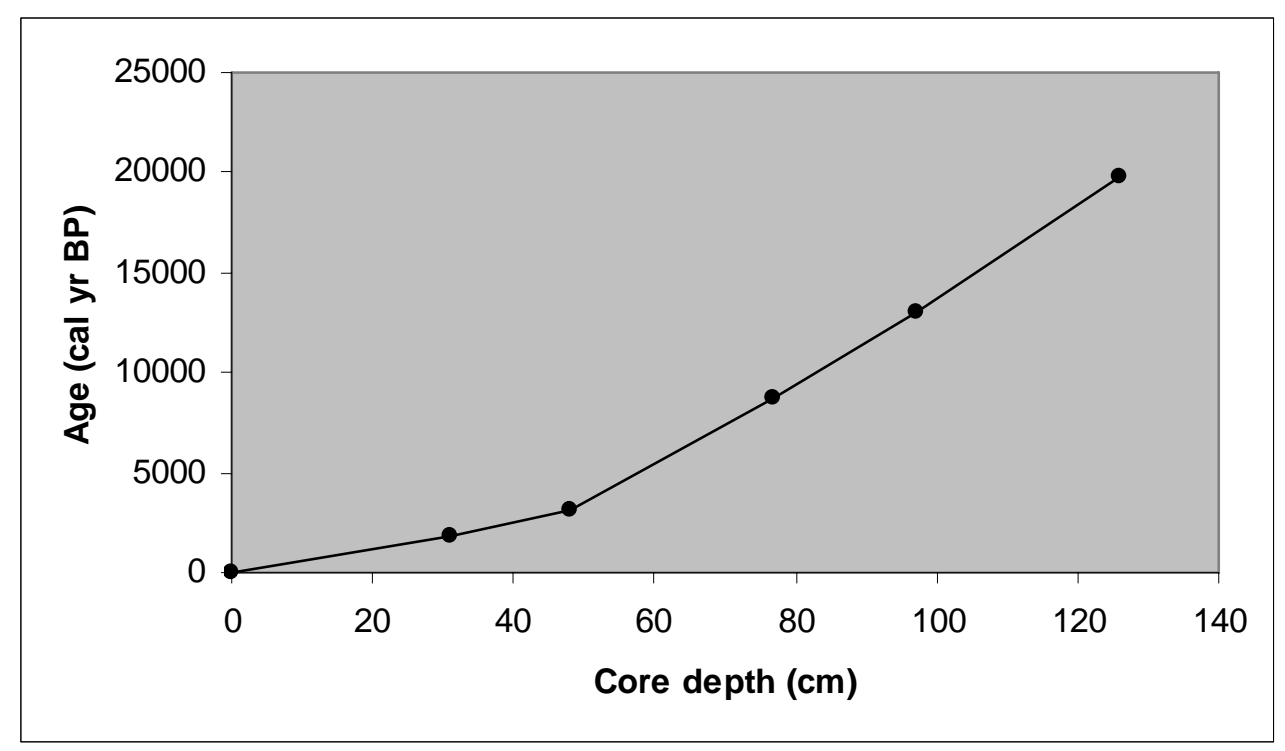

Figure 6.2: Average sedimentation rate of El Tiro-Pass sediment core (yr BP / core depth in cm).

\section{Description of the pollen diagram (Figs. 6.3 and 6.4)}

Zone ET-1 (126-108 cm, ca. 20,100-15,800 cal yr BP) is marked by a high representation of paramo herb pollen (65-85\%), primarily Poaceae (40-50\%), Plantago rigida and $P$. australis $(10-15 \%)$, rare Valeriana (2-5\%) and spores of Huperzia (5\%). Spores of Isoetes comprise $15-90 \%$. Taxa of subparamo and upper mountain rainforest total 15-25\%, primarily represented by Melastomataceae and Weinmannia. The charcoal influx was very low, less than 2500 particles $/ \mathrm{cm}^{2} / \mathrm{cal} \mathrm{yr}$.

Zone ET-2 (108-88 cm, ca. 15,800-11,200 cal yr BP) is characterised by a high number of paramo herb pollen (75-85\%), primarily Poaceae (35-45\%), increasing Plantago rigida and Plantago australis (20-30\%) and minor Valeriana (4-7\%). Fern spores of Huperzia decrease little (3-5\%). Spores of Isoetes decrease from 20 to $0 \%$. Taxa of subparamo and upper mountain rainforest total $10-18 \%$, primarily represented by Melastomataceae and Weinmannia (both 5-10\%). The charcoal influx values remain low.

Zone ET-3 (88-78 cm, ca. 11,200-8900 cal yr BP) is characterised by a strong decrease of paramo herb pollen (65-30\%). Taxa of subparamo and upper mountain rainforest increase to $25-45 \%$, primarily represented by Melastomataceae (10-20\%), Weinmannia (10-12\%), Podocarpaceae and Hedyosmum (both 5-8\%). Fern spores increase markedly from $10 \%$ up to $35 \%$, especially Cyathea (5-8\%) and Hymenophyllum (3-5\%). The lowest charcoal influx rates occur in this zone, less than 2000 particles $/ \mathrm{cm}^{2} / \mathrm{cal} \mathrm{yr}$.

Zone ET-4 (78-64 cm, ca. 8900-6200 cal yr BP) is also marked by a continuous decrease of pollen of paramo herbs (30-15\%). Taxa of subparamo and upper mountain rainforest increase strongly (45-75\%), represented by Melastomataceae (15-25\%), Weinmannia (10-15\%), Hedyosmum (5-15\%), Myrsine (3-10\%) and Ilex (3-8\%) as well as Clusia, Symplocos and Podocarpaceae. Taxa of lower mountain rainforest are represented in low amounts, Moaceae/Urticaceae (5-8\%), Alchornea and Arecaceae (0-2\%). Fern spores decrease markedly from $35 \%$ to $10 \%$. Charcoal influx increased from less than 2000 up to 10,000 particles $/ \mathrm{cm}^{2} / \mathrm{cal}$ yr.

Zone ET-5 (64-48 cm, ca. 6200-3300 cal yr BP) is characterised by high amounts of pollen from subparamo and upper mountain rainforest taxa (60-75\%), represented by Melastomataceae (25-35\%), Weinmannia (10-12\%), Hedyosmum (5-8\%), Podocarpaceae (5- 


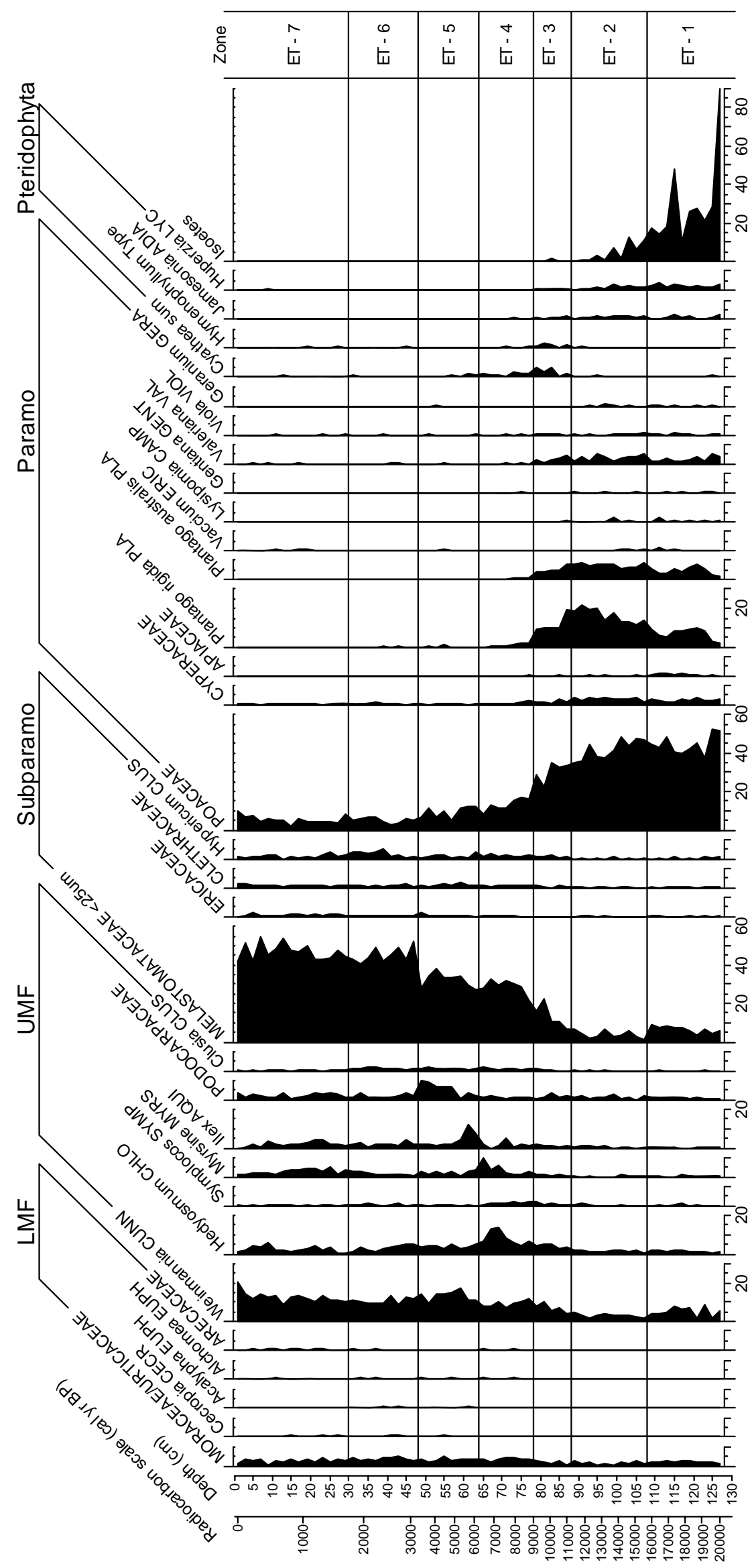

Figure 6.3: Pollen percentage diagram of core El Tiro-Pass ( $2810 \mathrm{~m}$ elevation) showing selected fossil pollen and spores taxa grouped into lower mountain rainforest (LMF), upper mountain rainforest (UMF), subparamo, paramo and Pteriodophyta. 


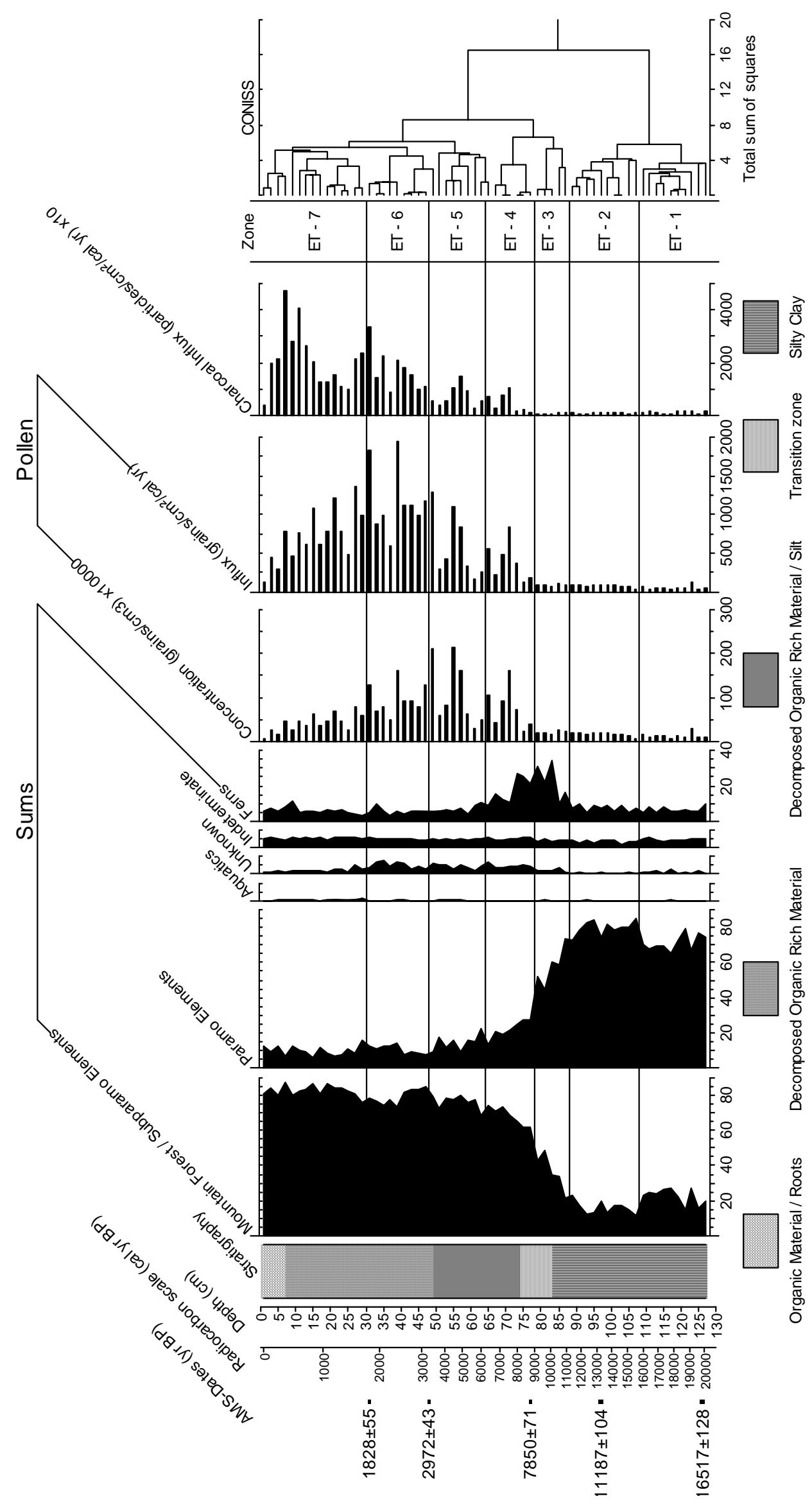

Figure 6.4: Pollen percentage diagram of core El Tiro-Pass (2810 m elevation) showing, radiocarbon dates, sums of ecological groups, records of pollen concentration, pollen influx, charcoal influx and the CONISS dendrogram. 
10\%), Myrsine (3-8\%), Ilex (3-12\%) and Symplocos (2-3\%). Lower mountain rainforest elements are rare, Moaceae/Urticaceae (5-8\%) and Alchornea (0-2\%). Herb taxa total 12$20 \%$, fern spores $(8-15 \%)$. The charcoal influx varies from 5000 to $15,000 \mathrm{particles} / \mathrm{cm}^{2} / \mathrm{cal}$ yr.

Zone ET-6 (48-30 cm, ca. 3300-1700 cal yr BP) is marked by a high representation of pollen from upper mountain rainforest and subparamo taxa (70-80\%), mainly Melastomataceae (40-50\%), Weinmannia (10-15\%), Hedyosmum (5-7\%), Podocarpaceae, Myrsine, Ilex and Symplocos (0-6\%). Taxa of lower mountain rainforest are represented in low amounts, Moaceae/Urticaceae (5-8\%), Alchornea and Arecaceae (0-2\%). Herb taxa total $12-20 \%$, fern spores $(8-10 \%)$. This zone is characterised by a high charcoal influx rate from 10,000-23,000 particles $/ \mathrm{cm}^{2} / \mathrm{cal} \mathrm{yr}$, with a maximum at ca. 1700 cal yr BP $(35,000$ particles $/ \mathrm{cm}^{2} / \mathrm{cal} \mathrm{yr}$ ).

Zone ET-7 (30-0 cm, ca. $1700 \mathrm{cal}$ yr BP to present) shows the highest percentages of upper mountain rainforest and subparamo taxa (75-85\%), represented by Melastomataceae (4050\%), Weinmannia (10-20\%), Hedyosmum, Podocarpaceae, Myrsine and Ilex (all with 3-5\%) Taxa of lower mountain rainforest are represented in low amounts, Moaceae/Urticaceae (5$8 \%)$, Alchornea and Arecaceae (0-2\%). Herb taxa total $12-20 \%$, fern spores $(8-12 \%)$. The highest charcoal influx rate is represented in this zone $10,000-30,000$ particles $/ \mathrm{cm}^{2} / \mathrm{cal} \mathrm{yr}$. A maximum is found at ca. $600 \mathrm{cal} \mathrm{yr} \mathrm{BP}\left(45,000 \mathrm{particles} / \mathrm{cm}^{2} / \mathrm{cal} \mathrm{yr}\right)$, there after influx rates decrease to 5000 particles $/ \mathrm{cm}^{2} / \mathrm{cal}$ yr at the core top.

\subsection{Past vegetation, climatic and fire dynamics}

During the late Pleistocene since ca. 20,100 cal yr BP (Zone ET-1 and ET-2) the pollen spectra document a landscape, dominated by grass-paramo, rich in Poaceae and Plantago. The most identified Plantago pollen is $P$. rigida and $P$. australis. Pteridophyta spores and spores of Huperzia are relatively rare. High percentages of Isoetes indicate that the small basin was filled with shallow water before the mire started to develop. The occurrence of paramo vegetation at this elevation indicates cold and the high frequency of Plantago rigida suggest wetter conditions. Fires were apparently absent or very rare during the Pleistocene.

Only a small increase of tree and shrub pollen is recorded during the early Holocene from ca. 11,200 to 8900 cal yr BP (Zone ET-3). Subparamo expanded slightly, and different ferns including tree ferns (Cyathea) became frequent. These changes indicate a moderate change to warmer and wetter conditions during this period. Fires were still very rare during this early Holocene period.

During the early-mid Holocene from ca. 8900-3300 cal yr BP (Zone ET-4 and ET-5), the upper mountain rainforest was predominant where today subparamo vegetation exists. A succession of Hedyosmum, Podocarpaceae, Myrsine, Ilex and the relatively low occurrence of Melastomatace compared to present-day reflect the formation of the upper mountain rainforest at the coring site. A marked increase of charcoal influx values may indicate the beginning of human influence in the region at about $8000 \mathrm{cal} \mathrm{yr} \mathrm{BP.}$

During the late Holocene period, since ca. 3300 cal yr BP (Zone ET-6 and ET-7) upper mountain rainforest vegetation decreased and the modern subparamo vegetation with a high occurrence of Melastomataceae became established and were relatively stable. This vegetation change reflects a change to wetter and probably also cooler conditions than during the early-mid Holocene. Charcoal concentration increase and show two main peaks at ca. 1700 and $600 \mathrm{cal}$ yr BP before decreasing significantly after $500 \mathrm{cal} \mathrm{yr}$ BP. The increase of fire frequency even during this wetter period probably indicates that fires were man made. Different fire intensities may also suggest changes in human activity. 


\subsection{Discussion}

The pollen record indicates that the El Tiro-Pass, which is today naturally covered with subparamo, was covered with grass-paramo during the recorded Pleistocene period since 20,100 cal yr BP. Plantago australis and the cushion plant Plantago rigida were frequent during the late Pleistocene, especially during the period from 15,800-11,200 cal yr BP. In particular Plantago rigida reflect cold and wet, rather than dry conditions. According to Cleef (1978) Plantago rigida constitutes cushion bogs at high elevation (3000-5200 m elevation) in the puna and paramo. They are common in the grass-paramo (ca. 3600-4200 m elevation) of the Colombian Andes and occur in boggy valleys, on former lakes or even float on glacial lakes in the humid bamboo-paramo. Plantago australis is common taxa in wet subparamo and wet grass-paramo vegetation. In the eastern cordillera of Colombia this subspecies was recorded with low cover in different azonal moist paramo communities (Cleef 1978). The pollen data from Holocene mire in the Chingaza National Park at $3730 \mathrm{~m}$ elevation, in the eastern Cordillera of middle Colombia in the grass-paramo zone, show a high occurrence of Plantago rigida pollen. Cushions of Plantago rigida dates from the early Holocene $9000 \mathrm{yr}$ BP (10,200 cal yr BP) until today and experienced several periods of expansion and reexpansion. The expansion of the Plantago rigida cushion took place under cool and humid conditions. Under warmer and drier conditions the expansion stopped (Bosman et al. 1994). At Laguna Chochos $(3285 \mathrm{~m})$, in the eastern Andes of northern Peru, the low pollen influx and charcoal values indicate that the initial deglacial conditions were markedly cooler than today with low to moderate precipitation, and that there was not enough vegetation biomass to sustain fire (Bush et al. 2005).

Huperzia became less frequent at the end of the Pleistocene. This is also documented in the pollen record of Laguna Chorrereas at an elevation of $3700 \mathrm{~m}$ (Las Cajas National Park, western Cordillera). There, Huperzia sp. spores decrease during the transition from the late Pleistocene-Holocene period. Huperzia sp. and Lycopodium sp. characterize the upper cold wet paramo (Hansen et al. 2003).

Fires were rare during the late Pleistocene in the El Tiro region. This has been also found in the record from Lake Surucucho in the Las Cajas National Park (Colinvaux et al. 1997). At Laguna Chochos fires were rare until 11,500 cal yr BP (Bush et al. 2005).

A relatively low increase of mountain rainforest and subparamo shrubs and trees is observed during the early Holocene period from 11,200-8900 cal yr BP, suggests that the formation of forest vegetation in the upper Andean regions was slow and took a long period of about 2300 years. This might be due to a slow increase in temperature and a slow retreat of the glaciers in the northern Andes. Results from fossil pollen records from the central Peruvian Andes (4000 $\mathrm{m})$ point to increased moisture as well as higher temperatures from about 11,000 to $7000 \mathrm{yr}$ BP $(12,910$ to 7850 cal yr BP) (Hansen et al. 1994). At Cerro Chirripo, Costa Rica (about $3500 \mathrm{~m}$ ) deglaciation occurred some time after 12,360 cal yr BP and before 9600 cal yr BP (Orvis and Horn 2000). The dates from pollen record of Lake Surucucho (3200 m) indicate a much earlier establishment of mountain rainforest and subparamo by an increase of Weinmannia and Hedyosmum at 10,300 yr BP (12,260 cal yr BP) (Colinvaux 1997).

Fern spores including tree ferns (Cyathea) expanded markedly, reflecting a change to more humid conditions at the study site during this early Holocene period. The record from Laguna Baja also shows an increase of fern spores between ca. 12,000 and 11,000 yr BP (13,970 and 12,910 cal yr BP), (Hansen and Rodbell 1995).

During the later early-mid Holocene period from ca. 8900-3300 cal yr BP a succession of Hedyosmun, Podocarpaceae, Myrsine and Ilex may indicate the formation of the upper mountain rainforest at the study site. It is quite possible that upper mountain rainforest vegetation reflects a warmer climate, as indicated by the stronger decomposed organic material during this period. At the Fuquene Lake on the Eastern Andean Cordillera of 
Colombia $(2580 \mathrm{~m})$, very humid conditions are suggested during the early Mid-Holocene from 8680 to 7070 yr BP (9560-7870 cal yr BP) (Velez et al. 2006). From 8850 yr BP (10,010 cal yr BP) the record from La Teta, Cauca Valley in central Colombia (1020 m) indicates dry climatic conditions relative to present, these prevailing up to $2880 \mathrm{yr}$ BP (3010 cal yr BP) (Berrio et al. 2002).

According to Homeier and Werner (2005) elevational distribution data (taken about $10 \mathrm{~km}$ to the east of El Tiro-Pass at the Estacion Cientifica San Francisco (ECSF), next to Sabanilla) indicate the following taxa elevation relationships: Hedyosmum 1800-2600 m, Podocarpaceae 1800-2700 m, Myrsine 1900-3100 m and Ilex 1800-3100 m. However, this suggestion has to be examined in detail when other additional records are available from the southeastern Ecuadorian Andes. Melastomataceae is the most dominant family in the subparamo today (Lozano et al. 2003; Richter, personal communication). During the early-mid Holocene period, Melastomataceae pollen was recorded about 15\% lower than during the late Holocene. This suggests also the formation of the upper mountain rainforest rather than subparamo at the coring site.

Fern spores decreases during the period of 8900-6200 cal yr BP (Zone ET-4) while the charcoal influx increase markedly, indicating that fires became quite frequent during this period. Macroscopic charcoal has been observed from $73 \mathrm{~cm}$ (ca. $8000 \mathrm{cal} \mathrm{yr} \mathrm{BP)} \mathrm{up} \mathrm{to} \mathrm{the}$ top of the record. This may suggest that fires occurred near the El Tiro-Pass on the slopes of the El Tiro mountain and may have reduced the frequency of different fern species in the vegetation. So far, it is difficult to determine whether fires were of natural or anthropogenic origin. The first human activity in the region of Loja is dated at around 4500 cal yr BP (Guffroy 2004), but human activities may have occurred in the dry Inter-Andean valley much earlier. For example, in the Sabana de Bogota (Colombia) the presence of Amerindians could be established from 12,500 yr BP $(14,800$ cal yr BP) onward and possibly even before that time (Van der Hammen and Urrego 1978). It is somewhat speculative, but it is possible that fires on the El Tiro mountains slopes originate from anthropogenic fires by hunting activities in the savanna or dry forest area of dry Loja basin after 8000 cal yr BP.

During the mid-late Holocene period since 3300 cal yr BP, the pollen data suggest by the increase of Melastomataceae the formation of relatively stable subparamo vegetation at the study site. Fires remained frequent during the mid Holocene period and increased during late Holocene in the El Tiro region. The increased fire intensity during the wetter late Holocene strongly suggests that frequent fires were of anthropogenic origin. We assume that by the increased use of fire for hunting proposes and by slash and burning activities in the drier lower valleys (e.g. in the Loja area), fires spread into the mountains during drier phases of the year. The pollen record from Lake Surucucho in Las Cajas National Park $(3200 \mathrm{~m})$ also shows a strong increase of fires during the late Holocene (Colinvaux 1997). Fire frequency decreased during the last ca. 600 years. The reduction or the absence of human activities in the study region during the last centuries might be related to the dramatic decrease in the human population between 14th and 17th century. The decrease probably reflects the Inka invasion northwards and the following occupation of the Loja-region by the Inka. Another reason of the decreased population was probably the old world diseases, which the Spanish occupants brought to Ecuador (Alchon 1991). With the analysis of additional cores form the lower regions we want to verify this hypothesis.

\subsection{Conclusions}

(1) The El Tiro-Pass bog core at $2810 \mathrm{~m}$ elevation provides a detailed radiocarbon dated record of the late Pleistocene and Holocene environment dynamics close to the modern upper 
forest limit in the subparamo vegetation zone on the eastern Andean flank in southern Ecuador.

(2) During the recorded late Pleistocene period since ca. 20,100 cal yr BP grass-paramo, rich in Poaceae and Plantago rigida indicating cold and moist conditions.

(3) During the early Holocene from ca. 11,200-8900 cal yr BP subparamo and montain rainforest developed slightly in the upper region of the El-Tiro mountain, probably due to the relatively cold conditions.

(4) During the early-mid Holocene from ca. 8900-3300 cal yr BP the upper mountain rainforest was predominant, suggested by the less frequent occurrence of Melastomtaceae and the successional stages of Hedyosmun, Podocarpaceae, Myrsine and Ilex. The occurrence of the upper montain rainforest the coring site and the stronger decomposition of the organic material during that time suggest relatively warm and also somewhat drier conditions.

(5) During the late Holocene period since $3300 \mathrm{cal}$ yr BP the modern subparamo dominated by Melastomataceae became established, suggesting a somewhat cooler and wetter climatic condition than during the early-mid Holocene.

(6) Fires were rare during the late Pleistocene and became frequent only after 8000 cal yr BP. It is suggested that fires on the El Tiro mountain slopes originated from anthropogenic activities. During the last $500 \mathrm{cal}$ yr BP fire frequency decreased, probably due to the decrease of human population.

Acknowledgements: The project FOR 402/D1 is kindly funded by the Deutsche Forschungsgemeinschaft (DFG). Felix Matt (research station leader) is thanked for his logistical support and for his information about the Loja region. Thanks are also to Jürgen Homeier for using his species lists and his collected flower samples. 


\section{Supplementary studies}

\subsection{Sub recent pollen data in comparison with recent vegetation/modern pollen rain transect data on the altitudinal gradient from the Podocarpus National Park area (unpublished)}

Supplementary to recent vegetation/modern pollen rain relationship on an altitudinal gradient between 1800 and $3200 \mathrm{~m}$ in the ECSF research area (Chapter 2), the sub recent pollen input of seven cores from the Podocarpus National Park region (Tab. 1.1) was studied. For this study, the mean percentages of the three uppermost samples of each core sections were definite as sub recent pollen input. The tops from the cores ECSF-T2/250 $(1990 \mathrm{~m})$ in the LMF vegetation unit, ECSF-Refugio $(2520 \mathrm{~m})$, Laguna Zurita $(2590 \mathrm{~m})$ and Laguna Cocha Caranga $(2710 \mathrm{~m})$ in the UMF vegetation unit and El Tiro-Pass $(2810 \mathrm{~m})$, ECSF Cerro de Consuelo $(3155 \mathrm{~m})$ and Laguna Rabadilla de Vaca $(3310 \mathrm{~m})$ in the (sub)-paramo vegetation unit, were selected. Most abounded pollen taxa (reflecting more ore less than $90 \%$ of the identified pollen taxa each core section), as well as the sums of the ecological groups, were performed for this study. The software TILIA, TILIAGRAPH and CONISS were used to plot the data (Grimm 1987). The ecological grouping of the identified pollen taxa into LMF, UMF, subparamo and paramo follows available data in the literature (Homeier and Werner 2005; Lozano et al. 2003). Pollen and spore data are presented in the pollen diagram as percentages of the pollen sum (Fig. 7.1). The three uppermost samples represent an age range up to 340 cal yr BP, depending to the different ages of the cores.

This study indicates that the vegetation units of lower and upper mountain forest and (sub)paramo, according to recent vegetation/modern pollen rain study, are well reflected in sub recent pollen data. The dendrogram provided by CONISS verify this zonation. The results from sub recent pollen data on the altitudinal gradient show a high number of taxa corresponding to the altitudinal distribution of recent vegetation, as well as to modern pollen rain data.

The LMF pollen taxa of sub recent vegetation data show no evidence with genera and families of recent vegetation, but perfect evidence with modern pollen rain data. Moraceae/Urticaceae, Piper, Celtis, Acalypha and Alchornea occurs on the whole altitudinal gradient with lowest amounts in the LMF vegetation zone, wind dispersal may be responsible for that. This has been also observed in the modern pollen rain data. The UMF pollen taxa of sub recent vegetation show high evidence with genera and families of recent vegetation, as well as with the modern pollen rain data. The pollen taxa of sub recent vegetation of Purdiaea, Myrsine, Alnus, Myrica, Ilex, Myrtaceae, Styrax and Symplocos correspond to the altitudinal distribution of genera and families of recent vegetation. The pollen taxa of sub recent vegetation of Hedyosmum, Purdiaea, Myrsine, Clusia, Ilex, Myrtaceae, Styrax and Symplocos correspond to the altitudinal distribution of modern pollen rain taxa. (Sub)-paramo pollen taxa of sub recent vegetation show relatively high evidence with genera and families of recent vegetation, as well as with the modern pollen rain data. The pollen taxa of sub recent vegetation of Poaceae and Valeriana correspond to the altitudinal distribution of genera and families of recent vegetation. The pollen taxa of sub recent vegetation of Asteraceae, Clethra, Poaceae and Valeriana correspond to the altitudinal distribution of modern pollen rain taxa. Fern taxa of sub recent vegetation show their main occurrence below ca. $2550 \mathrm{~m}$, corresponding to genera and families of recent vegetation, as well as to modern pollen rain data. 


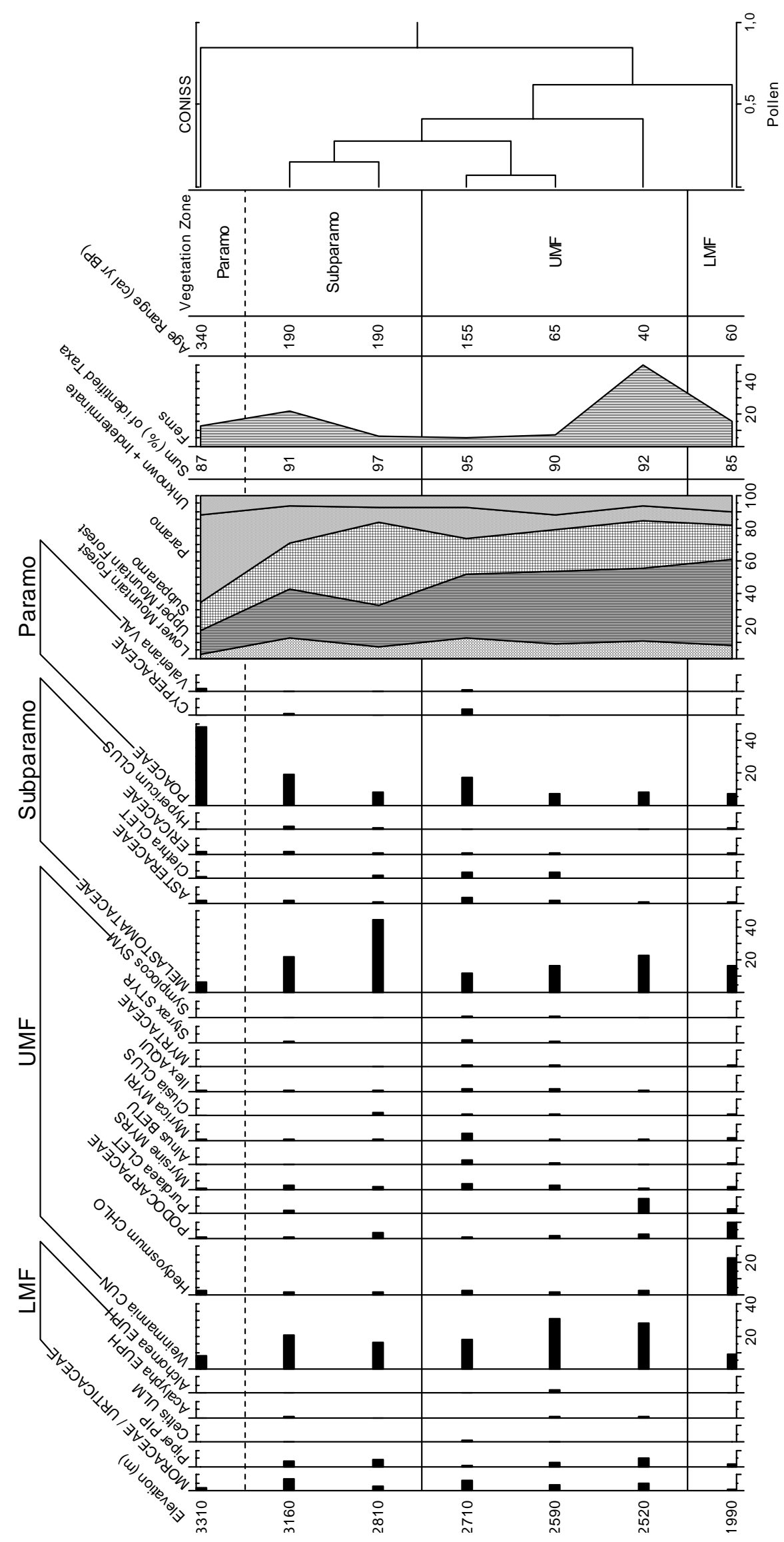

Figure 7.1: Pollen percentage diagram of sub recent pollen input, showing selected pollen taxa, grouped into lower mountain forest (LMF), upper mountain forest (UMF), subparamo and paramo, sums of ecological groups, the share $(\%)$ of identified taxa, the age range and the CONISS dendrogram. 
The modern tree line, reflected by an increases of (sub)-paramo taxa and a decrease mountain forest taxa is between 2710 and $2810 \mathrm{~m}$, corresponding to modern pollen rain data from the ECSF research area (tree line at ca. $2790 \mathrm{~m}$ ). Cluster analysis provided by CONISS estimates the "border line" between subparamo and paramo between 3160 and $3310 \mathrm{~m}$. It has to be considered, that the increase of paramo taxa starts below $3160 \mathrm{~m}$, corresponding to modern pollen rain data.

In general, the altitudinal distribution of sub recent pollen data show higher evidence with modern pollen rain data than with recent vegetation, due to the dispersal properties of pollen in comparison to their producers.

\subsection{Human impact, inferred from a prehistoric terrace in the upper Rio San Francisco valley, southeastern Ecuadorian Andes (unpublished)}

Supplementary to the studied core sites in the upper Rio San Francisco valley (Chapter 3), a terrace (Fig. 7.2), located $3 \mathrm{~km}$ east of the ECSF research area, just above the small village of Sabanilla at ca. $1800 \mathrm{~m}$ elevation (S 03 ${ }^{\circ}$ 58' 05,3", W 079 03' 11,2") has been sampled. During the field work a high number of terraces have been observed in the Rio San Francisco valley, as well as in the whole Loja region (Fig. 7.2). Most of these are prehistoric terraces of pre-Inca and Inca age (Guffroy, personal communication), used for pastures in modern times. Agriculture use has not been observed.

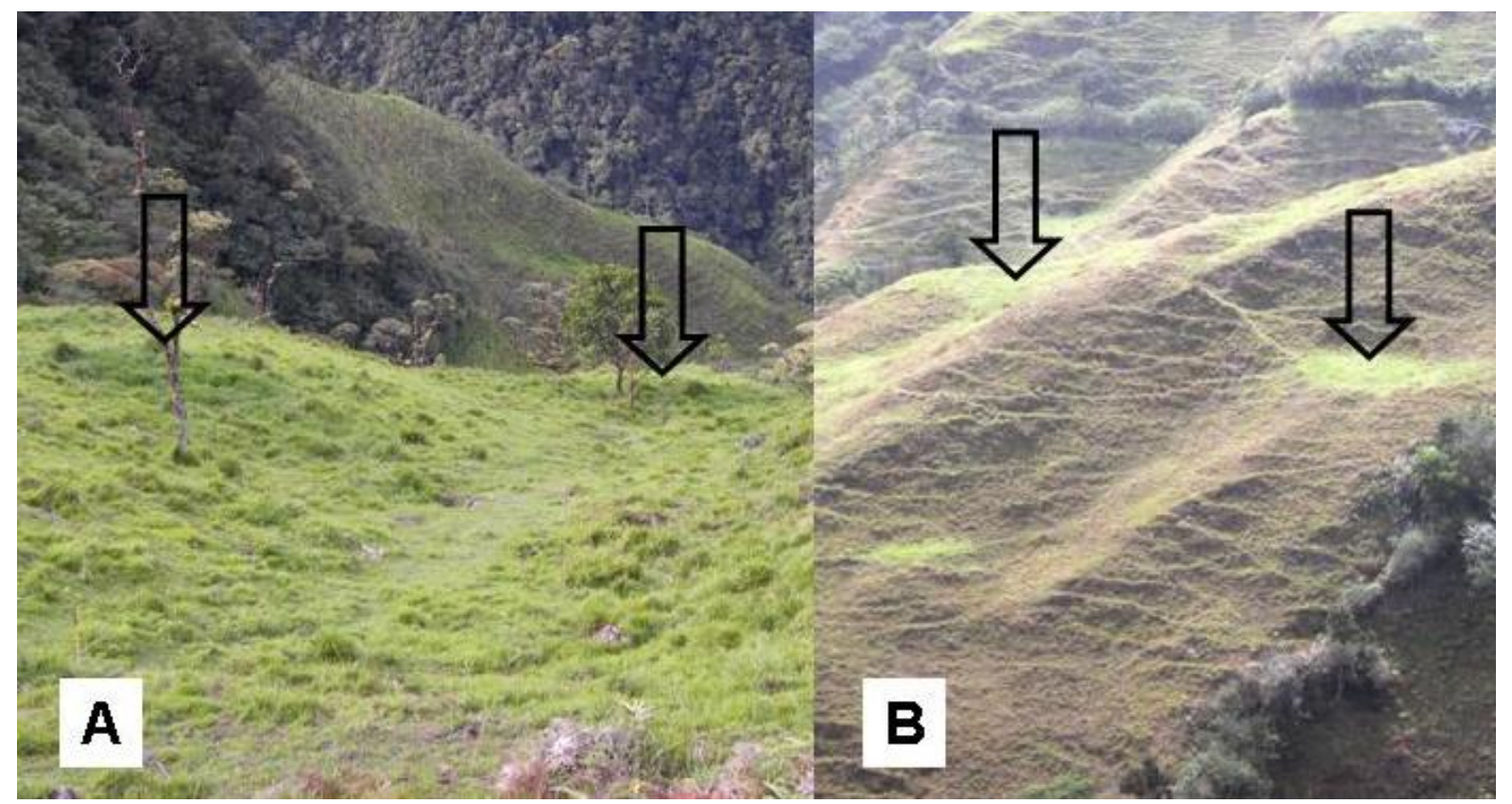

Figure 7.2: Terraces above the small village of Sabanilla in the upper Rio San Francisco valley (A) and below Laguna Cocha Caranga, $5 \mathrm{~km}$ southeast of Loja (B).

Six samples, at $2 \mathrm{~cm}, 13 \mathrm{~cm}, 23 \mathrm{~cm}, 34 \mathrm{~cm}, 50 \mathrm{~cm}$ and $84 \mathrm{~cm}$ depth, were collected by excavation and prepared for palynological studies. AMS radiocarbon dating was not performed. The four uppermost samples were counted on slides for pollen, fern spores, fungal spores and charcoal. The lowermost two samples were not counted, due to the low number of palynomorphs. The software TILIA and TILIAGRAPH were used to plot the pollen and spore data (Grimm 1987). Pollen and spore data are presented in the pollen diagram as percentages of the pollen sum (Fig. 7.3). 


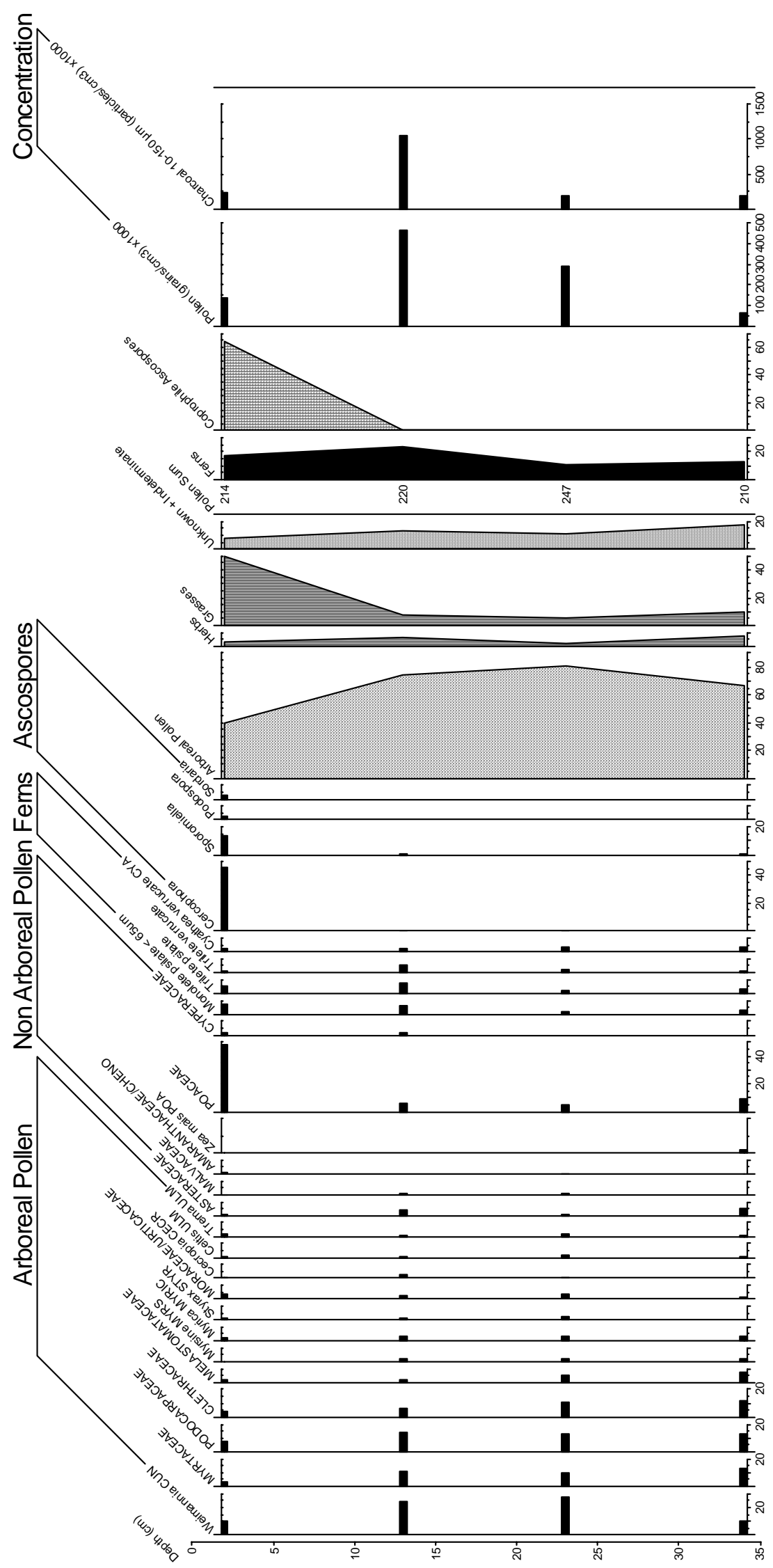

Figure 7.1: Pollen percentage diagram of the Sabanilla terrace, showing selected palynomorphs with the corresponding sums, the pollen sum and the pollen concentration. 
The lowermost sample at $34 \mathrm{~cm}$ depth shows relatively low values of arboreal pollen and relatively high amounts non arboreal pollen. Pollen of Zea mays are only found in this sample, suggesting agricultural activities during this time. The samples at $13 \mathrm{~cm}$ and $23 \mathrm{~cm}$ depth show high values of arboreal pollen, as well as low amounts of Poaceae pollen, indicating a closed forest, according to the late Holocene period of reduction and/or absents of human activities, coupled with forest regeneration (Chapter 3). The uppermost sample at $2 \mathrm{~cm}$ depth shows high amounts of Poaceae pollen and low values of arboreal pollen, indicating an open vegetation type. In comparison with the photographs (Fig. 7.2), this sample well reflects a degraded area. The high occurrence of coprophilous Ascospores, especially the Cercophora type and the Sporomiella type, reflects an intensive pasturing. This well documents the increasing human activities during the last decades. Cercophora sp., Podospora sp., Sordaria sp. and Sporomiella sp. are coprophilous after Van Geel and Aptroot (2006). Ascospore types of coprophilous fungi were used as palaeoenvironmental indicators of settlement at Uitgeest, the Netherlands. The recorded fungal spores Sporormiella type, Podospora type, Cercophora type and Sordaria type indicate the presence of dung (Van Geel et al. 2003).

The data of the pollen and spore record from the prehistoric terrace of Sabanilla well corresponds to the results of the upper Rio San Francisco valley (Chapter 3). 


\section{Summary and Conclusions}

\subsection{Recent vegetation/modern pollen rain studies on the altitudinal gradient in comparison with sub recent pollen data, of the Podocarpus National Park region}

In order to understand the natural composition and dynamics of modern ecosystems and to test the reliability of pollen data in a hotspot of biodiversity, studies of recent vegetation/modern pollen rain relationship on a strong altitudinal gradient in the ECSF research area were coupled with studies of sub recent pollen input, encompassing data from the Podocarpus National Park region.

Studies of recent vegetation/modern pollen rain relationship show a relatively high number of pollen taxa which correspond to the altitudinal distribution of genera and/or families of the recent vegetation. Key taxa for the LMF vegetation unit are Alchornea, Hyeronima and Heliocarpus, for the UMF vegetation unit are Purdiaea, Clusia, Myrsine, Myrtaceae, Podocarpaceae, Rubiaceae, the Symplocos peruviana type, Cyathea spp. and Elaphoglossum and for the (sub)-paramo vegetation unit are Clethra, Cyperaceae, Ericaceae, the Baccharis type, Valeriana and Jamesonia. The UMF pollen taxa of sub recent vegetation show high evidence with genera and families of recent vegetation, as well as with modern pollen rain data. The pollen taxa of sub recent vegetation of Purdiaea, Myrsine, Alnus, Myrica, Ilex, Myrtaceae, Styrax and Symplocos correspond to the altitudinal distribution of genera and families of recent vegetation. The pollen taxa of sub recent vegetation of Hedyosmum, Purdiaea, Myrsine, Clusia, Ilex, Myrtaceae, Styrax and Symplocos correspond to the altitudinal distribution of modern pollen rain taxa. (Sub)-paramo pollen taxa of sub recent vegetation show relatively high evidence with genera and families of recent vegetation, as well as with modern pollen rain data. The pollen taxa of sub recent vegetation of Poaceae and Valeriana correspond to the altitudinal distribution of genera and families of recent vegetation. The pollen taxa of sub recent vegetation of Asteraceae, Clethra, Poaceae and Valeriana correspond to the altitudinal distribution of modern pollen rain taxa.

The lower evidence of LMF pollen taxa with genera and/or families of the recent vegetation depends on wind dispersal. For example Moraceae/Urticaceae, Piper and Acalypha pollen are originated in the LMF, but show their main occurrence in the UMF and (sub)-paramo vegetation zone. This is also observed in the sub recent pollen data from LMF, there is no evidence with genera and families of recent vegetation but perfect evidence with modern pollen rain data. Moraceae/Urticaceae, Piper, Celtis, Acalypha and Alchornea occur on the whole altitudinal gradient, with lowest amounts in the LMF vegetation zone.

Cluster analysis, provided by CONISS verifies the zonation of the vegetation units LMF, UMF and (sub)-paramo for the recent vegetation/modern pollen rain data, as well as for sub recent pollen data with only a little deviation. The modern tree line in the research area is at ca. $2790 \mathrm{~m}$, reflected by an increase of (sub)-paramo taxa and a decrease mountain forest taxa, corresponding to sub recent pollen data (tree line between 2710 and $2810 \mathrm{~m}$ ).

In general, there is higher evidence between modern pollen rain data and sub recent pollen data, than between recent vegetation and sub recent pollen data, on the altitudinal gradient, due to the dispersal properties of pollen. The study of recent vegetation/modern pollen rain relationship in comparison with sub recent pollen data estimates, that fossil pollen data can be used well to interpret past vegetation development, which is needed to reconstruct past climate dynamics. 


\subsection{Late Quaternary vegetation, climate and fire dynamics in the Podocarpus National Park region}

Palaeoenvironmental changes were investigated by pollen, spores, algae and charcoal analysis, in combination with XRF- and magnetic susceptibility-scanning data. The entirety of the multi proxy data sets from the different study sites offers the first comprehensive chronological overview of the late Pleistocene and Holocene vegetation, climate and fire dynamics of southeastern Ecuadorian Andes.

During the late Pleistocene period from ca. 21,000 to 11,200 cal yr BP, cold and moist climatic conditions occurred at the El Tiro-Pass $(2810 \mathrm{~m})$. Grass-paramo was the main vegetation type, where subparamo occurs in modern times. The grass-paramo vegetation was rich in Poaceae, Plantago rigida and Plantago australis, reflecting cold and moist climatic conditions. During the transition from the late Pleistocene to early Holocene (ca. 14,500-9700 cal yr BP) arboreal taxa, mainly Weinmannia, strongly increases at Laguna Cocha Caranga $(2710 \mathrm{~m})$, reflecting higher temperatures. The strongly decrease of Isoetes indicates a higher precipitation, coupled with a lake level rise. At the El Tiro-Pass, the early Holocene from ca. 11,200 to 8900 cal yr BP is characterised by a slightly expansion of subparamo and upper mountain forest vegetation, suggesting a slow warming of climatic conditions during this period. Pollen data from Laguna Rabadilla de Vaca $(3310 \mathrm{~m})$ indicate that herb-paramo, rich in Poaceae, Cyperaceae, Valeriana, and Huperzia, was the main vegetation type during the early Holocene period from ca. 11,500 to 8990 cal yr BP, reflecting cold and relatively wet climatic conditions.

During the mid Holocene period from ca. 8900 to 3300 cal yr BP, upper mountain forest vegetation developed and fires increased at the El Tiro-Pass. A spread of Hedyosmun, Podocarpaceae, Myrsine and Ilex reflects a warmer climate than present day at this elevation. At Laguna Rabadilla de Vaca, Weinmannia expand markedly during this time, indicating warmer climatic conditions due to a spread of shrub-paramo vegetation and/or a shift of the upper mountain forest and subparamo vegetation units into higher elevation. XRF data of the sediment core from Laguna Rabadilla de Vaca suggest a drier period between ca. 8990 and 6380 cal yr BP and a wetter period, with a markedly higher sedimentation rate, between ca. 6380 and 3680 cal yr BP. At Laguna Cocha Caranga, drier climatic conditions occurred during the early to mid Holocene period from ca. 9700 to $6900 \mathrm{cal} \mathrm{yr} \mathrm{BP.} \mathrm{High} \mathrm{values} \mathrm{of}$ Cyperaceae and Isoetes coupled with low concentration of Botryococcus, indicating a lower lake level, caused by a decreasing precipitation. During the period from ca. 6900 to $4200 \mathrm{cal}$ yr BP wetter climatic conditions became established at Laguna Cocha Caranga. Higher concentration of Botryococcus suggests an enlarging of the water body; the marshy lake shores are flooded now.

At Laguna Rabadilla de Vaca, a Poaceae dominated herb-paramo occurred from ca. 3680 cal yr BP until modern times, reflecting cooler climatic conditions relative to the mid Holocene period. XRF data indicates a decrease in precipitation after ca. $3680 \mathrm{cal}$ yr BP. At the El Tiro-Pass, the modern subparamo vegetation became established since $3300 \mathrm{cal} \mathrm{yr} \mathrm{BP.}$ At Laguna Cocha Caranga, drier climatic conditions occurred during the mid to late Holocene period from ca. 4200 to 1300 cal yr BP. Low concentration of Botryococcus coupled with a strongly increase of Cyperaceae indicates a lake level down, due to a reduction of precipitation.

During the late Holocene, probably from ca. 1300 cal yr BP to recent times, grassy vegetation with forest patches and peat bogs established around Laguna Cocha Caranga. Weinmannia, Melastomataceae, Moraceae/Urticaceae, Myrsine and Clethra increases, Myrica and Poaceae decreases, probably as a result of the lower fire intensity. Due to the strong human activities, at the slopes below Laguna Cocha Caranga, a natural vegetation development seems to be improbable. An abrupt increase of Botryococcus concentration and a 
strongly decrease of Cyperaceae and Isoetes reflects a rapid flooding of marshy lake shores at Laguna Cocha Caranga. Higher values of Sphagnum suggest that the mire near the shore line of Laguna Cocha Caranga starts to build up probably at ca. $1300 \mathrm{cal}$ yr BP.

At Laguna Zurita $(2590 \mathrm{~m})$, high occurrences of Cyperaceae and Isoetes indicate marshy lake shores coupled with a lower lake level before ca. $970 \mathrm{cal} \mathrm{yr} \mathrm{BP.} \mathrm{A} \mathrm{following} \mathrm{decrease} \mathrm{of}$ Isoetes and Cyperaceae reflects a lake level rise. The change from a relatively open vegetation type to a closed forest around Laguna Zurita, assumed by a decrease of Poaceae and an increase of Weinmannia and Melastomataceae, is found after ca. $750 \mathrm{cal} \mathrm{yr} \mathrm{BP.} \mathrm{The} \mathrm{pollen}$ records from the upper Rio San Francisco valley, including the ECSF research area, indicate that fires have markedly influenced the stability of the floristic composition of the mountain rainforest ecosystem. After the decrease of fires between ca. 970 to 400 cal yr BP (extrapolated), open areas starts to recover by forests in the upper Rio San Francisco valley. A succession of Weinmannia and Melastomataceae first reacts on decreasing fires. The data from the late Pleistocene and Holocene pollen records (discussed above) also shows different arboreal taxa, mainly Weinmannia, Hedyosmun, Podocarpaceae, Myrsine, Ilex and Melastomataceae, reacting of increasing and deceasing fire intensity. It has to be considered, that Weinmannia, shows the highest potential in reactivity, nearly in every record, reflecting the high sensitivity of this taxa.

Finally, the results from this study suitable reflect over-regional climate development in comparison to other studies from tropical South America (discussed in chapter 3, 4, 5 and 6). The late Pleistocene to early Holocene period of increasing moisture and temperatures is well represented in the records of Laguna Cocha Caranga and the El Tiro-Pass. The mid Holocene phase of probably warmer climate than present day (Holocene thermal optimum) is reflected in the records from Laguna Rabadilla de Vaca and the El Tiro-Pass. The late Holocene establishment of climatic conditions close to modern times is shown in the records of Laguna Rabadilla de Vaca, El Tiro-Pass and Laguna Cocha Caranga, as well as in the records of the upper Rio San Francisco valley.

\subsection{Human impact in the Podocarpus National Park region during the past}

It has to be considered, that human activities influenced the development of mountain rain forest and paramo ecosystems in recent times, as well as during the past. This study explores the beginning and intensity of past human impact on the ecosystem in the Podocarpus National Park region, including the ECSF research area. The charcoal record of Laguna Cocha Caranga $(2710 \mathrm{~m}$ ) shows marked higher fire intensity during the period from ca. 9700 to $1300 \mathrm{cal}$ yr BP. The charcoal record in comparison with Holocene wet/dry phases shows nearly no reaction of increasing or decreasing precipitation during this more than 8000 years long period. Hence, human impact may responsible for the strong fires during this time, probably originated at the slopes below Laguna Cocha Caranga, caused by burning activities in the savannah or dry forest areas of the close dry Loja basin. Due to topographic aspects, early human impact seems to be relevant for the Loja basin, located on a central north-south axis. Laguna Cocha Caranga core site keeps a marginal position to this basin, in the transition zone between wet eastern Cordillera and the dry inter Andean zone. At the El Tiro-Pass (2810 $\mathrm{m})$, fire intensity increases somewhat later after about $7500 \mathrm{cal}$ yr BP. The El Tiro-Pass is located between the Loja basin and the Rio San Francisco site-valley, influenced by strong easterly winds, which blows up the valley.

The pollen record of Laguna Cocha Caranga shows strong expansion of Myrica between ca. 4800 and 1300 cal yr BP. Myrica, accompanies settling activities and prefers growing at degraded areas and along trails. At the El Tiro-Pass fires strongly increase at ca. $3500 \mathrm{cal} \mathrm{yr}$ BP. Archaeological data estimates the beginning of settling activities (Palta culture) in the Loja region at about $4000 \mathrm{yr} \mathrm{BP}$, evidenced with ceramic fragments. 
After probably ca. 1300 cal yr BP fire intensity decreases at Laguna Cocha Caranga and somewhat later between ca. 970 to 400 cal yr BP in the upper Rio San Francisco valley (between ca. 2000 and $2600 \mathrm{~m}$ ). An increase of forest taxa and lower amounts of Poaceae and the crop taxa Zea mays, also observed in the data from the terrace close to Sabanilla (ca. 1800 $\mathrm{m}$ ), indicating a reduction of human activities. The reduction and/or absence of human activities may be a result of civil conflicts during pre-Inca times, the resettling politics of the Inca and the Spanish conquest. After the reduction and/or absence of human influence the forest starts to recover in the upper Rio San Francisco valley.

The most pollen of Zea mays are found in lower altitudes (ECSF T2/250), indicating that the cultivation of Zea mays has happened at the lower parts of the slopes (were overgrown terraces have been observed), close to the modern- and probably past trail system. Due to the installation of the road between Loja and Zamora, as well as the power station next to the ECSF research area in the late 1950s a resettling starts in the upper Rio San Francisco valley The decrease of arboreal pollen during the last ca. 50 years, shown in the records Laguna Zurita and ECSF Refugio, reflects this. At modern times the ECSF research area is a closed forest system surrounded of disturbed landscape with slash and burn activities and pasturing. However, if an ecosystem is natural without any human impact during the past, the "ECSF forest" is not natural. Otherwise, more than for centuries without disturbance can be pointed out as more or less natural.

The temporal differences in the development of human activities between the Loja basin and the upper Rio San Francisco valley may be reflect the origins of this development in the Loja region and a spread over in the valleys. Apparently, the decrease of human activities occurred earlier in the Loja region and some centuries in later the upper Rio San Francisco valley. 


\section{References}

Alvaredo PJ. 2002. Historia de Loja y su Provincia. Municipio de Loja. Industria grafica Senefelder.

Alchon SA. 1991. Native society and disease in colonial Ecuador. Cambridge University Press, Cambridge, England.

Andersen C, Koc N, Moros M. 2004. A highly unstable Holocene climate in the subpolar North Atlantic: evidence from diatoms. Quaternary Science Reviews 23: 2155-2166.

Bader MY. 2007. Tropical alpine tree lines; how ecological processes control vegetation patterning and dynamics. PhD Thesis, Wageningen University, The Netherlands.

Barthlott W, Mutke J, Rafiqpoor MD, Kier G, Kreft H. 2005. Global centres of vascular plant diversity. Nova Acta Leopoldina 92: 61-83.

Batten DJ, Grenfel HR. 1996. Botryococccus. In: Jansonius J, MacGregor DC. (Eds.) Palynology: Principles and Applications. American Association of Stratigraphic Palynologists Foundation 1: 205-214.

Beck E, Bendix J, Kottke I, Makeschin F, Mosandl R. 2008a. Gradients in a Tropical Mountain Ecosystem of Ecuador. Ecological Studies 198, Springer Verlag, Berlin, Heidelberg.

Beck E, Makeschin F, Haubrich F, Richter M, Bendix J, Valerezo C. 2008b. The Ecosystem (Reserva Biológica San Francisco). In: Beck E, Bendix J, Kottke I, Makeschin F, Mosandl R (Eds.) Gradients in a Tropical Mountain Ecosystem of Ecuador. Ecological Studies 198, Springer Verlag, Berlin, Heidelberg, pp. 1-14.

Behling H. 1993. Untersuchungen zur spätpleistozänen und holozänen Vegetations- und Klimageschichte der tropischen Küstenwälder und der Araukarienwälder in Santa Catarina (Südbrasilien). Dissertationes Botanicae 206, J. Cramer, Berlin, Stuttgart.

Behling H, Hooghiemstra H. 2000. Holocene Amazon rain forest - savanna dynamics and climatic implications: High resolution pollen record Laguna Loma Linda in eastern Colombia. Journal of Quaternary Science 15: 687-695.

Behling H, Hooghiemstra H. 2001. Neotropical savanna environments in space and time: Late Quaternary interhemispheric comparisons. In: Markgraf V. (Ed.) Interhemispheric Climate Linkages. Academic Press: 307-323.

Bendix J, Fabian P, Rollenbeck R. 2004. Gradients of fog and rain in a tropical montane cloud forest of southern Ecuador and its chemical composition. Proceedings 3rd Int. Conference on Fog, Fog Collection and Dew, 11-15 Oct. 2004, Cape Town, South Africa.

Bendix J, Rollenbeck R, Richter M, Fabian P, Emck P. 2008. Climate. In: Beck E, Bendix J, Kottke I, Makeschin F, Mosandl R (Eds.) Gradients in a Tropical Mountain Ecosystem of Ecuador. Ecological Studies 198, Springer Verlag, Berlin, Heidelberg, pp. 63-74.

Berrio JC, Hooghiemstra H, Marchant R, Rangel O. 2002. Late-glacial and Holocene history of the dry forest area in the south Colombian Cauca Valley. Journal of Quaternary Science 17: 667-682.

Binford MW, Kolata AL, Brenner M, Janusek JW, Seddon MT, Abbott M, Curtis JH. 1997. Climate variation and the rise and fall of an Andean civilization. Quaternary Research 47: 235-248.

Bohns-Meyer KE, Reichhart K, Ashraf AR, Marques-Toigod M, Mosbrugger V. 2005. Holocene evolution of Itapeva Lake, Rio Grande do Sul, Brazil: Palynomorphs Corg, N, and S records. Journal of South American Earth Sciences 19: 181-192.

Bosman AF, Hooghiemstra H, Cleef AM. 1994. Holocene mire development and climatic change from a high Andean Plantago rigida cushion mire. The Holocene 43: 233-243.

Brummitt N, Lughadha EN. 2003. Biodiversity: Where's Hot and Where's Not. Conservation Biology 17(5): 1442-1448. 
Bush MB, Colinvaux PA. 1988. A 7000-year pollen record from the Amazon lowlands, Ecuador. Vegetatio 76: 141-154.

Bush MB, Colinvaux PA, Wiemann MC, Piperno DR, Liu KB. 1990. Late Pleistocene temperature depression and vegetation change in Ecuadorian Amazonia. Quaternary Research 34: 330-345.

Bush MB, Hansen BCS, Rodbell DT, Seltzer GO, Young KR, Leon B, Abbott MB, Silman MR, Gosling WD. 2005. A 17 000-year history of Andean climate and vegetation change from Laguna de Chochos, Peru. Journal of Quaternary Science 20: 703-714.

Bussmann RW. 2001. The montane forests of Reserva Biologica San Francisco (ZamoraChinchipe, Ecuador). Vegetation zonation and natural regeneration. Erde 132: 9-25.

Bussmann RW. 2005. Bosques andinos del sur de Ecuador, clasificación, regeneración y uso. Revistas peruviana biologica. 12(2): 203-216.

Chepstow-Lusty A, Frogley MR, Bauer BS, Bush MB. 2003. A late Holocene record of arid events from the Cuzco region, Peru. Journal of Quaternary Science 18: 491-502.

Clapperton CM. 1987. Glacial geomorphology, Quaternary glacial sequence and palaeoclimatic inferences in the Ecuadorian Andes. In: Gardiner V. (Ed.) International Geomorphology 1986(2): 843-870.

Clapperton CM. 1993. Quaternary Geology and Geomorphology of South America. Elsevier, Amsterdam.

Cleef AM. 1978. Characteristics of neotropical paramo vegetation and its subantarctic relations. In: Troll C, Lauer W. (Eds.) Geoecological relations between the southern temperate zone and the tropical mountains. Erdwissenschaftliche Forschung XI, Franz Steiner Verlag, Wiesbaden, pp. 365-390.

Colinvaux PA. 1997. Glacial and Postglacial Pollen Records from the Ecuadorian Andes and Amazon. Quaternary Research 48: 69-78.

Colinvaux PA, Frost M, Frost I, Liu K-B, Steinitz-Kannan M. 1988a. Three pollen diagrams of forest disturbance in the western Amazon basin. Review of Palaeobotany and Palynology 55: 73-81.

Colinvaux PA, Olson K, Liu K-B. 1988b. Late-glacial and Holocene pollen diagrams from two endorheic lakes of the Inter-Andean plateau of Ecuador. Review of Palaeobotany and Palynology 55: 83-99.

D’Agostino K, Seltzer G, Baker P, Fritz S, Dunbar R. 2002. Late-Quaternary lowstands of Lake Titicaca: evidence from high-resolution seismic data. Palaeogeography, Palaeoclimatology, Palaeoecology 179: 97-111.

Davis K. 1999. Pollen analysis of Tulare Lake, California: Great Basin-like vegetation in Central California during the full-glacial and early Holocene. Review of Palaeobotany and Palynology 107: 249-257.

Emck P. 2007. A climatology of south Ecuador, with special focus on the major Andean ridge as Atlantic-Pacific climate divide. Dissertation, Universität Erlangen-Nürnberg.

Faegri K, Iversen J. 1989. Textbook of Pollen Analysis. Wiley, New York.

FAO 2003. State of the world's forests. Food and Agriculture Organization of the United Nations, Rome, pp.151, ISBN 92-5-104865-7.

Fey M, Korr C, Maidana N, Carrevedo M, Dietrich S, Corbella H, Haberzettl T, Kuhn G, Lücke A, Mayr C, Ohlendorf C, Schäbitz F, Zolitschka B. (submitted). Palaeoenvironmental changes during the last 1600 years inferred from the sediment record of a cirque lake in southern Patagonia (Laguna Las Vizcachas, Argentina). Palaeogeography, Palaeoclimatology, Palaeoecology.

Geiss CE, Umbanhowar CE, Camill P, Banerjee SK. 2003. Sediment magnetic properties reveal Holocene climate change along the Minnesota prairie-forest ecotone. Journal of Paleolimnology 30: 151-166. 
Granina L, Müller B, Wehrli B. 2004. Origin and dynamics of Fe and Mn sedimentary layers in Lake Baikal. Chemical Geology 205: 55-72.

Grimm EC. 1987. CONISS: A Fortran 77 program for stratigraphically contrained cluster analysis by the method of the incremental sum of squares. Computer and Geosciences 13: 13-35.

Guffroy J. 2004. Catamayo precolombino. Investigaciones arqueologicas en la provincia de Loja (Ecuador). IRD editions, Paris.

Guffroy J. 2006 El Horizonte corrugado: correlations estilisticas y culturales. Bulletin de l'Institut Francais d'Etudes Andines 35 (3): 1-13.

Haberzettl T. 2006. Late Quaternary hydrological variability in southeastern Patagonia 45,000 years of terrestrial evidence from Laguna Potrok Aike. PhD Thesis Institute of Geography, University of Bremen, http://nbn-resolving.de/urn:nbn:de:gbv:46diss000103918, 142.

Haberzettl T, Corbella H, Fey M, Janssen S, Lücke A, Mayr C, Ohlendorf C, Schäbitz F, Schleser G, Wille M, Wulf S, Zolitschka B. 2007. Lateglacial and Holocene wet-dry cycles in southern Patagonia: chronology, sedimentology and geochemistry of a lacustrine record from Laguna Potrok Aike, Argentina. The Holocene 17: 297-310.

Haberzettl T, Fey M, Lücke A, Maidana N, Mayr C, Ohlendorf C, Schäbitz F, Schleser GH, Wille M, Zolitschka B. 2005. Climatically induced lake level changes during the last two millennia as reflected in sediments of Laguna Potrok Aike, southern Patagonia (Santa Cruz, Argentina). Journal of Paleolimnology 33: 283-302.

Haberzettl T, Kück B, Wulf S, Anselmetti F, Ariztegui D, Fey M, Janssen S, Lücke A, Mayr C, Ohlendorf C, Schäbitz F, Schleser G, Wille M, Zolitschka B. (in press). Hydrological variability and explosive volcanic activity in southeastern Patagonia during Oxygen Isotope Stage 3 and the Holocene inferred from lake sediments of Laguna Potrok Aike, Argentina. Palaeogeography, Palaeoclimatology, Palaeoecology.

Haberzettl T, Wille M, Fey M, Janssen S, Lücke A, Mayr C, Ohlendorf C, Schäbitz F, Schleser G, Zolitschka B. 2006. Environmental change and fire history of southern Patagonia (Argentina) during the last five centuries. Quaternary International 158: 72-82.

Hansen BCS, Wright HE, Bradbury JP. 1984. Pollen studies in the Junýn area, Central Peruvian Andes. Geological Society of America Bulletin 95: 1454-1465.

Hansen BCS, Seltzer GO, Wright HE. 1994. Late Quaternary vegetation change in the central Peruvian Andes. Palaeogeography, Palaeoclimatology, Palaeoecology 109: 263285.

Hansen BCS, Rodbell DT. 1995. A late-glacial/Holocene pollen record from the eastern Andes of Northern Peru. Quaternary Research 44: 216-227.

Hansen BCS, Rodbell DT, Seltzer GO, Leon B, Young KR, Abbott M. 2003. Late-glacial and Holocene vegetation history from two sides in the western Cordillera of southwestern Ecuador. Palaeogeography, Palaeoclimatology, Palaeoecology 194: 79-108.

Heine K, Heine JT. 1996. Late Glacial fluctuations: Glacier retreat during Younger Dryas time. Arctic and Alpine Research 28: 496-501.

Homeier J, Werner FA. 2005. Preliminary Checklist of the Spermatophytes of the Reserva San Francisco (Province Zamora-Chinchipe, Ecuador). Department of Plant Ecology, Albrecht-von-Haller-Institute for Plant Sciences, University of Göttingen.

Homeier J, Werner FA, Gradstein SR, Breckle S-W, Richter M. 2008. Potential Vegetation and Floristic Composition of Andean Forests in South Ecuador, with a Focus on the RBSF. In: Beck E, Bendix J, Kottke I, Makeschin F, Mosandl R (Eds.) Gradients in a Tropical Mountain Ecosystem of Ecuador. Ecological Studies 198, Springer Verlag, Berlin, Heidelberg, pp. 87-100.

Hooghiemstra H. 1984. Vegetation and climatic history of the High Plain of Bogota, Colombia. Dissertationes Botanicae. 79, J. Cramer,Vaduz. 
Hooghiemstra H, Cleef AM. 1984. Development of Vegetation and Climatic Sequence of the Area of the High Plain of Bogota. In: Hooghiemstra, H. (Ed.) Vegetation and climatic history of the High Plain of Bogota, Colombia. Dissertationes Botanicae. 79, J. Cramer,Vaduz, pp. 67-133.

Hooghiemstra H, Van der Hammen T. 1993. Late Quaternary vegetation history and paleoecology of Laguna Pedro Palo (subandean forest belt, Eastern Cordillera, Colombia) Review of Palaeobotany and Palynology 77: 235-262.

Kasten S, Zabel M, Heuer V, Hensen, C. 2003. Processes and signals of nonsteady-state diagenesis in deep-sea sediments and their pore waters. In: Wefer G, Mulitza S, Ratmeyer V. (Eds.) The South Atlantic in the Late Quaternary: Reconstruction of Material Budget and Current Systems. Springer, pp. 431-459.

Kim J-H, Schneider RR, Müller PJ, Wefer G. 2002. Interhemispheric comparison of deglacial sea-surface temperature patterns in Atlantic eastern boundary currents. Earth and Planetary Science Letters 194: 383-393.

Lamy F, Hebbeln D, Röhl U, Wefer G. 2001. Holocene rainfall variability in southern Chile: a marine record of latitudinal shifts of the Southern Westerlies. Earth and Planetar Science Letters 185: 369-382.

Lamy F, Kaiser J, Ninnemann U, Hebbeln D, Arz HW, Stoner J. 2004. Antarctic Timing of Surface Water Changes off Chile and Patagonian Ice Sheet Response. Science 304: 1959-1962.

Li S-H, Sun J-M, Zhao H. 2002. Optical dating of dune sands in the northeastern deserts of China. Palaeogeography, Palaeoclimatology, Palaeoecology. 181: 419-429.

Liew PM, Lee CY, Kuo CM. 2006. Holocene thermal optimal and climate variability of East Asian monsoon inferred from forest reconstruction of a subalpine pollen sequence, Taiwan. Earth and Planetary Science Letters 250: 596-605.

Litherland M, Aspen JA, Jemielita RA. 1994. The metamorphic belts of Ecuador. Overseas Memoir of the British Geological Survey 11: 1-147.

Lehnert M, Kessler M, Salazar, LI, Navarrete H, Werner FA, Gradstein SR. 2006. Checklist to the Pteridophytes of the Reserva Biológica San Francisco (Prov. ZamoraChinchipe, Ecuador). Ecotropica (accepted).

Lozano P, Delgado T, Aguirre Z. 2003. Estado actual de la flora endemica exclusive y su distribucion en el Occidente del Parque Nacional Podocarpus. Funbotanica y Herbario y Jardin Botanico. Loja, Ecuador.

Mandl N, Lehnert M, Gradstein SR, Kessler M, Abiy M, Richter M. 2008. The Unique Purdiaea nutans Forest of Southern Ecuador: Abiotic Characteristics and Cryptogamic Diversity. In: Beck E, Bendix J, Kottke I, Makeschin F, Mosandl R (Eds.) Gradients in a Tropical Mountain Ecosystem of Ecuador. Ecological Studies 198, Springer Verlag, Berlin, Heidelberg, pp. 275-280.

Marchant R, Almeida L, Behling H, Berrio JC, Bush M, Cleef A, Duivenvoorden J, Kappelle M, De Oliveira P, Teixeira de Oliveira-Filho A, Lozano-Garcia S, Hooghiemstra H, Ledru MP, Ludlow-Wiechers B, Markgraf V, Mancini V, Paez M, Prieto A, Rangel O, Salgado-Labouriau ML. 2002. Distribution and ecology of parent taxa of pollen lodged within the Latin American Pollen Database. Review of Palaeobotany and Palynology 121: 1-75.

Mayle F, Burbridge R, Killeen TJ. 2000. Millennial-scale dynamics of southern Amazonian rain forests. Science 290: 2291-2294.

McCormac FG, Hogg AG, Blackwell PG, Buck CE, Higham TFG, Reimer PJ. 2004. SHCal04 Southern Hemisphere Calibration 0-11.0 cal kyr BP. Radiocarbon 46: 10871092. 
Melief ABM. 1985. Late Quaternary paleoecology of the Parque Nacional Natural los Nevados (Cordillera Central), and Sumapaz (Cordillera Oriental) areas, Colombia. Doctoral thesis, University of Amsterdam, $162 \mathrm{pp}$.

Niemann H, Haberzettl T, Behling H. 2007. Holocene vegetation, climate and fire dynamics inferred from the (11,700 cal yr BP) Laguna Rabadilla de Vaca multi-proxy record in the southeastern Ecuadorian Andes. The Holocene (in review).

Niemann H, Behling H. 2008a. Recent vegetation/modern pollen rain relationship studies on an altitudinal transect of mountain forest and paramo in the southeastern Ecuadorian Andes. Review of Palaeobotany and Palynology (in review).

Niemann H, Behling H. 2008b. Late Holocene environmental change and human impact inferred from three soil monoliths and the Laguna Zurita multi-proxi record in the southeastern Ecuadorian Andes. Vegetation History and Archaeobotany (in review).

Niemann H, Behling H. 2008c. Late Quaternary vegetation, climate and fire dynamics inferred from the El Tiro record in the southeastern Ecuadorian Andes. Journal of Quaternary Science 23(3): 203-212.

Niemann H, Behling H. 2008d. Past Vegetation and Fire Dynamics. In: Beck E, Bendix J, Kottke I, Makeschin F, Mosandl R (Eds.) Gradients in a Tropical Mountain Ecosystem of Ecuador. Ecological Studies 198, Springer Verlag, Berlin, Heidelberg, pp. 101-112.

Orvis KH, Horn SP. 2000. Quaternary glaciers and climate on Cerro Chirripo, Costa Rica. Quaternary Research 54: 24-37.

Paduano GM, Bush MB, Baker PA, Fritz SC, Seltzer GO. 2003. A vegetation and fire history of Lake Titicaca since the Last Glacial Maximum. Palaeogeography, Palaeoclimatology, Palaeoecology 194: 259-279.

Placzek C, Quade J. 2001. Holocene Lake-Level Fluctuations of Lake Aricota, Southern Peru. Quaternary Research 56: 181-190.

Pohle P. 2008. The People Settled Around Podocarpus National Park. In: Beck E, Bendix J, Kottke I, Makeschin F, Mosandl R. (Eds.) Gradients in a Tropical Mountain Ecosystem of Ecuador. Ecological Studies 198, Springer Verlag, Berlin, Heidelberg, pp 25-36.

Porter SC. 2001. Snowline depression in the tropics during the last glaciation. Quaternary Science Reviews 20: 1067-1091.

Richter M. 2003. Using Epiphytes and Soil Temperatures for Eco-Climatic Interpretations in Southern Ecuador. Erdkunde 57: 161-181.

Richter M, Moreira-Munoz A. 2005. Climatic heterogeneity and plant diversity in southern Ecuador experienced by phytoindication. Review of Peruvian biology 12: 217-238.

Richter T, Van der Gaast S, Koster B, Vaars A, Gieles R, De Stigter H, De Haas H, Van Weering T. 2006. The Avaatech XRF Core Scanner: technical description and applications to NE Atlantic sediments. In: Rothwell RG. (Ed.) New Techniques in Sediment Core analysis. Geological Society, London, Special Publications 267: 39-50.

Rodbell DT. 1992. Late Pleistocene equilibrium-line reconstructions in the Northern Peruvian Andes. Boreas 21: 43-52.

Rodbell DT. 1994. The timing of the last deglaciation in Cordillera Oriental, Northern Peru based on glacial geology and lake sedimentology. Geological Society of America Bulletin 105: 923-934.

Rollenbeck R, Fabian P, Bendix J. 2005. Precipitation dynamics and chemical properties in tropical mountain forests of Ecuador. Advanced Geoscience 6: 1-4.

Rozsypal AA. 2000. Die pleistozäne Glazialmorphologie in Ecuador und Nordperu unter besonderer Betrachtung der Cordillera Oriental bei Loja. Diplomarbeit, Institut für Geographie, Universität Erlangen-Nürnberg. (unpublished).

Rull V, Abbott MB, Polissar PJ, Wolfe AP, Bezada M, Bradley RS. 2005. 15.000-yr pollen record of vegetation change in the high altitude tropical Andes at Laguna Verde Alta, Venezuela. Quaternary Research 64: 308-317. 
Stuiver M, Reimer P. 1993. Extended 14C database and revised CALIB radiocarbon calibration program. Radiocarbon 35: 215-230.

Thompson LG, Mosley-Thompson E, Davis ME, Lin PN, Henderson KA, Cole-Dai J, Bolzan JF, Liu KB. 1995. Late glacial stage and Holocene tropical ice core records from Huascaran, Peru. Science 269: 46-50.

Thompson LG, Mosley-Thompson E, Davis ME, Lin P-N, Henderson K, Mashiotta TA. 2003. Tropical glacier and ice core evidence of climate change on annual to millennial time scales. Climatic Change 59: 137-155.

Tjallingii R, Röhl U, Kölling M, Bickert T. 2007. Influence of the water content on X-ray fluorescence core-scanning measurements in soft marine sediments. Geochemistry, Geophysics, Geosystems 8, Q02004, DOI:02010.01029/02006GC001393.

Tonneijck FH, Van der Plicht J, Jansen B, Verstraten JM, Hooghiemstra H. 2006. Radiocarbon dating of soil organic matter fractions in Andesols in northern Ecuador. Radiocarbon 48(3): 337-353.

Van Geel B, Buurman J, Brinkkemper O, Schelvis J, Aptroot A, van Reenen G, Hakbijl T. 2003. Environmental reconstruction of a Roman Period settlement site in Uitgeest (The Netherlands), with special reference to coprophilous fungi. Journal of Archaeological Science 30: 873-883.

Van Geel B, Aptroot A. 2006: Fossil ascomycetes in Quaternary deposits. Nova Hedwigia 82: 313-329.

Van der Hammen T. 1974. The Pleistocene changes of vegetation and climate in tropical South America. Journal of Biogeography 1: 3-26.

Van der Hammen T. 2003. Ecosistemas zonales en los flancos oeste y este de la Cordillera Central Colombiana (transecto Parque Los Nevados). In: Van der Hammen T, Dos Santos AG. (Eds.) Studies on Tropical Andean Ecosystems, Vol 5, pp 503-526, J. Cramer, Berlin, Stuttgart.

Van der Hammen T, Urrego CG. 1978. Prehistoric man on the Sabana de Bogota: Data for an ecological prehistory 25: 179-190.

Velez MI , Hooghiemstra H, Metcalfe S, Wille M, Berrio JC. 2006. Late Glacial and Holocene environmental and climatic changes from a limnological transect through Colombia, northern South America. Palaeogeography, Palaeoclimatology, Palaeoecology 234: 81-96.

Weninger B, Jöris O, Danzeglocke U. 2004. Calpal: The Cologne radiocarbon CALibration and Palaeoclimate research package. http://www.calpal.de

Weng C, Bush MB, Athens JS, 2002. Holocene climate change and hydrarch succession in lowland Amazonian Ecuador. Review of Palaeobotany and Palynology 120: 73-90.

Weng C, Bush M, Silman MR. 2004. An analysis of modern pollen rain on an elevational gradient in southern Peru. Journal of Tropical Ecology 20: 113-124.

Wille $\mathbf{M}$, Hooghiemstra $\mathbf{H}$, Behling $\mathbf{H}$, van der Borg $\mathbf{K}$, Jose Negret A. 2001. Environmental change in the Colombian subandean forest belt from 8 pollen records: in the last 50 kyr. Vegetation History and Archaeobotany 10: 61-77.

Wille M, Hooghiemstra H, Hofstede R, Fehse J, Sevink J. 2002. Upper forest line reconstruction in a deforested area in northern Ecuador based on pollen and vegetation analysis. Journal of Tropical Ecology 18(3): 409-40. 
Appendix A - Identified pollen and spore types 


\begin{tabular}{|c|c|c|c|c|c|}
\hline Genera/Species & Family & $\begin{array}{l}\text { Aperture } \\
\text { Sculpture }\end{array}$ & $\begin{array}{c}\text { Size }(\mu \mathrm{m}) \\
\text { (equat./polar) }\end{array}$ & $\begin{array}{l}\text { Veget. Unit } \\
\text { Order }\end{array}$ & Foto \\
\hline \multicolumn{6}{|l|}{ POLLEN TYPES } \\
\hline \multirow[t]{2}{*}{ Saurauia } & Actinidiaceae & $\begin{array}{l}\text { Tricolporate } \\
\text { scabrate }\end{array}$ & $13-15 \times 14-20$ & $\begin{array}{l}\text { LMF } \\
\text { Arb.Pollen }\end{array}$ & 1 \\
\hline & cf. Alismataceae & $\begin{array}{l}\text { Periporate } \\
\text { echinate }\end{array}$ & $22-28$ & $\begin{array}{l}\text { Subparamo } \\
\text { Non Arb.Pollen }\end{array}$ & \\
\hline Bomarea & Alstroemeriaceae & $\begin{array}{l}\text { Monocolpate } \\
\text { reticulate }\end{array}$ & $18-25 \times 45-65$ & $\begin{array}{l}\text { Subparamo } \\
\text { Non Arb.Pollen }\end{array}$ & 2 \\
\hline Alzatea & Alzateaceae & $\begin{array}{l}\text { Tricolporate } \\
\text { psilate }\end{array}$ & $17-18 \times 22-25$ & $\begin{array}{l}\text { LMF } \\
\text { Arb.Pollen }\end{array}$ & \\
\hline \multirow[t]{2}{*}{ Alternanthera } & Amaranthaceae & $\begin{array}{l}\text { Periporate } \\
\text { granulate/fenestrate }\end{array}$ & $20-25$ & $\begin{array}{l}\text { LMF } \\
\text { Non Arb.Pollen }\end{array}$ & \\
\hline & $\begin{array}{l}\text { Amaranthaceae/ } \\
\text { Chenopodiaceae }\end{array}$ & $\begin{array}{l}\text { Periporate } \\
\text { psilate }\end{array}$ & $18-26$ & $\begin{array}{l}\text { LMF } \\
\text { Non Arb.Pollen }\end{array}$ & 3 \\
\hline Hydrocotyle & Apiaceae & $\begin{array}{l}\text { Tricolporate } \\
\text { scabrate }\end{array}$ & $15-24 \times 18-31$ & $\begin{array}{l}\text { Paramo } \\
\text { Aquatic (NAP) }\end{array}$ & \\
\hline \multirow[t]{2}{*}{ Type 1} & Apiaceae & $\begin{array}{l}\text { Tricolporate } \\
\text { psilate }\end{array}$ & $18-25$ & $\begin{array}{l}\text { Paramo } \\
\text { Aquatic (NAP) }\end{array}$ & \\
\hline & Apocynaceae & $\begin{array}{l}\text { Periporate } \\
\text { psilate }\end{array}$ & $30-45$ & $\begin{array}{l}\text { LMF } \\
\text { Non Arb.Pollen }\end{array}$ & 4 \\
\hline Ilex & Aquifoliaceae & $\begin{array}{l}\text { Tricolporate } \\
\text { clavate }\end{array}$ & $21-28 \times 28-39$ & $\begin{array}{l}\text { UMF } \\
\text { Arb.Pollen }\end{array}$ & 5 \\
\hline Oreopanax & Araliaceae & $\begin{array}{l}\text { Tricolporate } \\
\text { (micro)reticulate }\end{array}$ & $18-22 \times 24-30$ & $\begin{array}{l}\text { Subparamo } \\
\text { Arb.Pollen }\end{array}$ & 6,7 \\
\hline \multirow[t]{2}{*}{ Schefflera } & Araliaceae & $\begin{array}{l}\text { Tricolporate } \\
\text { reticulate }\end{array}$ & $21-26 \times 30-42$ & $\begin{array}{l}\text { UMF } \\
\text { Arb.Pollen }\end{array}$ & \\
\hline & Arecaceae & $\begin{array}{l}\text { Monocolpate } \\
\text { (micro)reticulate }\end{array}$ & $15-17 \times 22-28$ & $\begin{array}{l}\text { LMF } \\
\text { Arb.Pollen }\end{array}$ & \\
\hline subf. Asterioideae & Asteraceae & $\begin{array}{l}\text { Tricolporate } \\
\text { (micro)echinate }\end{array}$ & variable & $\begin{array}{l}\text { Subparamo } \\
\text { Non Arb.Pollen }\end{array}$ & \\
\hline Ambrosia type & Asteraceae & $\begin{array}{l}\text { Tricolporate } \\
\text { echinate }\end{array}$ & $11-16 \times 15-25$ & $\begin{array}{l}\text { Subparamo } \\
\text { Non Arb.Pollen }\end{array}$ & 8 \\
\hline Baccharis type & Asteraceae & $\begin{array}{l}\text { Tricolporate } \\
\text { echinate }\end{array}$ & $14-22$ & $\begin{array}{l}\text { Subparamo } \\
\text { Non Arb.Pollen }\end{array}$ & 9 \\
\hline Gynoxis type & Asteraceae & $\begin{array}{l}\text { Tricolporate } \\
\text { echinate }\end{array}$ & $28-35$ & $\begin{array}{l}\text { Subparamo } \\
\text { Non Arb.Pollen }\end{array}$ & 10 \\
\hline Lepidaploa type & Asteraceae & $\begin{array}{l}\text { Tricolporate } \\
\text { echinate/fenestrate }\end{array}$ & $28-45$ & $\begin{array}{l}\text { LMF/UMF } \\
\text { Non Arb.Pollen }\end{array}$ & 11 \\
\hline Mikania type & Asteraceae & $\begin{array}{l}\text { Tricolporate } \\
\text { echinate }\end{array}$ & $13-15$ & $\begin{array}{l}\text { LMF/UMF } \\
\text { Non Arb.Pollen }\end{array}$ & 12 \\
\hline Piptocoma type & Asteraceae & $\begin{array}{l}\text { Tricolporate } \\
\text { echinate }\end{array}$ & $25-35$ & $\begin{array}{l}\text { LMF/UMF } \\
\text { Non Arb.Pollen }\end{array}$ & 13 \\
\hline Senecio type & Asteraceae & $\begin{array}{l}\text { Tricolporate } \\
\text { echinate }\end{array}$ & $20-25 \times 28-35$ & $\begin{array}{l}\text { Subparamo } \\
\text { Non Arb.Pollen }\end{array}$ & 14 \\
\hline Vernonia type & Asteraceae & $\begin{array}{l}\text { Triporate } \\
\text { echinate }\end{array}$ & $22-26 \times 28-36$ & $\begin{array}{l}\text { Subparamo } \\
\text { Non Arb.Pollen }\end{array}$ & 15 \\
\hline Begonia type & Begoniaceae & $\begin{array}{l}\text { Tricolporate } \\
\text { striate }\end{array}$ & $17-19 \times 33-36$ & $\begin{array}{l}\text { LMF } \\
\text { Arb.Pollen }\end{array}$ & \\
\hline Alnus & Betulaceae & $\begin{array}{l}\text { Stephanoporate } \\
\text { psilate/scabrate }\end{array}$ & $22-35$ & $\begin{array}{l}\text { UMF } \\
\text { Arb.Pollen }\end{array}$ & 16 \\
\hline Cydista type & Bignoniaceae & $\begin{array}{l}\text { (Tri)colpate } \\
\text { (micro)reticulate }\end{array}$ & $22-27$ & $\begin{array}{l}\text { LMF } \\
\text { Arb.Pollen }\end{array}$ & 17 \\
\hline Tabebuia type & Bignoniaceae & $\begin{array}{l}\text { Tricolpate } \\
\text { reticulate }\end{array}$ & $35-38 \times 41-46$ & $\begin{array}{l}\text { LMF } \\
\text { Arb.Pollen }\end{array}$ & \\
\hline Pseudobombax & Bombacaceae & $\begin{array}{l}\text { Tricolporate } \\
\text { reticulate }\end{array}$ & $40-45 \times 65-80$ & $\begin{array}{l}\text { LMF } \\
\text { Arb.Pollen }\end{array}$ & 18 \\
\hline
\end{tabular}




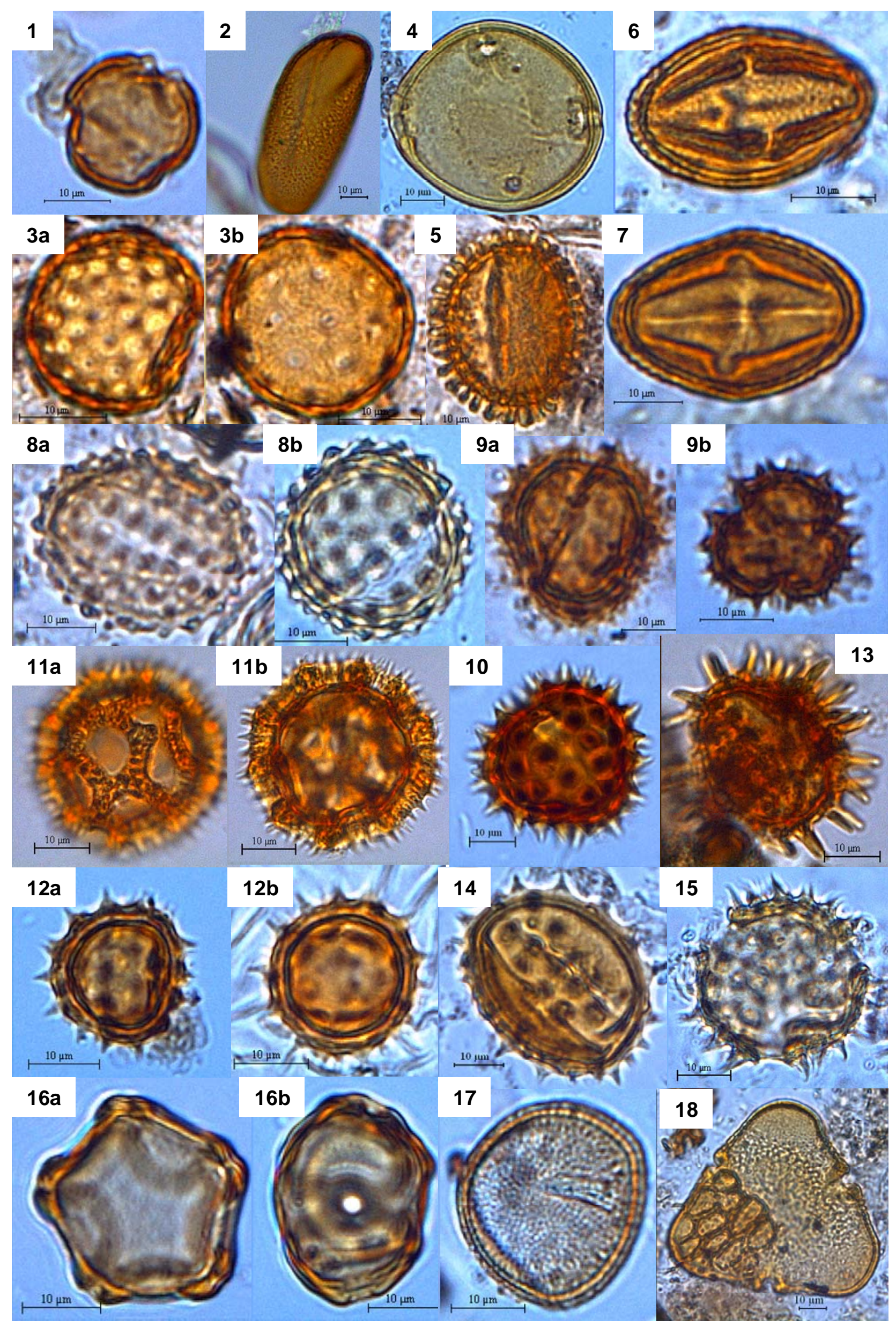


POLLEN TYPES

\section{Cordia type}

Moritzia type

Boraginaceae

Tournefortia

Boraginaceae

Tournefortia

Puya

Styloceras type

Centropogon

Lysipomia

Viburnum

Cecropia

Maytenus

Hedyosmum

Clethra

Purdiaea

Clusia

Vismia

Weinmannia

Vallea type

Vaccinium

Type 1

Type 2

Type 3

Type 4

Type 5

Acalypha

Alchornea

\section{Boraginaceae}

Brassicaceae

Bromeliaceae

Buxaceae

Campanulaceae

Campanulaceae

Caprifoliaceae

Cecropiaceae

Celastraceae

Chloranthaceae

Clethraceae

Clethraceae

Clusiaceae

Clusiaceae

Cunoniaceae

Cyperaceae

Elaeocarpaceae

Ericaceae

Ericaceae

Ericaceae

Ericaceae

Ericaceae

Ericaceae

Euphorbiaceae

Euphorbiaceae
Tri(col)porate

echinate

Stephanocolporate

psilate/scabrate

Tri(col)porate

bacculate

Tricolporate

reticulate

Monocolpate

reticulate

Periporate

reticulate

Tricolporate

psilate

Stephanocolpor.

striate

Tricolporate

reticulate

Diporate

psilate

Tricolporate

reticulate

Inaperturate

clavate

Tricolporate

psilate

Tricolporate

psilate

Tricolporate

reticulate

Tricolporate

reticulate

Tricolporate

(micro)reticulate

Periporate

psilate

Tricolporate

psilate

Tricolpate (Tetrade)

psilate

Tricolpate (Tetrade)

scabrate

Tricolpate (Tetrade)

scabrate

Tricolpate (Tetrade)

scabrate

Tricolpate (Tetrade)

psilate

Tricolpate (Tetrade)

reticulate

3-5 Colporate

psilate/scabrate

Tricolporate

scabrate
35-42 $\begin{array}{ll}\text { Subparamo } \\ & \text { Non Arb.Pollen }\end{array}$

14-20x22-29 Paramo

Non Arb.Pollen

32-35 LMF

Paramo

Non Arb.Pollen

22-45×60-80 Paramo

Non Arb.Pollen

28-40 Paramo

Non Arb.Pollen

25-35x38-48 Subparamo

Non Arb.Pollen

16-24×38-50 Paramo

Non Arb.Pollen

18-24x23-32 LMF

Arb.Pollen

6-9x8-13 LMF

Arb.Pollen

25-29×33-38 UMF

Arb.Pollen

28-35

UMF

Arb.Pollen

12-18x16-22 Subparamo 25

Arb.Pollen

9-16×10-17 UMF

Arb.Pollen

15-20x17-23 UMF

Arb.Pollen

21-30x28-36 LMF

Arb.Pollen

7-10x9-16 UMF

Arb.Pollen

variable Paramo

Aquatic (NAP)

7-10x9-16 LMF

Arb.Pollen

35-48 Paramo

Arb.Pollen

25-40 Subparamo

Arb.Pollen

40-50 Subparamo

Arb.Pollen

50-60 Subparamo

Arb.Pollen

28-38 Subparamo

Arb.Pollen

40-50 Subparamo

Arb.Pollen

13-21

LMF

24-36 LMF

Arb.Pollen

Arb.Pollen 


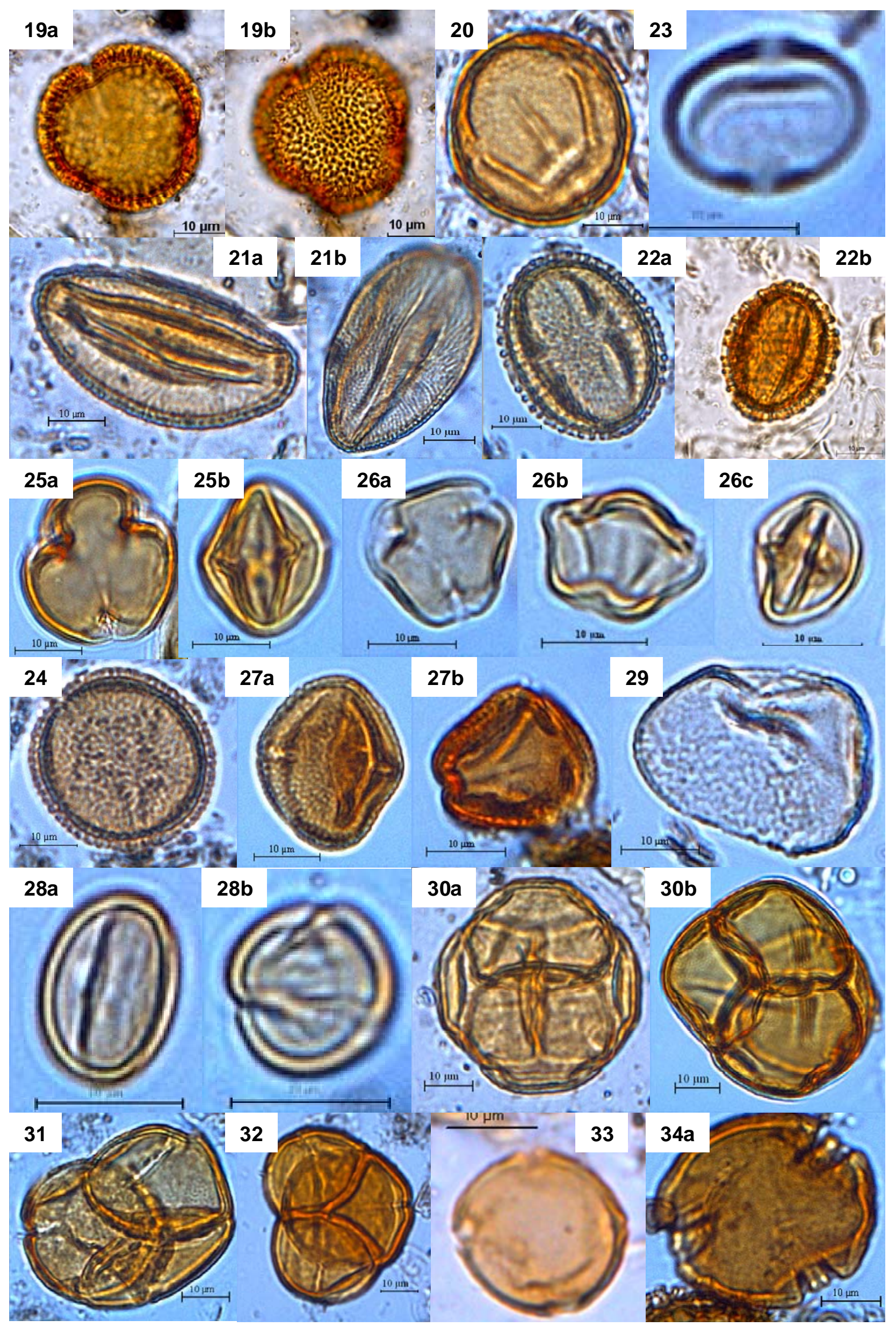




\begin{tabular}{|c|c|c|c|c|c|}
\hline Genera/Species & Family & $\begin{array}{l}\text { Aperture } \\
\text { Sculpture }\end{array}$ & $\begin{array}{c}\text { Size }(\mu \mathrm{m}) \\
\text { (equat./polar) }\end{array}$ & $\begin{array}{l}\text { Veget. Unit } \\
\text { Order }\end{array}$ & Foto \\
\hline \multicolumn{6}{|l|}{ POLLEN TYPES } \\
\hline Croton & Euphorbiaceae & $\begin{array}{l}\text { Inaperturate } \\
\text { clavate }\end{array}$ & $50-70$ & $\begin{array}{l}\text { LMF } \\
\text { Arb.Pollen }\end{array}$ & \\
\hline Hyeronima & Euphorbiaceae & $\begin{array}{l}\text { Tricolporate } \\
\text { (micro)reticulate }\end{array}$ & $8-13 \times 22-34$ & $\begin{array}{l}\text { LMF } \\
\text { Arb.Pollen }\end{array}$ & 35 \\
\hline Phyllanthus type & Euphorbiaceae & $\begin{array}{l}\text { Tricolporate } \\
\text { (micro)reticulate }\end{array}$ & $19-24 \times 23-29$ & $\begin{array}{l}\text { LMF } \\
\text { Arb.Pollen }\end{array}$ & \\
\hline Sebastiana type & Euphorbiaceae & $\begin{array}{l}\text { Tricolporate } \\
\text { reticulate }\end{array}$ & $15-19 \times 17-22$ & $\begin{array}{l}\text { LMF } \\
\text { Arb.Pollen }\end{array}$ & \\
\hline Sapium & Euphorbiaceae & $\begin{array}{l}\text { Tricolporate } \\
\text { supra-reticulate }\end{array}$ & $27-35 \times 45-70$ & $\begin{array}{l}\text { LMF } \\
\text { Arb.Pollen }\end{array}$ & 36,37 \\
\hline Lupinus type & Fabaceae & $\begin{array}{l}\text { Tricolporate } \\
\text { (micro)reticulate }\end{array}$ & $21-27 \times 25-33$ & $\begin{array}{l}\text { Subparamo } \\
\text { Non Arb.Pollen }\end{array}$ & \\
\hline Type 1 & cf. FABACEAE & $\begin{array}{l}\text { Tricolporate } \\
\text { reticulate }\end{array}$ & $12-16 \times 18-22$ & $\begin{array}{l}\text { LMF } \\
\text { Arb.Pollen }\end{array}$ & 38 \\
\hline Type 2 & cf. FABACEAE & $\begin{array}{l}\text { Tricolporate } \\
\text { reticulate }\end{array}$ & $16-22 \times 21-27$ & $\begin{array}{l}\text { LMF } \\
\text { Arb.Pollen }\end{array}$ & \\
\hline Type 3 & cf. FABACEAE & $\begin{array}{l}\text { Tricolporate } \\
\text { psilate }\end{array}$ & $14-18 \times 19-25$ & $\begin{array}{l}\text { LMF } \\
\text { Arb.Pollen }\end{array}$ & \\
\hline Casearia & Flacourtiaceae & $\begin{array}{l}\text { Stephanocolporate } \\
\text { psilate }\end{array}$ & $25-32 \times 30-38$ & $\begin{array}{l}\text { Subparamo } \\
\text { Arb.Pollen }\end{array}$ & 39 \\
\hline Gentiana type & Gentianaceae & $\begin{array}{l}\text { Tricolporate } \\
\text { reticulate }\end{array}$ & $25-35 \times 30-40$ & $\begin{array}{l}\text { Paramo } \\
\text { Non Arb.Pollen }\end{array}$ & 40 \\
\hline Macrocarpea & Gentianaceae & $\begin{array}{l}\text { Periporate } \\
\text { reticulate }\end{array}$ & $25-33$ & $\begin{array}{l}\text { LMF/UMF } \\
\text { Arb.Pollen }\end{array}$ & 41 \\
\hline Geranium & Geraniaceae & $\begin{array}{l}\text { Tricolpate } \\
\text { per-reticulate }\end{array}$ & $60-90$ & $\begin{array}{l}\text { Paramo } \\
\text { Non Arb.Pollen }\end{array}$ & 42 \\
\hline Gunnera & Gunneraceae & $\begin{array}{l}\text { Tricolpate } \\
\text { (micro)reticulate }\end{array}$ & $23-35$ & $\begin{array}{l}\text { Subparamo } \\
\text { Non Arb.Pollen }\end{array}$ & 43 \\
\hline Myriophyllum & Haloragiaceae & $\begin{array}{l}\text { Stephanoporate } \\
\text { psilate/scabrate }\end{array}$ & $23-38$ & $\begin{array}{l}\text { Paramo } \\
\text { Aquatic (NAP) }\end{array}$ & 44 \\
\hline Hypericum & Hypericaceae & $\begin{array}{l}\text { Tricolporate } \\
\text { (micro)reticulate }\end{array}$ & $14-21 \times 24-35$ & $\begin{array}{l}\text { Subparamo } \\
\text { Non Arb.Pollen }\end{array}$ & 45 \\
\hline Sisyrinchium type & Iridaceae & $\begin{array}{l}\text { Monocolpate } \\
\text { (micro)reticulate }\end{array}$ & $18-25 \times 35-45$ & $\begin{array}{l}\text { Paramo } \\
\text { Non Arb.Pollen }\end{array}$ & 46 \\
\hline Juglans & Juglandaceae & $\begin{array}{l}\text { Periporate } \\
\text { psilate }\end{array}$ & $30-45$ & $\begin{array}{l}\text { LMF } \\
\text { Arb.Pollen }\end{array}$ & 47 \\
\hline Eschweilera & Lecythidaceae & $\begin{array}{l}\text { Tricolporate } \\
\text { (micro)reticulate }\end{array}$ & $17-23 \times 21-26$ & $\begin{array}{l}\text { LMF } \\
\text { Arb.Pollen }\end{array}$ & 48 \\
\hline \multirow[t]{2}{*}{ Utricularia } & Lentibulariaceae & $\begin{array}{l}\text { Stephanocolporate } \\
\text { psilate }\end{array}$ & $28-35 \times 38-45$ & $\begin{array}{l}\text { Paramo } \\
\text { Aquatic (NAP) }\end{array}$ & 49 \\
\hline & Liliaceae & $\begin{array}{l}\text { Monocolpate } \\
\text { psilate }\end{array}$ & $18-25$ & $\begin{array}{l}\text { Subparamo } \\
\text { Non Arb.Pollen }\end{array}$ & 50 \\
\hline Gaiadendron & Loranthaceae & $\begin{array}{l}\text { Syncolpate } \\
\text { psilate/scabrate }\end{array}$ & $18-25$ & $\begin{array}{l}\text { LMF } \\
\text { Arb.Pollen }\end{array}$ & \\
\hline
\end{tabular}




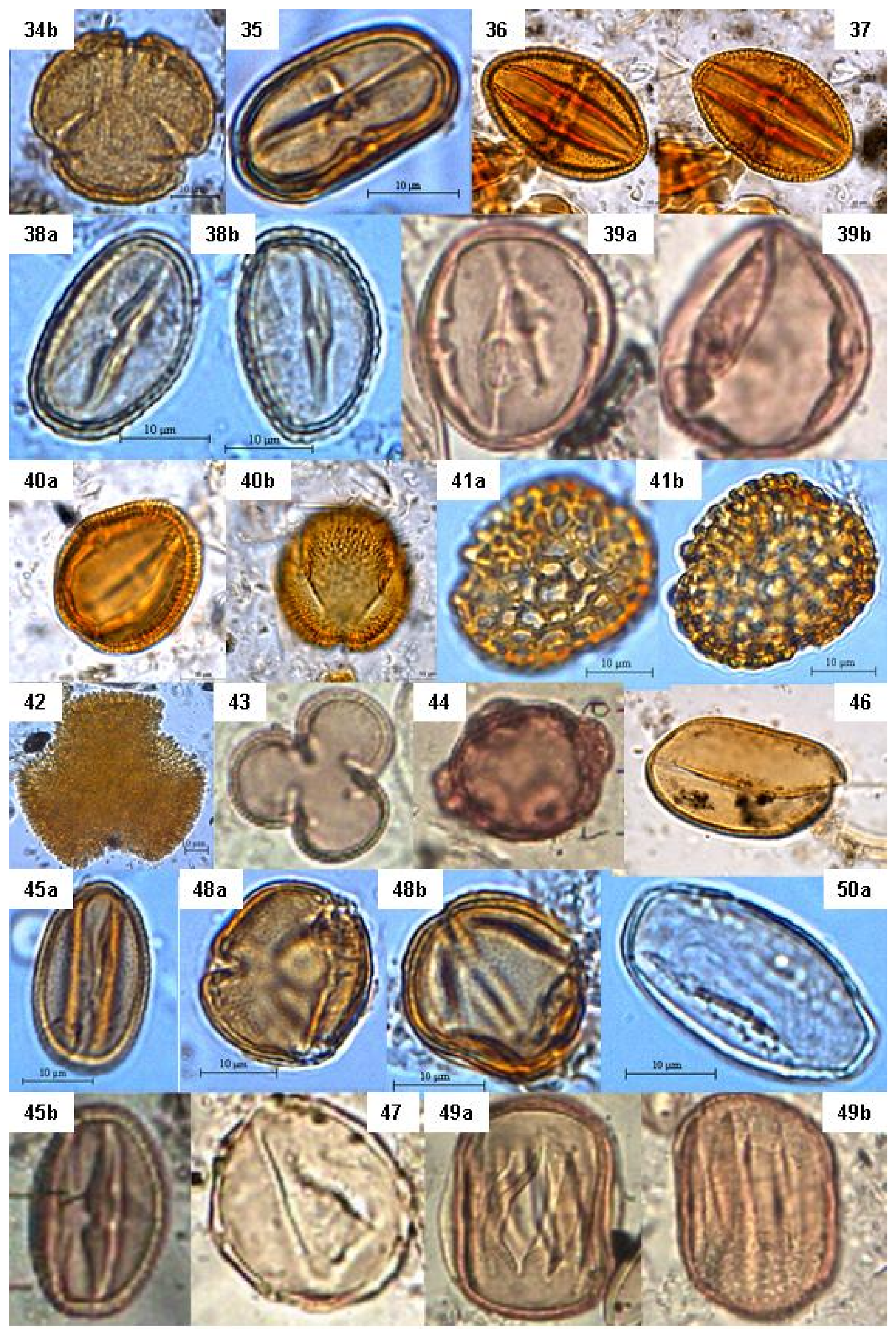




\begin{tabular}{|c|c|c|c|c|c|}
\hline Genera/Species & Family & $\begin{array}{l}\text { Aperture } \\
\text { Sculpture }\end{array}$ & $\begin{array}{c}\text { Size }(\mu \mathrm{m}) \\
\text { (equat./polar) }\end{array}$ & $\begin{array}{l}\text { Veget. Unit } \\
\text { Order }\end{array}$ & Foto \\
\hline \multicolumn{6}{|l|}{ POLLEN TYPES } \\
\hline Tristerix type & Loranthaceae & $\begin{array}{l}\text { Syncolpate } \\
\text { (micro)echinate }\end{array}$ & $37-54$ & $\begin{array}{l}\text { LMF } \\
\text { Arb.Pollen }\end{array}$ & 51 \\
\hline \multirow[t]{2}{*}{ Cuphea type } & Lythraceae & $\begin{array}{l}\text { Syncolporate } \\
\text { striate }\end{array}$ & $16-21$ & $\begin{array}{l}\text { LMF } \\
\text { Non Arb.Pollen }\end{array}$ & 52 \\
\hline & Malvaceae & $\begin{array}{l}\text { Tricolporate } \\
\text { echinate }\end{array}$ & $29-40$ & $\begin{array}{l}\text { LMF } \\
\text { Non Arb.Pollen }\end{array}$ & 53 \\
\hline Type 1 & Melastomataceae & $\begin{array}{l}\text { Heterocolporate } \\
\text { psilate/scabrate }\end{array}$ & $10-16 \times 15-25$ & $\begin{array}{l}\text { Subparamo } \\
\text { Arb.Pollen }\end{array}$ & 54 \\
\hline Type 2 & Melastomataceae & $\begin{array}{l}\text { Heterocolporate } \\
\text { psilate/scabrate }\end{array}$ & $16-22 \times 25-33$ & $\begin{array}{l}\text { Subparamo } \\
\text { Arb.Pollen }\end{array}$ & \\
\hline Cedrela & Meliaceae & $\begin{array}{l}\text { Stephanocolporate } \\
\text { (mikro)echinate }\end{array}$ & $24-30 \times 25-32$ & $\begin{array}{l}\text { LMF } \\
\text { Arb.Pollen }\end{array}$ & 55 \\
\hline \multirow[t]{4}{*}{ Ruagea } & Meliaceae & $\begin{array}{l}\text { Stephanocolporate } \\
\text { psilate/scabrate }\end{array}$ & $30-38$ & $\begin{array}{l}\text { LMF } \\
\text { Arb.Pollen }\end{array}$ & 56 \\
\hline & Menispermaceae & $\begin{array}{l}\text { Tricolporate } \\
\text { (micro)reticulate } \\
\text { Inaperturate }\end{array}$ & $13-15$ & $\begin{array}{l}\text { LMF } \\
\text { Arb.Pollen }\end{array}$ & 57 \\
\hline & Mimosaceae & $\begin{array}{l}\text { (Polyade) } \\
\text { verrucate/bacculate }\end{array}$ & variable & $\begin{array}{l}\text { LMF } \\
\text { Arb.Pollen }\end{array}$ & 58 \\
\hline & $\begin{array}{l}\text { Moraceae/ } \\
\text { Urticaceae }\end{array}$ & $\begin{array}{l}\text { Di/Triporate } \\
\text { psilate/scabrate }\end{array}$ & $13-18$ & $\begin{array}{l}\text { LMF } \\
\text { Arb.Pollen }\end{array}$ & 59 \\
\hline Myrica & Myricaceae & $\begin{array}{l}\text { Triporate } \\
\text { scabrate }\end{array}$ & $27-35$ & $\begin{array}{l}\text { UMF } \\
\text { Arb.Pollen }\end{array}$ & 60 \\
\hline Cybianthus type & Myrsinaceae & $\begin{array}{l}\text { Tricolporate } \\
\text { psilate/scabrate }\end{array}$ & $18-25$ & $\begin{array}{l}\text { UMF } \\
\text { Arb.Pollen }\end{array}$ & 61 \\
\hline Gaissanthus type & Myrsinaceae & $\begin{array}{l}\text { Stephanocolporate } \\
\text { psilate/scabrate }\end{array}$ & $16-24$ & $\begin{array}{l}\text { UMF } \\
\text { Arb.Pollen }\end{array}$ & 62 \\
\hline Myrsine & Myrsinaceae & $\begin{array}{l}\text { Stephanocolporate } \\
\text { scabrate }\end{array}$ & $16-24$ & $\begin{array}{l}\text { UMF } \\
\text { Arb.Pollen }\end{array}$ & 63 \\
\hline Myrteola & Myrtaceae & $\begin{array}{l}\text { Syncolpate } \\
\text { verrucate/rugulate }\end{array}$ & $26-35$ & $\begin{array}{l}\text { UMF } \\
\text { Arb.Pollen }\end{array}$ & 64 \\
\hline Type 1 & Myrtaceae & $\begin{array}{l}\text { Syncolpate } \\
\text { psilate/scabrate }\end{array}$ & $26-35$ & $\begin{array}{l}\text { UMF } \\
\text { Arb.Pollen }\end{array}$ & 65 \\
\hline Type 2 & Myrtaceae & $\begin{array}{l}\text { Syncolpate } \\
\text { verrucate }\end{array}$ & $16-21$ & $\begin{array}{l}\text { UMF } \\
\text { Arb.Pollen }\end{array}$ & \\
\hline
\end{tabular}




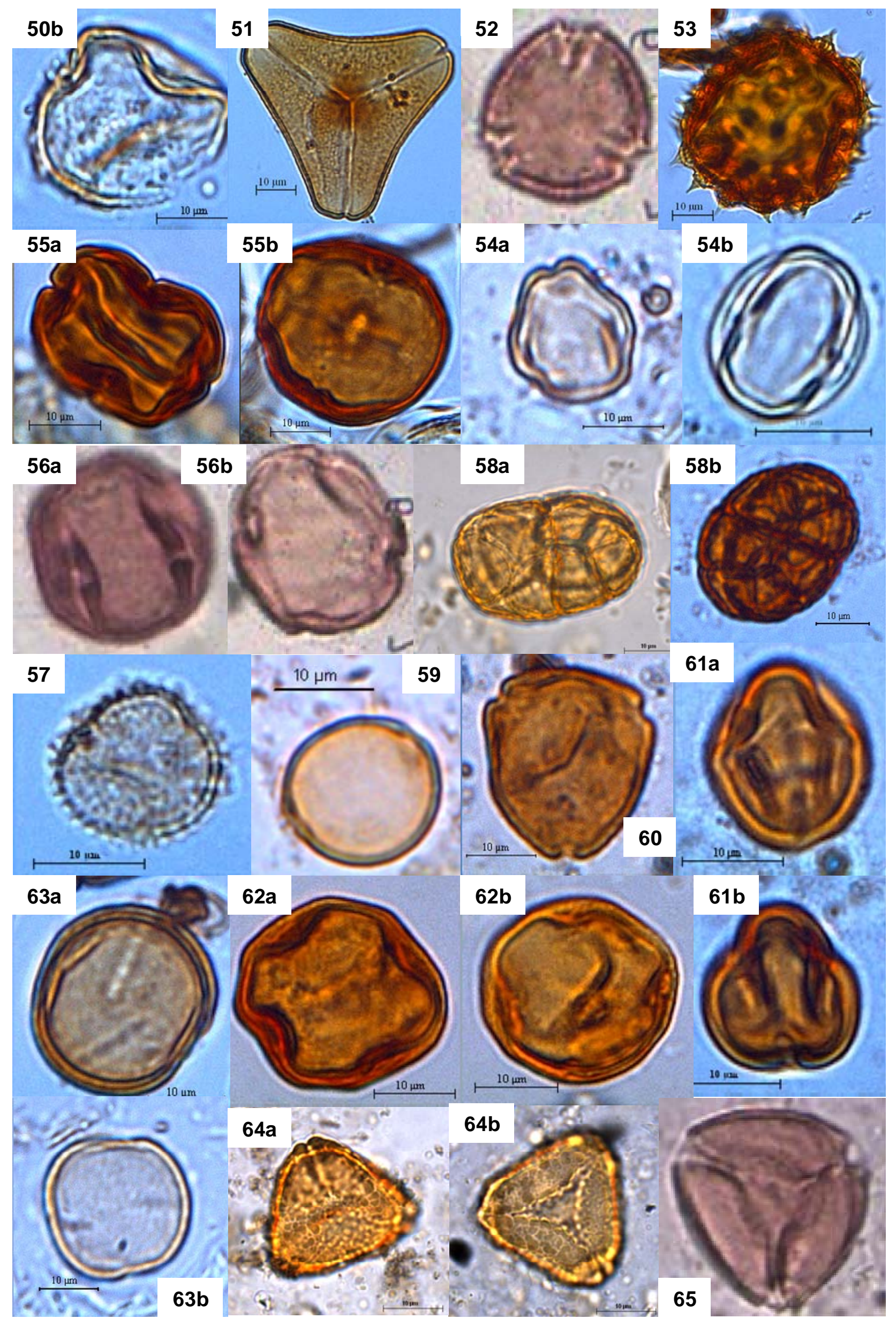


POLLEN TYPES

Colignonia

Nyctaginaceae

Periporate

(micro)reticulate

Inaperturate

Orchidaceae

Fuchsia

Onagraceae

(Tetrade)

reticulate

Triporate

psilate

Oxalis type

Oxalidaceae

Tricolpate

supra-reticulate

Bocconia

Papaveraceae

Dalea type

Papilionaceae

Pinus

Pinaceae

Piper

Piperaceae

Plantago australis

Plantaginaceae

Plantago rigida

Plantaginaceae

Plantago spp.

Zea mays

Plantaginaceae

Poaceae

Poaceae

Type 1

Type 2

Monnina

Muehlenbeckia

type

Rumex type

Panopsis

Thalictrum

Ranunculaceae

Rhamnus

Rhamnaceae

Rosaceae reticulate

Tricolpate reticulate

Vesiculate endoreticulate

Monocolpate

psilate

Periporate

verrucate

Periporate

scabr./verrucate

verrucate

Monoporate

psilate

Monoporate

psilate

Vesiculate

endoreticulate

Vesiculate

endoreticulate

Stephanocolporate

psilate

Tri/Tetracolporate

reticulate

Tri/Tetracolporate

reticulate

Triporate

Periporate

scabrate

Tricolporate

psilate

Tricolporate

verrucate/rugolate
Periporate

Periporate

foveolate
21-29 Subparamo 66

Non Arb.Pollen

28-40 LMF

Non Arb.Pollen

40-55 LMF

68

Arb.Pollen

22-28x26-38 Subparamo

Non Arb.Pollen

28-40 Paramo Non Arb.Pollen

11-16x26-35 Subparamo Non Arb.Pollen

35-45x65-85 Other 70

Arb.Pollen

5-7×8-12 LMF

Paramo

Non Arb.Pollen

24-38 Paramo 73

Non Arb.Pollen

24-38 Paramo

Non Arb.Pollen

80-120 Other 74

Non Arb.Pollen

variable Paramo 75

Non Arb.Pollen

15-23×60-80 UMF 76

Arb.Pollen

30-45x70-85 UMF 77

Arb.Pollen

25-36×35-46 Subparamo

22-30 Subparamo

Non Arb.Pollen

22-30 Paramo

Non Arb.Pollen

28-40 LMF

80

Arb.Pollen

14-20 Paramo

81

Non Arb.Pollen

13-17x15-20 UMF

Arb.Pollen

26-37 Other

Arb.Pollen 


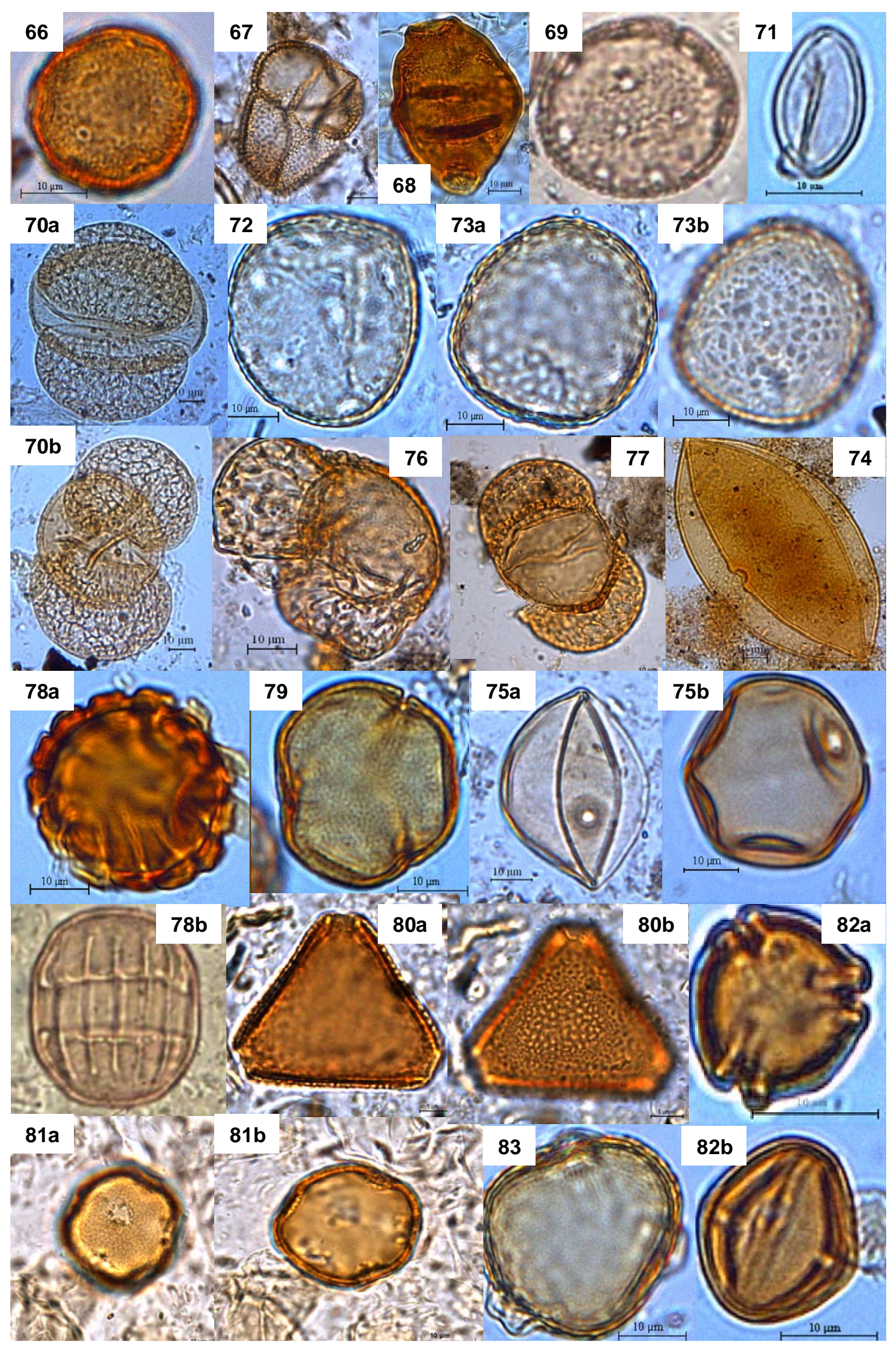




\begin{tabular}{|c|c|c|c|c|c|}
\hline Genera/Species & Family & $\begin{array}{l}\text { Aperture } \\
\text { Sculpture }\end{array}$ & $\begin{array}{c}\text { Size }(\mu \mathrm{m}) \\
\text { (equat./polar) }\end{array}$ & $\begin{array}{l}\text { Veget. Unit } \\
\text { Order }\end{array}$ & Foto \\
\hline \multicolumn{6}{|l|}{ POLLEN TYPES } \\
\hline Prunus type & Rosaceae & $\begin{array}{l}\text { Tricolporate } \\
\text { striate }\end{array}$ & $22-28 \times 28-38$ & $\begin{array}{l}\text { LMF } \\
\text { Arb.Pollen }\end{array}$ & 84 \\
\hline Arcytophyllum & Rubiaceae & $\begin{array}{l}\text { Tricolporate } \\
\text { reticulate }\end{array}$ & $25-35 \times 30-38$ & $\begin{array}{l}\text { UMF } \\
\text { Arb.Pollen }\end{array}$ & 85 \\
\hline $\begin{array}{l}\text { Spermacoce } \\
\text { (ex. Borreiria) }\end{array}$ & Rubiaceae & $\begin{array}{l}\text { Stephanoporate } \\
\text { per-reticulate }\end{array}$ & $18-25$ & $\begin{array}{l}\text { LMF } \\
\text { Arb.Pollen }\end{array}$ & 86 \\
\hline Diocedendron & Rubiaceae & $\begin{array}{l}\text { Tricolporate } \\
\text { reticulate }\end{array}$ & $10-16 \times 14-20$ & $\begin{array}{l}\text { UMF } \\
\text { Arb.Pollen }\end{array}$ & 87 \\
\hline Elaegia & Rubiaceae & $\begin{array}{l}\text { Tricolporate } \\
\text { reticulate }\end{array}$ & $17-23 \times 20-26$ & $\begin{array}{l}\text { UMF } \\
\text { Arb.Pollen }\end{array}$ & 88 \\
\hline Farmarea & Rubiaceae & $\begin{array}{l}\text { Tricolporate } \\
\text { per-reticulate }\end{array}$ & $28-38$ & $\begin{array}{l}\text { UMF } \\
\text { Arb.Pollen }\end{array}$ & 89 \\
\hline Joosia & Rubiaceae & $\begin{array}{l}\text { Tricolporate } \\
\text { reticulate }\end{array}$ & $16-24 \times 26-45$ & $\begin{array}{l}\text { UMF } \\
\text { Arb.Pollen }\end{array}$ & 90 \\
\hline Ladenbergia & Rubiaceae & $\begin{array}{l}\text { Tricolporate } \\
\text { reticulate }\end{array}$ & $15-22 \times 19-26$ & $\begin{array}{l}\text { UMF } \\
\text { Arb.Pollen }\end{array}$ & 91 \\
\hline Palicoura & Rubiaceae & $\begin{array}{l}\text { Inaperturate } \\
\text { per-reticulate }\end{array}$ & $50-65$ & $\begin{array}{l}\text { Subparamo } \\
\text { Arb.Pollen }\end{array}$ & 92 \\
\hline Zanthroxylum & Rutaceae & $\begin{array}{l}\text { Tricolporate } \\
\text { striate/reticulate }\end{array}$ & $18-23 \times 22-29$ & $\begin{array}{l}\text { UMF } \\
\text { Arb.Pollen }\end{array}$ & \\
\hline Dodonaea & Sapindaceae & $\begin{array}{l}\text { Tricolporate } \\
\text { scabrate }\end{array}$ & $25-35$ & $\begin{array}{l}\text { LMF } \\
\text { Arb.Pollen }\end{array}$ & 93 \\
\hline Escallonia type & Saxifragaceae & $\begin{array}{l}\text { Tricolporate } \\
\text { reticulate }\end{array}$ & $11-14 \times 13-16$ & $\begin{array}{l}\text { LMF } \\
\text { Arb.Pollen }\end{array}$ & 94 \\
\hline Calceolaria type & Scrophulariaceae & $\begin{array}{l}\text { Stephanocolporate } \\
\text { psilate/scabrate }\end{array}$ & $9-13 \times 11-16$ & $\begin{array}{l}\text { Subparamo } \\
\text { Non Arb.Pollen }\end{array}$ & 95 \\
\hline Smilax & Smilacaceae & $\begin{array}{l}\text { Monocolpate } \\
\text { reticulate }\end{array}$ & $14-17$ & $\begin{array}{l}\text { LMF } \\
\text { Non Arb.Pollen }\end{array}$ & \\
\hline Solanum & Solanaceae & $\begin{array}{l}\text { Tricolporate } \\
\text { psilate }\end{array}$ & $14-20 \times 18-25$ & $\begin{array}{l}\text { LMF } \\
\text { Arb.Pollen }\end{array}$ & 96,97 \\
\hline Styrax & Styracaceae & $\begin{array}{l}\text { Tricolporate } \\
\text { scabrate }\end{array}$ & $25-35$ & $\begin{array}{l}\text { UMF } \\
\text { Arb.Pollen }\end{array}$ & 98 \\
\hline
\end{tabular}




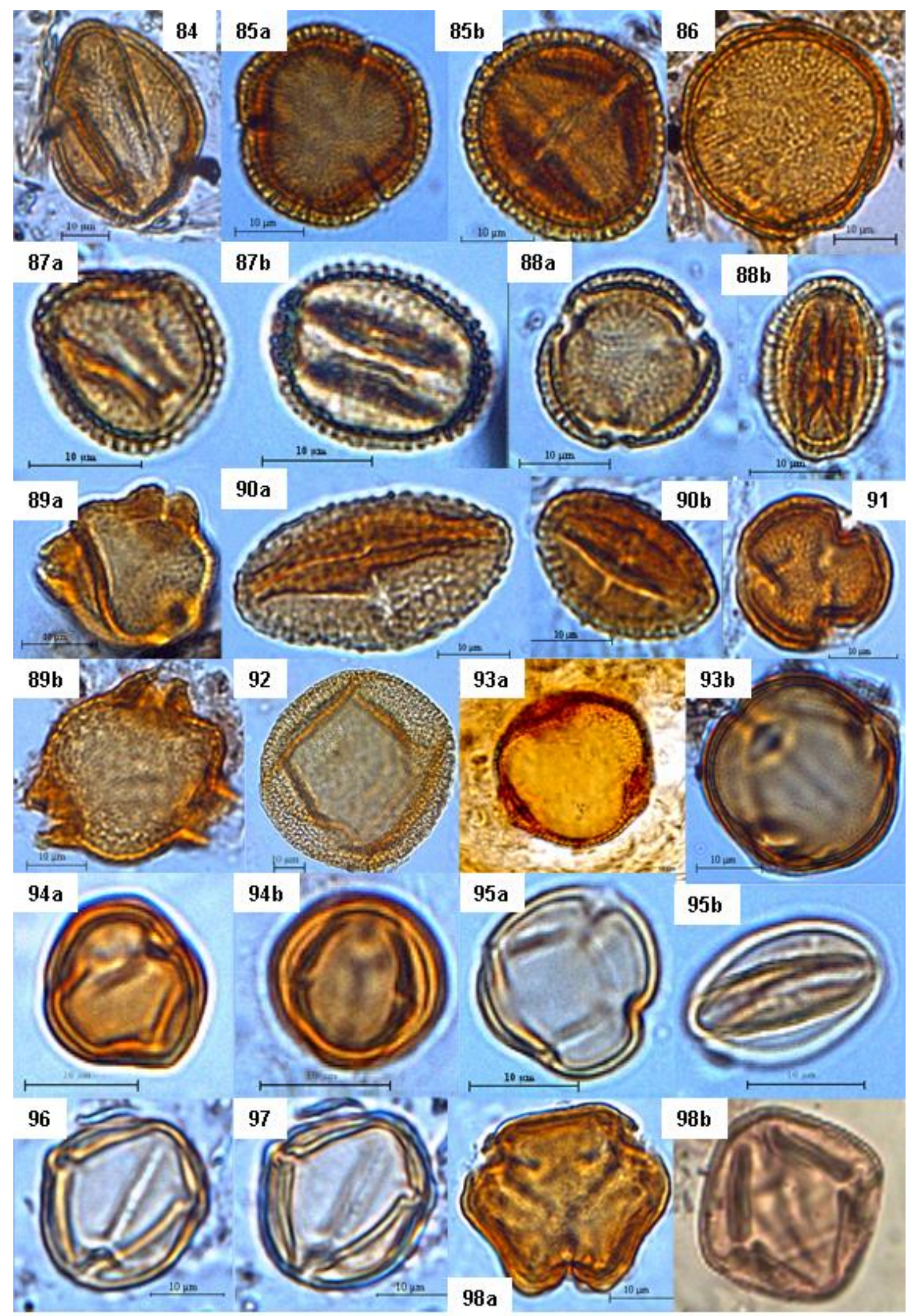


POLLEN TYPES

Symplocos

bogotensis type

Symplocos

coriacea type

Symplocos

peruviana type

Symplocos type 1 Symplocaceae

Symplocos type 2 Symplocaceae

Symplocos type 3 Symplocaceae

Symplocos type 4 Symplocaceae

Symplocos type 5 Symplocaceae

Ternstroemia Theaceae

Daphnopsis Thymelaeaceae

Heliocarpus Tiliaceae

Celtis Ulmaceae

Trema Ulmaceae

Valeriana type 1 Valerianaceae

Valeriana type 2 Valerianaceae

Viola type Violaceae

Xyris Xyridaceae

Tetrade type Unknown

Type $1 \quad$ Unknown

Type $2 \quad$ Unknown

Type $3 \quad$ Unknown

Type $4 \quad$ Unknown

Type $5 \quad$ Unknown

Type $6 \quad$ Unknown

Type $7 \quad$ Unknown

Type 8
Triporate

bacculate/clavate

Triporate

psilate (rugolate)

Triporate

psilate/scabrate

Triporate

psilate

Triporate

psilate/scabrate

Triporate

bacculate/clavate

Diporate

psilate

Diporate

bacculate/clavate

Tricolporate

psilate

Periporate

reticulate

Tricolporate

reticulate

Triporate

psilate

Diporate

psilate/scabrate

Tricolporate

echinate

Tricolporate

(micro)echinate

Tricolporate

psilate

Monocolpate

reticulate

Tricolpate (Tetrade)

psilate

Tricolporate

reticulate

Tricolporate

reticulate

Tricolporate

reticulate

Pericolpate

scabrate

Periporate

reticulate

Pericolpate

reticulate

Tricolporate

reticulate

Tricolporate

foveolate
21-26 UMF

99

24-31 UMF

Arb.Pollen

26-35 UMF

Arb.Pollen

24-35 UMF

Arb.Pollen

38-50 UMF

Arb.Pollen

28-40 UMF

Arb.Pollen

18-28 UMF

Arb.Pollen

19-32 UMF

Arb.Pollen

100

16-20x22-28 Subparamo 103

26-34 Subparamo

104

Non Arb.Pollen

16-24×25-38 LMF

Arb.Pollen

21-27

LMF

Arb.Pollen

13-17x15-20 LMF

Arb.Pollen

42-55 Paramo

Non Arb.Pollen

45-58 Paramo

Non Arb.Pollen

25×31 Subparamo

Non Arb.Pollen

36-54 Subparamo

Non Arb.Pollen

20-28 Subparamo

Non Arb.Pollen

13-18x16-22 Unknown

Unknown

19-24x23-29 Unknown

Unknown

25-31×30-42 Unknown

Unknown

31-35 Unknown

Unknown

30-36 Unknown

Unknown

28-44 Unknown

Unknown

23-31x29-40 Unknown

Unknown

24-29x27-33 Unknown

Unknown 

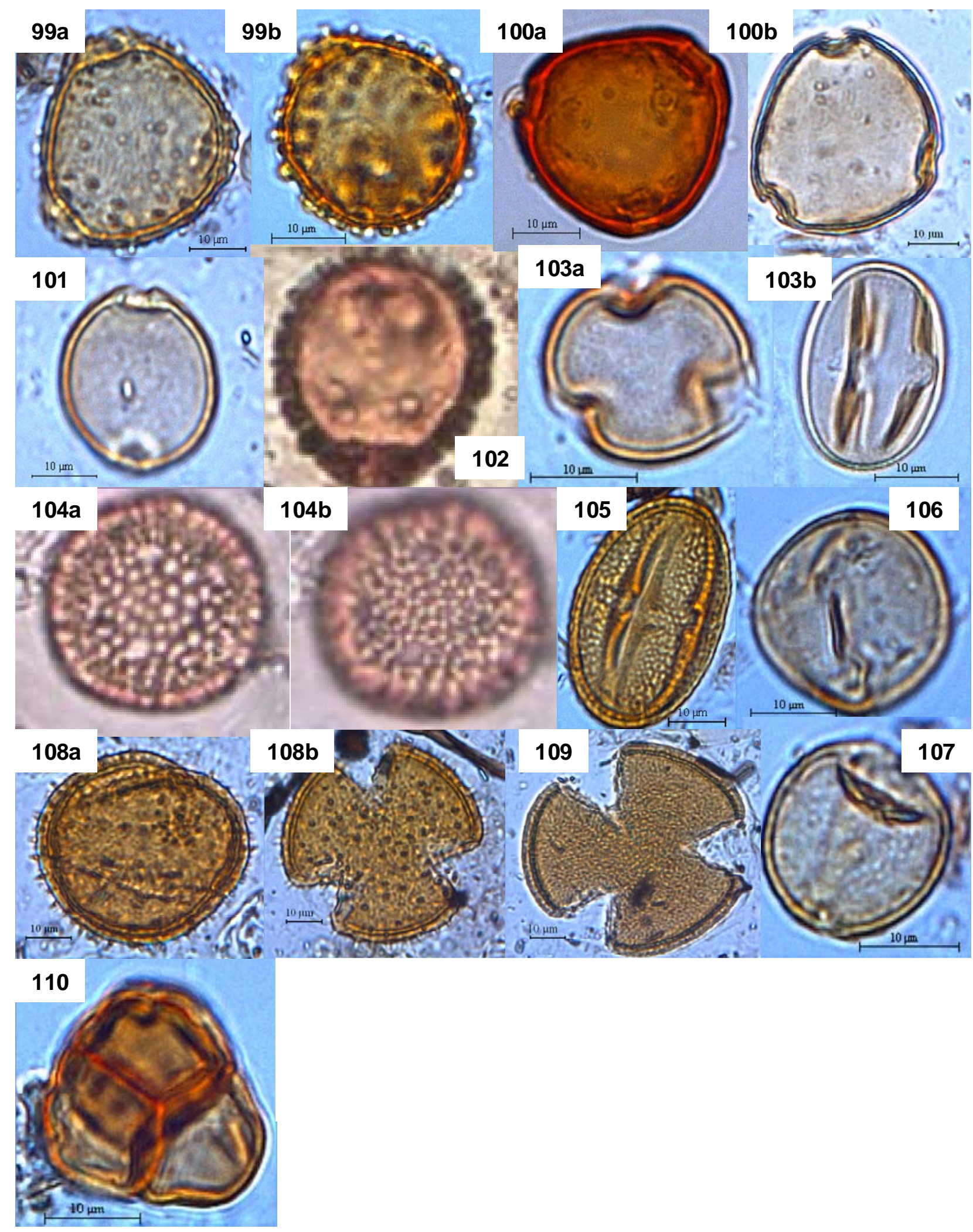


\begin{tabular}{|c|c|c|c|c|}
\hline Genera/Species & Family & $\begin{array}{l}\text { Aperture } \\
\text { Sculpture }\end{array}$ & $\begin{array}{c}\text { Size }(\mu \mathrm{m}) \\
\text { (polarlequat.) }\end{array}$ & Foto \\
\hline \multicolumn{5}{|l|}{ SPORE TYPES } \\
\hline Blechnum auratum type & Blechnaceae & $\begin{array}{l}\text { Monolete } \\
\text { striate (rugulae) }\end{array}$ & $35-45 \times 23-33$ & 111 \\
\hline Blechnum spp. & Blechnaceae & $\begin{array}{l}\text { Monolete } \\
\text { psilate }\end{array}$ & $55-80 \times 40-65$ & \\
\hline Polystichum nudicaule & Dryopteridaceae & $\begin{array}{l}\text { Monolete } \\
\text { echinate }\end{array}$ & $34-45 \times 24-33$ & 112 \\
\hline Sticherus & Gleicheniaceae & $\begin{array}{l}\text { Monolete } \\
\text { psilate }\end{array}$ & $36-50 \times 25-38$ & 113 \\
\hline Isoetes & Isoetaceae & $\begin{array}{l}\text { Monolete } \\
\text { psilate }\end{array}$ & $18-30 \times 35-60$ & 114 \\
\hline Elaphoglossum ciliatum type & Lomariopsidaceae & $\begin{array}{l}\text { Monolete } \\
\text { psilate }\end{array}$ & $32-40 \times 20-30$ & \\
\hline Monolete clavate & Unknown & $\begin{array}{l}\text { Monolete } \\
\text { clavate }\end{array}$ & variable & \\
\hline Monolete echinate & Unknown & $\begin{array}{l}\text { Monolete } \\
\text { echinate }\end{array}$ & variable & \\
\hline Monolete psilate type 1 & Unknown & $\begin{array}{l}\text { Monolete } \\
\text { psilate }\end{array}$ & $35-65 \times 25-40$ & 115 \\
\hline Monolete psilate type 2 & Unknown & $\begin{array}{l}\text { Monolete } \\
\text { psilate }\end{array}$ & $65-90 \times 35-60$ & 116 \\
\hline Monolete reticulate & Unknown & $\begin{array}{l}\text { Monolete } \\
\text { reticulate }\end{array}$ & variable & \\
\hline Monolete verrucate & Unknown & $\begin{array}{l}\text { Monolete } \\
\text { verrucate }\end{array}$ & variable & 117 \\
\hline Jamesonia & Adiantaceae & $\begin{array}{l}\text { Trilete } \\
\text { verrucate/rugulate }\end{array}$ & $55-80$ & 118 \\
\hline Alsophila type & Cyatheaceae & $\begin{array}{l}\text { Trilete } \\
\text { (micro)reticulate }\end{array}$ & $35-45$ & \\
\hline Cyathea bipinnatifida type & Cyatheaceae & $\begin{array}{l}\text { Trilete } \\
\text { psilate }\end{array}$ & $32-43$ & \\
\hline Cyathea conjugata type & Cyatheaceae & $\begin{array}{l}\text { Trilete } \\
\text { microechinate }\end{array}$ & $30-42$ & 119 \\
\hline Cyathea hemitelia type & Cyatheaceae & $\begin{array}{l}\text { Trilete } \\
\text { psilate }\end{array}$ & $32-45$ & 120 \\
\hline Cyathea horrida type & Cyatheaceae & $\begin{array}{l}\text { Trilete } \\
\text { psilate }\end{array}$ & $35-50$ & 121 \\
\hline Cyathea nephela type & Cyatheaceae & $\begin{array}{l}\text { Trilete } \\
\text { psilate/striate }\end{array}$ & $45-60$ & 122 \\
\hline Cyathea peladensis type & Cyatheaceae & $\begin{array}{l}\text { Trilete } \\
\text { verrucate }\end{array}$ & $27-36$ & 123 \\
\hline Cyathea psilate form type & Cyatheaceae & $\begin{array}{l}\text { Trilete } \\
\text { psilate }\end{array}$ & $30-45$ & 124 \\
\hline Cyathea verrucate form type & Cyatheaceae & $\begin{array}{l}\text { Trilete } \\
\text { verrucate }\end{array}$ & $45-60$ & 125 \\
\hline Pterium arachnoideum & Dennstaedtiaceae & $\begin{array}{l}\text { Trilete } \\
\text { verrucate/rugulate }\end{array}$ & $45-60$ & \\
\hline Dicksonia sellowiana & Dicksoniaceae & $\begin{array}{l}\text { Trilete } \\
\text { verrucate }\end{array}$ & $42-55$ & \\
\hline Lellingeria & Grammitidaceae & $\begin{array}{l}\text { Trilete } \\
\text { clavate }\end{array}$ & $25-33$ & 126 \\
\hline
\end{tabular}




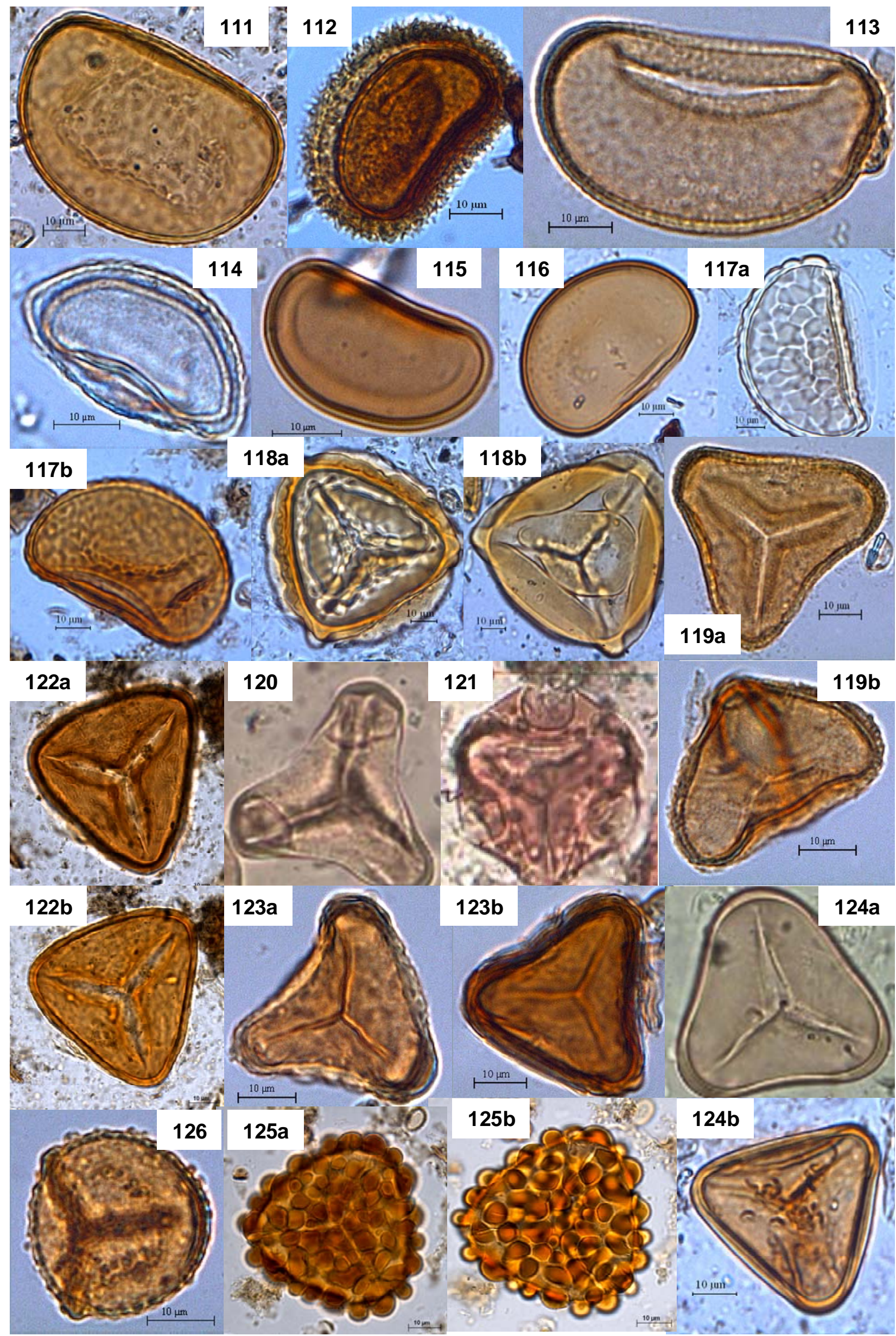




\begin{tabular}{|c|c|c|c|c|}
\hline Genera/Species & Family & $\begin{array}{l}\text { Aperture } \\
\text { Sculpture }\end{array}$ & $\begin{array}{c}\text { Size }(\mu \mathrm{m}) \\
\text { (polar/equat.) }\end{array}$ & Foto \\
\hline \multicolumn{5}{|l|}{ SPORE TYPES } \\
\hline Grammites & Grammitidaceae & $\begin{array}{l}\text { Trilete } \\
\text { verrucate }\end{array}$ & $30-45$ & 127 \\
\hline Terpsichlore & Grammitidaceae & $\begin{array}{l}\text { Trilete } \\
\text { verrucate }\end{array}$ & $30-38$ & \\
\hline Hymenophyllum & Hymenophyllaceae & $\begin{array}{l}\text { Trilete } \\
\text { scabrate/verrucate }\end{array}$ & $55-75$ & 128 \\
\hline Lycopodium clavatum type & Lycopodiaceae & $\begin{array}{l}\text { Trilete } \\
\text { reticulate }\end{array}$ & $35-48$ & 129 \\
\hline Lycopodium curvatum type & Lycopodiaceae & $\begin{array}{l}\text { Trilete } \\
\text { fossulate }\end{array}$ & $48-65$ & 130 \\
\hline Lycopodiella cernuum type & Lycopodiaceae & $\begin{array}{l}\text { Trilete } \\
\text { fossulate/exospore }\end{array}$ & $30-42$ & 131 \\
\hline Huperzia & Lycopodiaceae & $\begin{array}{l}\text { Trilete } \\
\text { foveolate }\end{array}$ & $45-60$ & 132 \\
\hline Osmunda & Osmundaceae & $\begin{array}{l}\text { Trilete } \\
\text { verrucate }\end{array}$ & $75-90$ & 133 \\
\hline Pecluma eurybasis & Polypodaiceae & $\begin{array}{l}\text { Trilete } \\
\text { verrucate }\end{array}$ & $37-45$ & \\
\hline Trilete scrabrate & Unknown & $\begin{array}{l}\text { Trilete } \\
\text { scrabrate }\end{array}$ & variable & \\
\hline Trilete echinate & Unknown & $\begin{array}{l}\text { Trilete } \\
\text { echinate }\end{array}$ & variable & 134 \\
\hline Trilete exospore type & Unknown & $\begin{array}{l}\text { Trilete } \\
\text { variable (exospore) }\end{array}$ & $30-38$ & 135 \\
\hline Trilete psilate & Unknown & $\begin{array}{l}\text { Trilete } \\
\text { psilate }\end{array}$ & variable & 136 \\
\hline Trilete reticulate & Unknown & $\begin{array}{l}\text { Trilete } \\
\text { reticulate }\end{array}$ & variable & \\
\hline Trilete verrucate & Unknown & $\begin{array}{l}\text { Trilete } \\
\text { verrucate }\end{array}$ & variable & \\
\hline Sphagnum & Sphagnaceae & $\begin{array}{l}\text { Trilete } \\
\text { psilate/verrucate }\end{array}$ & $40-55$ & 137 \\
\hline Cercophora type & Ascospores & & $21-26$ & 138 \\
\hline Podospora type & Ascospores & & $32-40$ & 139 \\
\hline Sodaria type & Ascospores & & $33-45$ & 140 \\
\hline Sporomiella type & Ascospores & & $17-23$ & 141 \\
\hline \multicolumn{5}{|l|}{ ALGAE } \\
\hline Botryococcus braunii & Chlorophyceae & & variable & 142 \\
\hline
\end{tabular}




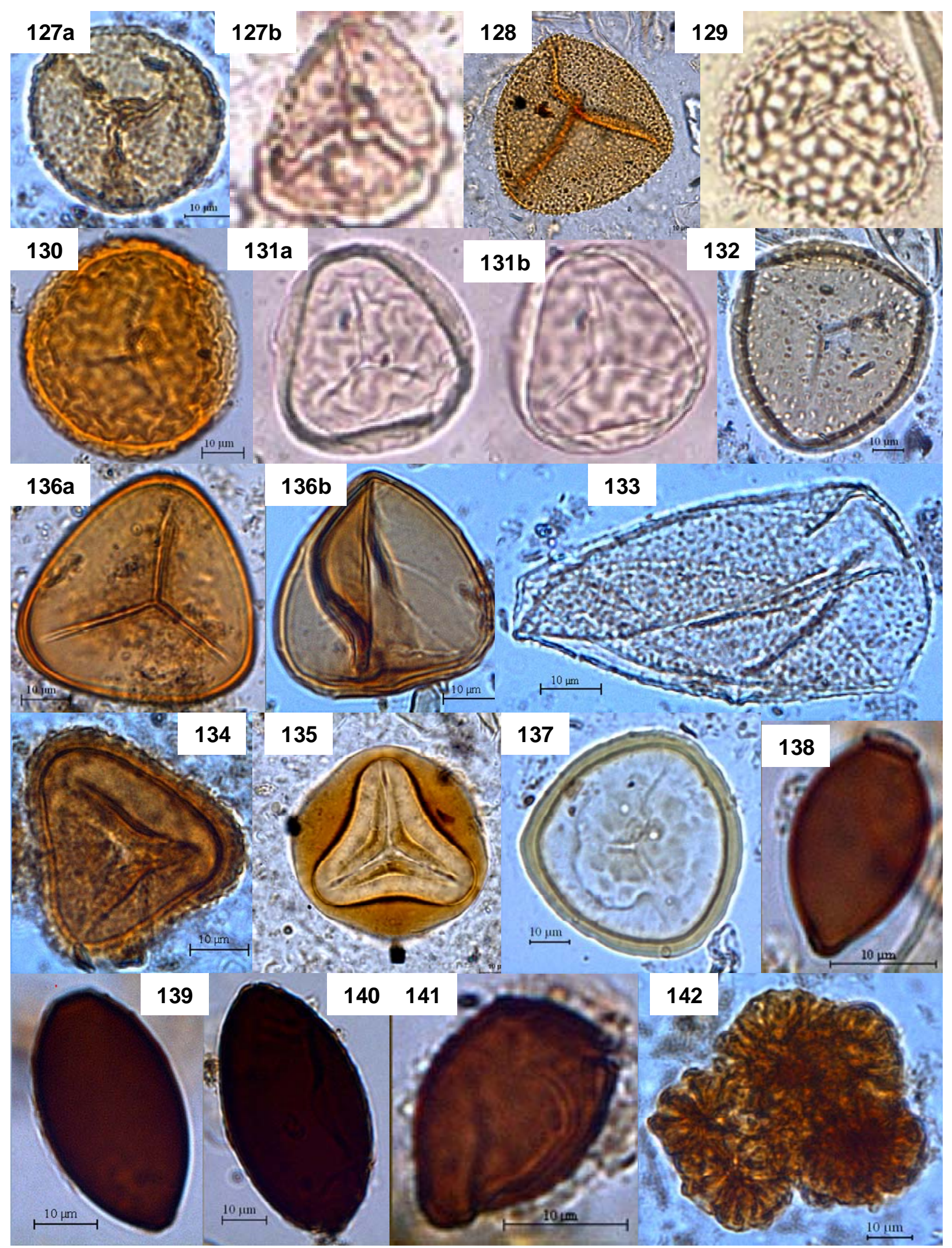


Appendix B - Complete records 


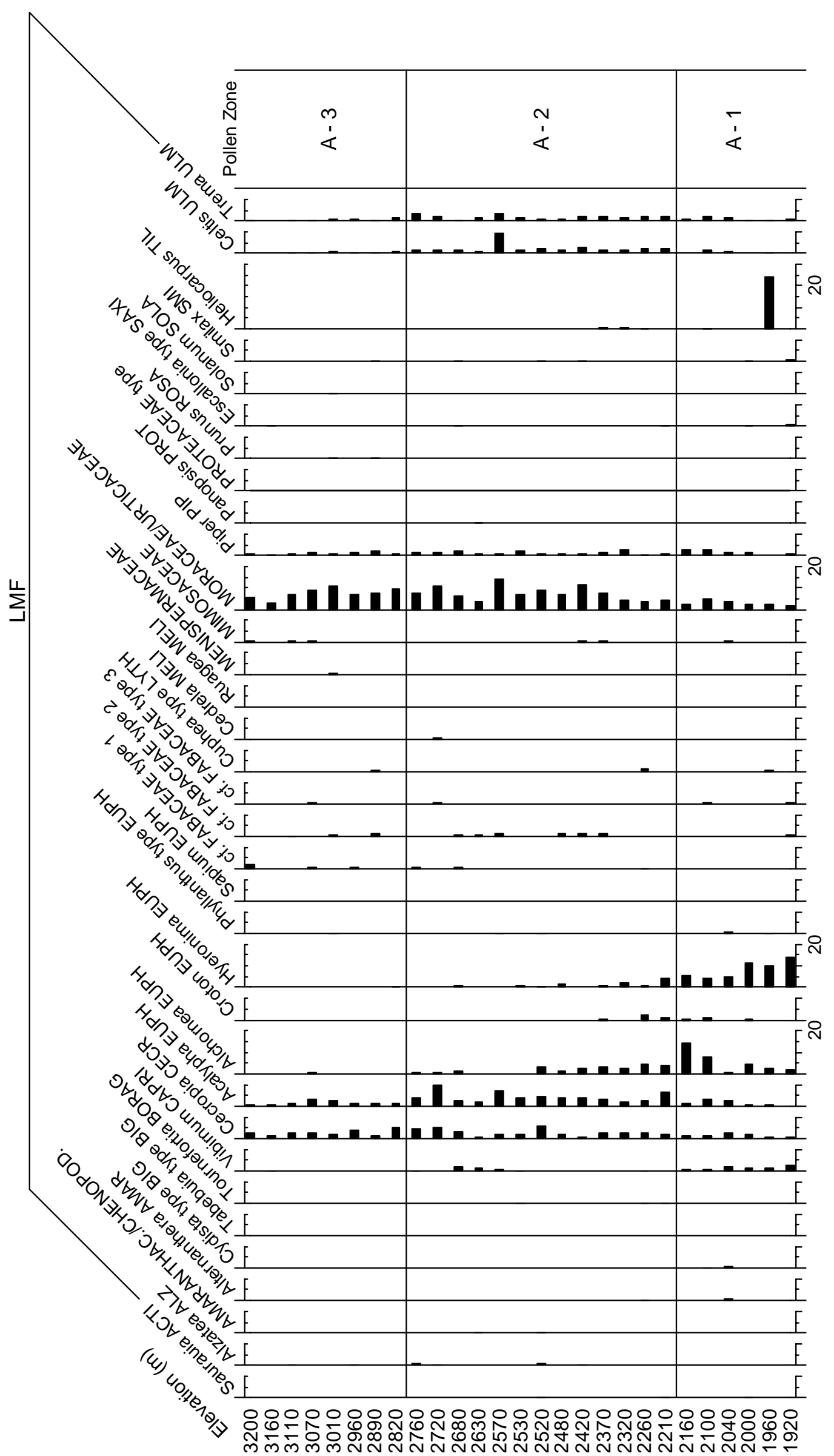

Transect A (ECSF) of modern pollen rain (1) 


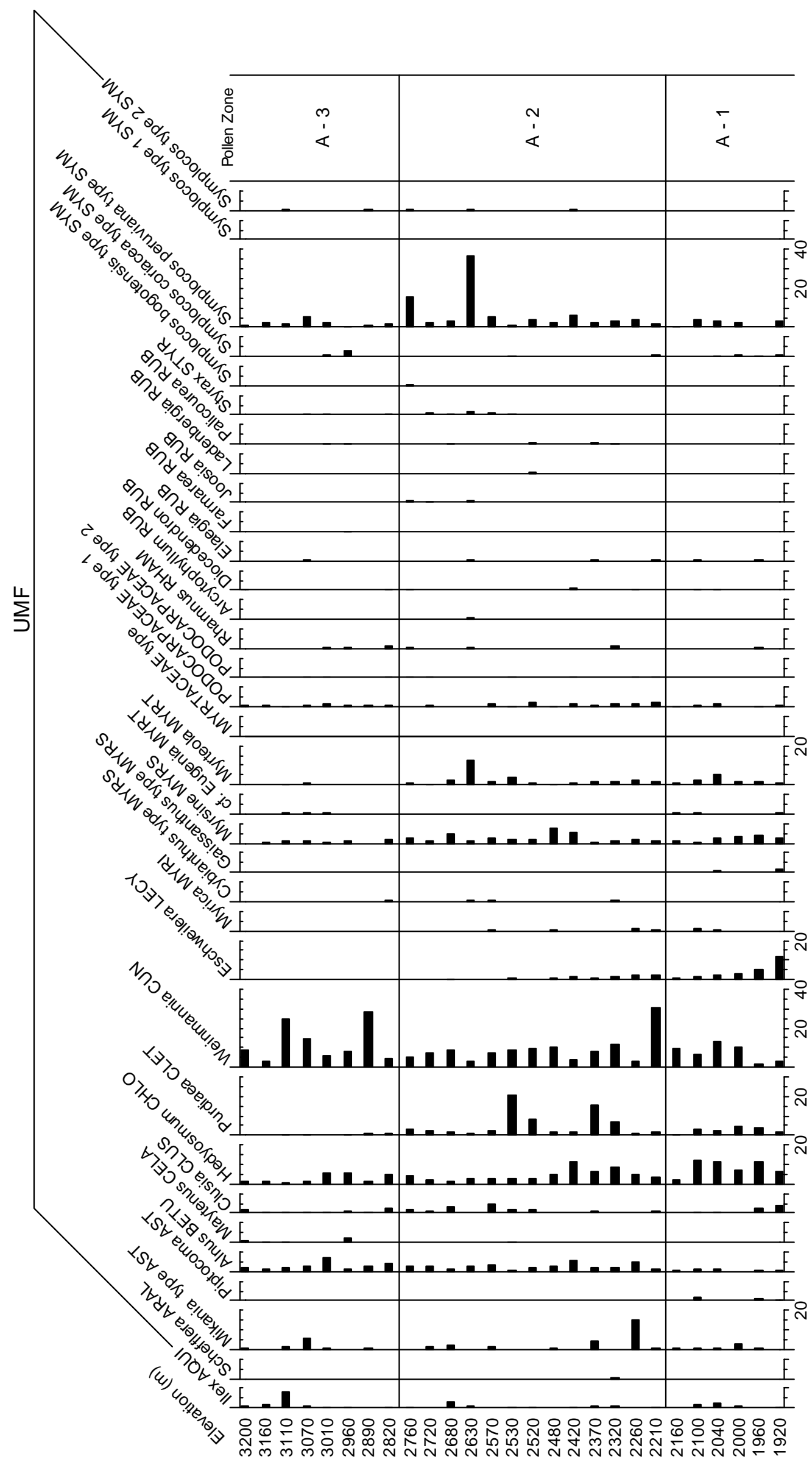

Transect A (ECSF) of modern pollen rain (2) 


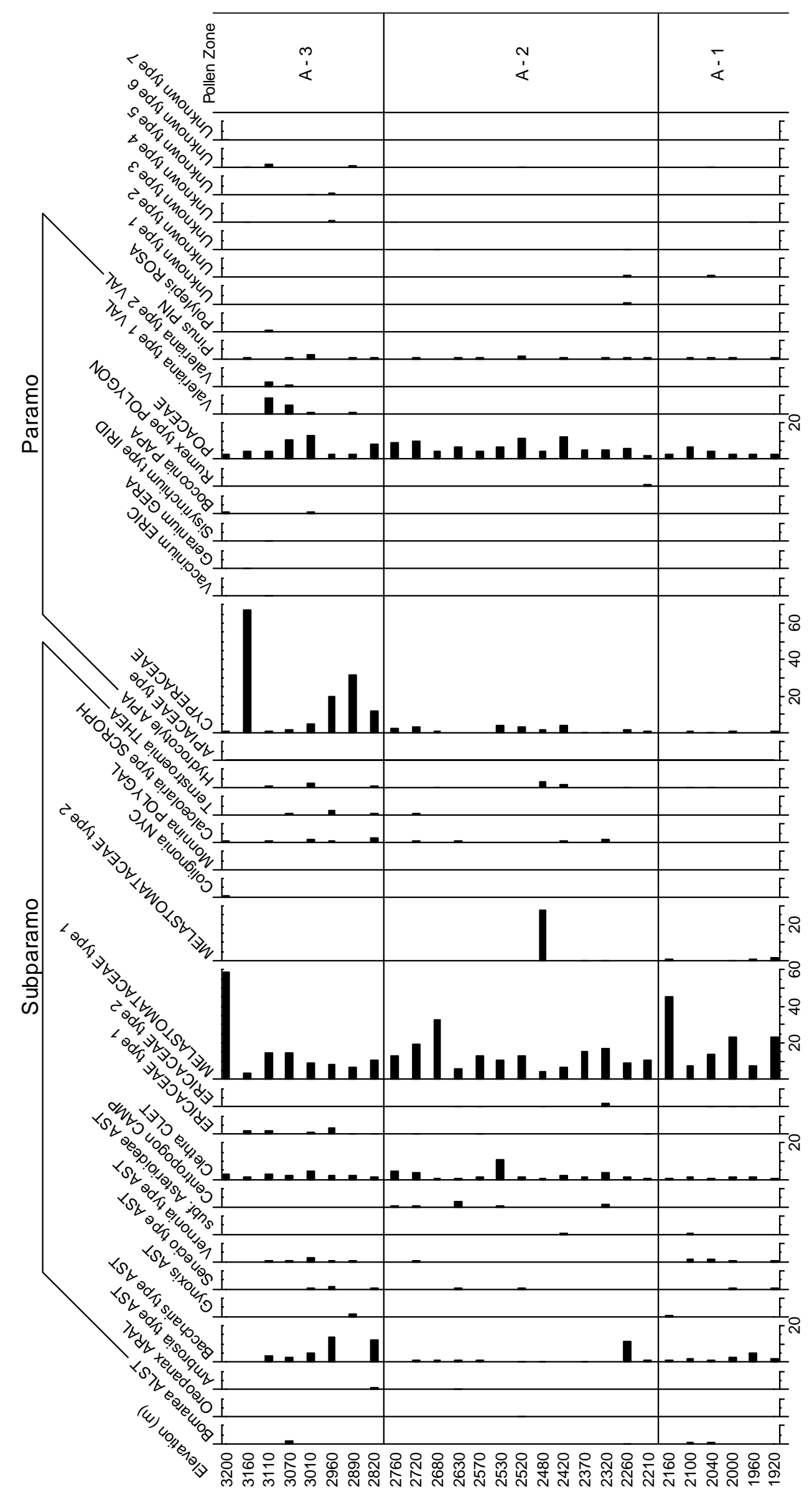

Transect A (ECSF) of modern pollen rain (3) 


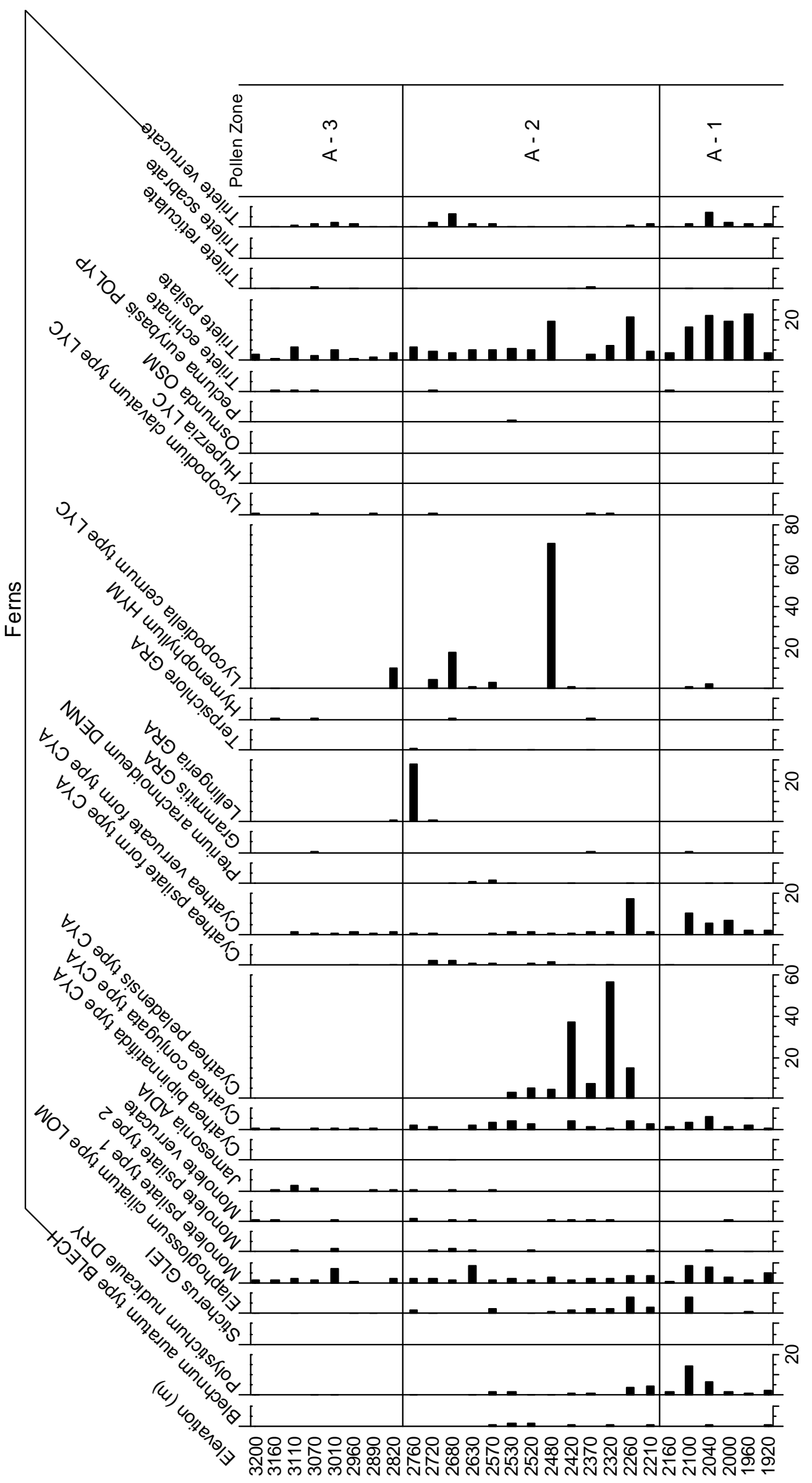

Transect A (ECSF) of modern pollen rain (4) 


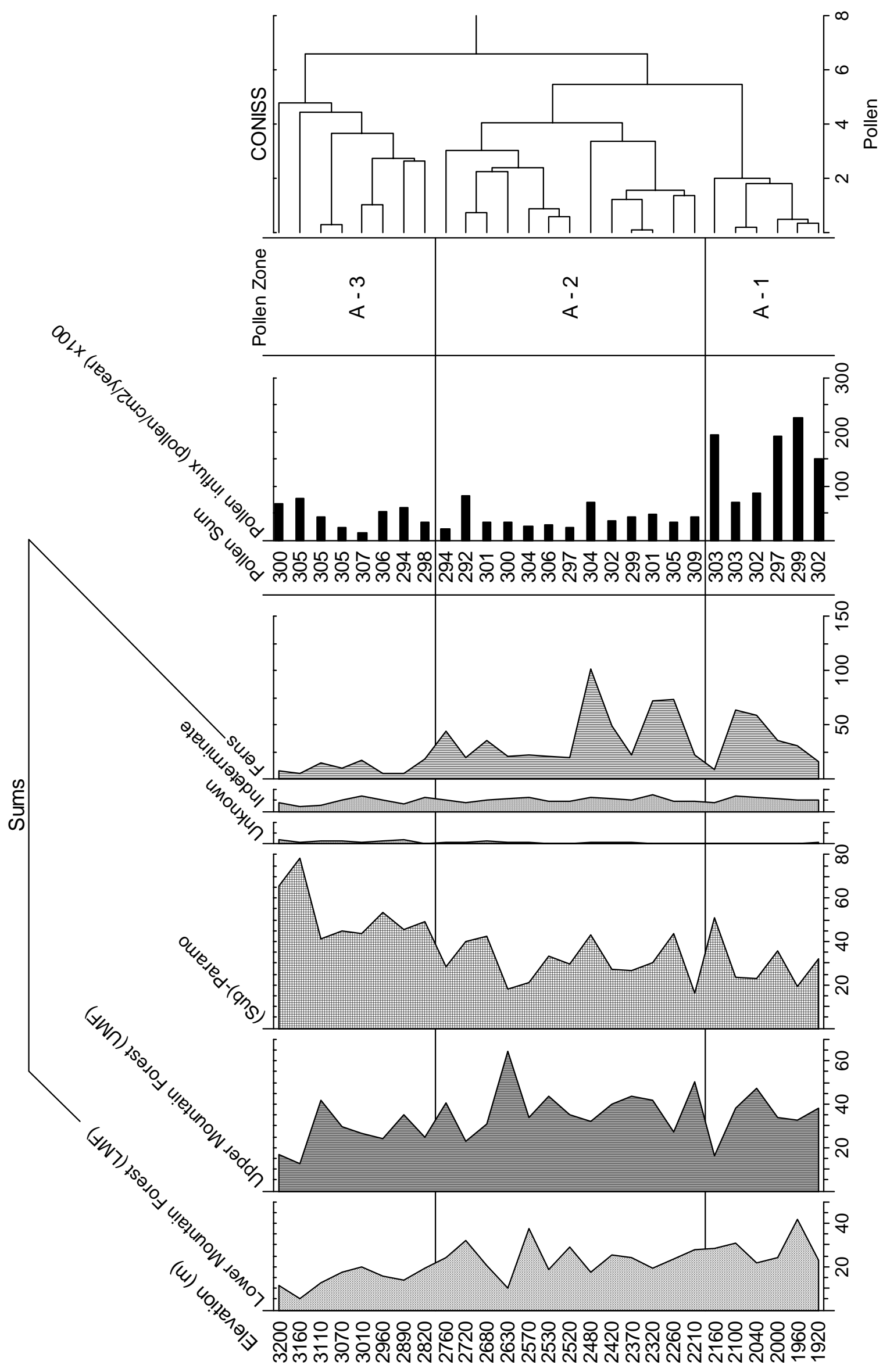




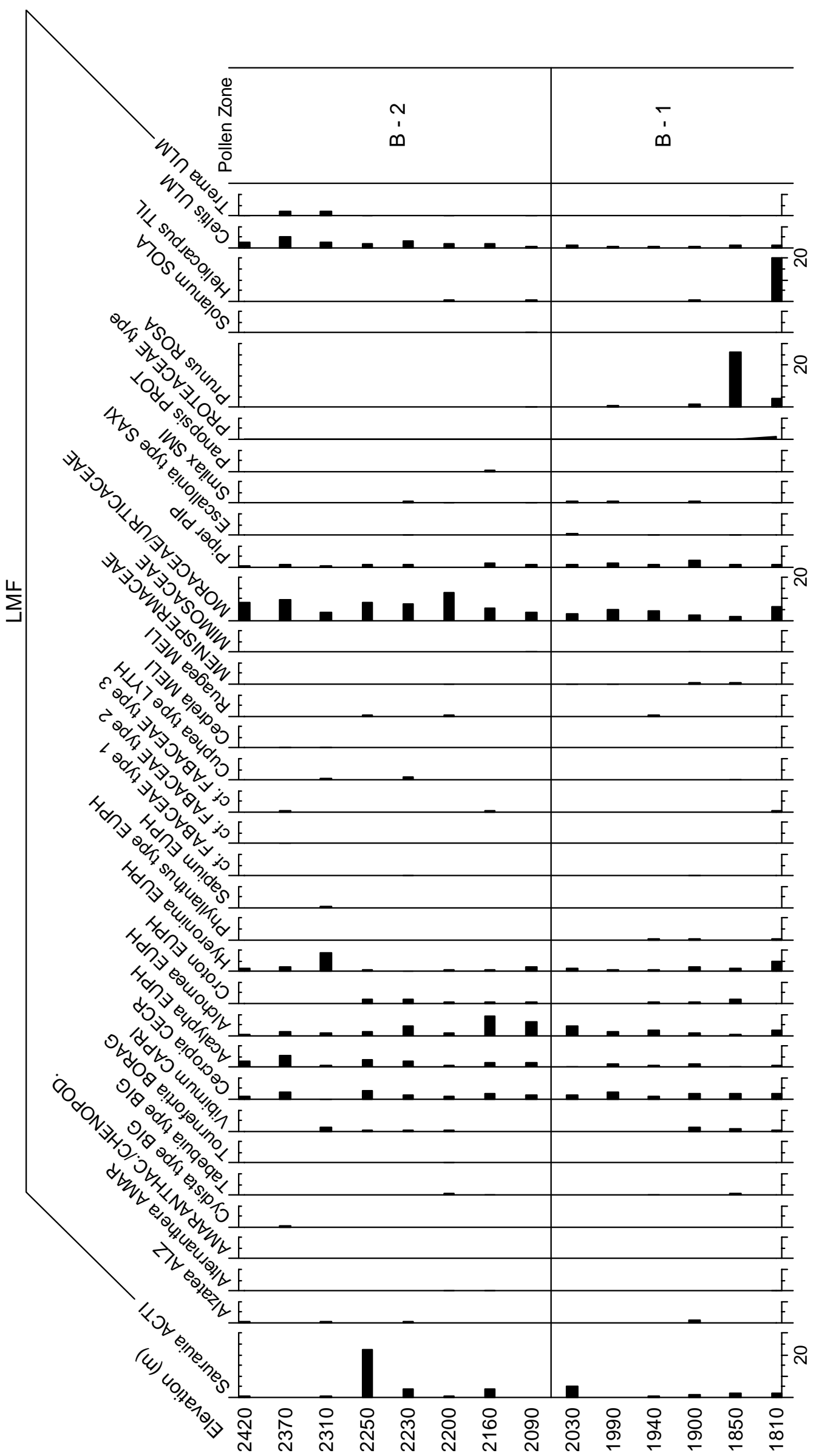

Transect B (ECSF) of modern pollen rain (1) 


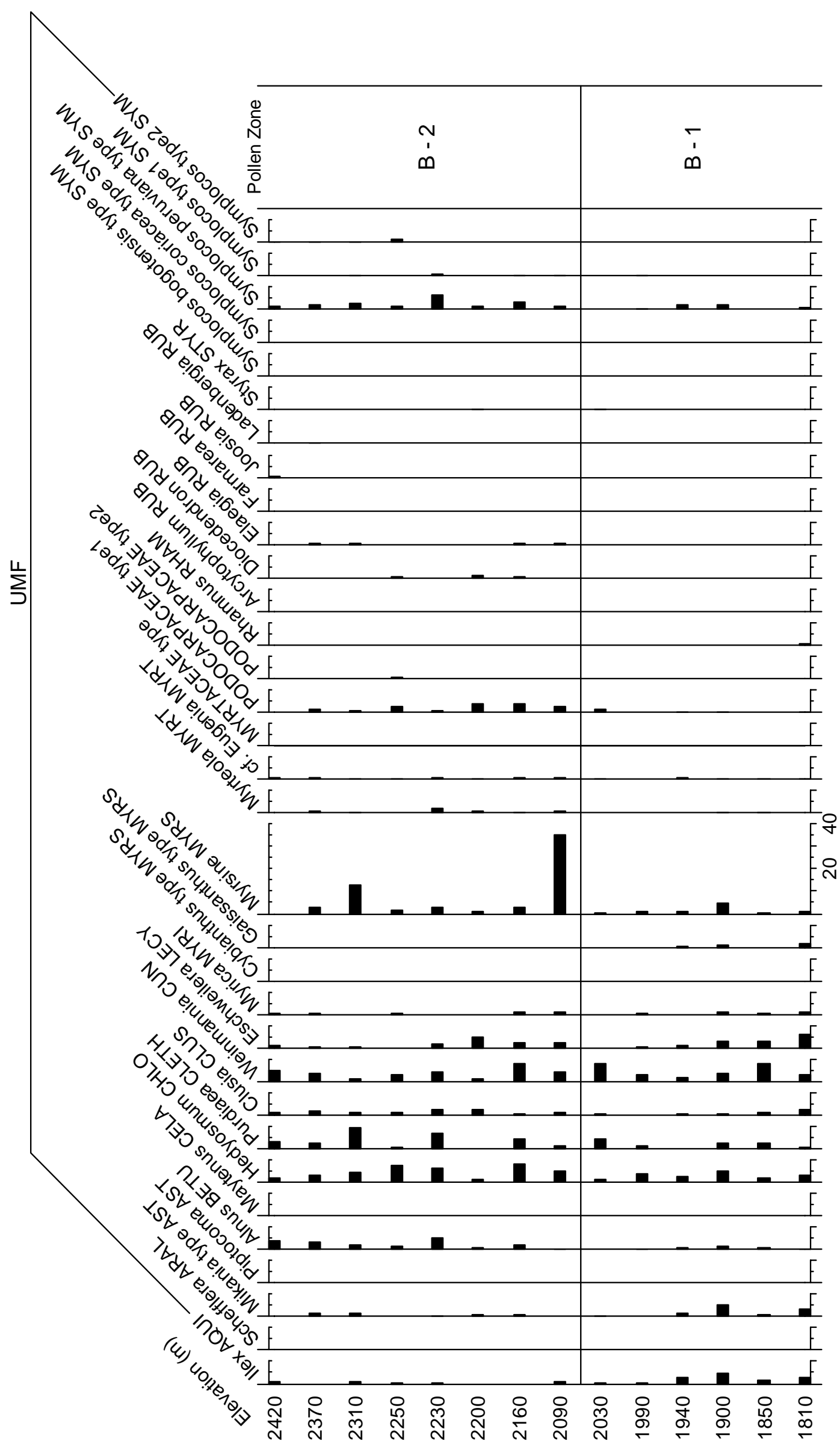

Transect B (ECSF) of modern pollen rain (2) 


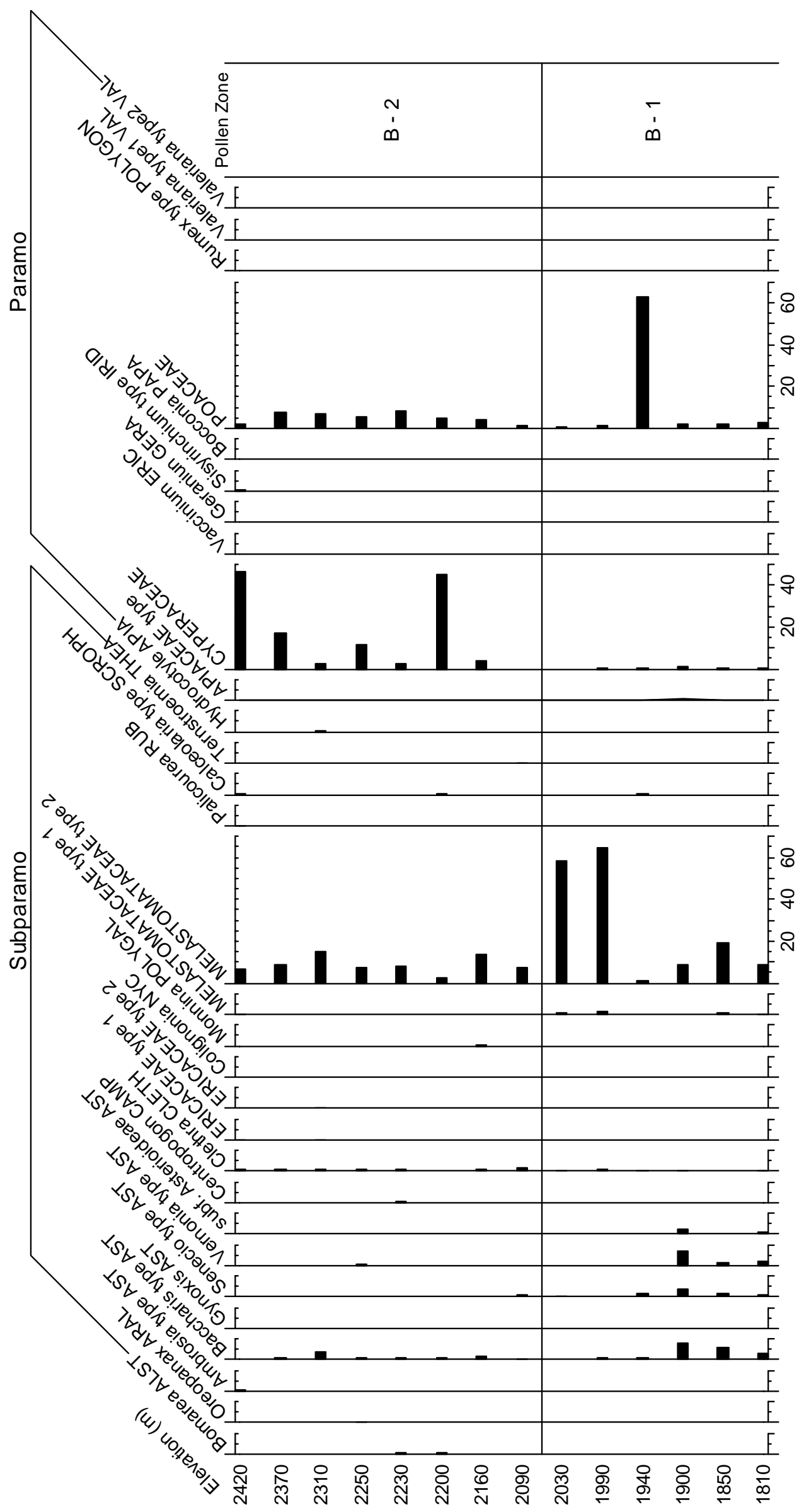

Transect B (ECSF) of modern pollen rain (3) 


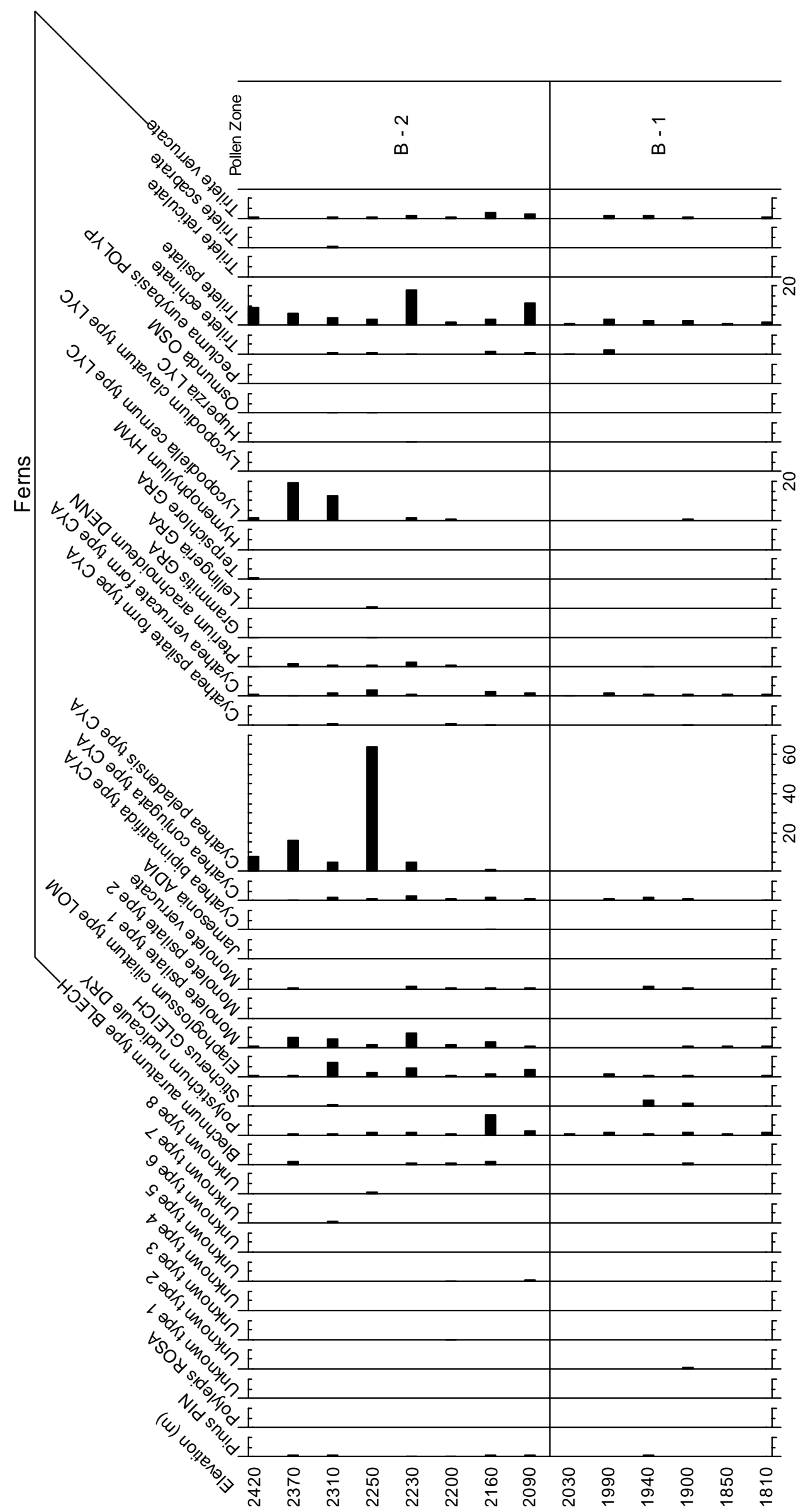

Transect B (ECSF) of modern pollen rain (4) 


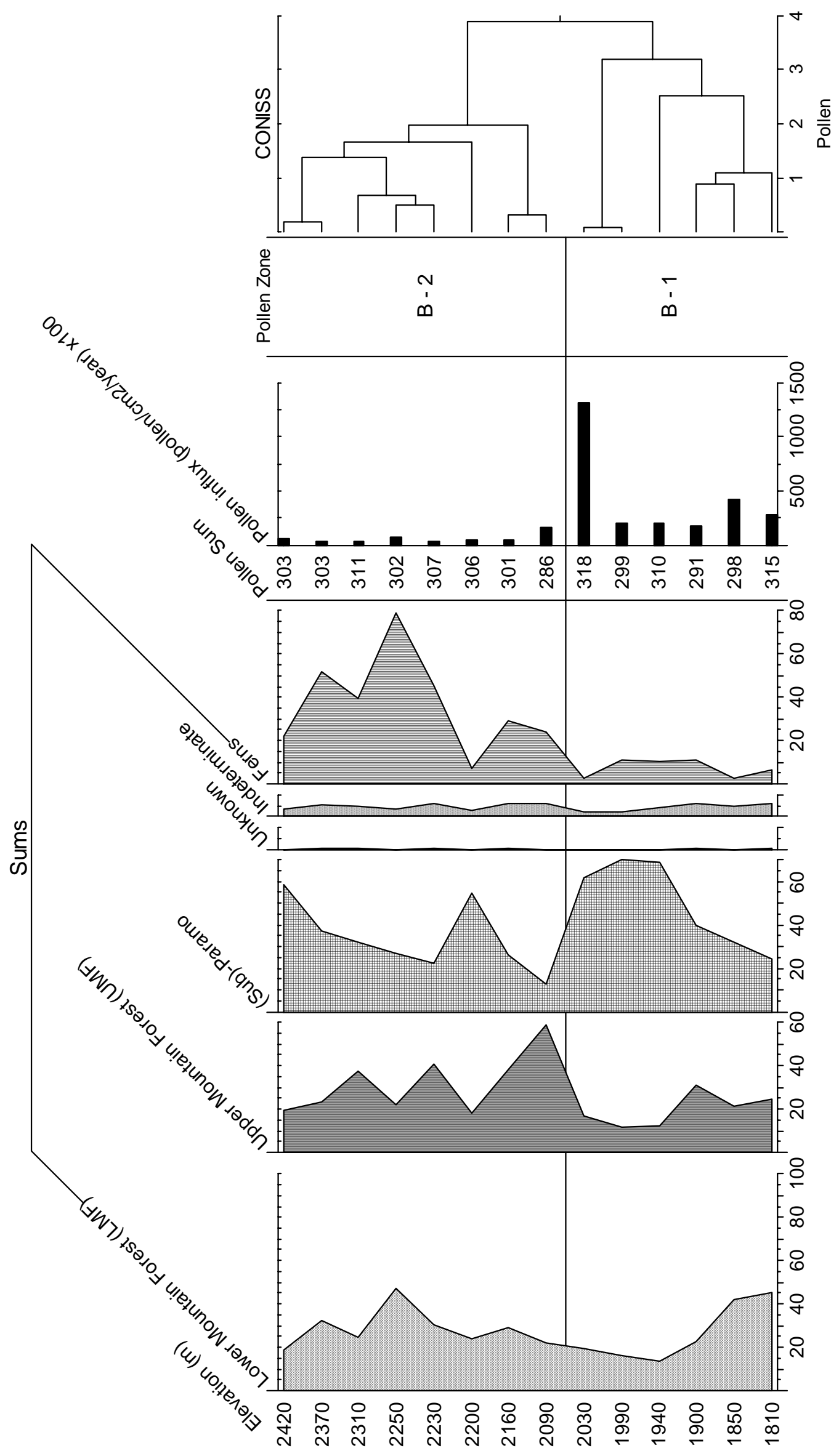

Transect B (ECSF) of modern pollen rain (5) 


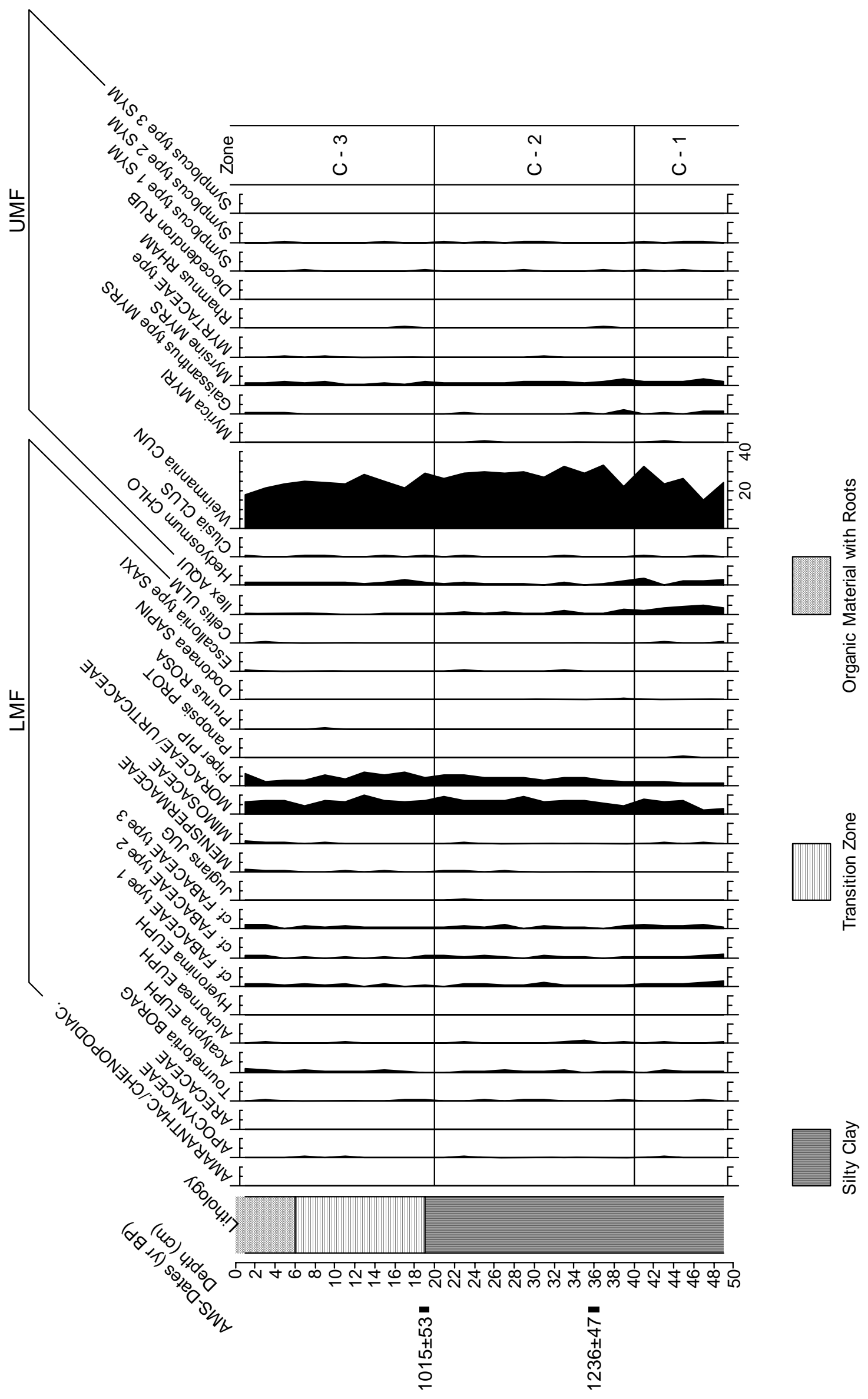

Complete record of ECSF-Cerro de Consuelo (1) 


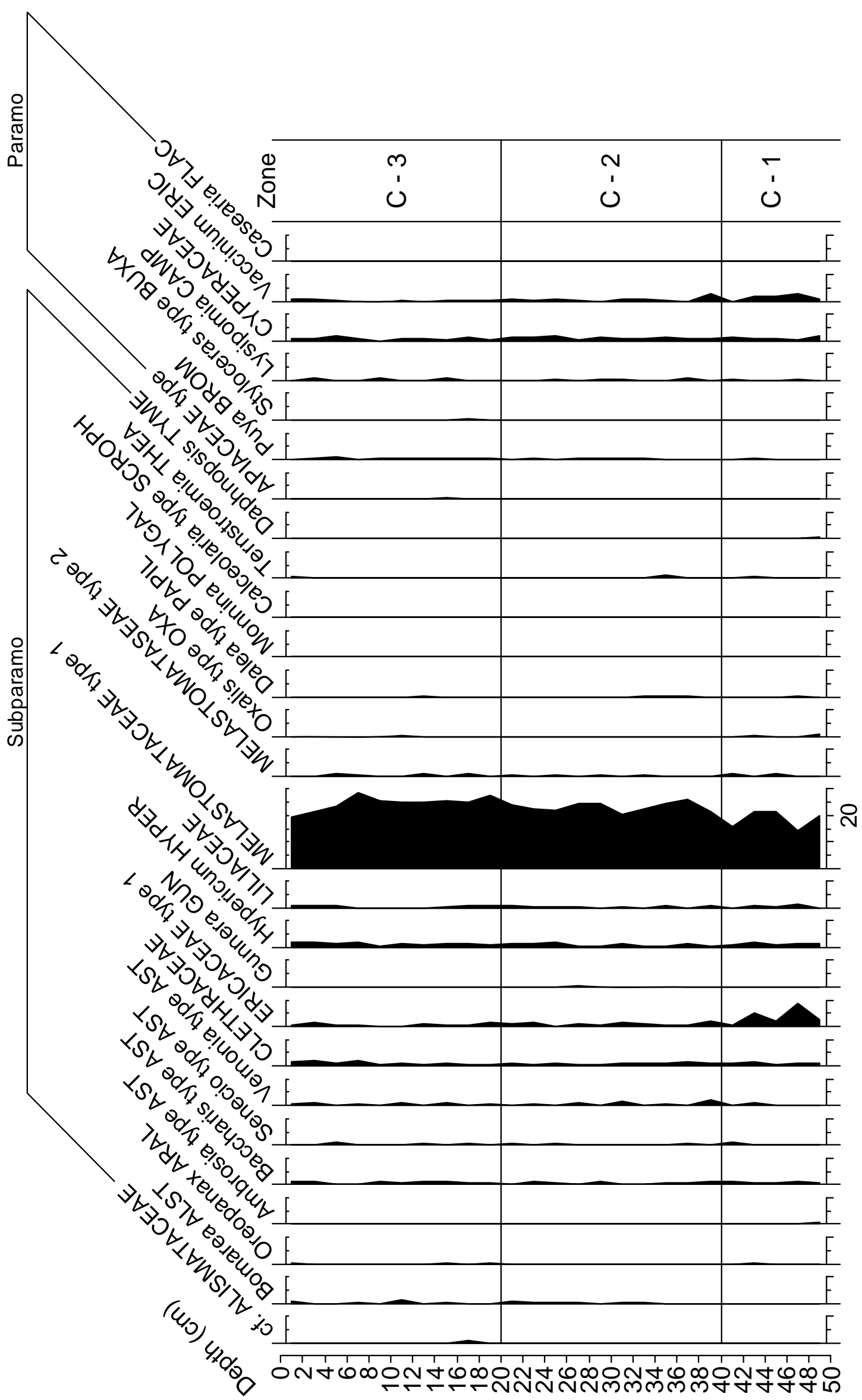

Complete record of ECSF-Cerro de Consuelo (2) 


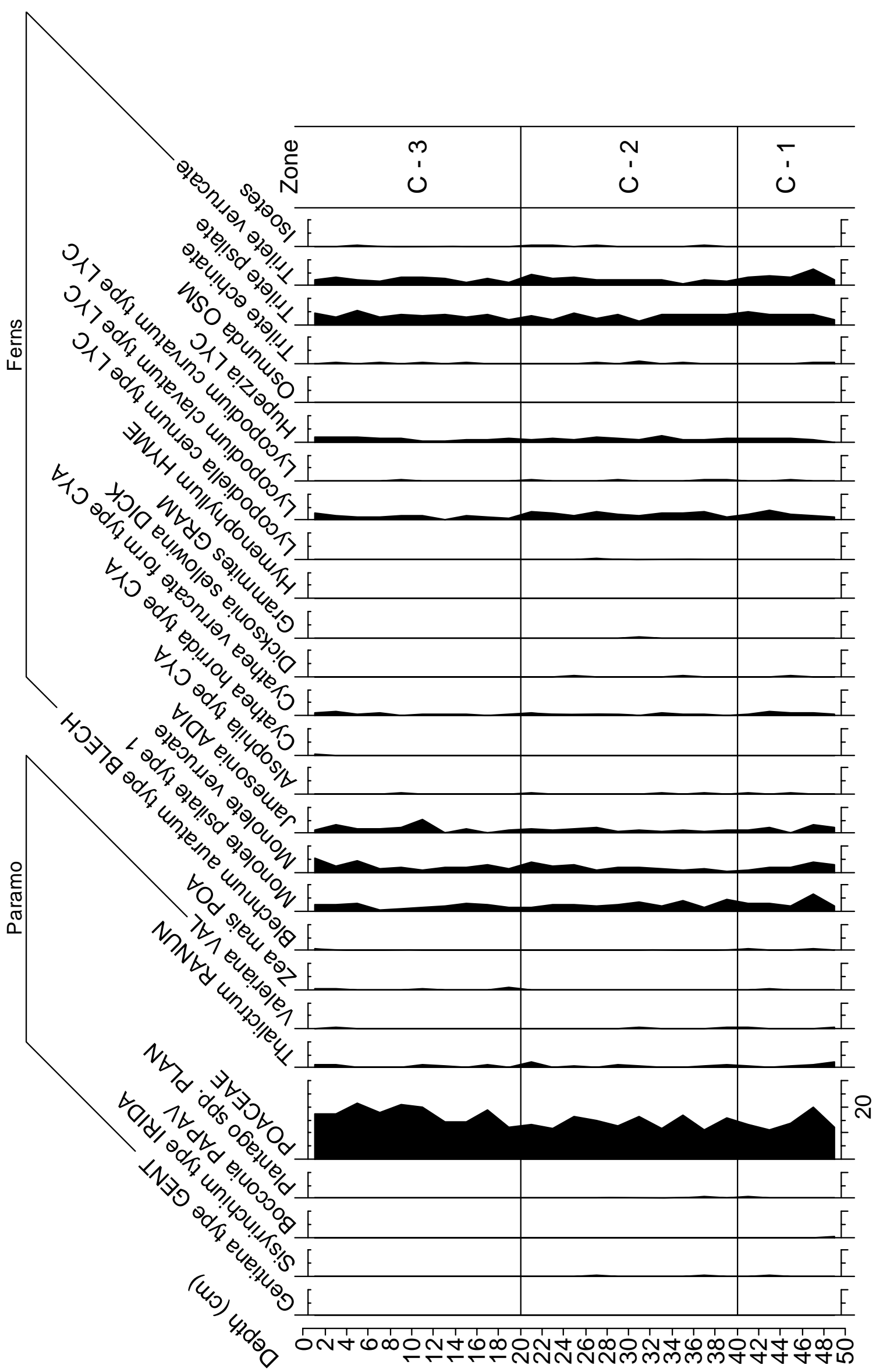

Complete record of ECSF-Cerro de Consuelo (3) 


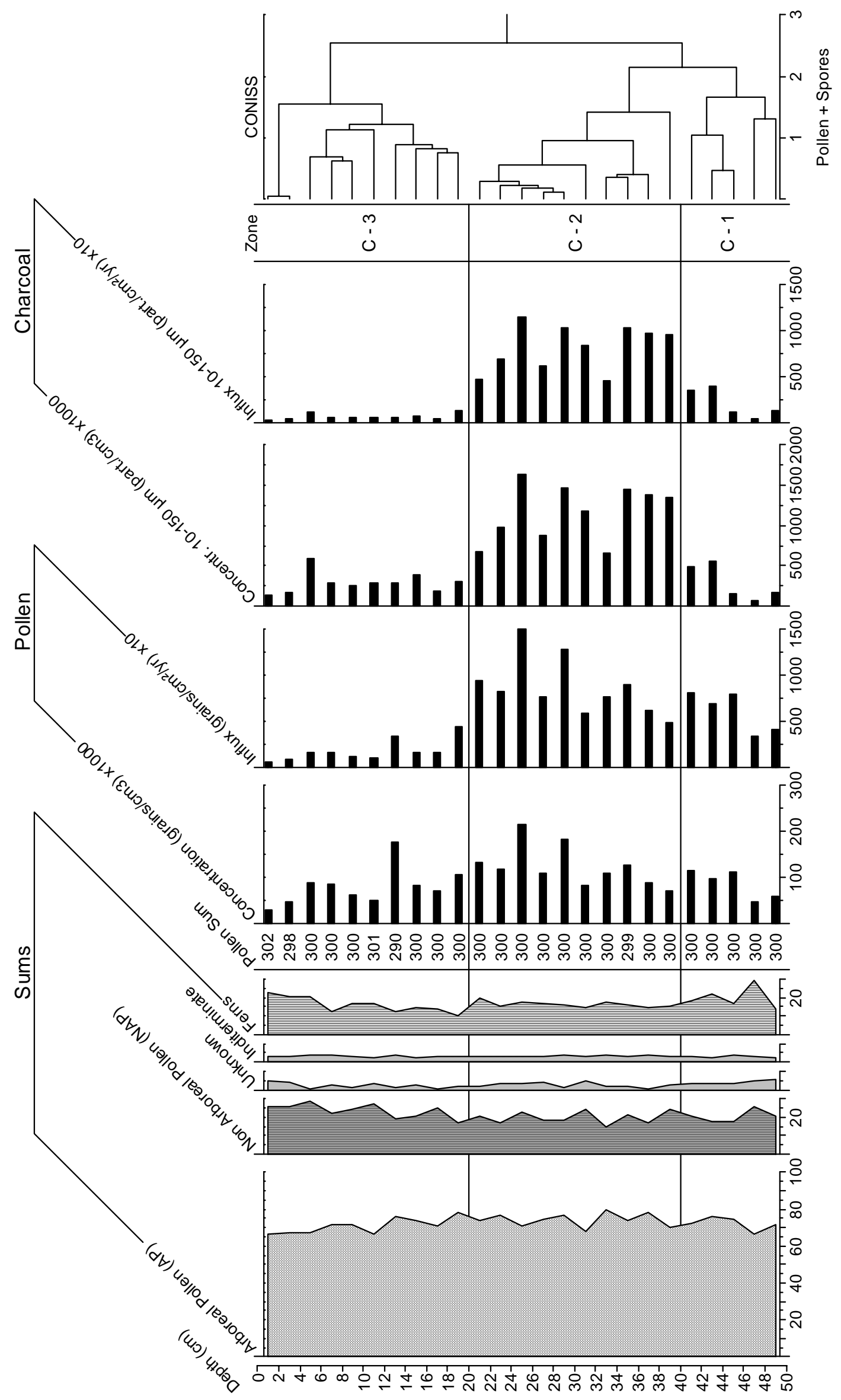

Complete record of ECSF-Cerro de Consuelo (4) 


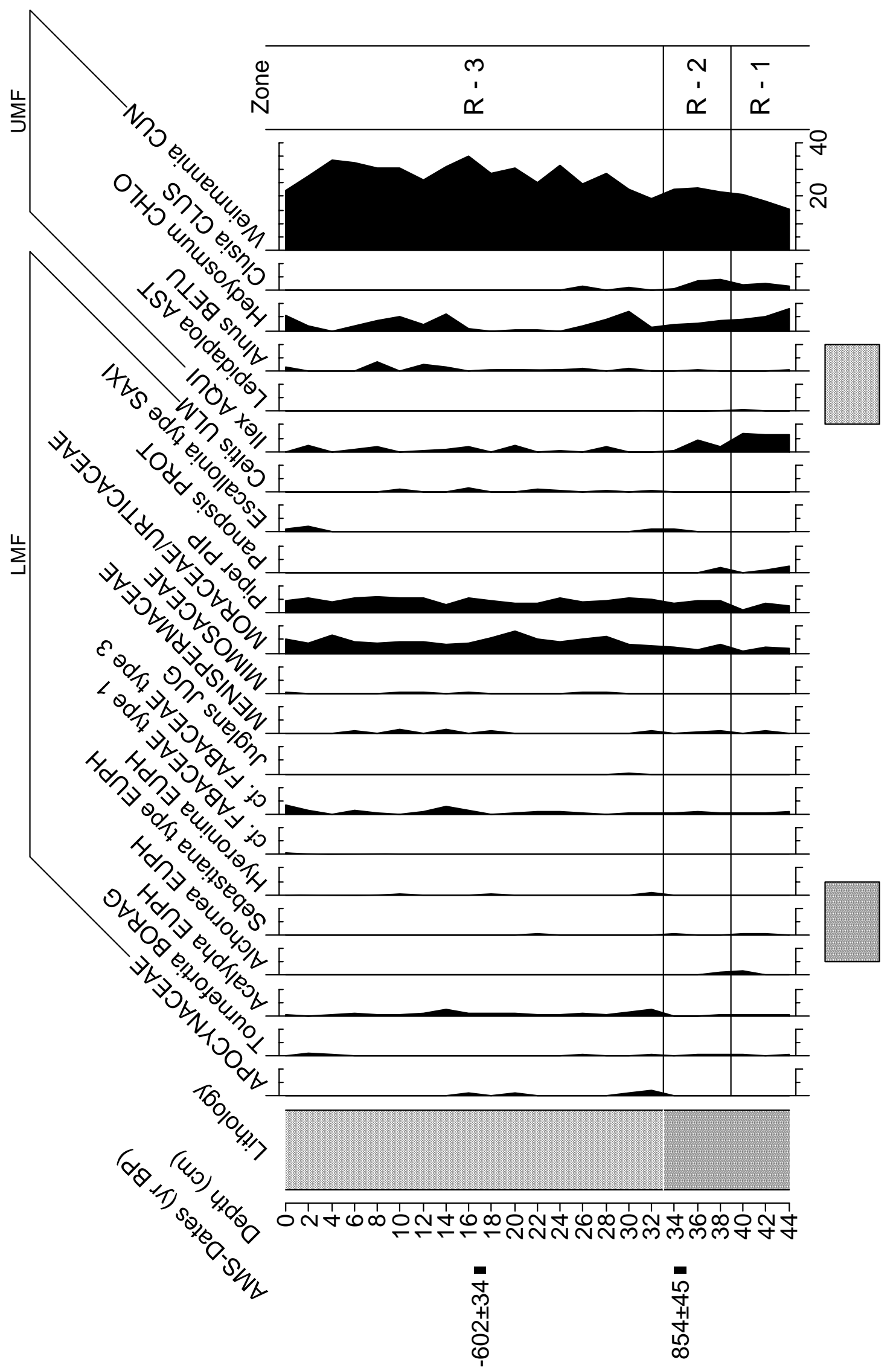

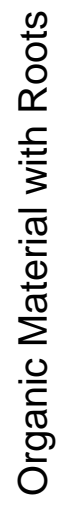

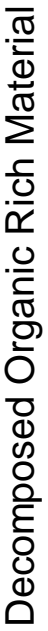




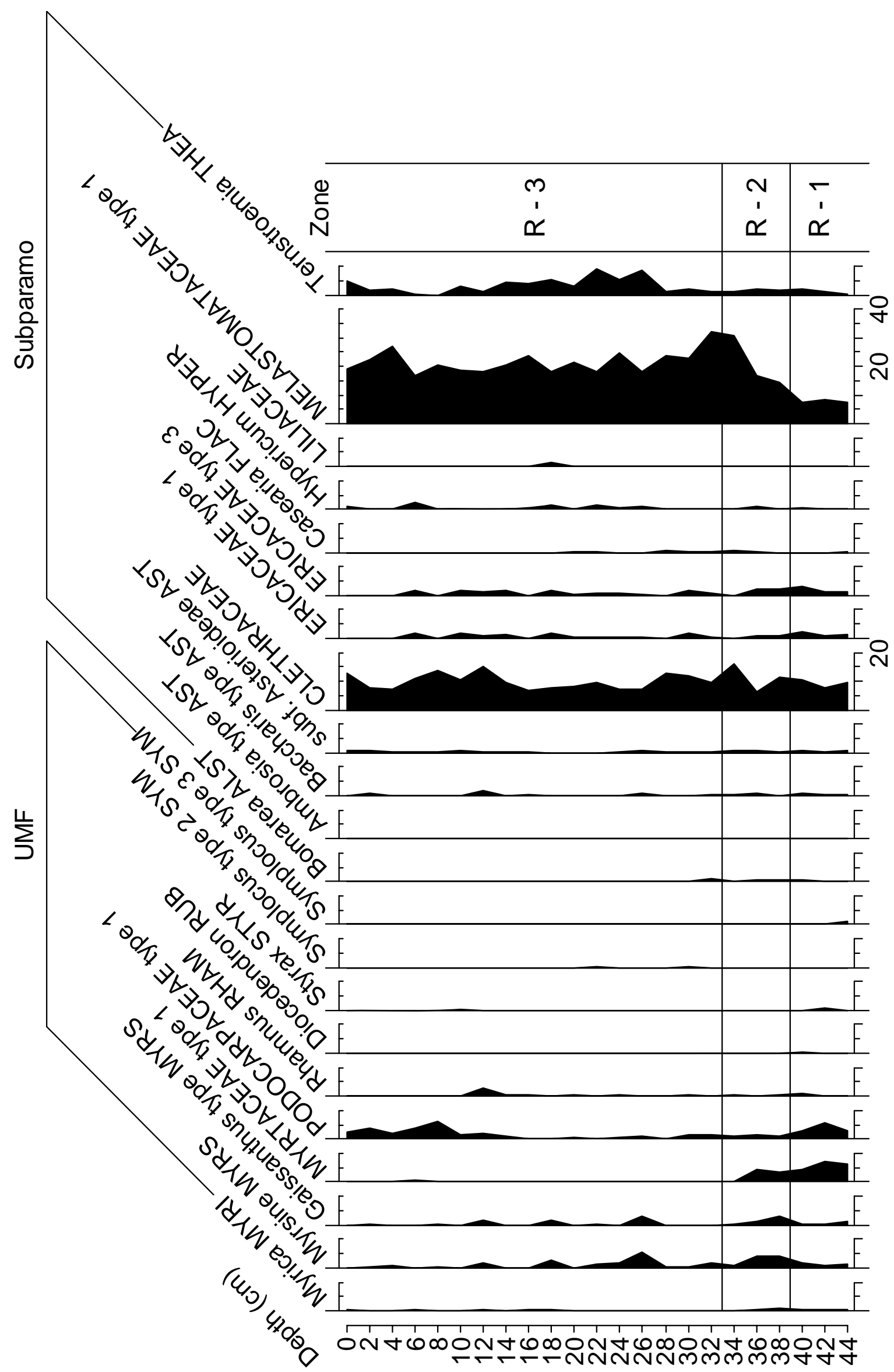

Complete record of ECSF-Refugio (2) 


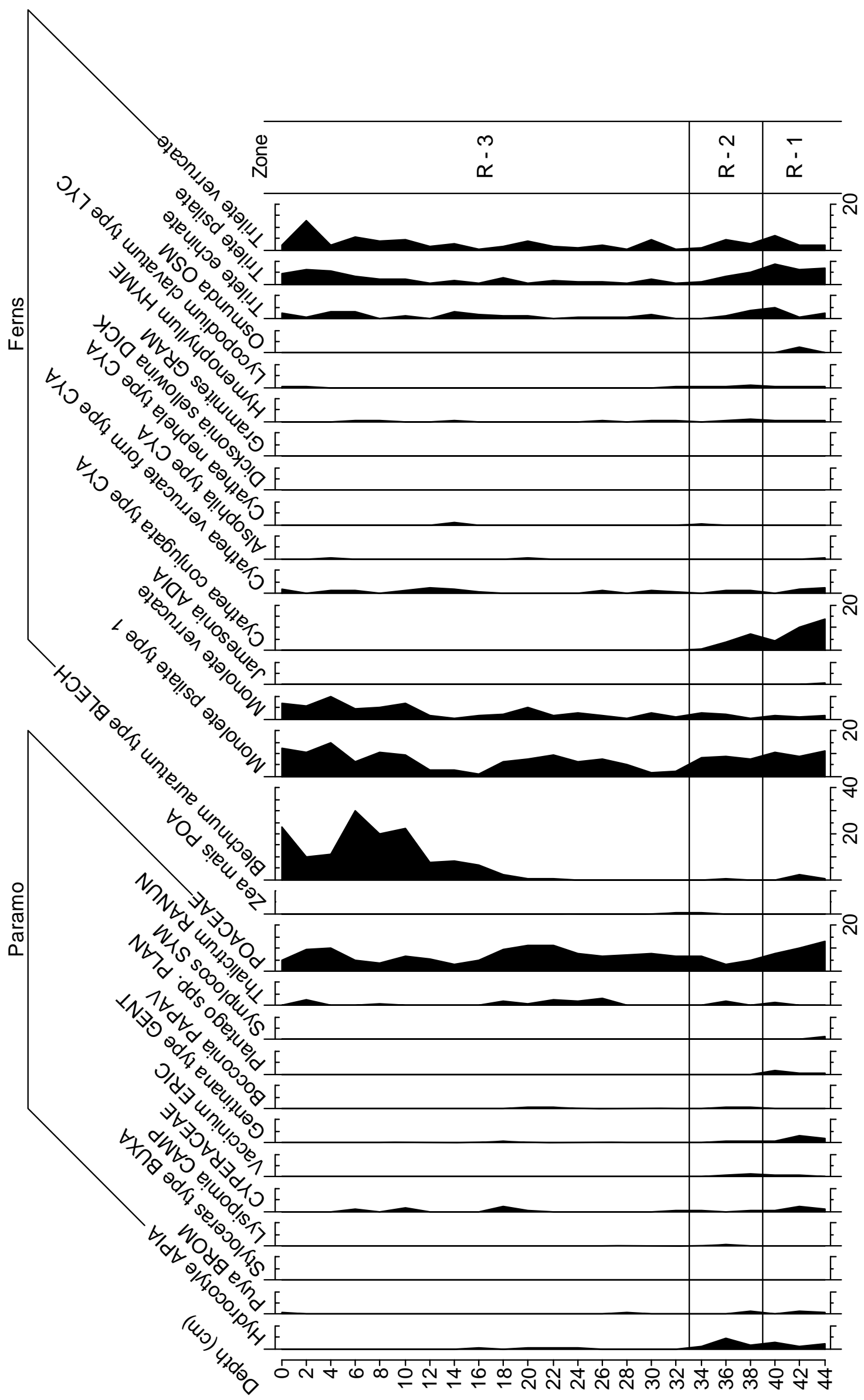




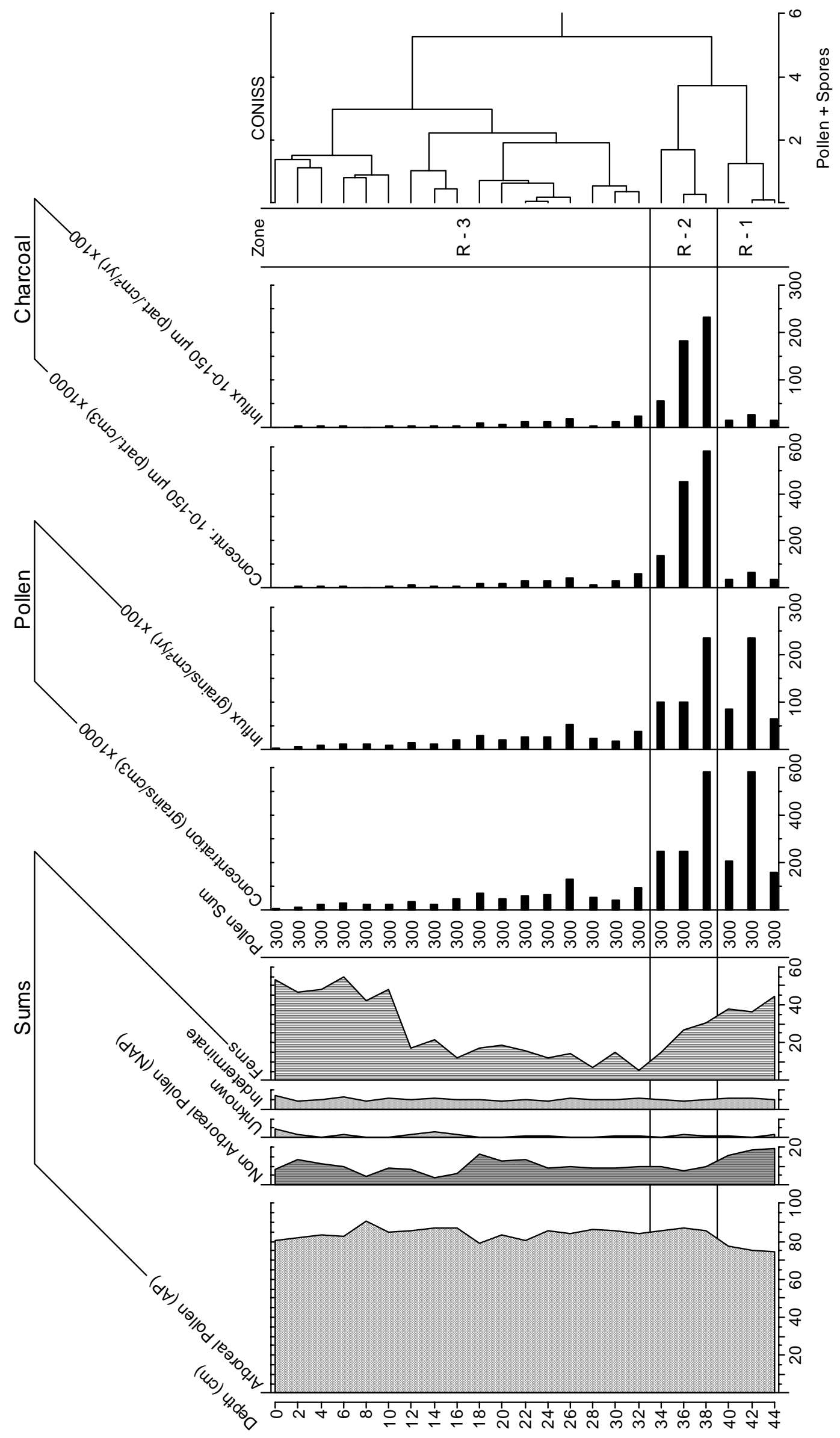

Complete record of ECSF-Refugio (4) 


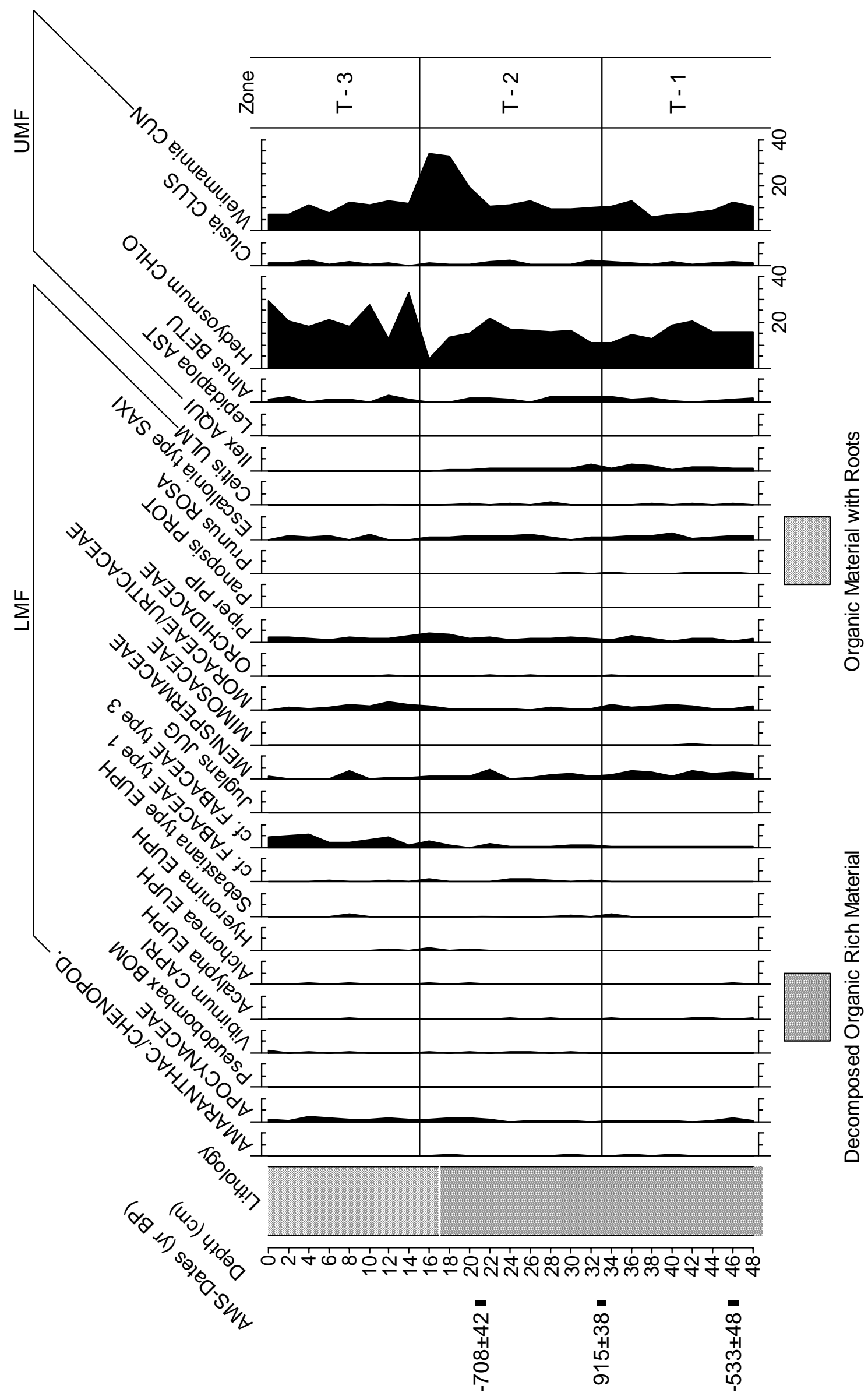




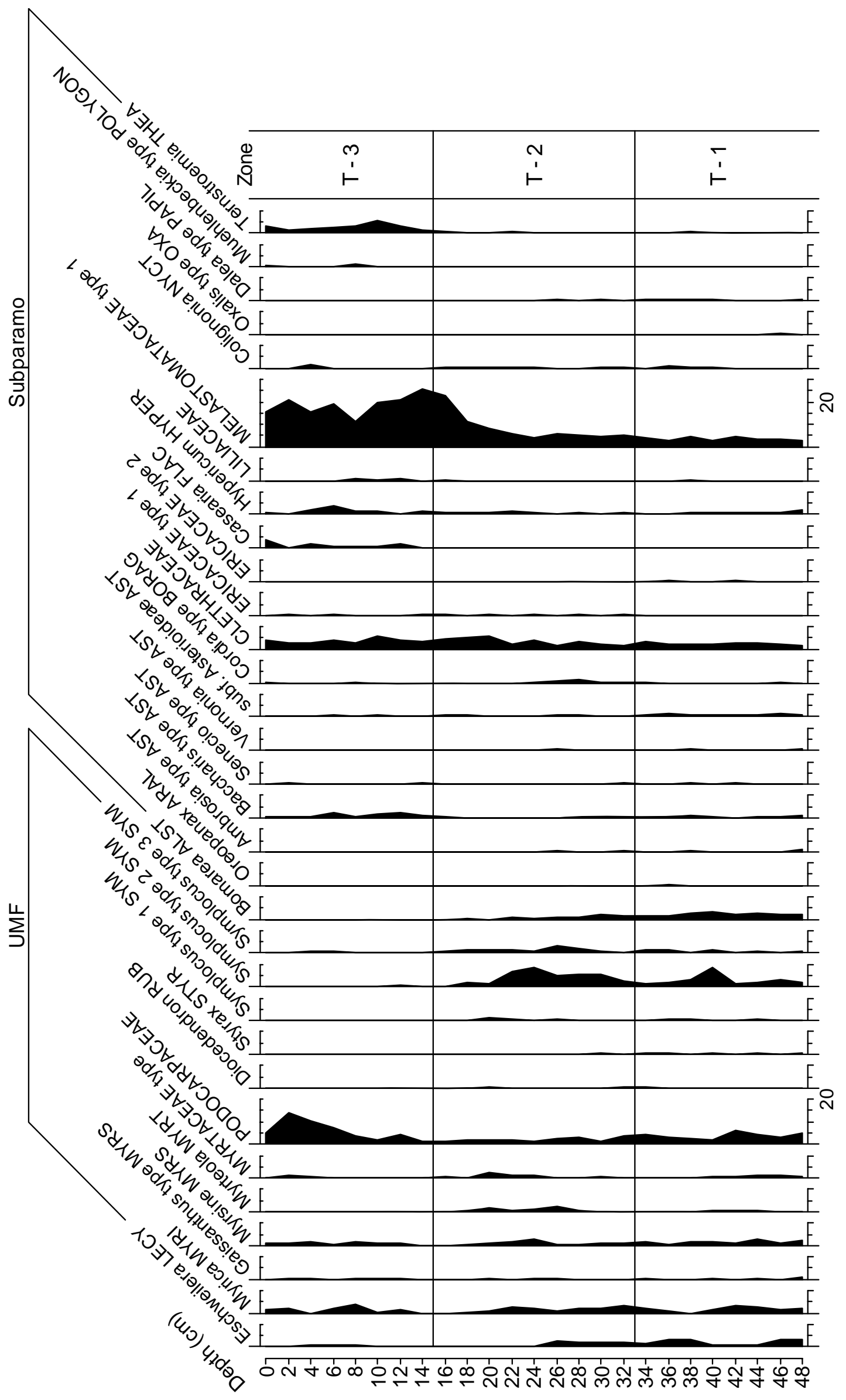

Complete record of ESCF-T2/250 (2) 


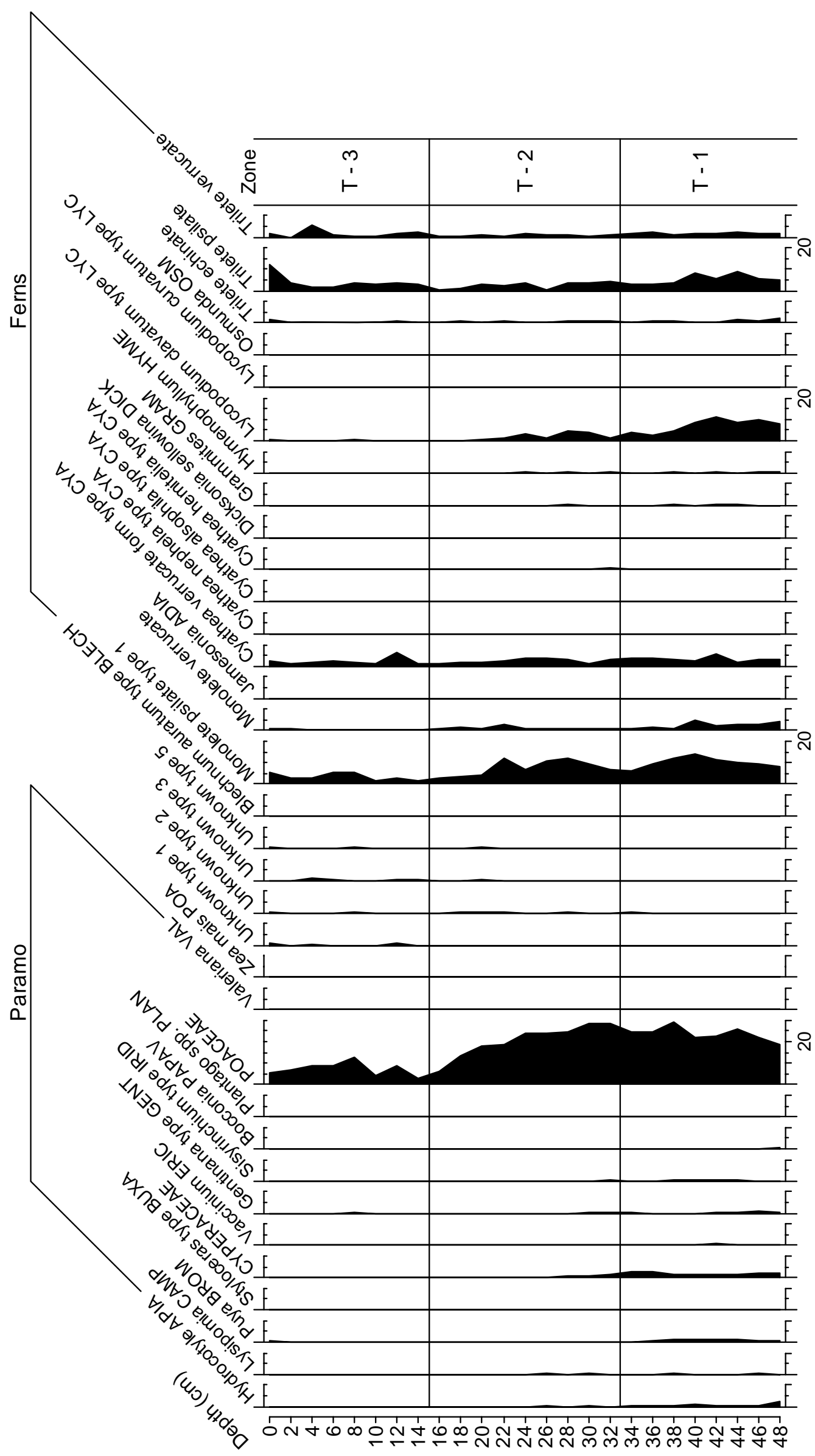

Complete record of ESCF-T2/250 (3) 


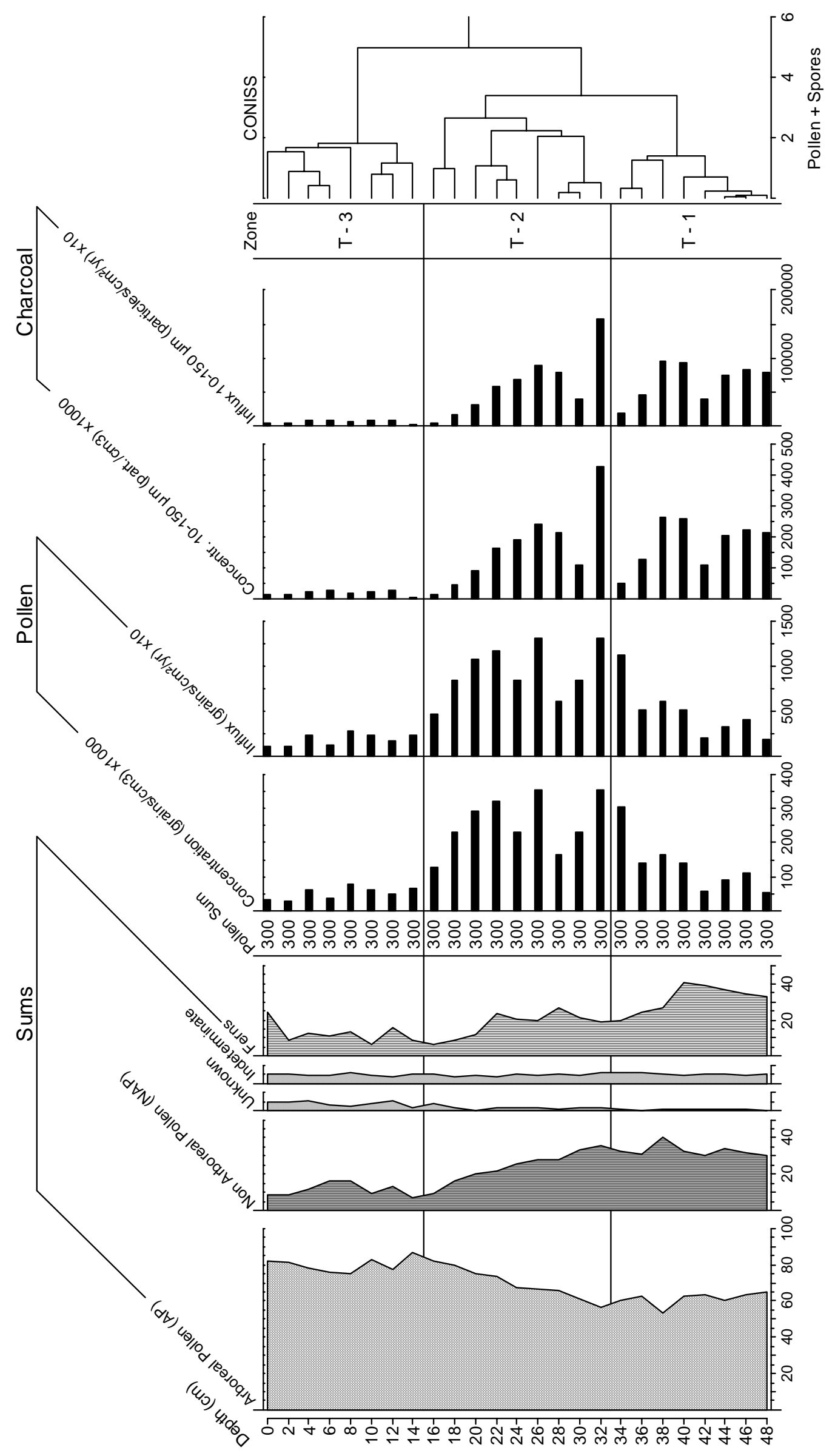

Complete record of ESCF-T2/250 (4) 


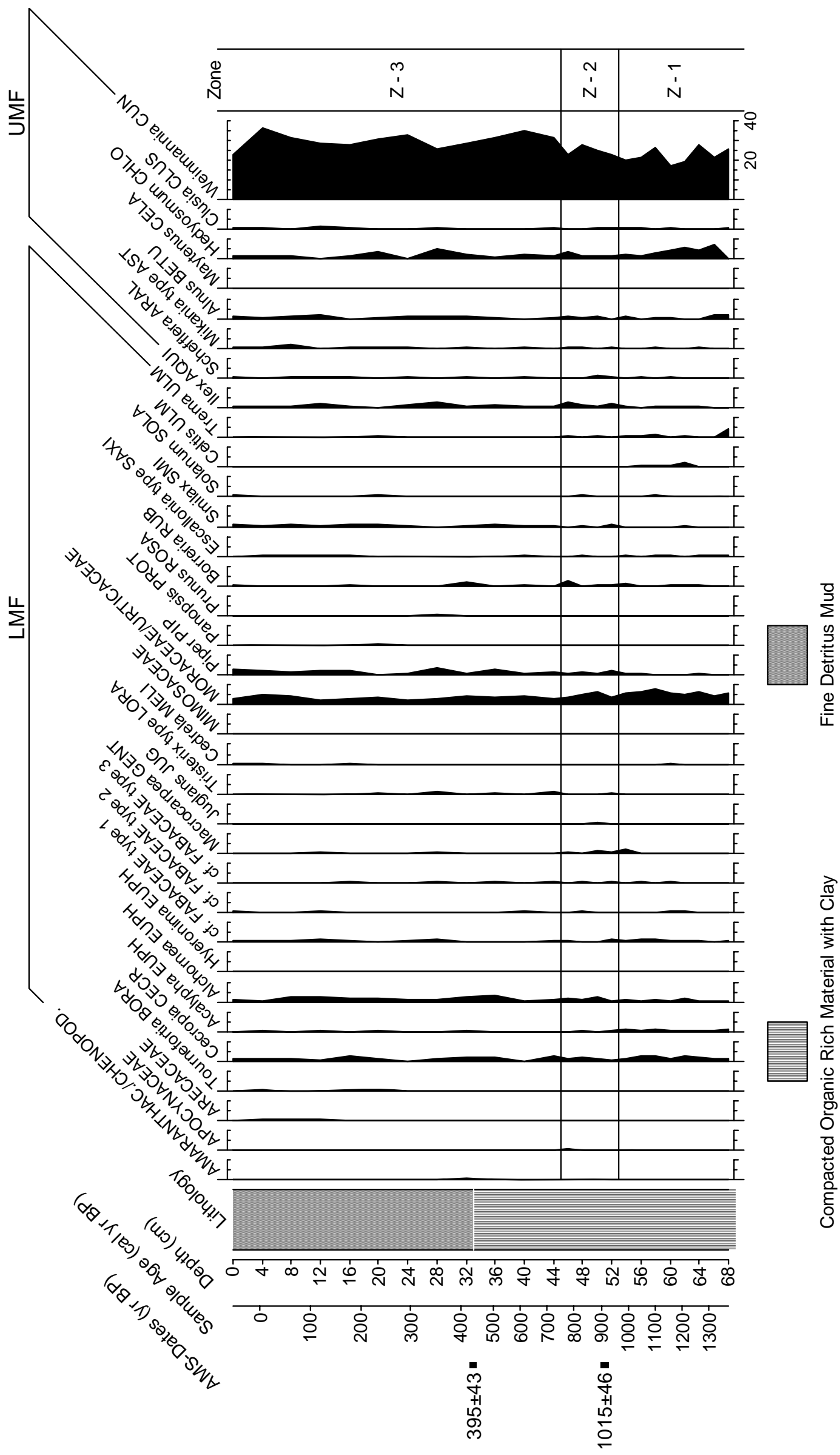




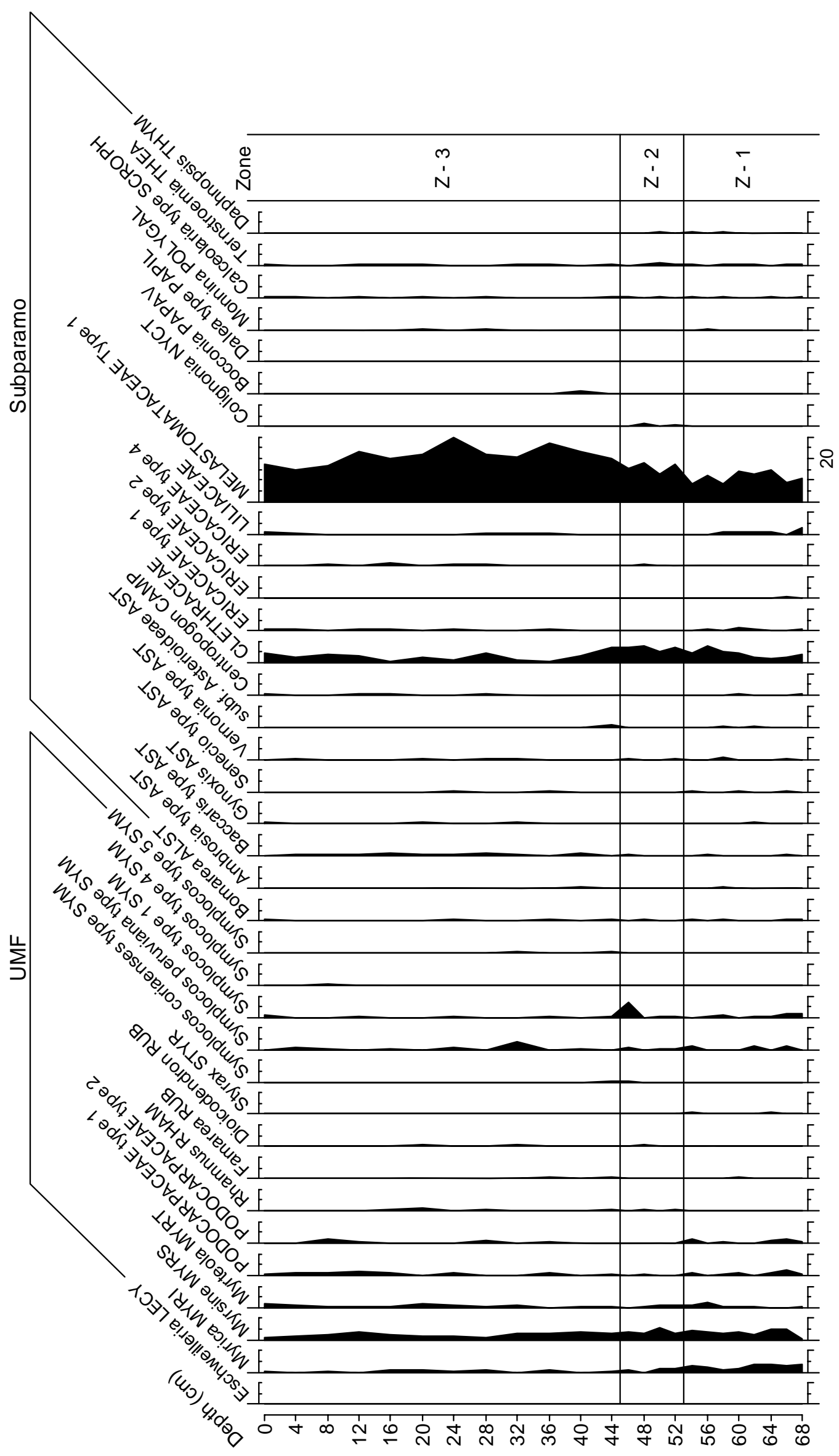

Complete record of Laguna Zurita (2) 


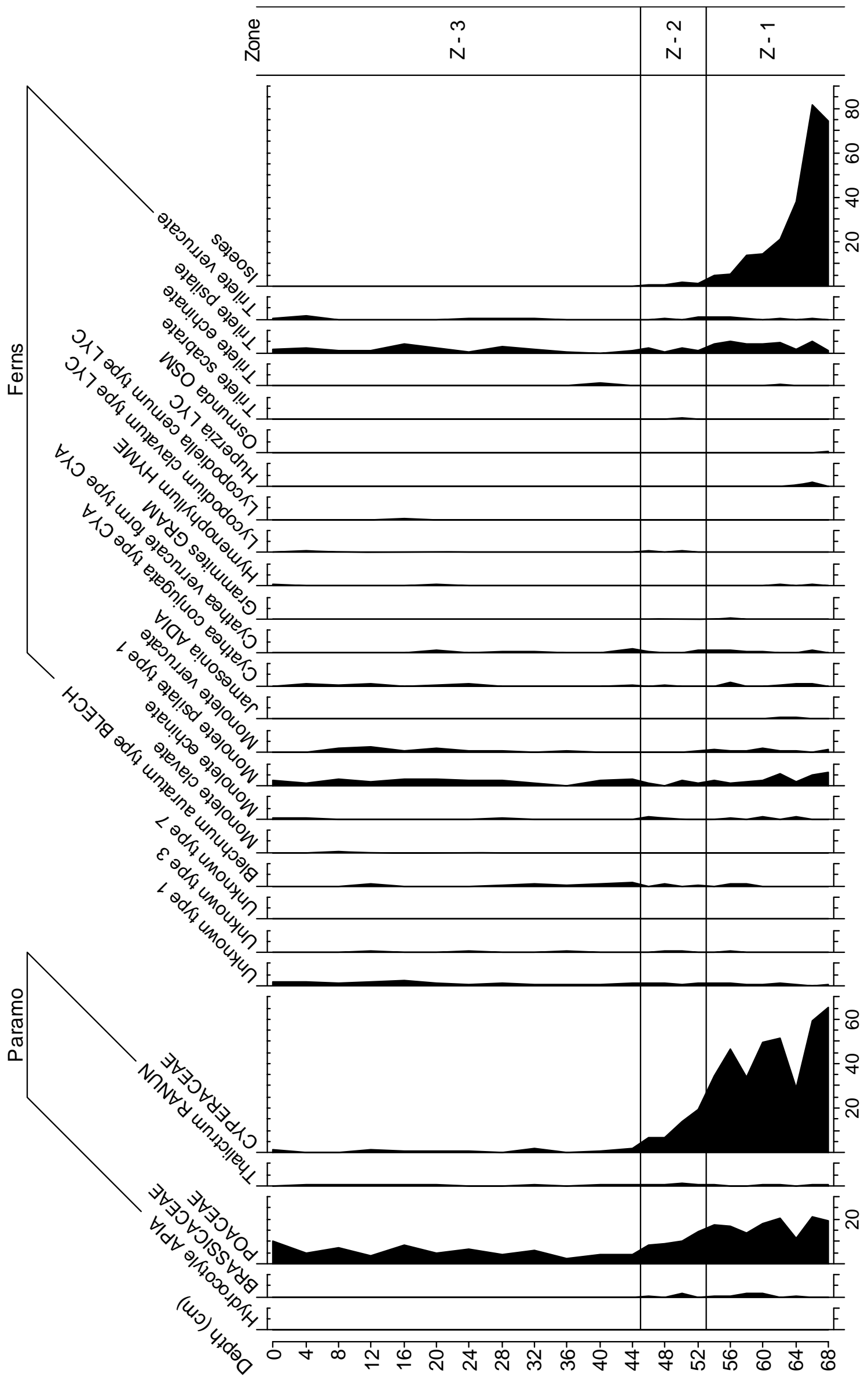

Complete record of Laguna Zurita (3) 


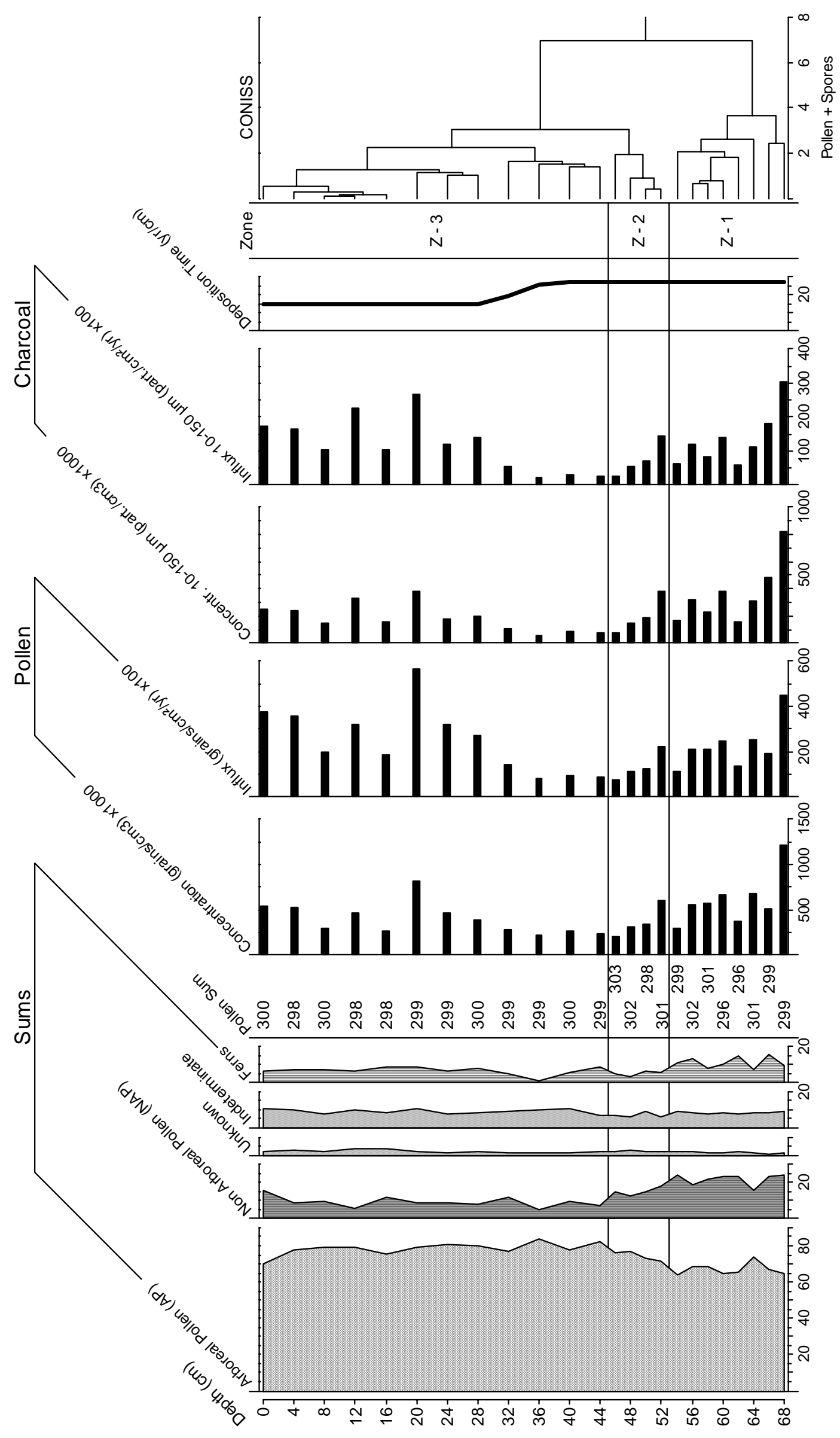

Complete record of Laguna Zurita (4) 


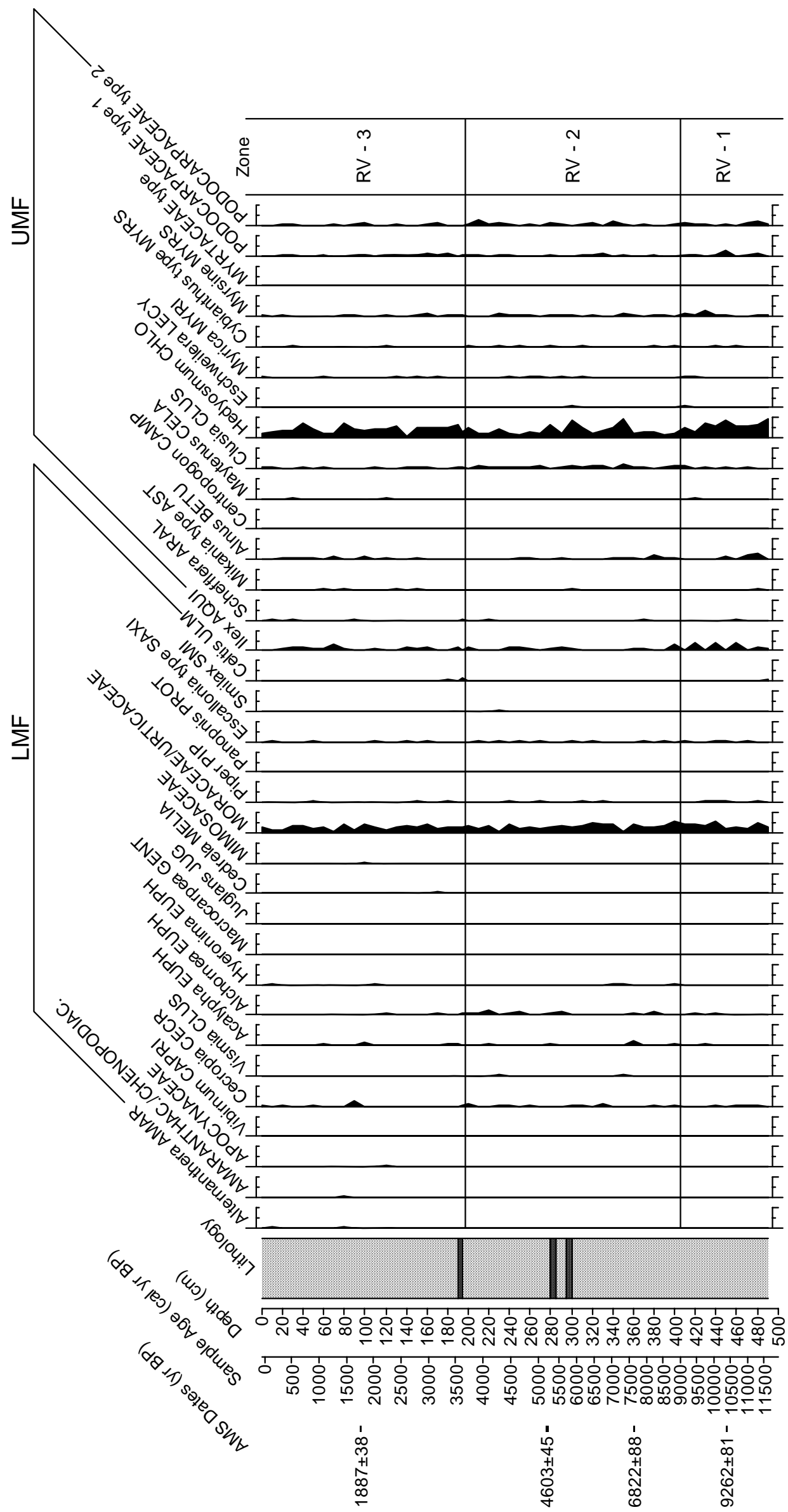




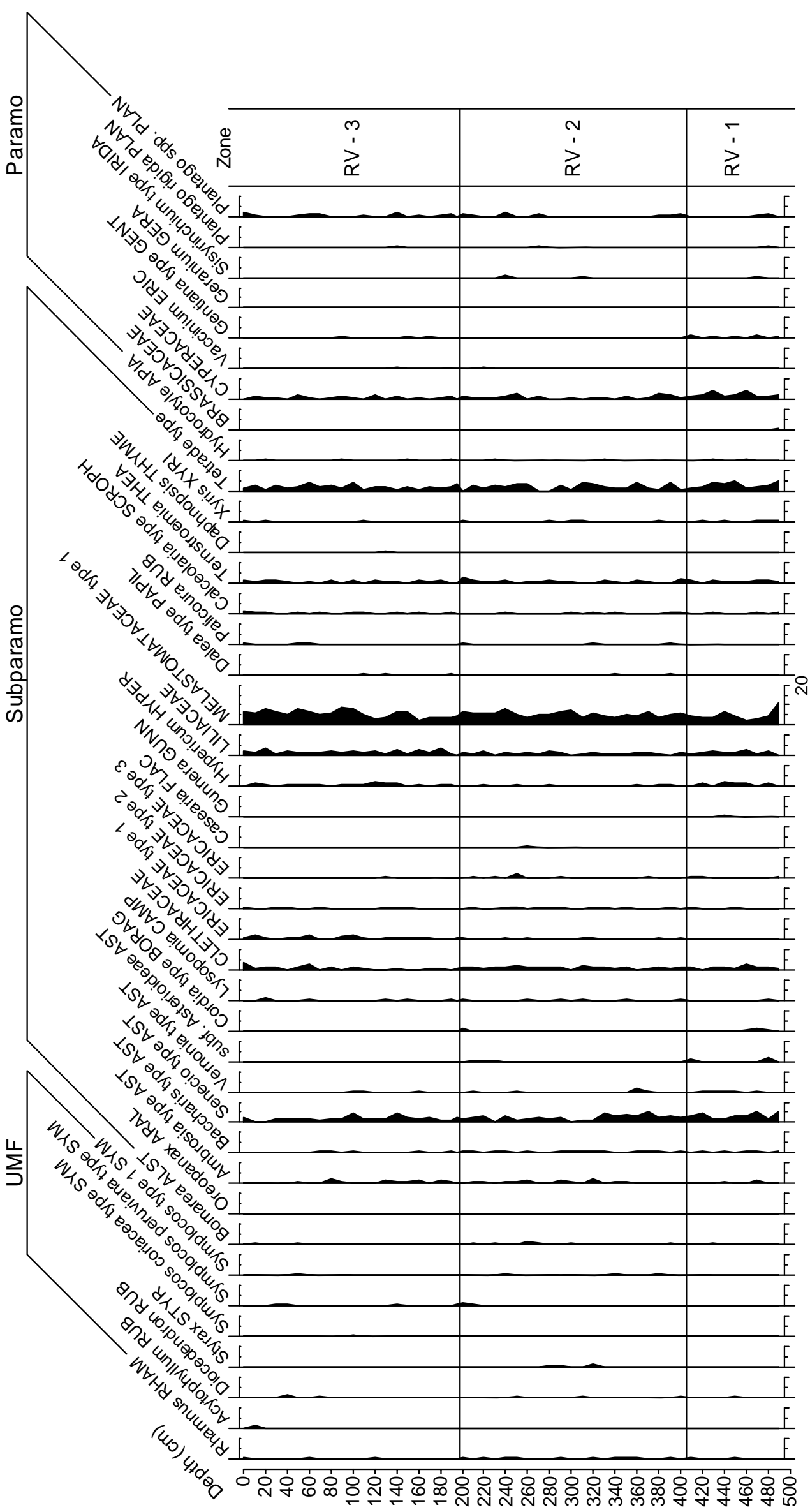

Complete record of Laguna Rabadilla de Vaca (2) 


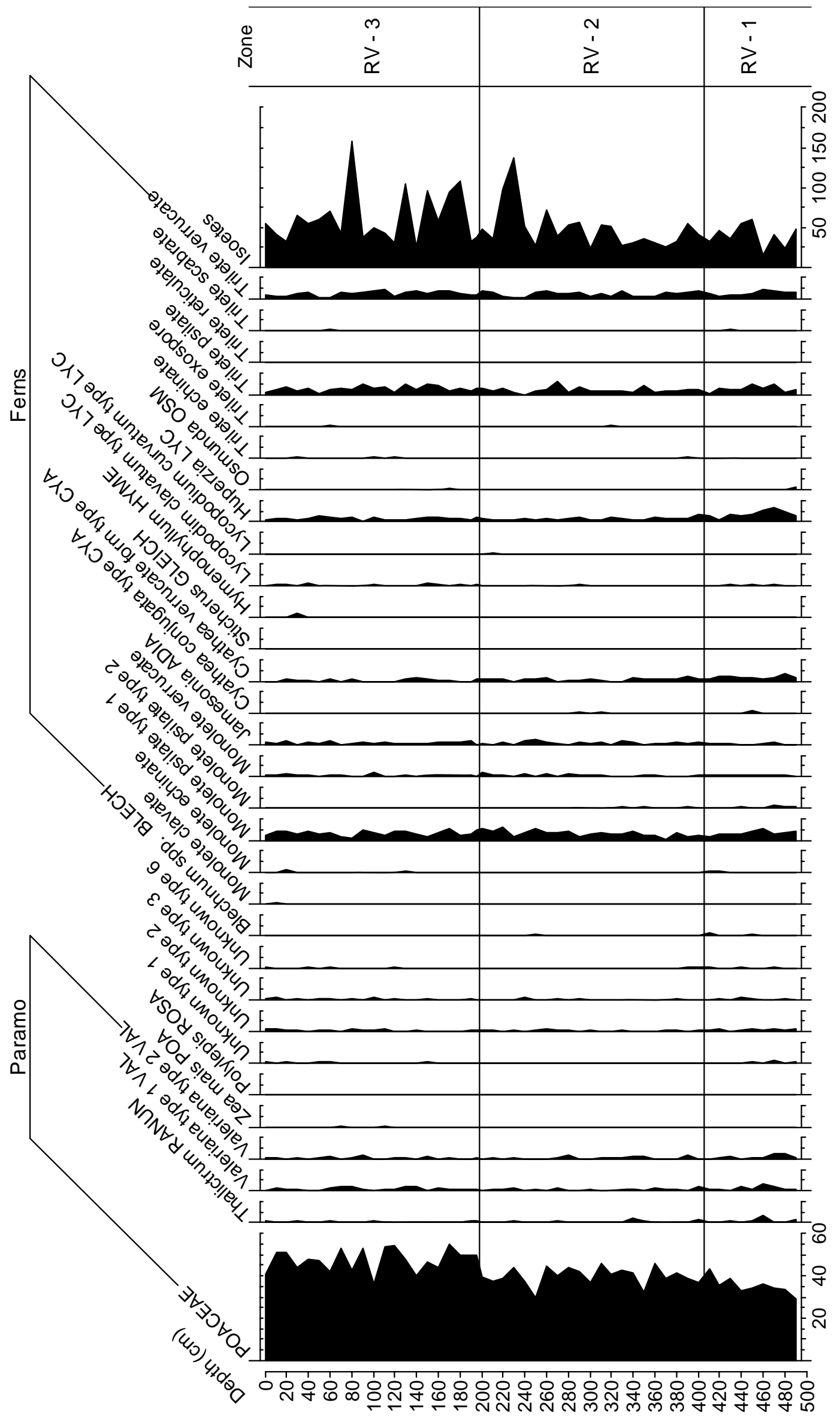

Complete record of Laguna Rabadilla de Vaca (3) 


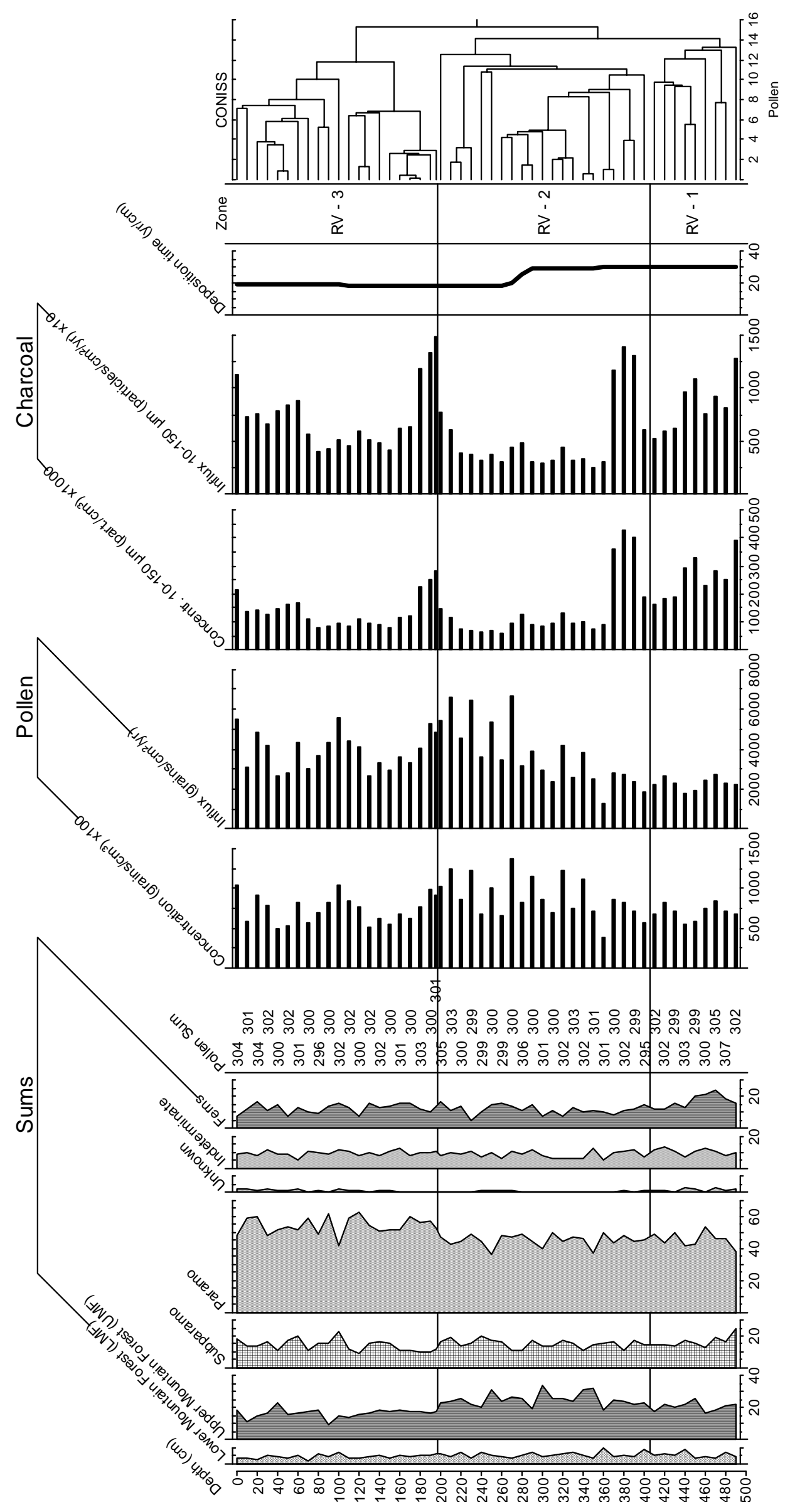

Complete record of Laguna Rabadilla de Vaca (4) 


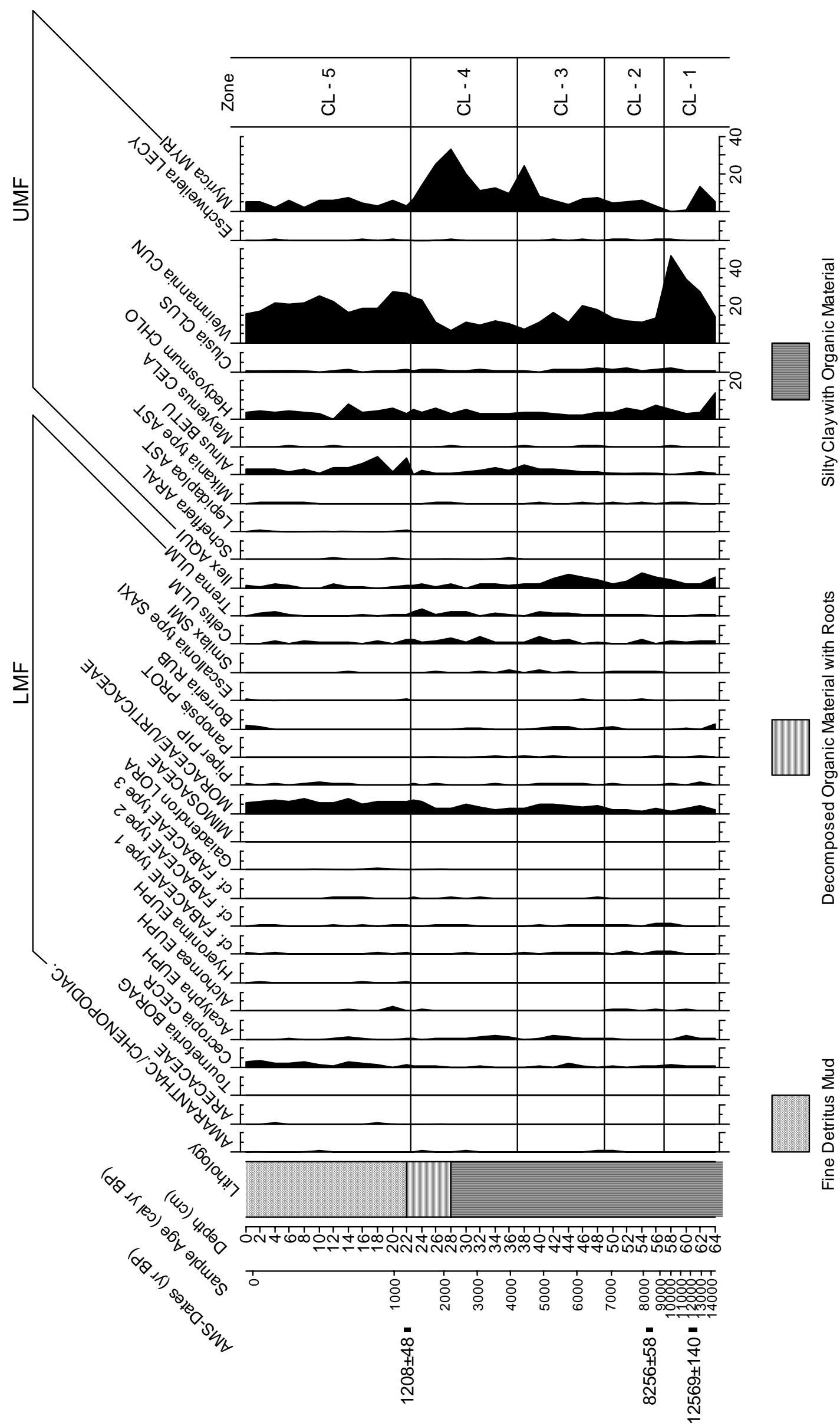

Complete record of Laguna Cocha Caranga (1) 


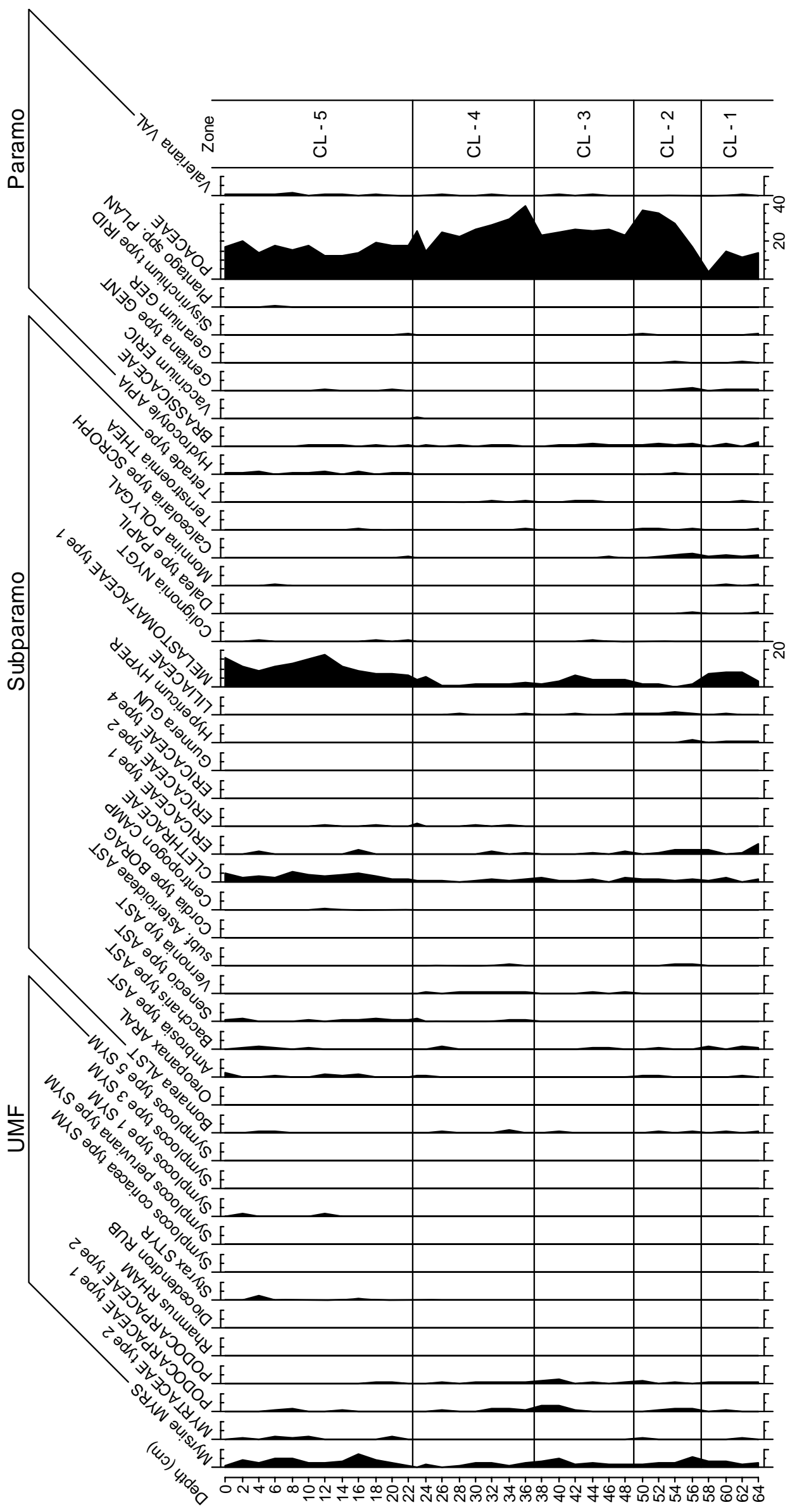

Complete record of Laguna Cocha Caranga (2) 


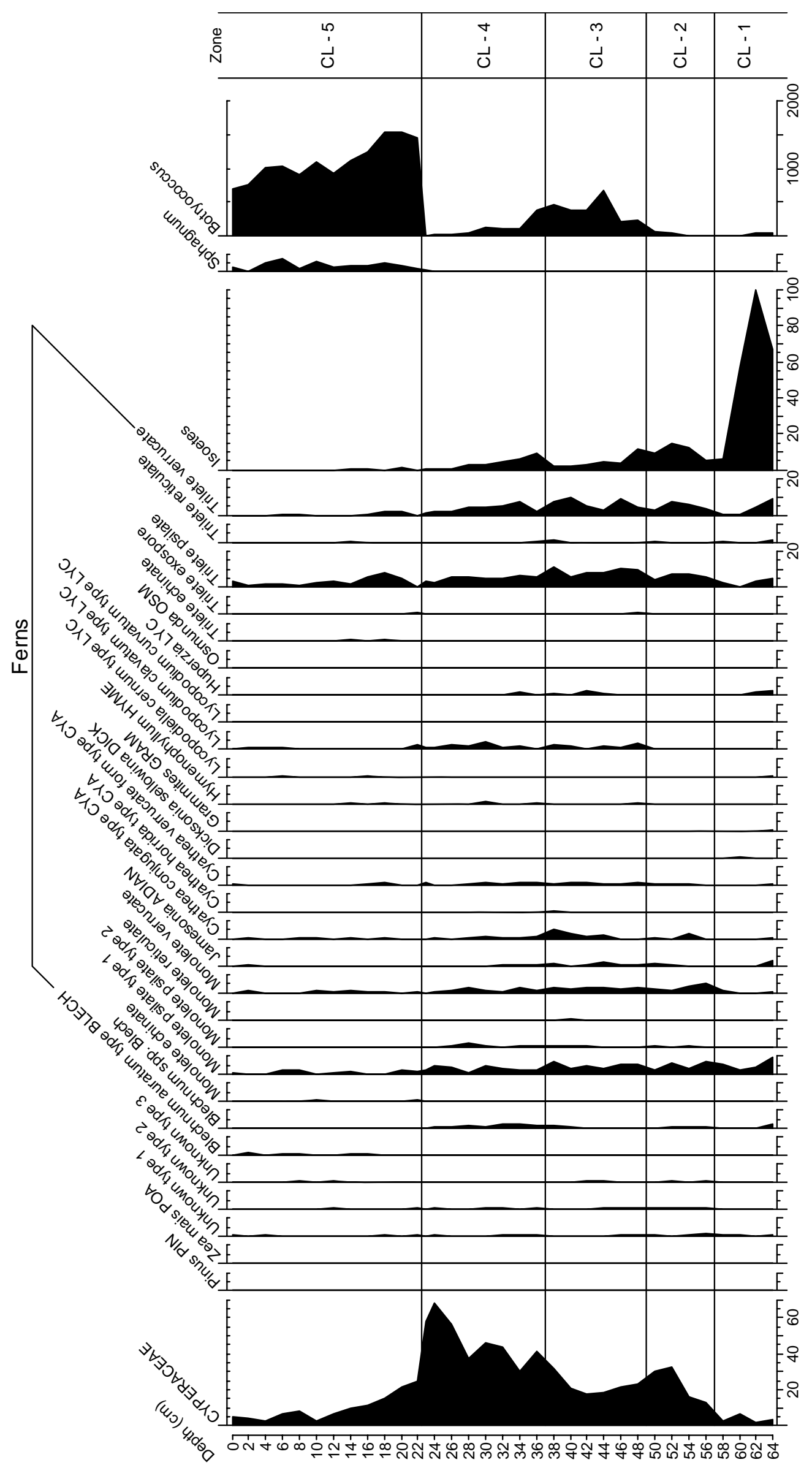

Complete record of Laguna Cocha Caranga (3) 


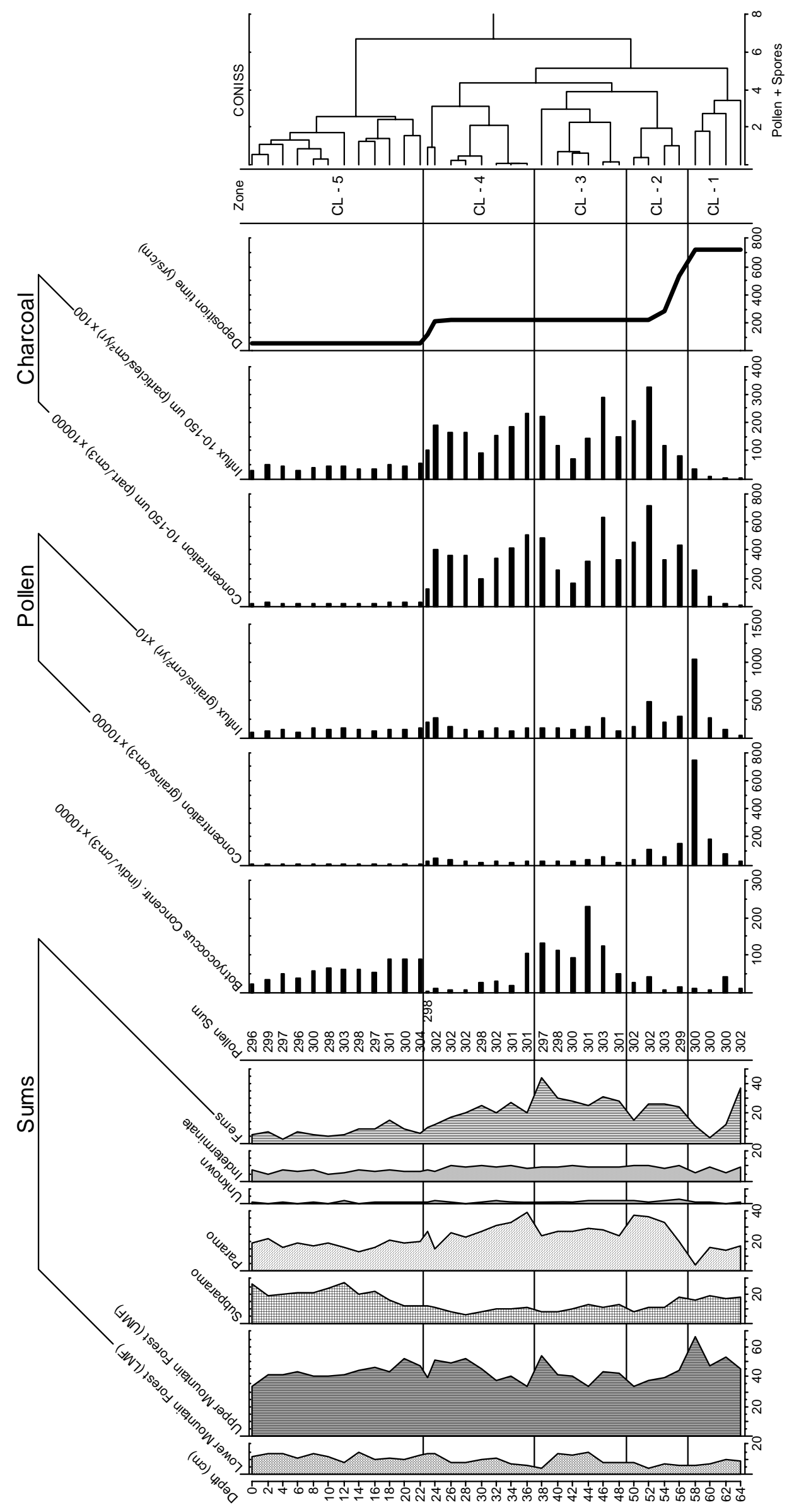

Complete record of Laguna Cocha Caranga (4) 


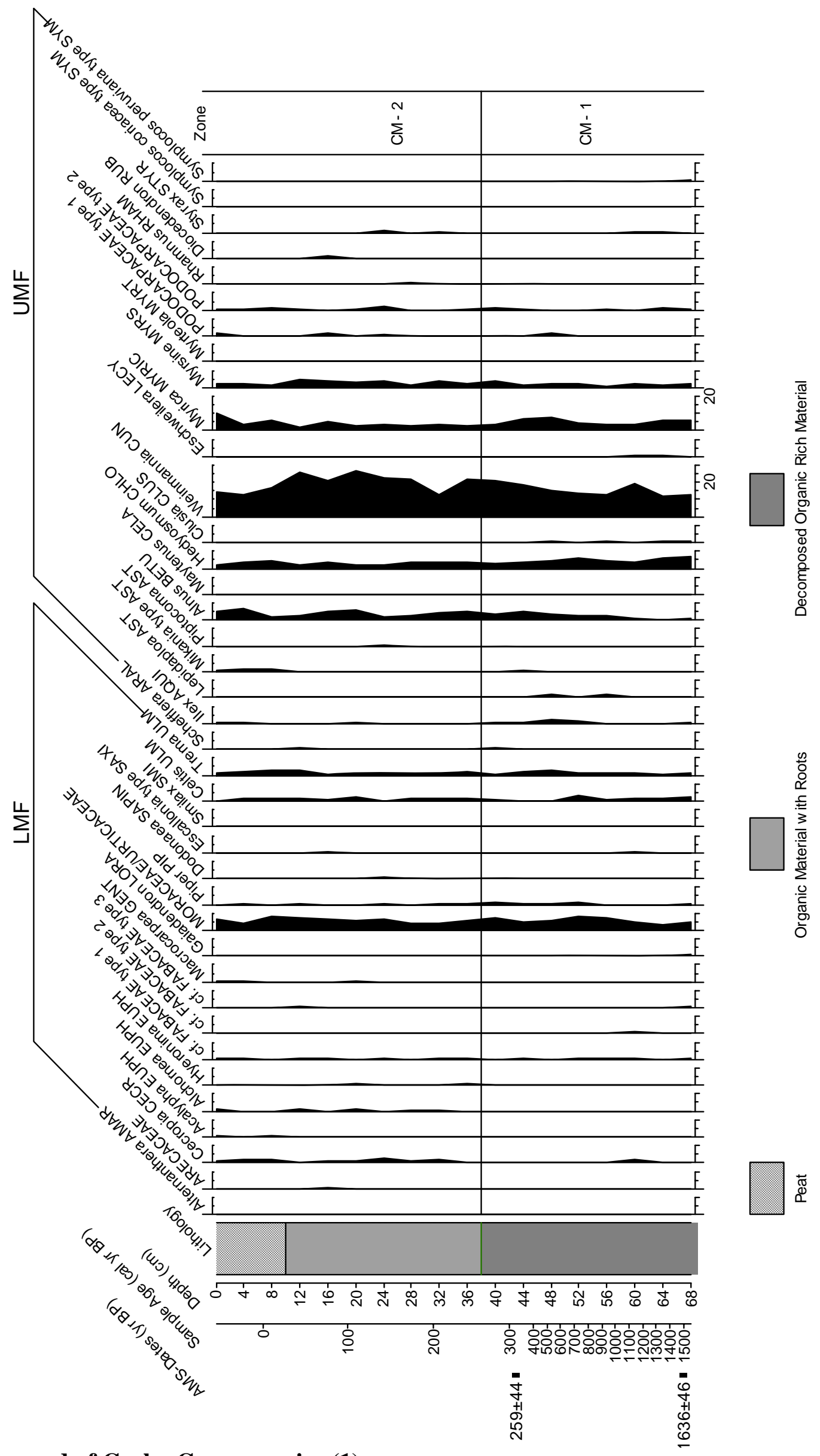

Complete record of Cocha Caranga mire (1) 


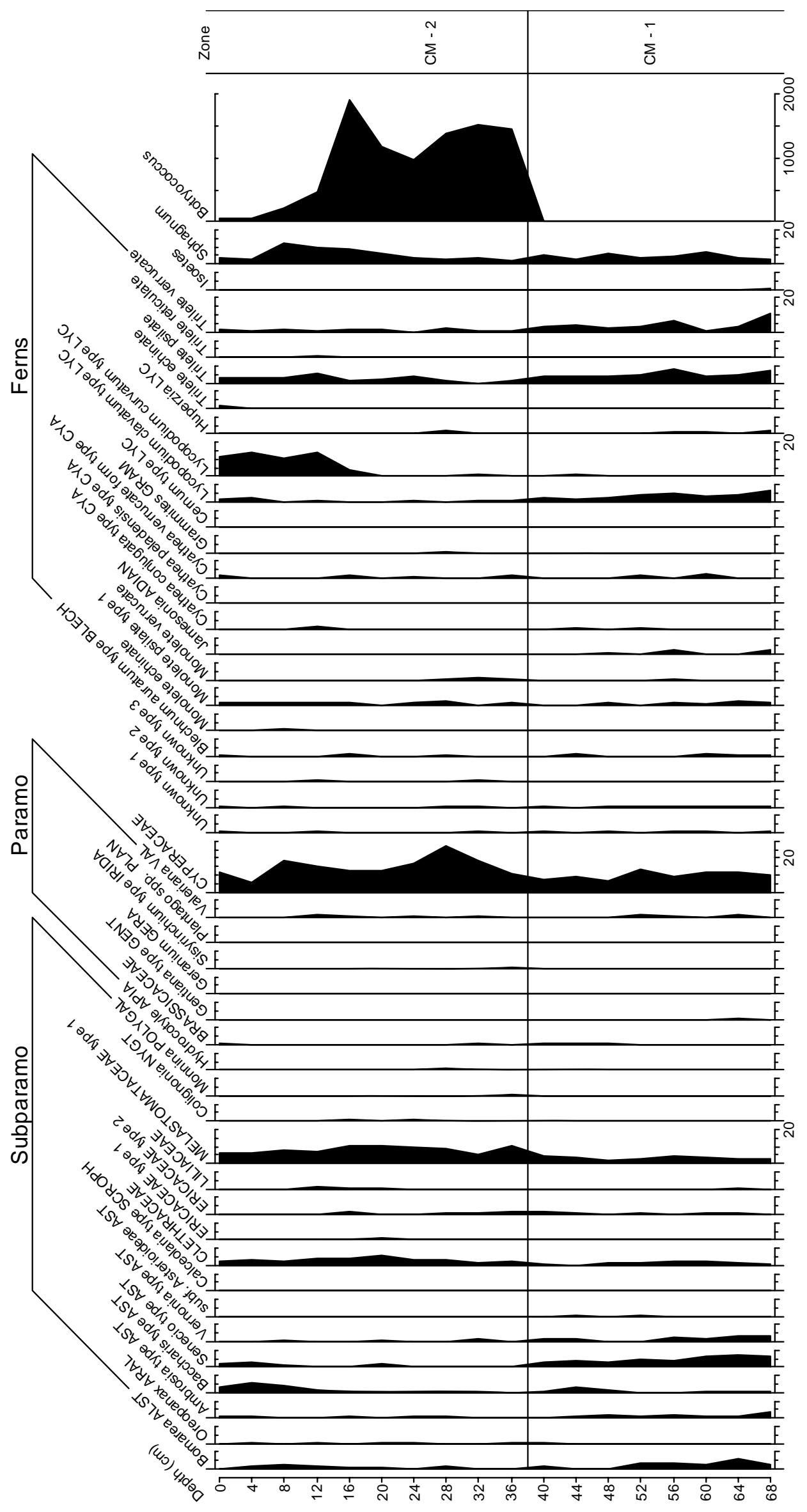

Complete record of Cocha Caranga mire (2) 


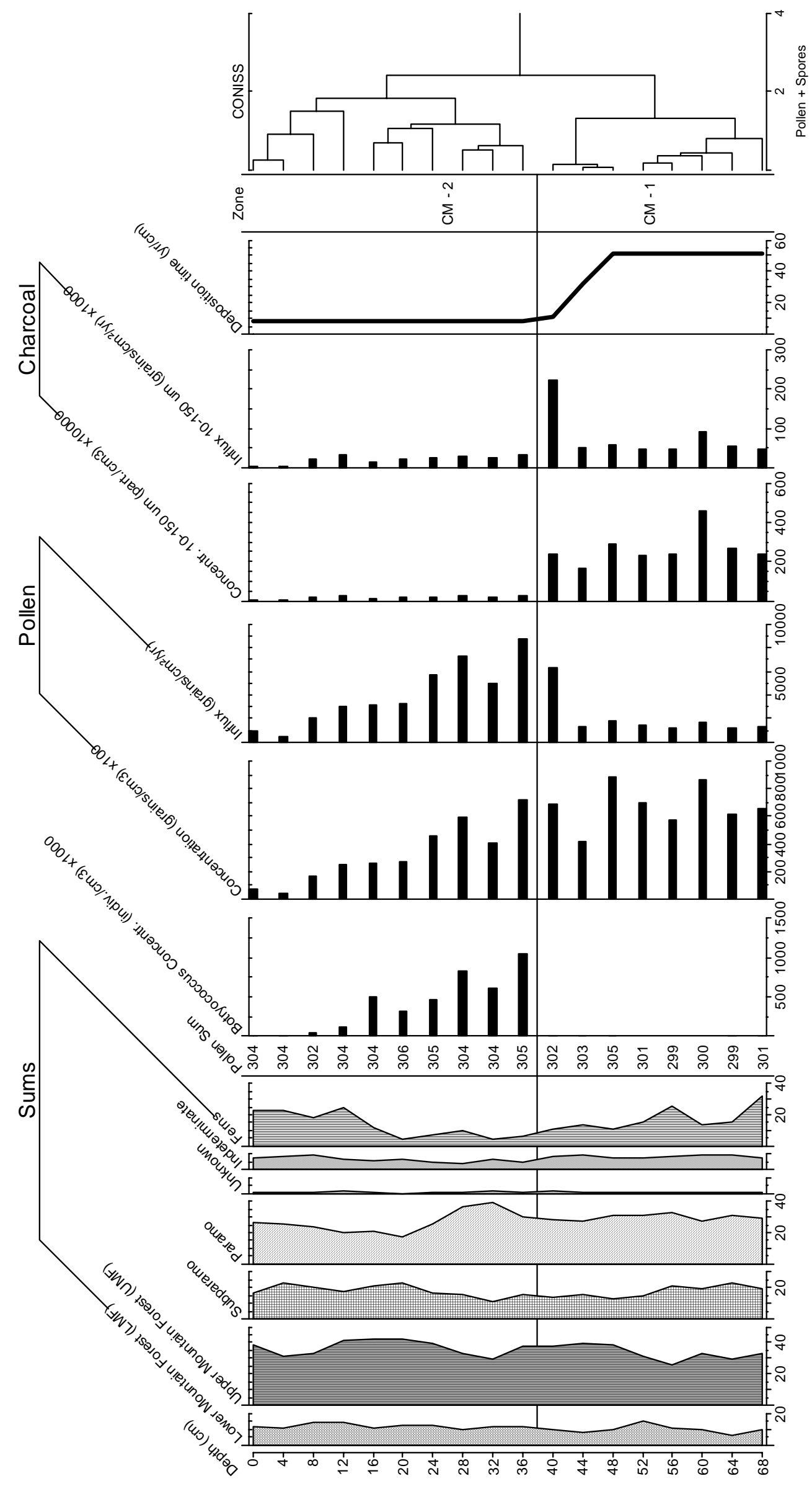

Complete record of Cocha Caranga mire (3) 


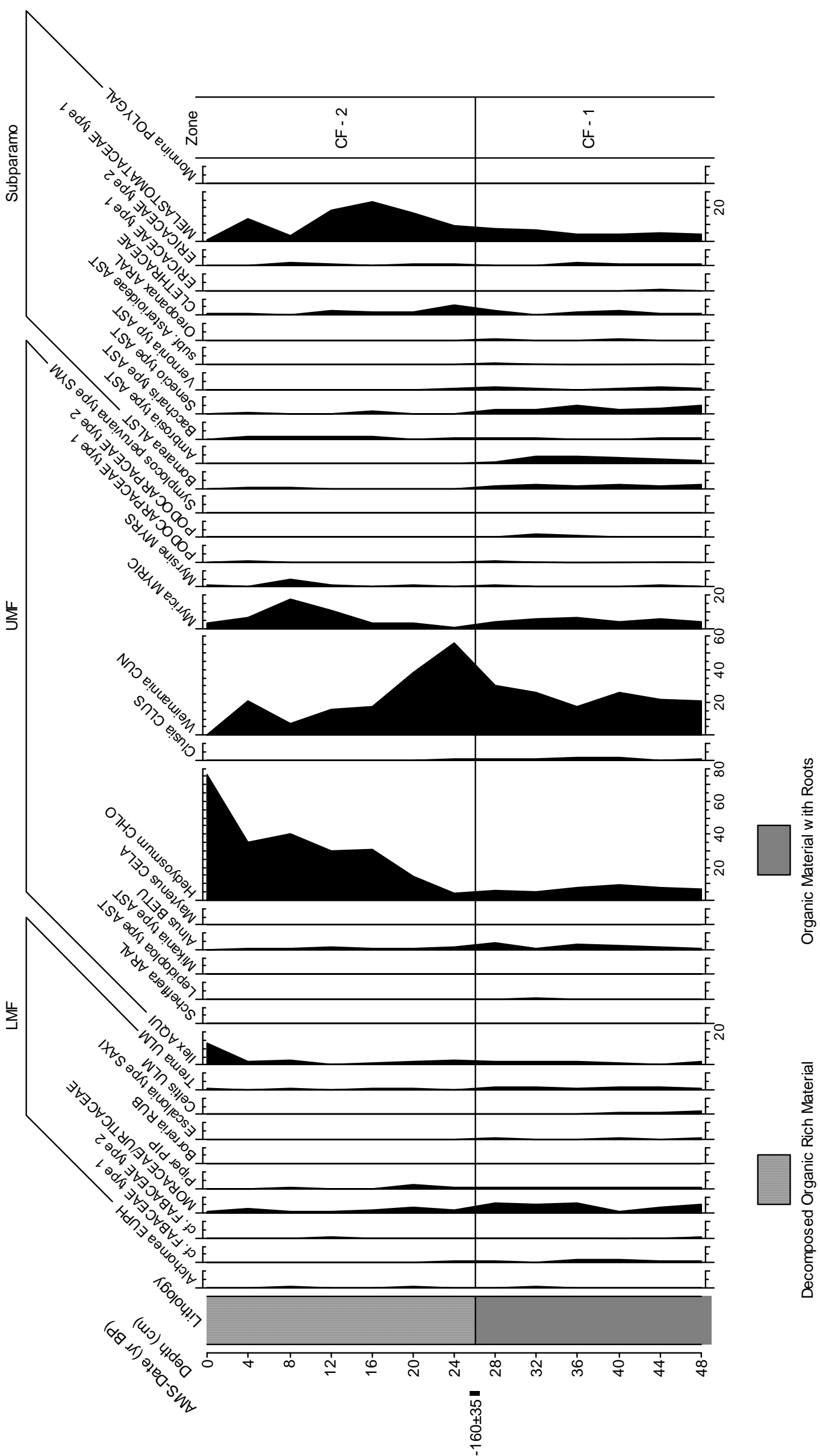

Complete record of Cocha Caranga forest (1) 


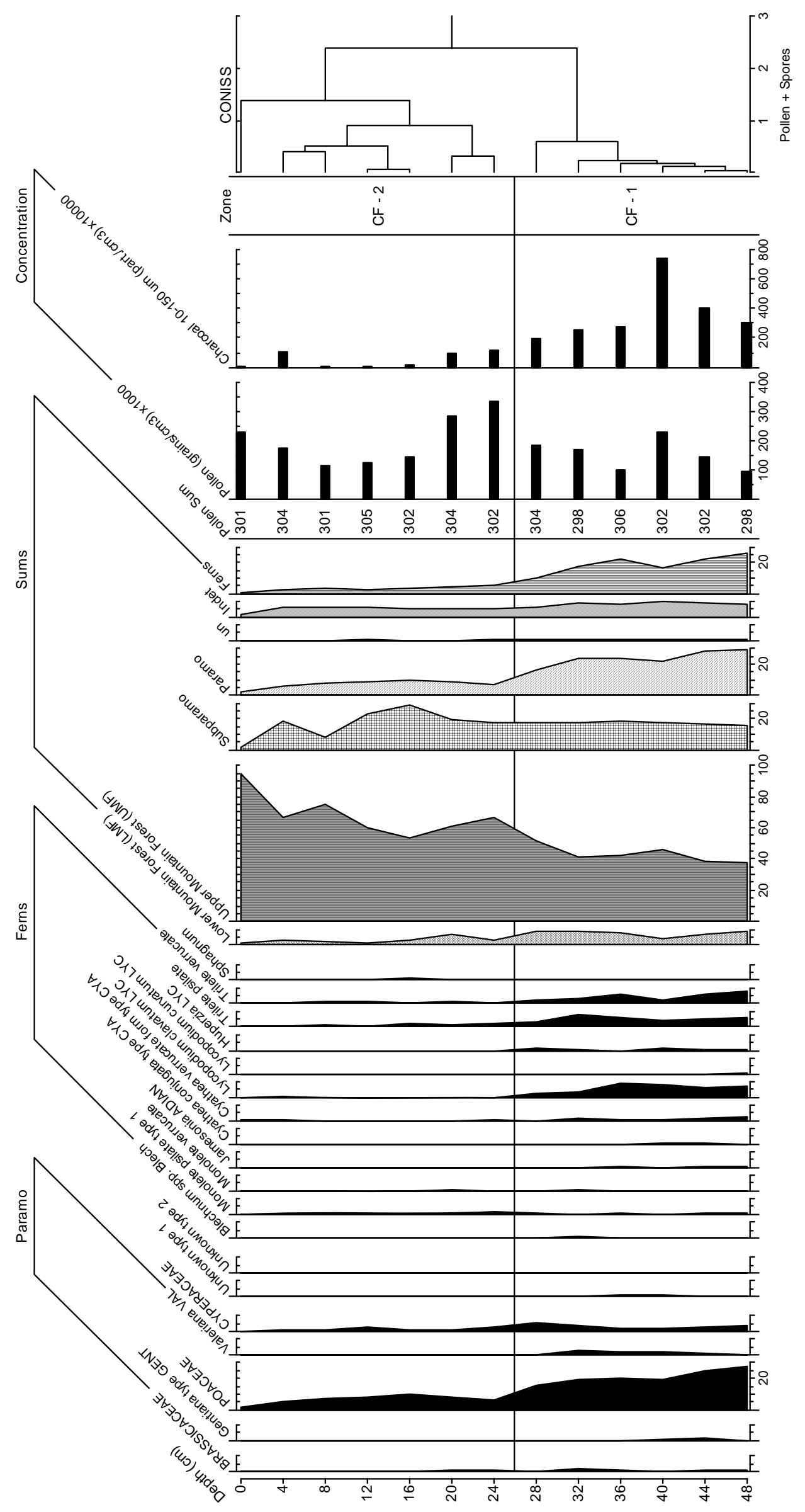

Complete record of Cocha Caranga forest (2) 


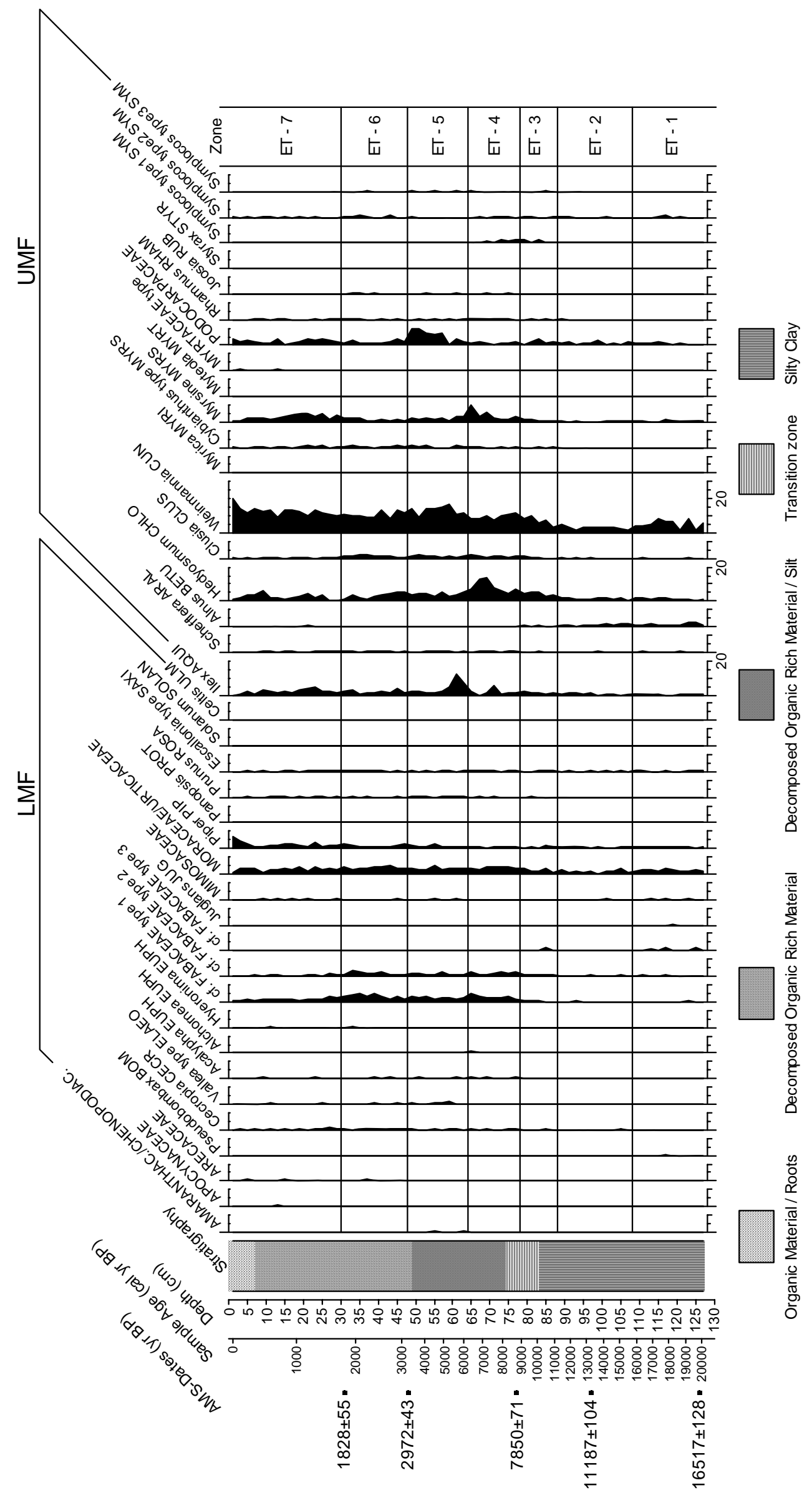

Complete record of the El Tiro-Pass (1) 


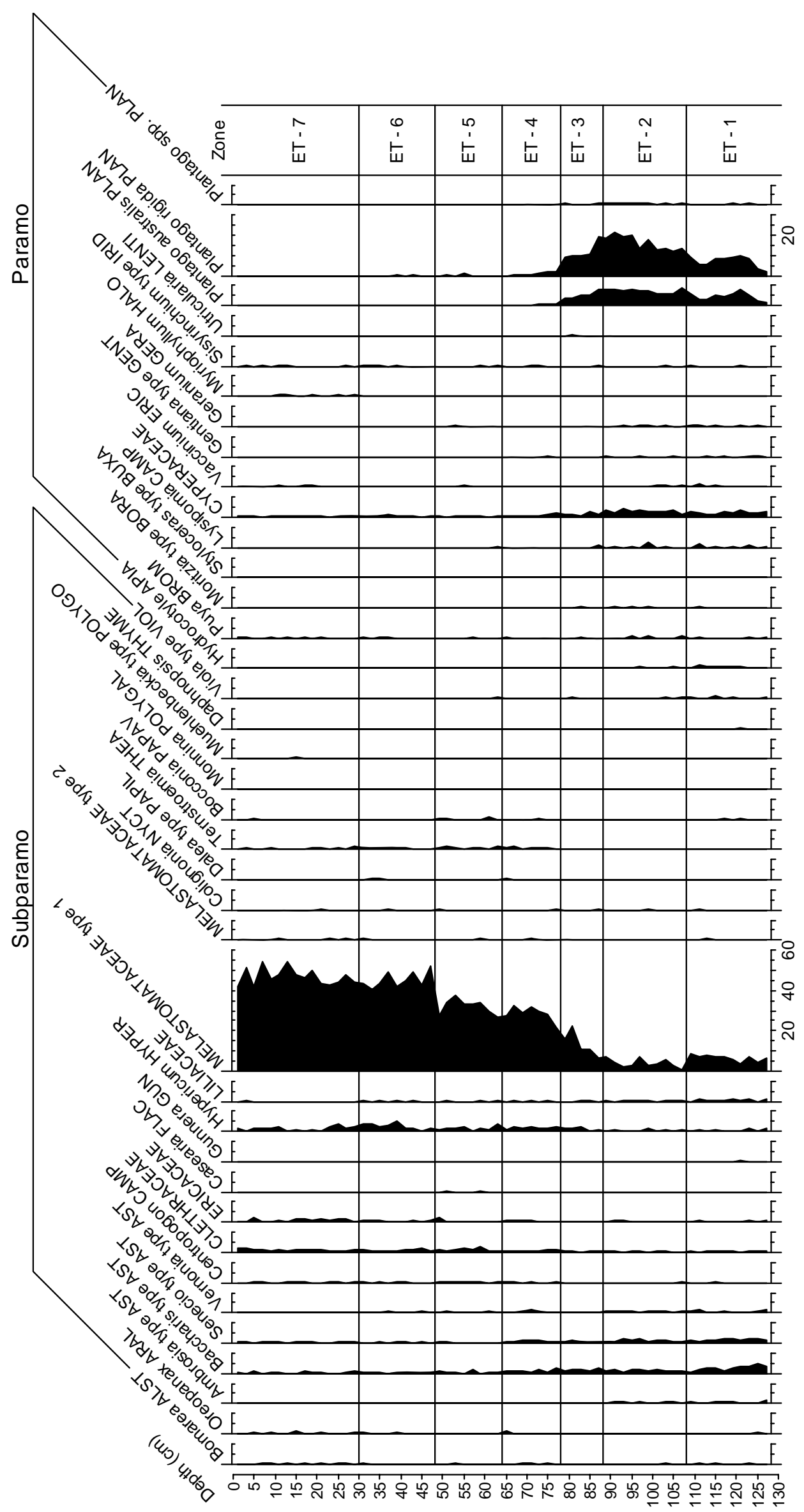

Complete record of the El Tiro-Pass (2) 


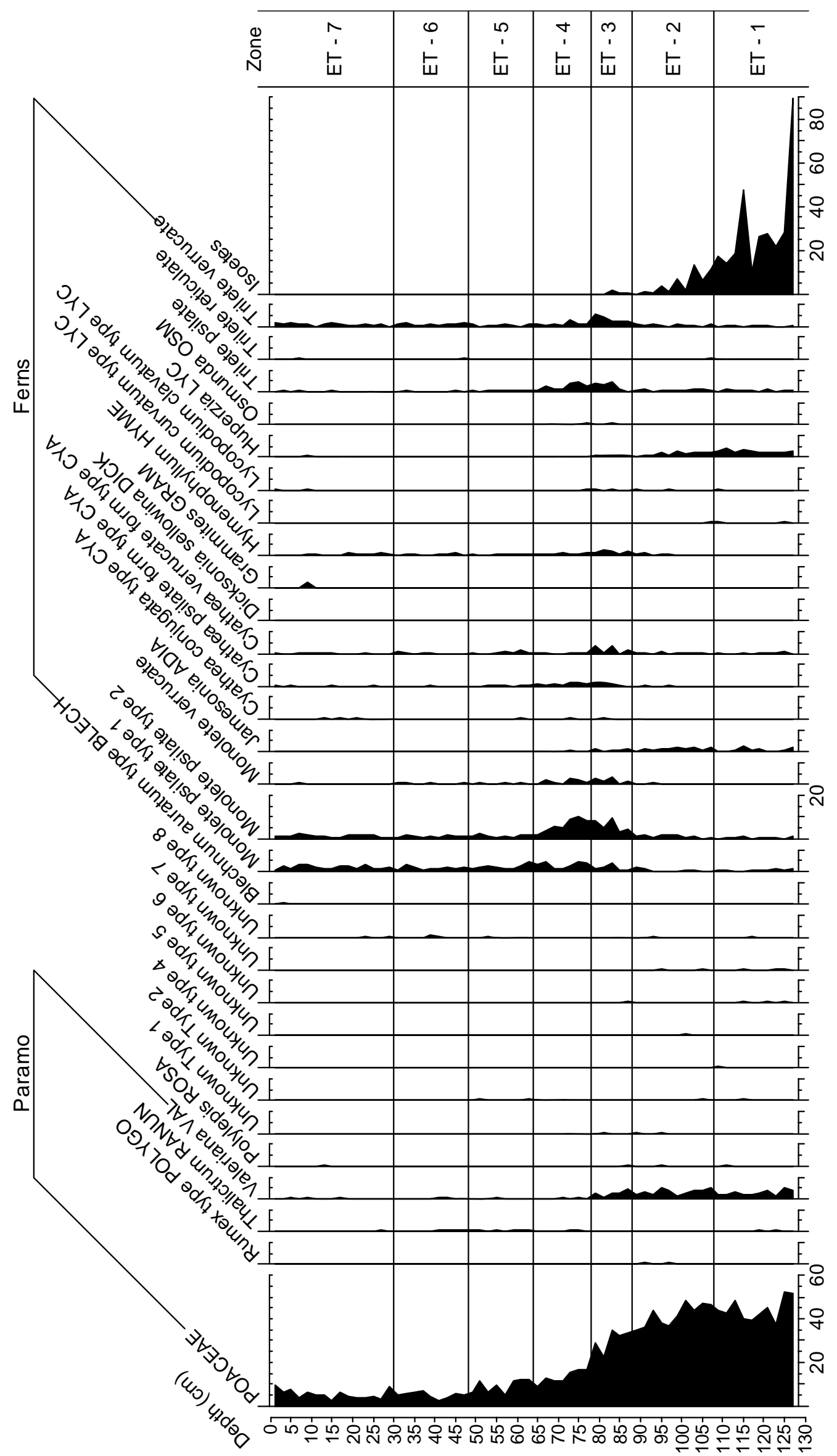

Complete record of the El Tiro-Pass (3) 


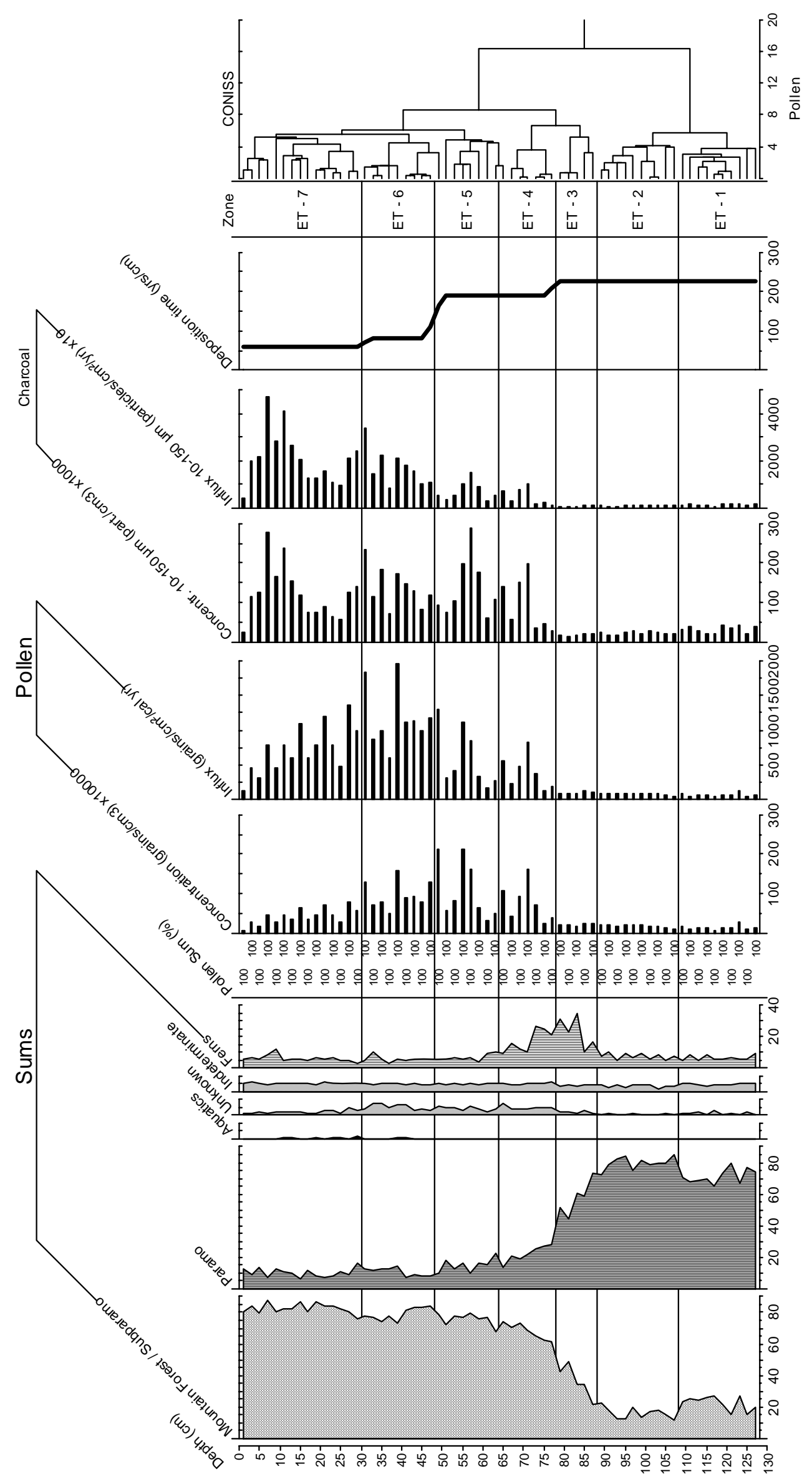

Complete record of the El Tiro-Pass (4) 